\title{
NeW ZEALAND LEARNING ENVIRONMENTS: THE ROLE OF DESIGN AND THE DESIGN PROCESS
}

\author{
BY
}

FATIMAH MOHAMMED ALSAIF

\begin{abstract}
A THESIS
SUBMITTED TO THE VICTORIA UNIVERSITY OF WELLINGTON IN FULFILMENT OF THE REQUIREMENTS FOR THE DEGREE OF DOCTOR OF PHILOSOPHY
\end{abstract}

VICTORIA UNIVERSITY OF WELLINGTON 2014 



\section{DEDICATION}

I would like to dedicate my thesis to my beloved little family; my husband Ali and children Alhassan and Hawraa. 


\section{ABSTRACT}

Learning environments are important spaces because these are where primary school children spend many hours. These environments can vary from single cell classrooms to modern open plan learning studios. As the design of these learning environments can affect the learning outcomes of students, their design and the design process behind them are important fields of investigation. Involving the users of learning environments in the design process is an important factor to be considered. Studies overseas stress the importance of involving teachers and students in the design process of learning environments. However, studies about learning environments in New Zealand show less consideration for the internal layout of classrooms and the involvement of users in their design process. Thus, this thesis studies and compares the design process behind learning environments in New Zealand with those overseas and the effect of this involvement on the design of primary school internal learning spaces, specifically classrooms. The aim of this thesis is create an understanding of the design

process behind primary school classroom learning environments in New Zealand.

To achieve the aim, this thesis undertakes five phases of study. The first phase is surveying primary school teachers and architects who design educational spaces, about the design and design process of learning environments in New Zealand. The survey results show that both teachers and 
architects support participatory design in schools and wish for more student user involvement. The second phase is a trial using social media to encourage more teacher and student participation in designing learning environments. Wordpress and Facebook groups were used for this experiment and teachers and students of primary schools in New Zealand were invited to participate. The trial result appears to indicate that social media does not work in encouraging students and teachers in thinking about the design of learning environments in general without having a specific project as a focus. The third phase is a workshop gathering five teachers and one architect to discuss the detail of the design process behind learning environments in New Zealand. The workshop result suggests that again participants support participatory design but suggest the need for guidance on how to do this, possibly from the Ministry of Education. The fourth phase is a case study of the early stages of a re-build project for Thorndon Primary School in Wellington city. The case study included interviews, focus groups, observations, and collecting documentation. The main conclusion from the case study is that all parties to the project were in support of participatory design but would have benefitted from guidance as the whole design process and user involvement in it is unclear. The last phase is also case studies but here the focus is on the design process for rearranging the internal layout of two classrooms in two primary schools in Wellington city. The case studies covered observing the involvement of students 
in the design process, some classroom and brainstorming sessions, and interviews with teachers. The main result of this phase is the observation that students enjoy working on the design of their own environments and that they are able and ready to work as part of such a design process.

The key conclusions of this thesis are that all parties involved in this research supported user participation in the design process, but in all the cases investigated there is almost no proper participatory design; students enjoy designing their learning environments and that enjoyment makes them belong and connect to these more; and proper preliminary guidelines for participatory design in learning environments could improve and encourage user involvement in designing learning environments in $\mathrm{New}$ Zealand. 


\section{ACKNOWLEDGMENTS}

I would like to express my gratitude to my primary supervisor, Prof. Brenda Vale, whose encouragement, guidance and support throughout this project enabled me to develop as a researcher and gain a much deeper understanding of the subject.

I owe my most sincere gratitude to all people who participated in this study including architects, school principals, teachers, and students. Without them there would be no research.

I would also like to acknowledge the Saudi Ministry of Higher Education for providing me with a scholarship and the financial support for this study.

I am also extremely grateful for my co-supervisor Christina Mackay for the help and support she provided throughout the whole research.

Finally, my love and gratitude goes to my beloved family members - my parents Naima and Mohammed, my siblings, and my husband Ali - for their support and endless love, that gave me strength during my studies, and the courage and determination to pursue my goals even further.

Fatimah Alsaif 


\section{TABLE OF CONTENTS}

CHAPTER 1: INTRODUCTION 20

$\begin{array}{ll}\text { 1.1 BACKGROUND TO THE STUDY } & 20\end{array}$

1.2 THE AIM OF THE STUDY 24

$\begin{array}{ll}1.3 & \text { OVERVIEW OF THE STUDY } \\ 26\end{array}$

CHAPTER 2: BACKGROUND TO THE DESIGN OF SCHOOLS AND

LEARNING ENVIRONMENTS $\quad 30$

$\begin{array}{lll}2.1 & \text { HISTORY OF SCHOOLS } & 31\end{array}$

2.2 DESIGN ELEMENTS OF LEARNING ENVIRONMENTS 52

2.3 THE EFFECT OF LEARNING ENVIRONMENT DESIGN ON TEACHING STYLES AND

$\begin{array}{ll}\text { LEARNING OUTCOMES } & 64\end{array}$

$\begin{array}{lll}2.4 & \text { CONCLUSIONS } & 71\end{array}$

CHAPTER 3: THE CLASSROOM DESIGN PROCESS

$\begin{array}{lll}3.1 & \text { PARTICIPATORY DESIGN } & 75\end{array}$

3.2 TEACHER INVOLVEMENT IN DESIGNING LEARNING ENVIRONMENTS

3.3 PARTICIPATION OF CHILDREN: 93

3.4 EXAMPLES OF PARTICIPATORY DESIGN IN LEARNING ENVIRONMENTS 118

$\begin{array}{lll}3.5 & \text { Post OCCUPANCY EVALUATIONS } & 124\end{array}$

$\begin{array}{lll}3.6 & \text { CONCLUSIONS } & 128\end{array}$ 
CHAPTER 4: DESIGNING LEARNING ENVIRONMENTS IN NEW ZEALAND 130

4.1 PRIZE-WINNING PRIMARY SCHOOLS IN NEW ZEALAND

4.2 MINISTRY OF EDUCATION WORK ON THE DESIGN OF LEARNING ENVIRONMENTS138

4.3 OTHER STUDIES OF LEARNING ENVIRONMENTS IN NEW ZEALAND 200

$\begin{array}{lll}4.4 & \text { CONCLUSIONS } & 206\end{array}$

CHAPTER 5: RESEARCH DESIGN 211

5.1 THE FRAMEWORK OF THE STUDY 212

5.2 RESEARCH QUESTION

5.3 RESEARCH SCOPE 216

$\begin{array}{llr}5.4 & \text { SELECTION OF METHODS } & 219\end{array}$

$\begin{array}{lll}5.5 & \text { SUMMARY } & 223\end{array}$

CHAPTER 6: PHASE ONE: SURVEY OF TEACHERS AND ARCHITECTS 225

6.1 SURVEY METHODS FOR PHASE ONE 226

6.2 TEACHERS' SURVEY FINDINGS AND ANALYSIS 236

6.3 ARCHITECTS' SURVEY RESULTS 266

6.4 COMPARISON OF TEACHERS' AND ARCHITECTS' SURVEYS 289

$\begin{array}{lll}6.5 & \text { CONCLUSIONS } & 294\end{array}$

CHAPTER 7: PHASE TWO, THREE, FOUR, AND FIVE. 297

7.1 PHASE TWO: USING SOCIAL MEDIA TO INVOLVE USERS IN THE DESIGN PROCESS 298

\begin{tabular}{ll}
7.2 & PHASE THREE: WORKSHOP \\
\hline 21
\end{tabular}

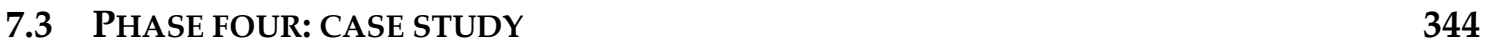

7.4 PHASE FIVE: INVOLVING USERS IN A CLASSROOM LAYOUT DESIGN PROCESS 385

$\begin{array}{lll}7.5 & \text { CONCLUSIONS } & 431\end{array}$

CHAPTER 8: DISCUSSIONS AND CONCLUSIONS

8.1 DISCUSSION OF RESEARCH FINDINGS 435

$\begin{array}{lll}8.2 & \text { CONCLUSIONS SUMMARY } & 454\end{array}$ 
APPENDICES 472

APPENDIX A: THE ETHICS APPROVAL FOR THIS PHD RESEARCH 472

APPENDIX B: TEACHERS PHASE ONE FOCUS GROUP 473

APPENDIX C: PHASE ONE ARCHITECTS FOCUS GROUP 478

APPENDIX D: PHASE ONE TEACHER'S SURVEY 481

APPENDIX E: PHASE ONE ARCHITECTS' SURVEY 506

APPENDIX F: PHASE THREE WORKSHOP FEEDBACK SHEET 525

APPENDIX G: PHASE FOUR QUESTIONS FOR THE ARCHITECT 526

APPENDIX H: PHASE FIVE QUESTIONS FOR TEACHERS 528

APPENDIX I: PHASE FIVE BRAINSTORMING QUESTIONS 529

APPENDIX J: PHASE FIVE FEEDBACK SHEETS 530 


\section{LIST OF FIGURES}

Figure 2-1: The one-room school layout (LLOYD, 2013). 34

Figure 2-2: The two-room school layout (Seaborne, 1971). 36

Figure 2-3: The traditional "cells and bells" classroom layout (Sachsse, 2003). 39

Figure 2-4: Central hall school layout, 1894 (Seaborne, 1971). 39

Figure 2-5: A school built in 1926 with verandas to the classrooms and quadrangles (Seaborne, 1971). 41

Figure 2-6: Finger plan school layout with corridors (Seaborne, 1971). 43

Figure 2-7: Learning studio layout (Nair E Fielding, 2007). 45

Figure 2-8: Small learning community layout (Nair E Fielding, 2007). 46

Figure 3-1: Sketches for the doorhandle designed with participation of the elderly (Demirbilek $\mathcal{E}$ Demirkan, 2004). 82

Figure 3-2: Sketches for multi-purpose shelves designed with participation of the elderly (Demirbilek $\mathcal{E}$ Demirkan, 2004).

Figure 3-3: Sketches for the door screen designed with participation of the elderly (Demirbilek $\mathcal{E}$

Demirkan, 2004).

Figure 3-4: Different trapezoidal table layouts to save space. 88

Figure 3-5: Horseshoe-shaped table arrangement. 88

Figure 3-6: Changing the layout from five rows of desks to three-sided seating 89

Figure 3-7: "Classroom Architect" tools to draw and furnish classroom floor plans. a screen shot from

"Classroom architect" (2008).

Figure 3-8: Methods for children's involvement in decision-making (Ministry of Social

Development, 2003). 103

Figure 3-9: The floor plan of the Inside Out project (Featherston, 2006). 123

Figure 4-1: The briefing and consultation process according to the "Best Practice in School Design"

Study. developed from sheerin \& Bruce (2004, pp. 146-148). 143

Figure 4-2: Student and teacher involvement in classroom design. 149

Figure 4-3: The types of classrooms within the 22 Ministry examples. 154

Figure 4-4: A partially furnished floor plan of the new entrants block at East Taieri School 154

Figure 4-5: The furniture in a single cell classroom, Parnell School. 155

Figure 4-6: The furniture in an open plan classroom, Koraunui School. 155

Figure 4-7: A Ministry example of good natural ventilation through high level windows. 165 
Figure 4-8: A Ministry example of good ventilation in learning environments through the ventilation grilles in the walls.

Figure 4-9: Individual settings in a modern learning environment: the individual nook with chairs._167

Figure 4-10: Setting for a large community gathering in a modern learning environment. 167

Figure 4-11: Modular seats in a modern learning environment. 168

Figure 4-12: Couches in a modern learning environment. 168

Figure 4-13: Chairs and computers in a modern learning environment 169

Figure 4-14: Computer use around A modern learning environment through the Wi-Fi connection._169

Figure 4-15: Computer labs in a modern learning environment supported by a number of laptops. _ 170

Figure 4-16: Cubbyholes as storage units in a modern learning environment 170

Figure 4-17: Personal lockers in a modern learning environment 171

Figure 4-18: Modern learning environments in Auckland Normal Intermediate 173

Figure 4-19: Modern learning environments in Woolston School 175

Figure 4-20: Modern learning environments in Breens Intermediate 176

Figure 4-21: The relationships in learning studios. developed from Babbage Architects and Ministry of

Education (2012). 179

Figure 4-22: The learning studios in Adventure School. (supplied by Ministry of Education privately).

Figure 4-23: The learning studios in Arthur Miller School (supplied by Ministry of Education privately).

Figure 4-24: The learning studios in Kilbirnie School (supplied by Ministry of Education privately). 181

Figure 4-25: The learning studios in Pongakawa School (supplied by Ministry of Education privately).

Figure 4-26: The learning studios in Freeville School (supplied by Ministry of Education privately). _182

Figure 4-27: analysis of the learning studios in Kilbirnie and Adventure Schools 189

Figure 4-28: the furniture layout for Kilbirnie School 190

Figure 4-29: The furniture layout for Adventure School 190

Figure 4-30: A learning studio in Kilbirnie School showing the transparency from the glazed door and windows between it and the shared area

Figure 4-31: Reading corner supported by beanbags and bookshelves and a table for learning studio group work in the Kilbirnie School shared area 195

Figure 4-32: A learning studio in Adventure School showing the use of desks and chairs 197 
Figure 4-33: The shared area in Adventure School with tables and seating for whole block gatherings and a whiteboard for teaching and learning in the shared area 198

Figure 5-1: The research problem components. 214

Figure 6-1: Types of learning spaces from teachers' survey 238

Figure 6-2: Participant responses to $Q 16$ in teachers' survey. 251

Figure 6-3: Participant responses to $Q 18$ in teachers' survey. 256

Figure 6-4: Participants responses to Q20 in teachers' survey. 260

Figure 6-5: Comparison of responses to teacher and student involvement from all participants and teachers who change their learning environment layouts. 264

Figure 6-6: Participant' responses to Q17 in architects' survey. 283

Figure 7-1: The structure of the blog "Designing my classroom" 307

Figure 7-2a: Student drawings in post 3 on the blog. 316

Figure 7-3: Questions asked during the workshop 325

Figure 7-4: A teacher's suggestion for creating a divider with storage units 334

Figure 7-5: The architect's suggestion for creating a divider with lockers 334

Figure 7-6: The architect's suggestion for creating rotatable partitions 335

Figure 7-7: An idea inspired by dots and boxes game. 338

Figure 7-8: Existing site plan of Thorndon School: Provided by Mackenzie and Higham Architecture 359 Figure 7-9: Proposed site plan of Thorndon School: Provided by Mackenzie and Higham Architecture 360 Figure 7-10: Proposed floor plan of Thorndon School. Provided by Mackenzie and Higham

Architecture 361

Figure 7-11: The library area display with the guidelines and participant comments 371

Figure 7-12: The music room display and participant comments: photographs Taken by Thorndon School principal 374

Figure 7-13: The outdoor areas display, questions for the participants, and participant comments 375

Figure 7-14: The exercise sheet created by the teacher, Te Aro Classroom. 394

Figure 7-15: Students' work in the exercise created by the teacher, Te Aro Classroom 395

Figure 7-16: Photographs of the existing layout, Te Aro Classroom 396

Figure 7-17: The existing layout, Te Aro Classroom 396

Figure 7-18: Photographs of the existing layout, Thorndon Classroom 398

Figure 7-19: The existing layout, Thorndon Classroom 399

Figure 7-20: The classroom layouts used in the brainstorming sessions. (A) is a traditional classroom. (B, $C, \mathcal{E} D)$ are classroom layouts with specialised zones 400 
Figure 7-21: The rules for the redesign exercise 406

Figure 7-22: Students in the workshop, Te Aro Classroom. 408

Figure 7-23: Written work, Te Aro Classroom. 409

Figure 7-24: Drawings, Te Aro Classroom. 411

Figure 7-25: The workshop, Thorndon Classroom. 413

Figure 7-26: Students' written work, Thorndon Classroom. 415

Figure 7-27: Students' drawings, Thorndon Classroom 416

Figure 7-28: The cardboard layout created at the final design stage, Te Aro Classroom 419

Figure 7-29: The final layout, Te Aro Classroom. 420

Figure 7-30: Photographs of the final layout, Te Aro Classroom 420

Figure 7-31: The cardboard layout created at the final design stage, Thorndon Classroom 422

Figure 7-32: The final layout, Thorndon Classroom 423

Figure 7-33: Photographs of the final layout, Thorndon Classroom 423 


\section{LIST OF TABLES}

Table 3-1: The different variables in participatory designs (Sanoff, 2011). 78

Table 3-2: Ways to involve children in the design process and decision-making. 103

Table 4-1: Information about the 22 prize winning primary schools in 2012 in New Zealand. 132

Table 4-2: Methods of Student involvement in the design process 149

Table 4-3: Methods of teacher involvement in the design process 150

Table 4-4: The examples provided by the Ministry for Modern learning environments (The chart is based on the information and pictures provided by the schools to the Ministry of Education. Schools were not visited) (N/A= Not Applicable, NM= Not Mentioned). 158

Table 5-1: The different phases and methods used in this study 221

Table 6-1: Questions inspired by the teacher focus group discussions 230

Table 6-2: Questions inspired by the architects focus group discussions

Table 6-3: Participant responses to Q9 in teachers' survey. 242

Table 6-4: Participant responses to Q10 in teachers' survey. 244

Table 6-5: Participant responses to Q11 in teachers' survey. 245

Table 6-6: Participant responses to Q13 in teachers' survey. 247

Table 6-7: Participant responses to Q16 in teachers' survey. 250

Table 6-8: Participant responses to Q17 in teachers' survey. 252

Table 6-9: Participant responses to Q18 in teachers' survey. 254

Table 6-10: Participant responses to Q19 in teachers' survey. 258

Table 6-11: Participant responses to Q20 in teachers' survey. 261

Table 6-12: Responses from people who change their classroom layout to teacher and student involvement in the design process. 264

Table 6-13: Participants responses to Q4 in architects' survey. 267

Table 6-14: Participants' responses to Q5 in architects' survey. 269

Table 6-15: Participants' responses to Q6 in architects' survey. 270

Table 6-16: Participant responses to $Q 7$ in architects' survey. 272

Table 6-17: Participant responses to $Q 9$ in architects' survey. 273

Table 6-18: Participant responses to Q10 in architects' survey. 275

Table 6-19: Participants responses to Q11 in architects' survey. 276

Table 6-20: Participant responses to Q17 in architects' survey. 282 
Table 6-21: Participants responses to Q18 in architects' survey.

Table 6-22: Participant responses to Q19 in architects' survey.

Table 6-23: Correlation to find out if architects who have completed more design projects are keener on involving students and teachers in the design process. 286

Table 6-24: Correlation to find out if the architects who use the Ministry guidelines are keener on involving students and teachers in the design process. 288

Table 6-25: The first correlation between architects' and teachers' surveys. 290

Table 6-26: The second correlation between architects' and teachers' surveys. 293

Table 7-1: The design process up to the time of the meeting with the Principal 353 


\section{CHAPTER 1: INTRODUCTION}

\subsection{BACKGROUND TO THE STUDY}

The educational years form a vital period in children's lives. Children spend several hours every weekday at their schools and most of this is spent in classrooms (Alsaif, 2011). Identifying the key factors that affect the learning and wellbeing of children in schools is very important. For this reason, there should be a solid focus on the interior design and settings of classrooms.

This PhD study is a continuation of a Master's study that culminated in a thesis entitled "Intelligence-Friendly Environments", aimed at investigating the interior design of primary school classrooms in Wellington City in relation to the educational theory of multiple intelligences. Multiple intelligence theory (MI) suggests that different types of intelligence affect the ability to learn and perform, and that educational strategies should be adjusted to each intelligence type (Stanford, 2003). The Master's study proposed that, in addition to changes in teaching strategies, MI themes could be incorporated into classrooms through their interior design and furniture settings. Such a move would support students with different learning preferences to learn more effectively (Alsaif, 2011).

In the first phase of the Master's study a group of settings that serve each type of MI intelligences was proposed. For example, spatial intelligence excels through activities like 
designing; dealing with colours, lines, shapes, forms, and spaces; and visualizing and building. For this intelligence, the study proposed settings such as a round table for group creative work or individual work, supported by a water supply (there could be a pottery wheel); an art area with tables and chairs (there could be one or two painting stands); and a building corner with movable, flexible, or buildable furniture, and building materials with a wide range of colours and shapes. Another example is bodily-kinesthetic intelligence, which engages learning through expressing thoughts and concepts or creating products through the use of the body, or a part of it. To encourage students that have this intelligence learning environments could contain some open space for creative movement. There could be special center for inventive hands (supplied with materials such as clay, timber and blocks). There also could be equipment that encourages various body movements such as a minitrampoline or juggling equipment for active students (Armstrong, 2009).

The second phase of the study involved four case studies in primary schools in Wellington City. The case studies were conducted in order to compare the proposed settings to those found in these primary school classrooms in New Zealand. The case studies revolved around four primary classrooms in four different schools, the four teachers of these classrooms, and 20 students (5 students selected randomly from each classroom). The case studies started 
with a one-day observation in each classroom noting the activities completed there, the settings used during these activities, and the number of students using these settings. The second part of the case studies was in two parts. The first involved interviewing students face to face and having them draw their dream classroom, and the second involved teachers completing a questionnaire. The final part was collecting physical evidence, including furniture and room dimensions, which produced a furnished floor plan for each classroom. The first main finding of this investigation was that most users have a very positive view of their classroom settings. The second finding was that MI theory was not supported strongly in the four classrooms. The conclusions indicated that the case study classroom settings mainly supported traditional views of intelligence and teaching, although applying MI theory to classroom designs could lead to more productive learning environments in New Zealand primary schools.

This earlier study of primary school classrooms suggested the need for a group of settings that could support a variety of teaching strategies. The results also indicated that these settings could improve learning environments. So having different settings or different furniture layouts in classrooms could be important for effective learning. This led to the current investigation into the design process and whether this could produce good or bad classroom layouts. Preliminary research was completed to investigate the 
design process behind primary school learning environments and the keys for achieving high quality learning environments. A number of studies discussed the importance of involving the users of learning environments in the process of designing these spaces, and this led directly to this current research. The basic information gathered from the literature indicated that there is insufficient information about the design process behind learning environments in New Zealand. Discussions about the involvement of users and the benefits of this involvement were barely touched upon. Further research was needed to form a clearer picture of the design process and user involvement in designing learning environments in New Zealand.

To establish the different stages of the New Zealand learning environments design process a preliminary investigation suggested that the Ministry of Education were a key player. A visit was arranged with the Ministry and the researcher met with people from the property management department, some of whom but not all were architects. They indicated their support to the research and suggested that all communication with them would go through one person from the Ministry people in the meeting. This led to a series of discussions about the design process of learning environments in New Zealand both face to face and via emails. The main indication from these was that the role of the Ministry of Education is complicated. They work with the architects to create the shell and also work with the 
schools to furnish what is inside that shell. They are the clients for any educational project, yet they do not meet with the architects except for the few times needed to discuss budget issues. This emphasised that the design process was a good area to research in order to try and figure out more about this complicated process and discover how a more participatory approach might be accommodated.

\subsection{The Aim OF THE STUdy}

The aim of this study is to create an understanding of the design process behind primary school classroom learning environments in New Zealand. As there was almost no background information related to the involvement of users in the design of learning spaces in New Zealand, this aim will be achieved through a series of investigations and studies to provide the required data. The aim is to study the internal layouts of classrooms in primary classrooms in $\mathrm{New}$ Zealand, as well as to focus on the design process of learning environments in New Zealand.

To achieve the aim, this study involved three major tasks. The first is gathering and evaluating the existing information and literature on the design process of learning environments, focusing on the involvement of users in this. It includes searching for data about designing learning spaces in general and the effect of having high quality learning space designs on the learning outcomes. The second task is to collect existing information about learning environments in New Zealand, again with a stress on the 
design process and user involvement. The third task is to investigate further the design process of learning environments in New Zealand through engagement with architects, teachers and students.

A first step is to discover whether the internal layouts in New Zealand primary school classrooms are sufficient or not. This will include finding out whether there are problems in the furniture arrangements, finding information about how classroom layouts are achieved and who makes the decisions, and finding ways of involving teachers and students in both the classroom layout and the design process behind new and refurbished school buildings. The study has been broken down into five phases to cover the necessary investigation. The first phase consists of surveys and focus groups involving teachers and architects through which to collect basic information about the design and design process of learning environments in New Zealand. The second phase is a trial of a social media approach to encourage teachers and students to be more involved in the design process. The third phase is a workshop with teachers and architects to discuss the findings of the first two phases and investigate further how users could be more involved in the design process of learning environments. The fourth phase is a case study looking at the design process behind a renovation project in a primary school in Wellington City. The final phase is a case study of the design process of 
changing the internal layout of two classrooms in two primary schools in Wellington City.

Achieving the aim of the study may not immediately change anything in the design process of learning environments but the information gathered can be a base for other studies about this, especially given the current lack of such studies in New Zealand.

\subsection{OverviEW OF THE STUDY}

After discussing the background, aim and overview of the thesis in the introductory chapter, the thesis is divided into two parts. The first part (chapters 2, 3, and 4) is a literature review of the design and design process of classrooms and learning environments in New Zealand and overseas. The second part (Chapters 5, 6, 7, and 8) presents the research design for the five phases of the investigation, the findings, and discussion of the results of the phases.

Chapter two provides background material on learning environments and the relationship between learning environments and learning outcomes. It includes historical descriptions of the progress of classroom design from the one-class schoolroom to the latest designs for learning studios and suites. This chapter also contains a discussion about the design of learning environments in terms of the classroom interior, classroom furniture, and quality of learning spaces. Chapter 3 focuses on the involvment of users in the design process of learning environments. It defines and discusses participatory design in general, with 
some examples of such design. It describes how some teachers have been involved in the design process of learning environments. Chapter 3 has a section about children's involvement in decsion-making in general and in the design of learning environments specifically. Chapter 4 gives information about the design and design process in schools and classrooms of New Zealand. It discusses the infornation provided by the Ministry of Education, including studies by the Ministry, their examples and guidelines for modern learning environments, and the guidelines for and review of a pilot project completed by the Minstry for learning studios. This chapter also discusses information on some prize-winning schools in New Zealand and other local studies about learning environments.

After collecting information relating to learning environments and the design process in New Zealand and overseas, a framework was needed to define the gaps in knowledge and start the research. Chapter 5 discusses the framework of this PhD study. It focuses on defining the problems and questions of the research and how these problems and questions could be answered. It also suggests why a group of studies was created in order to answer the research question. These studies are discussed in detail in chapters 6 and 7. Chapter 6 focuses only on the first phase concerning the two surveys of teachers and architects that were established to investigate the design process and the design of learning environments in New Zealand. This 
chapter explains the survey methods used for the first phase, including the preparation for the surveys, their aim, the target sample, and how and why the questions were developed. The chapter also provides the findings of the two surveys, including a brief discussion after each group of questions. There is a comparison of the results of the surveys of the teachers and architects. The results of this first phase helped in designing the other phases of the research.

In chapter 7 , the other four phases are discussed in detail. The second phase is an attempt to use social media to encourage teachers and students to be more involved in the design process. In this phase, available literature about using social media in participatory design is discussed. The third phase is a workshop gathering teachers and architects together to discuss the design process of learning environments. The fourth phase is a case study of the design process behind a renovation project in Thorndon Primary School in Wellington City. This includes some background material about Thorndon School and its buildings.

The last phase is also a participatory design case study, but this time is about changing the internal layouts of two classrooms in two schools (Thorndon School and Te Aro School) in Wellington City. In this chapter, each section outlines the aim of the particular phase, the methods used to complete the phase, findings, and discussion of the results. In the findings sections in chapters 6 and 7, there are brief discussions to relate the findings to the literature gathered 
in chapters 2, 3, and 4. Finally, Chapter 8 discusses the research findings and overall conclusions stemming from the study. Suggestions for possible future research conclude the thesis.

All photographs without the sources given were taken by the researcher during the course of the research. 


\section{CHAPTER 2: BACKGROUND TO THE DESIGN \\ OF SCHOOLS AND LEARNING ENVIRONMENTS}

As discussed in chapter 1, this study aims to investigate the design process behind primary school learning environments in New Zealand. To achieve this aim a first step is to examine the existing literature about designing learning environments and the general history behind these designs. This chapter focuses on exploring the history of schools and learning environments in various countries in order to form a base from which to examine learning environments in New Zealand.

This chapter is divided into three main parts. The first, with its two subsections briefly examines the history of schools. The first subsection discusses the development of learning environment layouts from the one-schoolroom design to the latest designs for learning studios. It includes historical information about building design elements inside learning environments. The second subsection examines the progress of elements other than those involved in the building layout. The second part of this chapter, again with two subsections, explores design elements within learning environments, including furniture and furnishing the learning spaces. The third part of this chapter looks at the relationship between having high quality learning environments, student learning 
outcomes and instructional teaching styles. After each part of this chapter a discussion is included to argue the findings of the literature discussed in the chapter in terms of the scope of the PhD research.

The studies from overseas discussed in this chapter and chapter 3 were included because of their relevance to the research, and the fact that no such studies exist for New Zealand, as discussed in more detail in chapter 4 .

\subsection{History OF SCHOOLS}

This section discusses the history of school buildings, from the first school structures to the recent learning studios designed in both Europe (especially Great Britain) and the US'. Some information is not specific to one country or region. As the aim of this section is to understand the history of schools and how the learning environments reached the current layouts used all over the world. To achieve this aim, the research has drawn on the book by Seaborne (1971) "Primary school design", which remains a comprehensive guide to the history of primary schools. The following two subsections describe the historical development of school buildings and their environmental elements.

\subsubsection{Development OF SCHOOL BUILDings}

This section discusses the different models of schools and classrooms found in history. Each section contains information about how certain models have appeared and alterations to the furniture layout that have occurred in the same period. 


\subsubsection{EARLY EDUCATIONAL ENVIRONMENTS}

The educational concept of gathering students in one location for learning existed in ancient Greece, Rome, India, and China. However, the founding of the primary education system in Europe is acknowledged to have started in $425 \mathrm{AD}$ (Bentley \& Ziegler, 2011). The real development in primary education came with the industrial revolution in the later part of the eighteenth century and the need to have some form of child care so both parents could work in the mills and factories. Often, however, such schools were set up in the name of philanthropy, as with Robert Owens' 1817 Infants School in New Lanark, Scotland (Donnachie, 2000). It was these pioneering developments that led to more general education of children and the need for school buildings.

Just before the nineteenth century, American research and studies focused on the need for standard school buildings (Baker, 2012). Until the construction of these, classes normally took place in a room attached to a residence or in the teacher's home in Europe, while in the United States (US), teaching occurred in many places, such as church basements and the living rooms of private homes. There were also some purpose built school buildings in the US (Chalet \& Guttmann, 2008).

The one-room plan was the first model that appeared for schools. It appeared after mass elementary education was 
enacted in the early nineteenth century in Great Britain (Seaborne, 1971). The one-room school also appeared in the US at about the same time (Baker, 2012). The one-room school originally consisted of a large room with one teacher or "assistant master" (Figure 2-1). The floor space per child was between six and seven square feet $\left(0.6-0.7 \mathrm{~m}^{2} /\right.$ child $)$. In the American Lancaster plan for the one-room school, children were seated at long desks or benches facing the wall, in front of which the master would stand and teach. There were aisles at the sides of these desks. The American Lancastrian plans were also used in Britain but with groups of moveable benches that were clustered to represent the different classes (Seaborne, 1971). Another model for the standard classroom in America in the early nineteenth century was drawn by Horace Mann, an early educational activist, who designed a classroom with rows of desks and windows on two sides of the room, in what became known as the factory-model. The factory model was another version of the one-room school (Baker, 2012). In Europe, this model was originally developed in Prussia in 1716 as part of a regimented schooling system. It was designed to produce the perfect citizens who would obey orders and not think for themselves. With this model, students and teachers became constrained. They could not control anything in their environments and were forced to use and obey what they were given (Meshchaninov, 2012). 
Later, many designs were introduced that were a step up from the single schoolroom. One was the gallery style, which consisted of a stepped floor on which students sat. This style was mainly for oral lessons given by the master and for infant schools. Separation between classes inside the schoolroom also was introduced, using curtains between side-to-side classes in one room. Smaller groups of children were taught in rotation. Each class, formed by the dividing curtains was occupied by a group of children and a teacher. When the master or teacher wished to join the classes together for joint instruction, the curtains were pulled back to create one large space (Seaborne, 1971). Figure 2-2 show how the curtains were used in one of the school models.

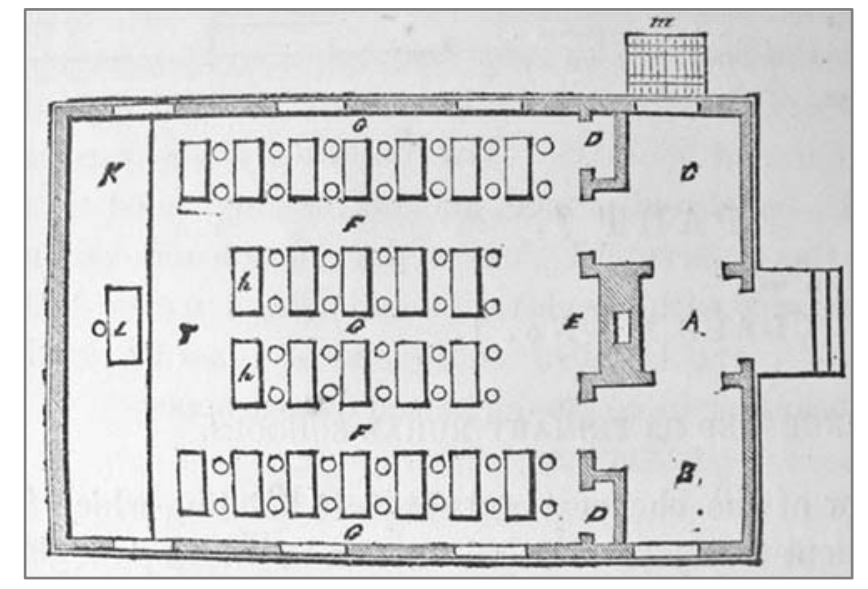

FIGURE 2-1: THE ONE-ROOM SCHOOL LAYOUT (LLOYD, 2013).

The two-room school, another model developed from the one-room school, was suggested by a committee of the Council on Education in England in 1851. It consisted of one room attached to the large schoolroom (Figure 2-2). Usually, 
there was a gallery attached to the two-room school for other uses, such as teaching infants (Seaborne, 1971). There was also a three-room school for primary school aged children that became common after 1856. The classes contained groups of all ages between 6 and 12 years old. Different teaching activities were completed in different classes. For example, one teacher could complete oral listens while another teacher gave writing listens, and a third teacher gave exercises for reading (Hadow, 1931).

Because of the industrial growth in some villages, some schools needed extensions to the models developed from the one-room model. For example, in 1873 when a village school needed extending two new classrooms were added to the original building and used for different activities. The original schoolroom was converted to a staffroom and secretary's room (Seaborne, 1971). 


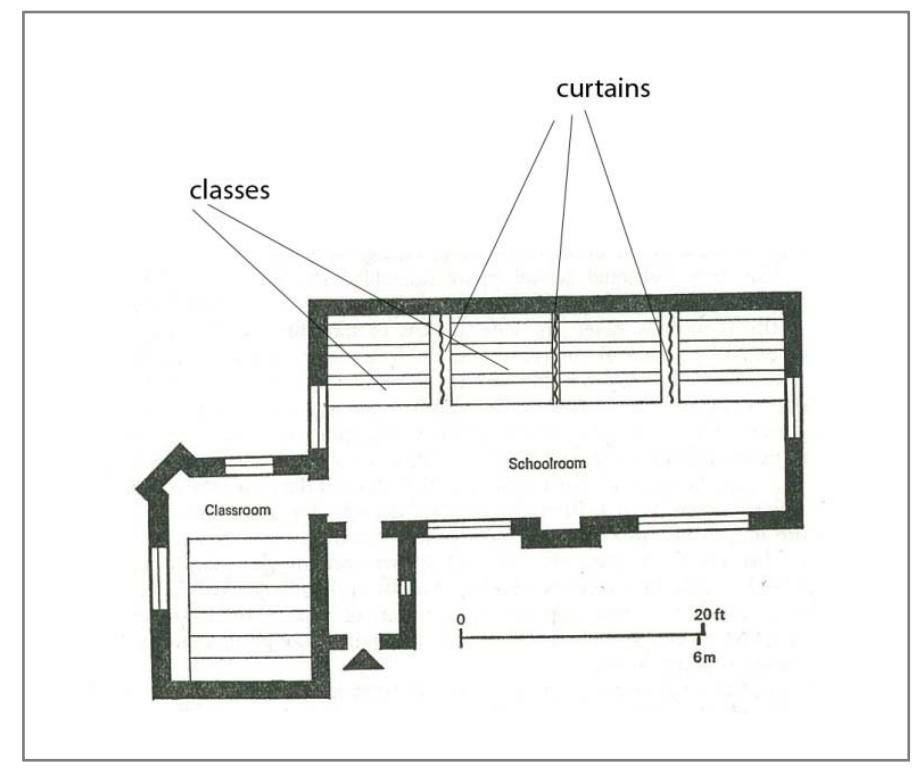

Figure 2-2: The tWo-room SCHOOL Layout (SEABorne, 1971).

\subsubsection{OPEN AIR CLASSROOMS AND THE \\ INTRODUCTION OF ART AND SCIENCE IN SCHOOLS}

In the $1860 \mathrm{~s}$ in the UK there were minimum acceptable standards for schools. These standards were that schools should have well-ventilated classrooms (at least one classroom), decent offices, a good master's house, a grass playground, and a healthy, accessible site (Seaborne \& Lowe, 1977). Thus, in 1880 and because of the introduction of compulsory education in Britain, open-air classrooms were introduced and the size of classrooms was reduced. After science and art were introduced into the curriculum in the late nineteenth century, there were other changes in school designs in Britain. There was a need for chemical laboratories and lecture rooms in schools for older children. The schools became a building of several rooms that has 
different functions such as classrooms and laboratories. In 1872, the Department of Science and Art controlled designs for schools as they were in charge of the budget (Seaborne \& Lowe, 1977). Schools built in the nineteenth century had furniture and equipment that gave teachers and students more space for different methods of teaching and activities such as physical exercise, whereas in older designs the schools were overcrowded and there was no opportunity for different activities (Seaborne, 1971).

In the last decades of the 19th and early decades of the 20th century, the schools in the US were built to accommodate as many students as possible using the factory-model of Horace Mann. Classroom space was maximized for more students (Baker, 2012). In this same period two major changes affected school building design:

1. Universal compulsory elementary education from the ages of 5 to 12, which required that schools accommodate larger numbers of children.

2. Less than half of the teaching staff was certified, leaving the rest of the staff as trainees. This encouraged keeping the one-schoolroom plan with groups of classes so the headmaster could keep a close eye on the trainee teachers. However, elementary school staff was left to teach classes in separate rooms (Seaborne, 1971).

\subsubsection{THE TRADITIONAL FORD AND CENTRAL} HALL MODELS

The traditional Ford, or Cells and Bells, model emerged as a result of the need for more schools in the twentieth century. 
The design of the classroom is a rectangular space with rows of desks and chairs for all students learning in that room. The teacher's desk is placed in front of the classroom with a blackboard behind on the front wall of the room (Figure 2-3) (Nair \& Fielding, 2007). The trend was to design a group of classrooms located on both sides of a central corridor. In some schools, the design ended up with a central hall instead of the corridor, leading to what was called the "centre-hall plan" (Figure 2-4). The hall was used for teaching two classes combined. The walls that separated classrooms from the hall were partially glazed to let the head of school see what was happening inside the classrooms (Seaborne, 1971, p. 27). Beginning around 1900 in Britain, teachers covered some of the glazed walls with sheets of paper to give them some privacy. The floor remained level in the middle nineteenth century, but when classrooms became bigger for larger numbers of children, the stepped floor re-appeared. There was also a replacement of the long desks at which children sat (Figure 2-3) with "dual desks" to give more space for teachers to move around. The central hall plan was normally in the form of a single three-storey building, with infants on the ground, girls on the first, and boys on the second floor (Seaborne 1971). 


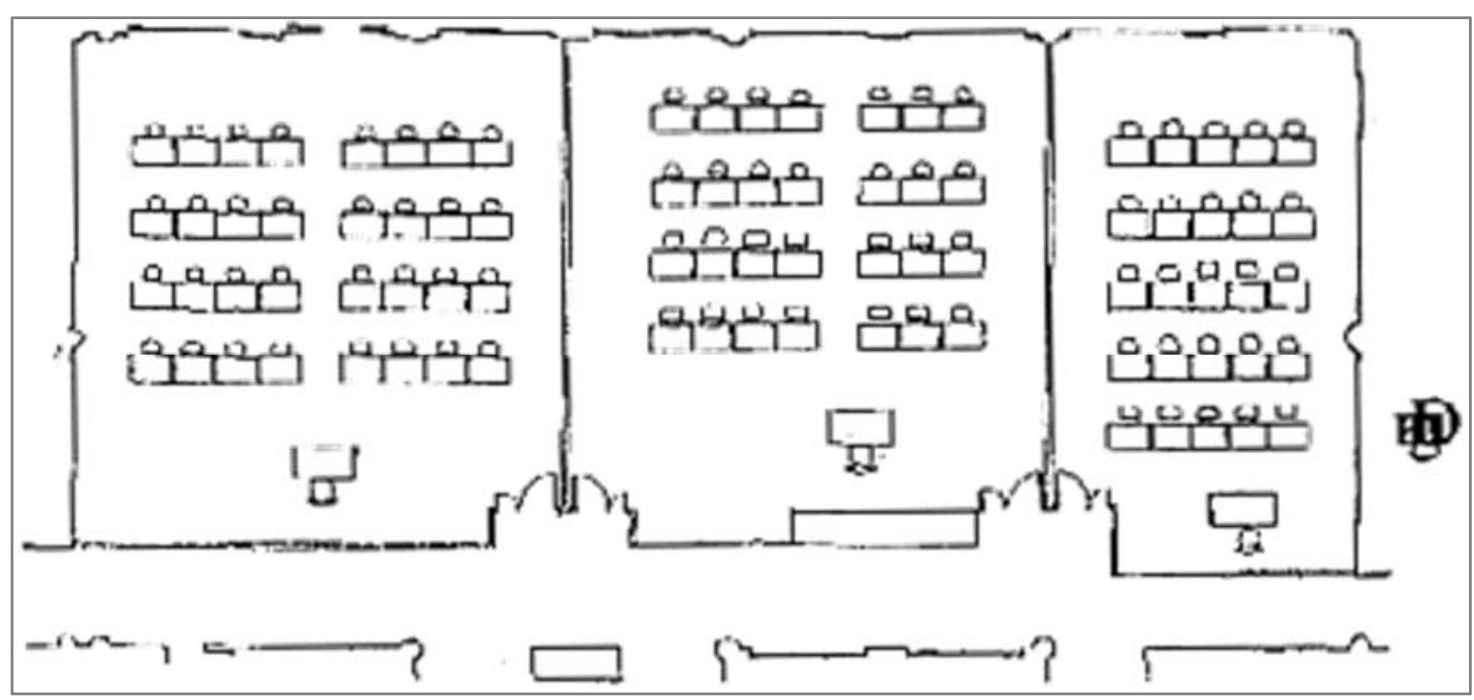

Figure 2-3: THE TRADitional “Cells AND Bells" ClAsSRoom LAYOUT (SACHSSE, 2003).

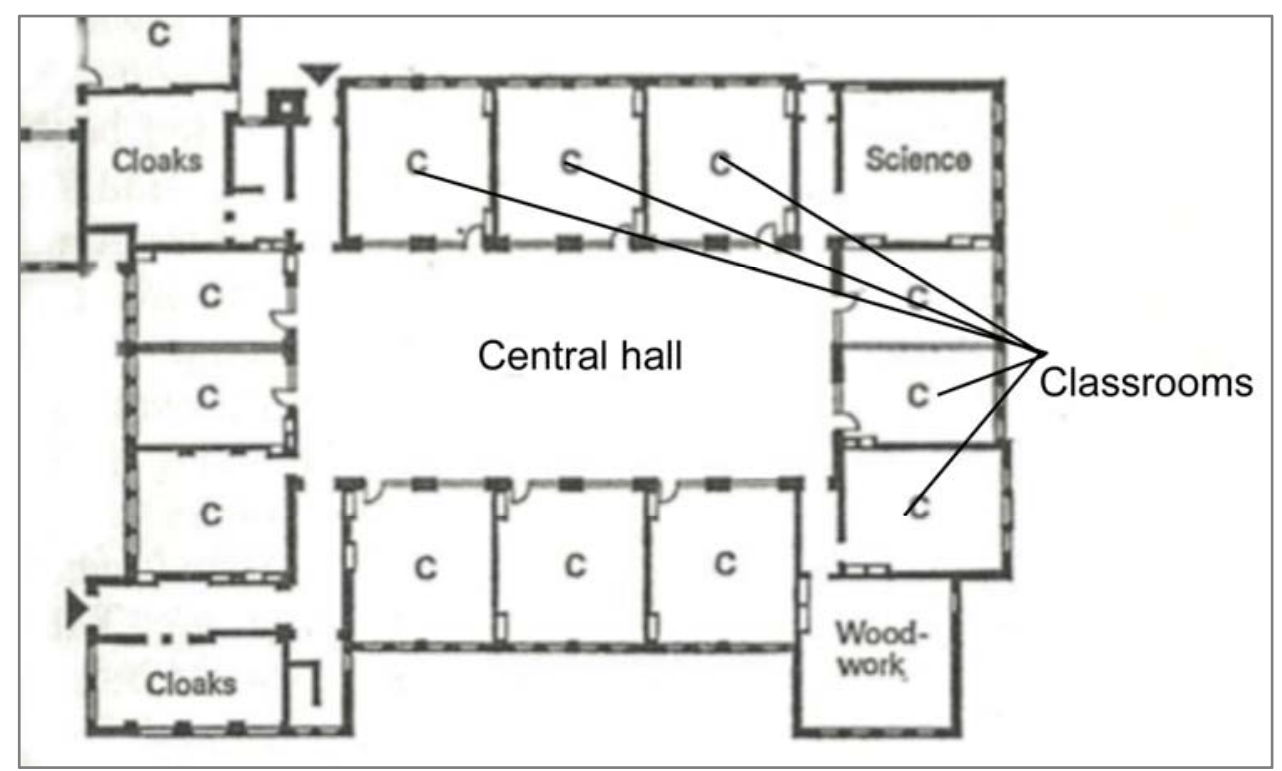

Figure 2-4: Central hall SCHOOl Layout, 1894 (SEAborne, 1971). 


\subsubsection{OPEN AIR SCHOOLS}

The halls in central hall model were further developed becoming open to the air for more ventilation, light and outdoor learning, thus creating the open-air model. The first open-air school in Europe was established in 1904 near Berlin and consisted of prefabricated huts and shelters without walls, although teaching also happened outside (Steadman, 2014). In 1907, after the attention given by parliamentarian Sir John Gorst (1906) to such schools, writing about them in his book The Children of the Nation, open-air schools started to appear in England, especially after powerful criticism of the central hall plan that stated it needed proper ventilation and natural lighting (Seaborne \& Lowe, 1977). However, the central hall in schools was seen as essential for encouraging the development of community spirit, and for physical exercise, and musical activities (Seaborne, 1971). Despite this, in 1930 in the US, many schools were built according to the "open air school" plan. The name came from the design of the original school near Berlin, which strongly emphasised air, light, and outdoor learning. In 1935, American educator Holly had written critically of the fact the learning process in these open-air schools was still mainly dependent on sitting at a desk. He suggested more active ways of learning and interactive working instead of only studying textbooks (Baker, 2012). 


\subsubsection{VERANDA SCHOOL MODEL}

Shortly before the First World War (WWI), the veranda school idea appeared, was developed and spread widely after WWI. The main idea of the veranda school is to separate classrooms from the hall. Classrooms could be arranged in rows with glazed folding doors that opened to the veranda. The verandas were also provided with highlevel windows to provide proper cross ventilation for classrooms when the folding doors were closed. These verandas offered access for classroom users to a space sheltered from rain and wind for outdoor teaching. The quadrangle plan was a veranda plan, replacing the closed hall with an open quadrangle with the classrooms looking in towards it (Figure 2-5) (Seaborne, 1971).

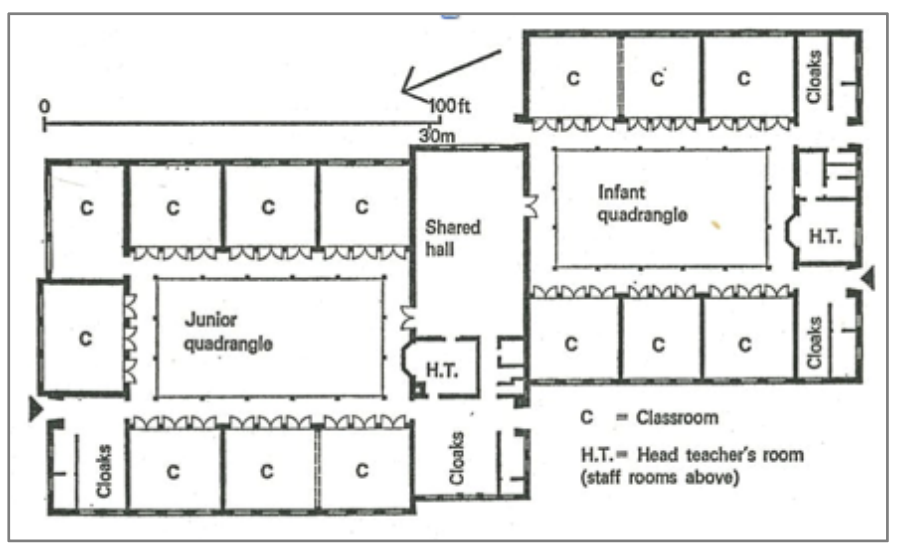

FigURE 2-5: A SCHOOL BUILT IN 1926 WITH VERANDAS TO THE CLASSROOMS AND QUADRANGLES (SEABORNE, 1971).

In 1931, the Hadow Report discussed organizing group work as well as individual work inside each classroom. With the introduction of group work, the teacher's role became 
more one of an advisor or consultant. In some schools, the layout of the furniture changed to suit group work teaching. Desks and chairs were arranged in groups instead of rows facing the black/white board. However, a study on school floor plans during the inter-war period revealed that many recommendations about group work and informal teaching methods remained theoretical except in nursery and some infant schools (Seaborne, 1971).

\subsubsection{THE CORRIDOR SCHOOL MODEL AND THE RE-APPEARANCE OF THE CENTRAL HALL PLAN}

Schools built before and after the Second World War (WWII) in the UK considered the need for good lighting and ventilation. Many schools built immediately before and after WWII were luxurious, with corridor or "finger plans" (Figure 2-6). They included corridor space, cloakrooms, playgrounds, and playing fields, in addition to the classrooms. The plan is generally an arrangement of a central hall and administration rooms, and corridors leading to a cluster of classrooms. After a few years, to reduce costs, the total floor area was reduced, the hall and dining areas were combined, access to some classrooms was through other classrooms, and the corridor area was added to classroom spaces to provide a larger teaching area. However, the extra space in classrooms was mainly used for circulation when other classes were passing through to access their classrooms. The only circulation area needed 
was between classrooms and the hall, which led to the reappearance of the central hall plan. In the 1950s, the architectural move to reduce circulation in school buildings started and continued into the 1960s. In some primary schools, in order to reduce circulation, the relationships between classrooms and between classrooms and the hall became very close. As a result, compact plans appeared. This later central hall plan gave the closest possible relationship between the hall and classrooms, but there were many problems with lighting, ventilation and sound isolation. In the 1950s and 1960s, classrooms were grouped around the hall (Seaborne, 1971). Meanwhile in the US, after WWII, new schools were built in modern styles with one-storey, flatroofed structures, and a mix of either glass and metal window wall systems or brick and concrete wall systems (Baker, 2012).

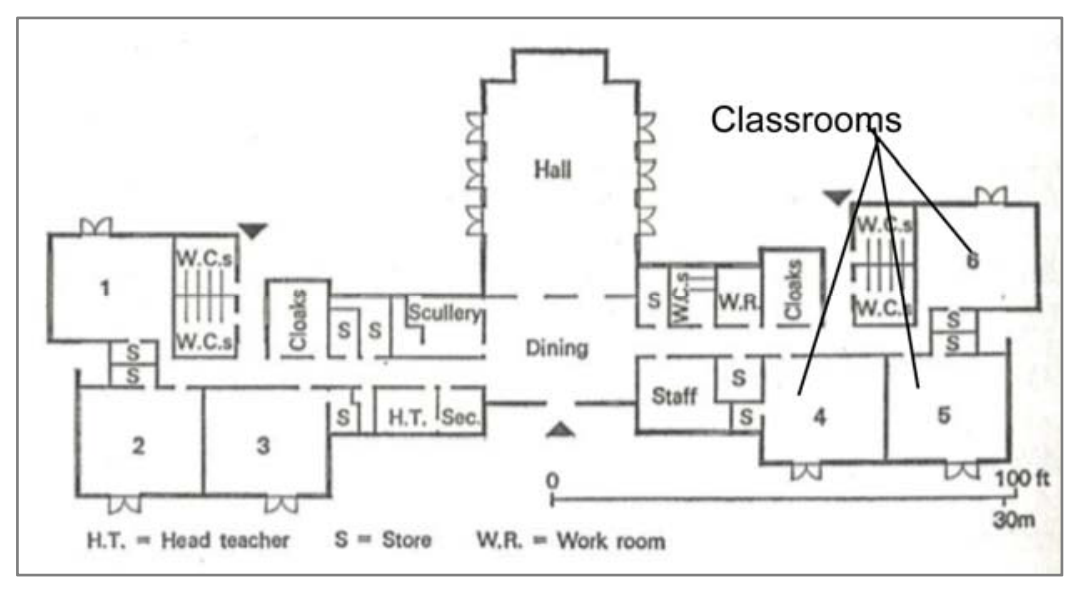

FIGURE 2-6: FINGER PLAN SCHOOL LAYOUT WITH CORRIDORS (SEABORNe, 1971). 


\subsubsection{OPEN PLAN CLASSROOMS}

Some educational views emphasised breaking out of the classroom areas and creating other teaching spaces. This tendency led to designing open-plan or studio-based schools. As a result of architectural and educational views, compact open-plan designs appeared. The extreme openplan idea was slow to be accepted by schools. In the 1960s, schools were designed on the "semi-open" principle, which included shared teaching spaces in addition to the traditional separated classrooms, as some teachers were not entirely happy working in semi-open or open-plan schools (Seaborne, 1971).

The open-plan model in schools appeared in the 1970s (Shield et al., 2010), although it had been experimented with as early as the late 1800s by educators who supported the child-centred approach in education, and by the late 20th century it had become popular (Nair \& Fielding, 2007). The aim of the studio-based model was to focus on the interests and motivations of students through active learning, learning by doing, and having an improved curriculum. In this model, teachers would come to know more about their students through greater and more student-focused communication between teachers and students (Lackney, 1999). The open-plan model, including the plan that became known as the learning studio, gave the classroom more flexibility. Each classroom or learning studio was a space 
that integrated a number of different learning activities (Figure 2-7) (Nair \& Fielding, 2007).

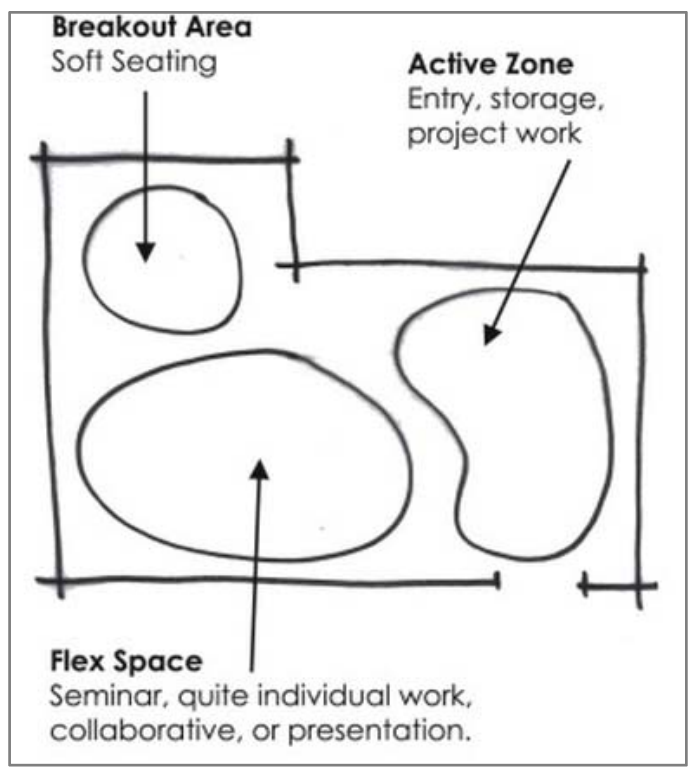

FiguRE 2-7: LeARNiNg STUdio LAYOUT (NAIR \& FieldiNG, 2007).

\subsubsection{PORTABLE CLASSROOMS}

In the 1980s, portable classrooms were installed in schools in the US, although by the late 1980s and 1990s, problems with these were emerging, the main one being that the portable classrooms were not as temporary as they were meant to be. Other problems were related to their adequacy for purpose and the quality of their indoor environments, as the air quality was very poor in them (Baker, 2012). However, most portable classrooms were cellular, going against the new initiatives in more flexible and open learning environments. 


\subsubsection{9}

SMALL LEARNING SOCIETY

One of the latest models for learning environments is the small learning society. This mainly appeared in US secondary schools under many names such as "houses", "schools within schools" and "charter schools". Small learning societies first appeared in the 1960s and become known as "small learning communities" after the 1990s (Oxley, 2004). The small learning community was a combination of the finger plan and the learning studio model. It was a multipurpose space that supported selfgoverning and cooperative learning. Small learning communities often had their own science lab, teacher workplace and other amenities (Figure 2-8) (Nair \& Fielding, 2007). This model aided in enhancing student achievements (Oxley, 2004), although it does not yet apply to primary schools, which are the focus of this study.

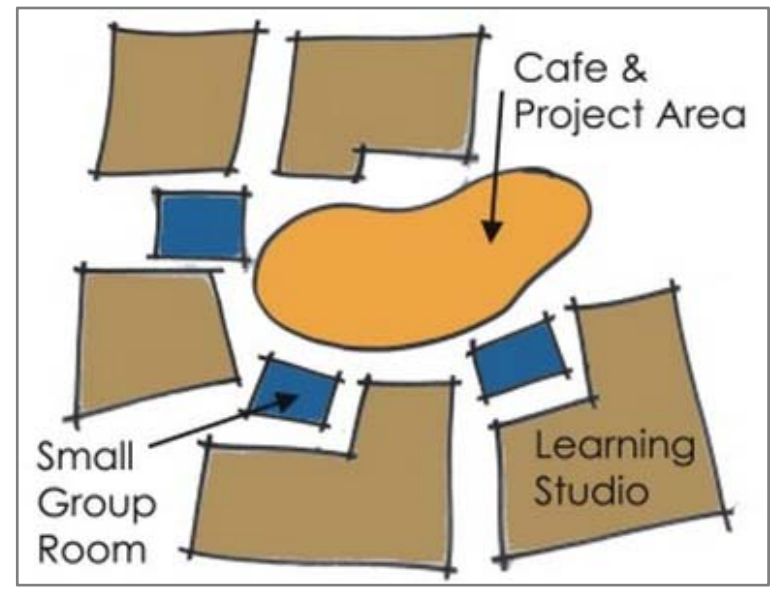

FigURE 2-8: SMALl LEARNING COMMUNITY LAYOUT (NAIR \& FIELDING, 2007). 


\subsubsection{THE ADVISORY MODEL}

By the end of the twentieth century the latest model, the advisory model, had emerged (Nair \& Fielding, 2007). The advisory model was also mainly found in secondary schools and it involved gathering a team of teachers with small groups of students, normally 8-15, for constant academic provision and guidance in a suitable place, such as a café or studio. Teachers met their students several times every week to provide the help they needed in ways that ranged from discussions of academic and social matters to arrangements for college and improving skills, and adolescent development issues and concerns (Tocci et al., 2005). Unlike other learning environment models that promoted a linear learning process, the advisory model was a model that required some interaction between the teachers and students (Nair \& Fielding, 2007).

\subsubsection{SPECIALISED SCHOOLS}

A number of specialized schools have been designed to serve certain education theories, such as Steiner and Montessori schools. However, these have not been discussed in detail in this thesis as they form a minority of schools, especially in New Zealand. The majority of New Zealand schools, which are state schools, depend mainly on single cell classrooms, with smaller numbers of open plan learning areas, so the focus of this research is on the single cell classroom. 


\subsubsection{DEVELOPMENT OF OTHER ENVIRONMENTAL ASPECTS OF SCHOOL DESIGN}

At the beginning of the nineteenth century, there was a stress and focus on having proper lighting and ventilation of classrooms and schools, although during that time there was less attention to the acoustics in learning spaces (Baker, 2012). Aesthetics and hygiene considerations, in the beginning of the nineteenth century, were also recognized as being important for school buildings in Britain (Seaborne \& Lowe, 1977). In 1851, a group of architects emphasized the connections between good aesthetic sensibilities and education. They claimed that the environment not only affected childhood, but also carried its implications "to the end of life" (Seaborne \& Lowe, 1977).

Following the compulsory education rule in 1880, doctors were worried about the large numbers of children housed in each school building. They emphasized the need for proper heating, ventilation, lighting, and acceptable sanitation in schools (Seaborne \& Lowe, 1977). In 1904, there were concerns about the average ventilation levels and the quality and number of sanitary fixings being not adequate in school buildings and the lack of any medical inspections in Europe. Doctors again requested proper light and airflow in school buildings (Chalet et al., 2008). It was also apparent there was some physical deterioration occurring in the learning environments and this led to emphasizing the importance of good seating for children (Seaborne \& Lowe, 1977). In the 
central hall plan, each classroom was in contact with the outside air on one side and the hall on the other side. On the other two sides, normally there were two other classrooms. With this arrangement, classrooms did not get proper cross ventilation. As stated in section 2.1.1.5, this was one of the reasons that open-air schools (veranda schools) were introduced (Seaborne, 1971).

After WWII, school plans had to consider daylight, ventilation, separation of departments, and isolation of noisy areas from quiet areas. However, there are conflicts when all these parameters are considered. For example, large windows ensure good daylight levels at the back of a classroom but large poorly oriented windows can easily lead to heat loss and cold classrooms in the winter and overheating on sunny days. Some acoustic separation can be achieved by building storerooms between classrooms (Seaborne \& Lowe, 1977) but controlling noise within a single cell classroom to allow both quiet (reading) and noisy (group working) activities to happen at the same time is much more difficult.

Unlike in the UK where the emphasis was on good natural ventilation, after WWII air-conditioning first appeared inside schools in the US. US architects also started to think about acoustics in school buildings, in addition to lighting, heating, and ventilation. After the energy crisis in 1973, in the US the need to reduce energy consumption in school buildings was given priority in school designs, and later in 
the 1990s, the green building concept emerged. Schools of each period were built to support these respective concepts (Baker, 2012).

In the 21st century, information technology has again changed the way schools are designed and built, as the technologies allow for new learning and teaching strategies. Technology has also improved the energy control systems in the schools, again leading to more energy efficient school buildings (Baker, 2012).

\subsubsection{Discussion of THE History of SCHOOLS}

The literature reviewed has shown how schools have changed, being based on many different models to meet the different needs of teaching and learning. Some models, such as the central hall plan, have appeared twice in the history of schools since general education became common, perhaps because such models work better than those that replaced them. Overall, changing the design of schools and classrooms has been an ongoing process from the emergence of the first one-room school until today. The models change frequently in the search of an ideal but as yet there is no model that has no weak points, at least for some people. Thus, changing the design of schools is a natural action to suit the different needs of learning and teaching for different generations and places. From following the designs of schools in history there is no indication that there could be one model that would suit all needs, users, countries, cultures, and teaching and learning strategies. Thus, 
perhaps each school should be designed considering the specific user needs for certain teaching and learning strategies that suit the culture of the place.

Another issue to discuss is the appearance of different activity zones in learning environments, emerging from the early layouts of one-room schools where the area was divided to hold more than one teaching session using different teachers. In open classrooms models, the area of the classrooms was big enough to contain different activities besides sitting at desks, even though there is no evidence that that the space was used for such activities. After these models, the traditional single cell classroom became the standard layout for some school models such as the central hall and corridor schools. Later the different activity zones reappeared in the open plan classrooms and studio based learning environments. These changes in the classroom layout might be related to the teaching styles used in the different time periods. The teaching styles were not the same in one room and open plan schools, but the layouts could still serve similar teaching styles. So, dividing the classrooms into zones for different activities is not a new idea, and has happened in different school and classroom models.

In terms of the controlling power in design and the design process, there have been some changes through history. In the early school models, specifically the factory model that was first found in Prussia, students and teachers had no say about the environments in which they learned and taught. 
Later, in 1872, the Department of Science and Art controlled the budget of schools, which may mean that the schools could not manage the budget according to their needs. There is also no evidence of considering user participation in the design of certain school models.

In terms of designing for environmental aspects, these were considered and did lead to changes in layouts. For example, after WWII, many schools were built catering for larger numbers of students. Because of the increasing number of users inside schools, more noise was created that affected the teaching and learning process. Thus, sound insulation was introduced in addition to seperating noisy areas from quiet areas.

\subsection{DESIGN ELEMENTS OF LEARNING ENVIRONMENTS}

There are many elements to be considered in the design of learning environments. Some are general architectural elements, while others could be considered specific to children's environments, such as small size furniture and furnishings.

\subsubsection{GENERAL ASPECTS OF DESIGNING LEARNING ENVIRONMENTS}

The elements of buildings or interior spaces can be divided into three types: first, elements that define the spaces, which are all the vertical and horizontal planes that create the space; second, elements that control the quality of space, which are the shape, scale, proportions, colours, textures, 
and lighting; and finally, elements that give the space a certain order, which are colonnades, arcades, walkways, and variation in floor levels. How these are manipulated will influence what type of classroom is created, from the single cell portable classroom box to the range of spaces, levels and textures found in some learning studios, and how both of these relate to other learning places, such as the outside. Educationists agree that the word "classroom" does not limit actual learning and education to within the space of the classroom. In fact, more learning can and should be completed outside the "traditional classroom environment" (Laiqa et al., 2011).

Children's spaces must also mesh with and contain a range of child related parameters:

a) Physical functioning, such as jumping, running, and skipping;

b) Physical development, which is the pattern of bodily growth and its interaction with surroundings;

c) Cognitive functioning, which is the response of children towards spaces and features;

d) Cognitive development, which examines the changes in children's memory, concepts, and language;

e) Social functioning, which is the response to and communication of children with peers or adults; and finally 
f) Social development, which explores changes in children's feelings (Said, 2007).

Authors from seven unspecified universities proposed three student rights related to learning environments in their "the classroom design manual". First, students should see everything related to subjects and learning topics presented visually. Second, students should hear everything presented audibly, without any noise or distortions. Finally, students should be comfortable in their learning environments. This comfort should include proper ventilation, room temperature, and furniture arrangement. Classrooms should be also designed with respect to their flexibility, adaptability, and ability to be effectively used for different activities (Laiqa et al., 2011).

In 2000, Yuen Ling Li carried out a study of preschool classroom organization in Hong Kong. The aim of the study was to help children achieve greater development through interaction with their physical and social environments. This study explored the organization inside kindergarten classrooms to discover something about the teaching routines. Observations of nine such classrooms, including the daily plan and timetable for each, set the framework of the exploration. The main focus was on the classroom organization, proportions of time spent in different activities, the teaching strategies, and classroom rules. The organization in the nine classrooms was similar. A typical 
classroom contained shelves, cabinets, and learning corners along its sides. There were chairs and desks at the centre of the classroom. The class sizes ranged from 9 to 32 children, which caused overcrowding in some classrooms. In crowded classrooms, teachers used available corridors and lobbies for teaching and learning, in addition to the main space inside their classrooms. The major sessions in the classroom were assembly, class teaching (mat time), group activities, break, music and physical movement, and "pack away time". Group activities utilized the majority of time, followed by class teaching, physical movements, music, break and toilet times, and finally assembly. One of the main conclusions of this study was that teachers tended to maximize the use of available space inside and outside the classroom, suggesting they were aware of the needs of children to experience different qualities of learning environments within the same classroom setting. In addition to the use of corridors and lobbies, in one of the classrooms children were divided into two groups during class teaching time. One group worked on tables completing worksheets while the other group was involved in craftwork or drawing (Li, 2006).

\subsubsection{FURNITURE AND THE FURNITURE LAYOUT OF}

\section{LEARNING ENVIRONMENTS:}

The two major functions of classroom furniture are supporting the child while attending to the teacher and while writing and drawing on a working surface. Although these two activities require different physical positions for 
the child, the assumption seems to be that the chairs and tables found in most primary school classrooms can provide support for both positions. Traditionally, classroom furniture has been used to keep children in place so as to control their behaviour and make monitoring their performance easy. Another function of classroom furniture is to allow children to move about in order to let them relax and prevent any localized muscle fatigue and pain from remaining in one position for a long time (Knight \& Noyes, 1999). The results of studying student postures while working at their desks indicate that chairs should be designed to allow for a backward tilt on the back rest, support student backs when they sit upright, and allow the seat surface to tilt forward to support them leaning forward to work at their desks. The existing school chairs that are supplied to provide these needs are generally shell chairs (the seat and back of the chair in one piece). However, according to the study, shell chairs can create upward pressure under thighs when students lean backward, as the backrest and seat are in one piece. The proposed design that emerged from this study was to have the seat separated from the backrest (Kane et al., 2006).

In 2007, a study carried out by Saarni et al. (2007) aimed to discover the average postures for students using chairs and desks and how these matched with child anthropometrics. The study focused on 101 students aged 12 and 14 from two comprehensive schools in Finland, so older than the primary 
school environments that are the focus of this thesis. The major outcomes of the study were differences between the desk height and elbow-floor height $(13 \mathrm{~cm})$, differences between chair height and popliteal height $(2 \mathrm{~cm})$. For $66 \%$ of the time students sat with their backs flexed $>20$ o degrees or rotated $>45 \mathrm{o}$ degrees, and for $70 \%$ of the time students sat with their neck flexed $>20$ o degrees or rotated $>450$ degrees. Chairs did not support children's necks or back bending. These outcomes revealed that the furniture used mismatched school student anthropometrics (Saarni et al., 2007).

Most studies of classroom furniture discuss the size and ergonomics of the furniture in comparison with the size and ergonomics of users. According to Legg (2007), ergonomics is defined as the discipline of understanding the relationship between humans and other elements of a system. In a school system the elements can include school equipment such as desk, chairs, books, and pens; work such as learning, teaching, and playing; work spaces such as desks, chairs, and work space arrangements; school environments such as classroom, corridor, and physical factors (heating, ventilation, lighting, etc.); and school organization such as subjects, curricula, learning/teaching methods, and physical activities. Legg claimed at the time of his writing that research had only been completed on a limited number of the elements of the school system. Research had mostly focused on "micro ergonomic" issues such as the mismatch 
between student body sizes and school furniture dimensions. Very little research focused on "macro ergonomic" issues such as the classroom environments and curriculum. Legg also claimed that there were no studies or applications using ergonomic knowledge and rules in classroom construction, school-building facilities, learning and teaching processes, and learning environments. Legg also suggested that ergonomic studies of school elements should be continued and move beyond research on the mismatch of furniture in schools. Studies should also create greater knowledge about school facilities and the education curriculum (Legg, 2007).

Apart from furniture design and ergonomics, there have a number of articles offering advice on how to furnish learning environments. In October 1968, the Utah Western State Small Schools Project and Utah State Board of Education published guidelines for designing, furnishing, and equipping small learning laboratories. In their definition learning laboratories were large open areas that could accommodate up to 150 students. They included all the equipment and materials that the students needed. These laboratories were designed according to a group of concepts such as "every student is a unique individual and should be valued as such", "all students learn from adults", "students learn best when they have freedom in and responsibility for their own learning", "it is more important that the child learn process than product", and "children must master the 
tool skills (reading, writing, arithmetic and process of learning)" (Merrell, 1968). The guidelines provided for furnishing and equipping these learning laboratories were based on experience in the use of this type of learning environment, reports from students who had used learning laboratories, reports from teachers who were involved in designing these environments, and observations by visitors. The guidelines dealt with designing the environment, how flexible it should be, and information about the furniture that should be used in it. In summary, the guidelines are that learning laboratories should be large and open areas, all human and material resources should be available for the students, there should be visual access to all areas, they should be treated acoustically, their furniture should be light and moveable, the laboratories should provide media (audio-visual materials) for individual and group use, they should provide private study facilities, and they should provide separate areas for music, experiments, and industrial education. They should also include storage for materials and records and this storage must be available to the students, and they should include special spaces for teachers (Merrell, 1968). Environments that have similar characteristics to those explained in these guidelines are now being applied in New Zealand (see section 4.2.4).

In 2000, Angie Dorrell, a director of curriculum for La Petite Academy Childhood program in the US, published the article "Tips for Furnishing Learning environments". The 
article covered what to consider when choosing suitable furniture for learning environments. The concerns were basically about safety, mobility, size, finishes, maintenance, and accessibility of the furniture. The types of furniture mentioned were tables, classroom shelves, chairs, dramatic play furniture, vinyl-covered furniture and sand and water tables. Sorrel also discussed the practicalities of how to select a furniture seller or trader in terms of purchasing policies (Dorrell, 2000). However, no typical classroom layouts were suggested.

In 2011, Kim Hassell published an article about flexible furniture in classrooms. Hassell suggested that classrooms should be large enough to contain different learning activities. Some classroom settings already offer a good environment for teacher-directed instruction, individual study, group work, and discussions and presentations. However, flexible classrooms and furniture should enable all these styles of learning to happen in one space. Hassell recommended using mobile furniture for mobile learning. Moveable chairs and tables would offer the learners an opportunity to change furniture arrangements to suit the learning style they were currently using, such as small or large group study. Hassell claimed that technology is essential in classrooms and furniture should be flexible to accommodate from 1 to 21 computers in one classroom. In addition to computers, different visual media should also be considered. The open plan concept experimented with in 
classrooms in the 1970s and 1980s had encouraged designers to place emphasis on flexibility in classrooms but Hassell suggested that openness was not necessarily associated with flexibility. Larger classrooms with movable walls and furniture could also offer flexibility (Hassell, 2011).

Rieber (1996) reviewed the approach of involving play in education and explored the relationships between play and designing interactive media environments. Rieber discussed micro-worlds, simulations and games as learning environments that encourage play. A micro-world is "a small, but complete, version of some domain of interest" ( $p$. 46). Micro-worlds are divided into natural and artificial. Natural micro-worlds are real micro-worlds such as a sandbox for children, supported with buckets and shovels. Artificial micro-worlds create some domains or systems for the user. An example would be the design of computer software such as LOGO that provides many domains related to geometry, physics or other science. Artificial microworlds can also be involved in natural micro-worlds.

To be useful in learning environments micro-worlds have two main characteristics. The first is that they should provide a simplified version of the domain. The second is that they must match the learner's abilities so that learners know immediately what to do with the micro-world. These characteristics are important for making micro-worlds "selfregulated learning". This means that learners take the responsibility for their education and learning. Simulations 
and games can work very well in supporting micro-worlds. Simulation, an attempt to imitate a real or imaginary system or environment, could be useful for both educational and scientific purposes. The reasons for not studying the real model of a system or environment could be cost, danger, inaccessibility, or time. Educational simulations are designed to give the learner the opportunity to observe the results of actions of a certain system or environment. The design of simulation as a micro-world should meet with the micro-world's characteristics, as well as being a simplified case and matching with the user's abilities. Learners might not be interested in participating in certain activities for a relatively long time. Researchers have found that characteristics for motivational learning environments include challenge, curiosity, fantasy, and control. Games represent these characteristics very closely, and as a medium can be designed for adults or children. Challenge in games could be increased or decreased to test the learners' abilities. Games also vary in complexity but feedback should be provided quickly for learners to evaluate their progress against the goal of the game (Rieber, 1996). Nowhere, however, is there discussion of the ideal classroom environment for supporting learning through micro-worlds. Including micro-worlds in learning environments, however, gives learning and teaching another dimension. Interactive elements in learning environments could encourage more engagement with learning, which could result in better 
learning outcomes. A full discussion of micro-worlds and interactive designs needs wide and detailed research, which is outside the scope of this research. This research focuses on the design process of typical classroom learning environments in New Zealand. Micro-worlds, are, however, a topic for further study.

\subsubsection{Discussion OF Design Elements Related to} LEARNING ENVIRONMENTS

Successful designs should not just rely on having good environmental aspects such as appropriate acoustics and lighting. Flexibility in the learning space accommodating different types of learning is also an important factor for learning environments. Although flexibility in learning environments has no one definition or set of rules, it has been discussed in different ways. Flexibility could mean having movable partitions inside learning environments, having movable furniture, having a space that could serve a range of activities, or even having spaces without any furniture. As flexibility in classrooms is never fully described, it could mean different things from culture to culture, from country to country, or from teaching style to teaching style.

The main aim of furniture in learning environments is to support students physically while they learn. Thus, furniture should not constrain the learning process but rather be capable of serving different user needs. It should work to provide the flexibility that learning environments need with the knowledge that flexibility could mean 63 
different things in different contexts. However, furniture is still required to be physically appropriate and suitable for students' body sizes, recognising that these can vary widely within one primary school classroom because children grow at different rates. The issue here is that there is the need to consider the role of furniture in providing flexibility inside the classroom and in supporting different teaching styles in addition to being ergonomically suitable.

\subsection{THE EFFECT OF LEARNING ENVIRONMENT DESIGN ON TEACHING STYLES AND LEARNING OUTCOMES}

From the 1950s and 1960s, a connection between architecture and teaching methods was made. In 1957, the Ministry of Education in the UK published a book "The story of postwar school building" that pointed out the need for different types of school that would respond to the variety of ages and abilities of children. It was felt schools should provide a wider range of subjects and enhance the teaching with practical activities. Classes would be broken into smaller working groups. Each group would follow different aspects of the subjects being taught, using different teaching materials.

The classroom physical environment is commonly given less thought than curriculum planning. Overall, it seems teachers learn to give less attention to space and physical settings inside a classroom in comparison to the focus on educational and social factors. However, it has been 
suggested that teachers could benefit from arranging the environments and the learning settings as an activity that would have an extensive impact on the activities and attitudes of both themselves and their students (Morrow, 1990). Perhaps people are not aware of the financial aspects of not designing a school environment that can support effective teaching. One architect estimated that teaching depends $99 \%$ on the teacher's ability and only $1 \%$ on the environment. On the other hand, a teacher has claimed that the built environment of the school can create and change the teaching methods for teachers and students (Seaborne, 1971).

Seaborne claims that teachers and students do not realise how important the surrounding building is for the teaching and learning process. Teachers and staff find it difficult to use their best teaching methods in unsuitable buildings (Seaborne, 1971). Researchers have also revealed a close relationship between learning environments and learning outcomes. In many cases, students are "passive recipients" of education in "adult-centred" environments. New education theories may encourage new teaching strategies that involve group work and collaborative learning; however, learning spaces may not provide the features required to implement these teaching styles (Bland, 2009).

The shape of a space can affect the architecture and interior design as well as the human and cultural behaviour. Users of the space can be affected directly by the shape, colour, 65 
texture, and furniture arrangement. For example, a chair can affect the general posture of the user through its shape, scale, and proportions (see section 1.1.2.2) and in the same way architects and designers can positively control user behaviour through their designs. Laiqa et al. (2011) conducted a research study to define the relationship between quality spaces and the academic achievement of students, with 80 second-year girls at higher secondary schools in Pakistan as the subjects of the study. Students were divided into two groups of 40 students. One of the groups, the experimental group, was schooled in a quality space while the other group, named the control group, was taught in an ordinary classroom.

The quality space was a purposefully designed classroom with all necessary facilities. Blinds were installed to control the intensity of incoming natural light, windows were double glazed to provide a noise-isolated space, light fixtures were arranged properly to illuminate the white board and writing areas without glare, and the walls and ceiling were painted with light colours to prevent glare from direct reflection. The other group was accommodated in an ordinary classroom in one of the government higher secondary girls' schools.

Both groups were pre-tested before the experiment. There was no significant difference between the results of the two groups at this point. In the experiment, the same teacher, the 
same teaching content, and the same schedule were used for both groups for 50 minutes a day, 6 days a week, over 3 months. After the period of the experiment, the two groups were post-tested. In the control group, there was no significant difference between their achievement in their pre-tests and post-tests. On the other hand, there was a "worthy" development in the academic achievement of the experimental group students in their post-tests. The main conclusion of the study is that well designed spaces greatly affect student learning and achievements in a positive manner (Laiqa et al., 2011).

The furniture layout in classrooms also affects children's behaviour. The design of the furniture has implications for how it is used. For example, traditional rows of chairs in classrooms, in comparison to modern styles of movable/grouped tables, make students spend more time on-task (Knight \& Noyes, 1999).

Some schools have been built to support and encourage certain teaching methods or aims, but teachers often frustrate these. For example, in one school, classrooms were built with no focal point (such as black or white board) to encourage teachers to work as supervisors instead of instructors or lecturers. Teachers ended up covering one of the classroom walls with brown sheets of paper and using this as the focal or control point. Another example comes from two classrooms that were designed with wide openings instead of doors to encourage sharing of resources 
between teachers and students of both classrooms. In this instance furniture was moved to create a partition and give each classroom some privacy (Seaborne, 1971).

Featherston defines creative learning environments as very busy spaces full of people, movements, and things. However, there is a need to offer richness and stimulation at the same time as offering a calm and rational environment. The space should be visually and functionally pleasant, with a controlled palette of finishes and mainly warm natural colours. Creative learning spaces should enable children to choose the activity they want, in the place they prefer, and with people they desire. This will make children relaxed and ready to learn. Three layers (the building shell, internal settings, and loose items) can create a learning space. However, all the three layers should work together to form a functional and visual flow to make the space a creative learning environment (Featherston, 2010).

Some teachers may adopt new teaching methods and educational aims over the years, whereas other teachers prefer their original styles of teaching. Both categories may teach in the same design of school. How teaching should be done has long been a subject of discussion. In 1899, the American John Dewey introduced "child-centred" education in his book The School and Society. He focused on aspects such as "learning by doing" and working on projects. In 1912, "the Montessori method" for young 
children developed by Dr. Maria Montessori was published in English. In 1922, Miss Helen Pankhurst's Dalton Plan was published. These methods and ideas have led many teachers to change their attitude towards students but few classrooms would have been redesigned, or even rearranged, to support teachers trying out these new initiatives (Seaborne, 1971).

For example, Montessori education suggests dividing the classes so as to have a group of multiple ages in each class. It also suggests using certain educational materials for learning. Montessori education involves student-selected activities, collaboration in learning, no exams and grades, and learning and instructing in both individual and small group settings (Lillard \& Else-Quest, 2006). There are special classroom requirements for teaching with Montessori methods. For primary school levels, the classroom needs to represent a small house containing a suitably sized kitchen, classroom library, science area/lab, greenhouse, and art studio. In addition to these zones there are requirements for the floor finishes, lighting, windows, and outdoor settings. For example, the outdoors should face a natural setting of gardens, forest, or fields (Seldin, 2001).

Another theory that requires special classrooms is the multiple intelligences theory (see Chapter 1). The multiple intelligences theory is defined as the ability to solve a problem or create a product that is valued in one or more societal or cultural settings (Baum et al., 2005). Learning 
environments that utilise multiple intelligences theory may work better in certain settings. Classrooms may contain different activity centres that support the different intelligences in the theory. For example, settings such as a language lab, a writing centre, and a reading corner could serve linguistic intelligence (Armstrong, 2009).

\subsubsection{DisCUSSION OF THE EFFECTS OF LEARNING ENVIRONMENT DESIGN ON TEACHING AND LEARNING}

The connection between teaching styles and learning environments suggests the need for better knowledge about the connection between the design of learning environments and student learning outcomes. Teachers with certain teaching styles would benefit from having special learning environments that support these, thus making the learning process easier and more engaging for students, which should in turn lead to good learning outcome. A number of studies seek to explain these connections, while other studies provide suggestions for designing learning environments according to a certain teaching style or educational theory. Thus, considering teachers and students as partners in the design of learning environments should reinforce these connections. However, despite these many theories there is little evidence that primary schools in New Zealand have changed greatly in how they are designed. Many children in New Zealand are still taught in traditional single cell classrooms (see section 4.2.3.1). 


\subsection{CONCLUSIONS}

This chapter briefly discussed the history of school buildings and classrooms and the design of learning environments.

Classroom models have changed many times over the years in order to serve the ongoing needs of students. However, some old models are still used in school buildings, such as the single cell classroom, in addition to the relatively newer models, such as learning studios and advisory models. Environmental treatments have also developed and improved over the years. The application of proper lighting, heating, ventilation and acoustics has progressed as it became apparent these were needed in schools. The different layouts and environmental aspects were developed according to certain needs that appeared throughout the history of school building. However, it seems there is no ideal layout for learning environments as different layouts have appeared, disappeared and then reappeared while others never reappear again. Design of learning environments should thus be according to the needs of learning and teaching of certain users at a certain period of time.

Those designing learning environments have different elements to consider, such as elements like colour and texture that give the space value. Other elements are related to children, such as providing suitable spaces for children's activities. Furniture and furnishing also affect the design of learning environments. Furniture should be suited to the 
different body sizes of children. Furnishing learning environments should incorporate many aspects, such as arranging the furniture to serve direct instructions, individual study, group work, and discussions and presentations. Finally, this chapter provided information on the importance of having good learning environments for better learning outcomes. This includes designing the internal layouts of classrooms to serve different teaching styles.

The following chapter discusses how good designs for learning environments, with all the elements described above, benefit from user participation. 


\section{CHAPTER 3: THE CLASSROOM DESIGN PROCESS}

The previous chapter discussed the evolution of schools and classroom buildings, as well as some key elements to consider in designing quality learning environments. One of these elements is the involvement of users in the design process. This chapter gives a brief overview of participatory design in learning environments, creating a template for comparison with the current design process of New Zealand learning environments.

This chapter is divided into five main sections. The first is a description and discussion of participatory design in general. It focuses on the reasons for using participatory design and explores some methods for undertaking this type of design process. The second section provides information about the involvement of teachers in designing learning environments. It provides examples of teachers' work with the aim of creating suitable learning environments for them and their students. The third section discusses children and participatory design. It contains two subsections, the first of which discusses the involvement of children in decision making. The second subsection explores the involvement of children in making learning environments and children's spaces. The fourth section in this chapter provides two examples of participatory design in learning environments. The first is about designing schools in general and the 
second about the design of a learning studio. The final section discusses the importance of post occupancy evaluation in the design process.

\subsection{PARTICIPATORY DESIGN}

Design should ideally be a social process that involves communication, negotiation, and agreement. Studies stress that the design process itself should be as important as the finished product. As products, including buildings, are designed in order to be used by people, designing should involve creating the product and setting rules for how it could be used. In the design process, the designer should understand the language of certain products (materiality, tectonics), the users should understand how to use the products designed by the designers, or/and the users should give clear descriptions of what they need (Brandt, 2006).

Participatory design has become more prevalent over the last 20 to 30 years. It was originally used primarily in information and communication technology. Now, it includes fields such as space design, product development, industrial design, architecture, service and transformation design (Sanders et al., 2010).

User involvement in designing and decision making, which is known as participatory design, has been said to have a positive influence on any design process (Luck, 2003). Participatory design changes the design process to be more of a social process, where the steps in making a design involve people other than the designers. Users who are 
involved in participatory designs as part of society play an active part in decision-making in the design process. Ideally the roles of designers and users should intermingle so they become equals in the design process. The variety of views voiced by participants during the design process can affect the final result of a project (Luck, 2003).

Participatory design is a good choice for designers who seek to improve the quality of their work. To achieve any design goals successfully, sharing information and responsibilities with users should be considered a significant aspect of the design process (Demirbilek \& Demirkan, 2004). The two main reasons participatory design is a good design option are that this approach focuses on the verbal exchange of design ideas during the early concept phases of design, which can enrich these, and the final outcome of participatory designs should reflect user needs, especially people with special needs such as seniors or children (Luck, 2003). Successful participatory design could improve the value of decisions, reduce costs and delays, anticipate public concerns and attitudes, and develop public knowledge and creativity (Sanoff, 2011).

There are many techniques and approaches used in completing participatory designs in a variety of fields and at different stages in the design process (Luck, 2003). As each project in any field needs different methods and tools for completion, the involvement of users will vary. Participatory design involves different people from different 
backgrounds and thus different methods and techniques have been used from its inception (Sanders et al., 2010).

There are a number of variables that should be considered carefully in any participatory design. The first is the group size and composition. Participatory design can also be completed with individuals or with groups, although a group should contain at least two people. The second variable is the method of meeting with participants. Traditionally, participatory design sessions are conducted face to face, but this is expensive and time-consuming. The growth of technology and the introduction of online communication media, such as Skype, have made it easier for more people to be involved in the design process. Online approaches also include blogging and video logs. The third variable is the venue. Participatory design sessions can be held anywhere. Usually they are held in the environment of the users, or in a design studio or conference room. Some participants might need to travel to the venue, which could adversely affect the number of participants. In online meetings there is no need to worry about the venue, which could favour the promotion of online over face-to-face meetings. The fourth variable is the relationships formed between stakeholders or designers and the participants. Participatory design can also be a one-time event or a continual relationship, with the latter preferred for better results. Preparations for the meetings depend on the relationships between stakeholders or designers and the 
participants and include whether those involved need to be paid, the time needed, and the methods and tools suitable for controlling the group. The last variable is the tools and methods used in the participation sessions. The sessions could be completed in workshops or by using a research plan that includes a combination of the three types of appropriate activities: making, telling, and endorsing. These three activities could include many actions. For example, making activities could be the construction of models or future design products. Telling activities could be in the form of a photo diary of how the product might be used (Sanders et al., 2010). Methods to complete participatory design also could include community surveys, review boards, advisory boards, taskforces, neighbourhood and community meetings, public hearings, public-information programs, and interactive cable TV (Sanoff, 2011). Table 3-1 summarise the different variables in participatory designs.

TABLE 3-1: THE DIFFERENT VARIABLES IN PARTICIPATORY DESIGNS (SANOFF, 2011).

\begin{tabular}{|ll|}
\hline Variables & \\
\hline Group size & Individuals or groups \\
\hline Composition & Age and occupation \\
\hline Ways of meeting with & Face to face \\
participants & Online communication media \\
\hline The venue & The environment of the users \\
& $\begin{array}{l}\text { Design studio } \\
\text { Conference room }\end{array}$ \\
\hline
\end{tabular}




\begin{tabular}{|ll|}
\hline Variables & $\begin{array}{l}\text { Online communication media (for online } \\
\text { communications) } \\
\text { Other }\end{array}$ \\
\hline $\begin{array}{l}\text { Relationships between } \\
\text { designers and the }\end{array}$ & A one-time event or a continuing relationship \\
\hline participants & Wools and methods \\
& $\begin{array}{l}\text { advisory boards, taskforces, neighbourhood and } \\
\text { community meetings, public hearings, public- } \\
\text { information programs, and interactive cable TV }\end{array}$ \\
\hline
\end{tabular}

An example of using participatory design was in the design of a multi-functional building at the Whiteknights Campus of the University of Reading in UK in 2001. The project was conducted by Rachael Luck, an architect and lecturer at University of Reading, with a group of architects and researchers (Luck, 2003). The building was designed to be accessible for people with special needs. The process to develop the design brief included semi-structured interviews with the future building users about their needs, desires, and expectations for the new building. People who were interviewed included those with a range of disabilities and people with no known disability. The process also included a probability study and analysis of the participants' views. A direction-finding committee (there is no information about the members of this committee) discussed which ideas would be taken forward in the project. All the 
stages were connected and supported the results of each. As a result, the brief for the building reflected the participants' needs rather than reflecting general guidelines. The disadvantage of using the participatory design in this project was that sometimes suggestions made by participants limited the design solution, especially since users may have no experience about how to design and what design terms mean. In this project, the language used in discussing the appearance of the building was limited, so there was very little discussion and the resulting solutions were very limited (Luck, 2003). Images or illustrations for this project were not found.

Another example of using participatory design was a project for designing products to go into a building for elderly people such as door handles, door screens and multipurpose shelves (Figures 3-1 - 3.3). The participatory design model was chosen for this project in order that safe and suitable independent living spaces for the elderly would be created. The design process included brainstorming sessions, scenario building, unstructured interviews, sketching, and videotaping and during these activities the elderly users' needs were compared with the design requirements. The design process was in five stages. In the first stage, the designers and the elderly participants gathered in design sessions that involved scenario building, brainstorming, idea writing and sketching, unstructured interviews and asking pre-set questions. Participants were 
expected to produce ideas and identify their needs. All the ideas and needs were discussed and analysed by the designers to create conceptual design solutions (Figures 3-1 -3.3). In the second stage, these conceptual design solutions were presented to the elderly participants. The elderly participants were asked to discuss and criticize the ideas and concepts in the solutions presented. Following this the designers made improvements and modifications to the design solutions and produced more technical and detailed drawings of the products. In the third stage, the designers created prototypes of the products to show the users in addition to the detailed technical drawings. The fourth stage included trials of the prototypes of the products by the elderly participants. The designers observed the users engaging with the prototype products and comments and new ideas were recorded with a view to upgrading them. The final stage was the production phase, in which the final designs were manufactured and provided to consumers. The participatory design in this project proved that involving the elderly participants in the design process enhanced the design solutions. The experiences of the elderly users were reflected in the final products. Another advantage of using participatory design in this project was that participants gained more knowledge about and awareness of the results of the decisions that were made (Demirbilek \& Demirkan, 2004). 


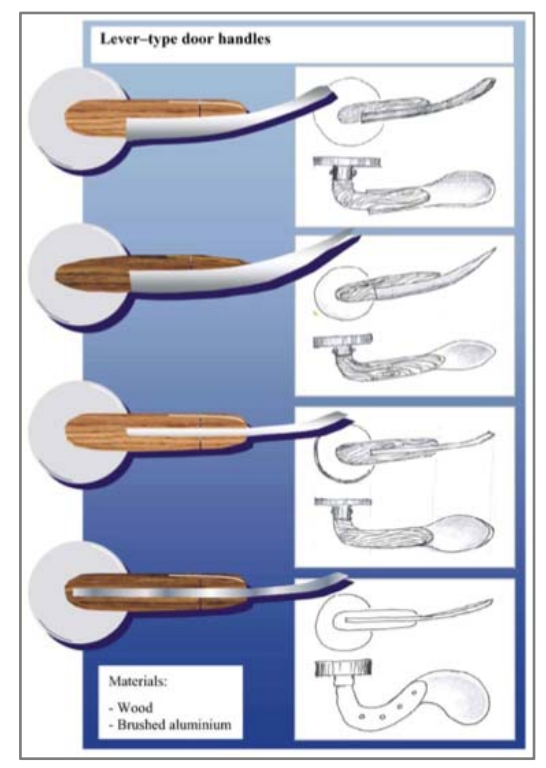

FIGURE 3-1: SKETCHES FOR THE DOORHANDLE DESIGNED WITH PARTICIPATION OF THE ELDERLy (DEMIRBILEK \& DEMiRKAN, 2004). 


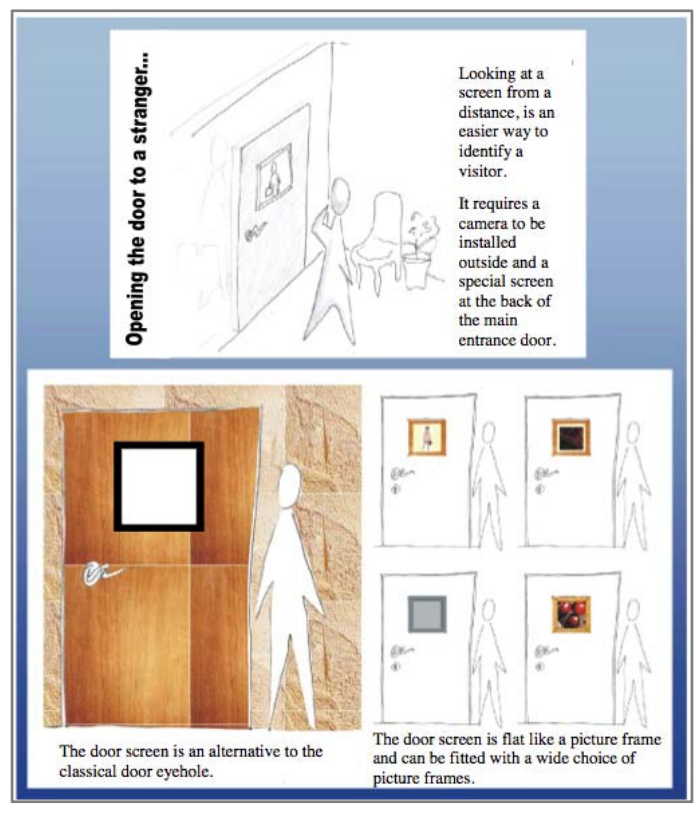

FIGURE 3-2: SKETCHES FOR THE DOOR SCREEN DESIGNED WITH PARTICIPATION OF THE ELDERLY (DEMIRBILEK \&

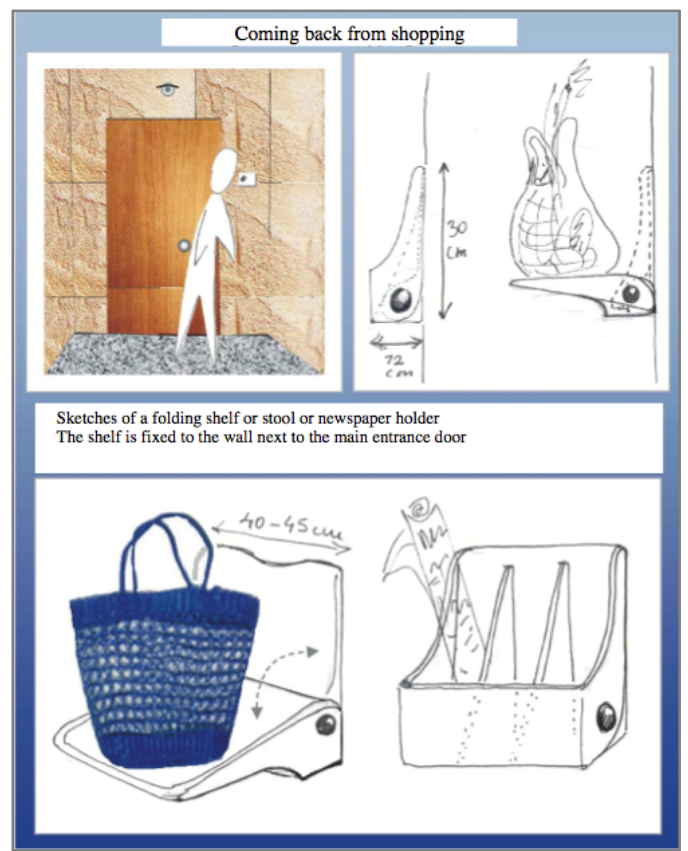

FIGURE 3-3: SKETCHES FOR MULTI-PURPOSE SHELVES DESIGNED WITH PARTICIPATION OF THE ELDERLY (DEMIRBILEK \& DEMIRKAN, 2004). 


\subsubsection{Discussion}

Participation of users in the design process seems, from the case studies, to be very important for producing designs that meet user needs. It also seems that participatory design can be applied to any design process and with a range of methods. Designers need to consider the methods that best suit the type of design and users and this may be a problem as few designers have, as yet, had much engagement with participatory design and will not be aware of what these methods might be. Although there are negative aspects to participatory design, such as the time it takes and having to find locations for participatory activities and the cost this might involve, these difficulties seem minor in comparison with the positive outcomes of participatory design, so how might participatory design be used in the design of learning environments?

\subsection{TEACHER INVOLVEMENT IN DESIGNING LEARNING ENVIRONMENTS}

There are very few articles and studies on teacher involvement in the design of classrooms and schools, apparently under the assumption that this is a less important area for research compared to the involvement of young students.

However, some teachers and educators have participated in designing their learning environments, ranging from a kindergarten to a high school. For example, David Loader, 
an education consultant and associate professor in the Faculty of Education at the University of Melbourne, talks about his experience of visiting a classroom without furniture. There was just a carpet. Students gathered in different groups completing different activities such as lying down to read books, working together on creating a model for something, or sitting with laptops searching for or reading certain information. Loader explains that the classroom was not designed to be furniture-free. In fact, the classroom was new and teachers and students were waiting for the new furniture (chairs, tables and whiteboards). However, neither students nor the teacher were bothered by the absence of furniture. Loader argues that the furniture might be limiting the activities inside the classroom. He discusses traditional classrooms as being equipped with tables for students to work on and white or blackboards for giving instructions, thus suggesting a particular style of teaching and learning. Loader considers classrooms still need a number of chairs and tables, and some comfortable settings for activities such as individual study, group study and comfortable reading, so the furniture should be designed to serve such activities. However, he (Loader, 2010) poses the question, "Why not experiment with a learning space with minimum furniture?"

Helen West (2007) was a primary curriculum adviser at the Inner Western Region of The Catholic Education Office in Sydney, where a team of kindergarten teachers started a 
programme for establishing kindergartens in inner city schools in Sydney. One of the important factors they dealt with was designing the learning spaces in these classrooms. Children in these kindergartens were from different cultural and linguistic backgrounds. Teachers were interested in adapting play-based learning and using it as the basis for the design of the learning environments. The educators' team and the teachers involved wanted the spaces to be flexible, accessible to all, and reflect student needs. For example, partition walls were designed to create more flexibility by making these moveable to create larger or smaller spaces, as needed. The decision was made to remove a lot of the conventional furniture to create larger furniture-free spaces inside classrooms. Bookshelves were used as partitions or dividers between different activity corners. The aim was to design settings to support interaction between peers, quiet study, and reading and listening activities.

Teachers are often concerned about the design of the learning environment they work in, and some teachers try to collaborate with their students to deliver a space that maximises their learning. For example, in order to change the physical arrangement of their classrooms and create ideal learning spaces, some American high school teachers have suggested using trapezoidal tables to have more free space in their classrooms (Figure 3-4). Other teachers have recommended placing desks in a horseshoe shape for better communication inside the classroom (Figure 3-5). Anita 
Arnold, a high school teacher in Texas, USA, said that she placed her desk facing the wall, thus "eliminating a barrier" between her and her students. She also put her textbooks with her students' books to let them feel that she trusts them to use her stuff. She arranged the classroom to contain a publishing area, computers, plants, and colourful posters. High school teacher Richard Williams, from Georgia, USA, asked his students to choose the classroom posters from a collection provided by the school. Williams also asked students to hang up the posters in the places they preferred. He says that this was to make the classroom belong to those students. Steven Ronson, a high school teacher in Nevada, USA, says that his classroom had gradually changed from having five rows of desks to a "three-sided seating arrangement" with free space in the middle (Figure 3-6) (Arlond et al., 1993). He says that this arrangement helped the class in performing drama. The drama classes became easier as students experienced performing written plays in a staged setting. Kathy Proctor, a high school teacher in North Carolina USA, designed the layout of student desks for learning activities that encourage cooperative learning, peer editing, and classroom competitions. She arranged desks in seven groups of four. Some desks faced the front of the classroom, others were slanted, and some faced the opposite side. However, all students had clear views of each other, the teacher, and the board (Arlond et al., 1993). 

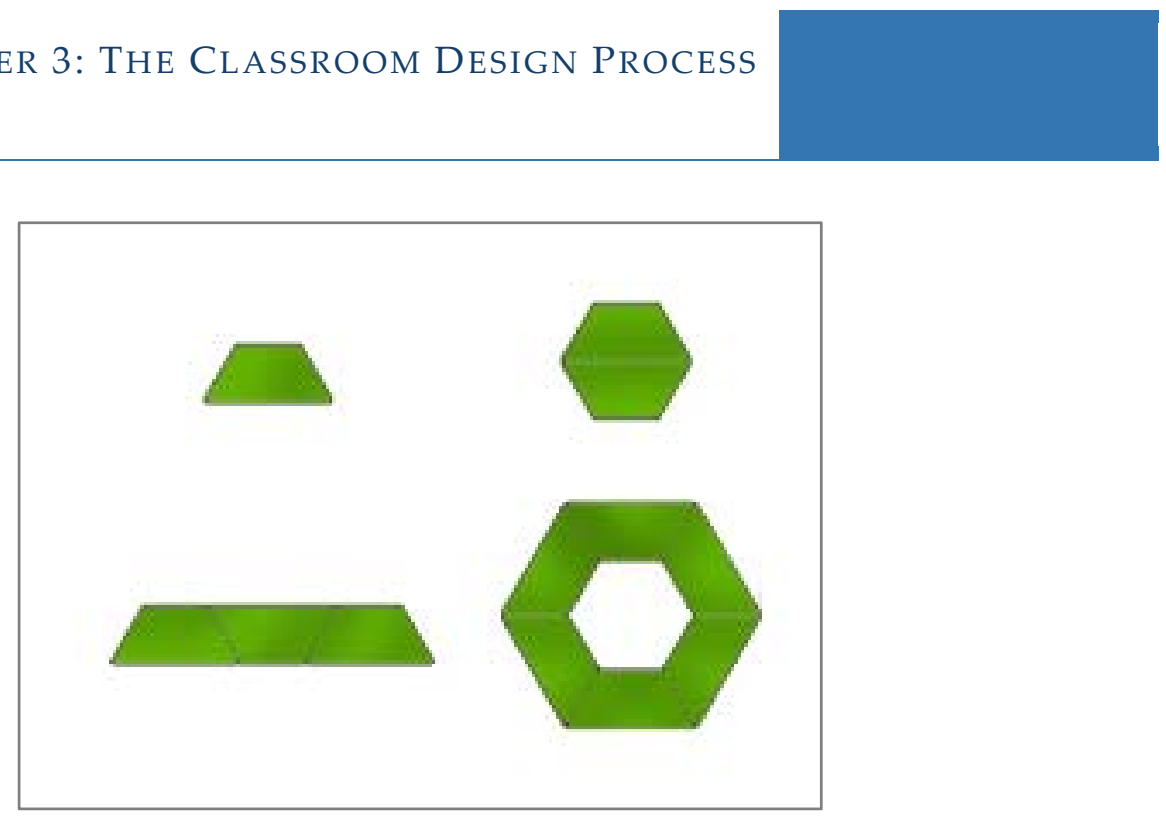

FiguRE 3-2: DifFERENT TRAPEZOIDAL TABLE LAYOUTS TO SAVE SPACE.

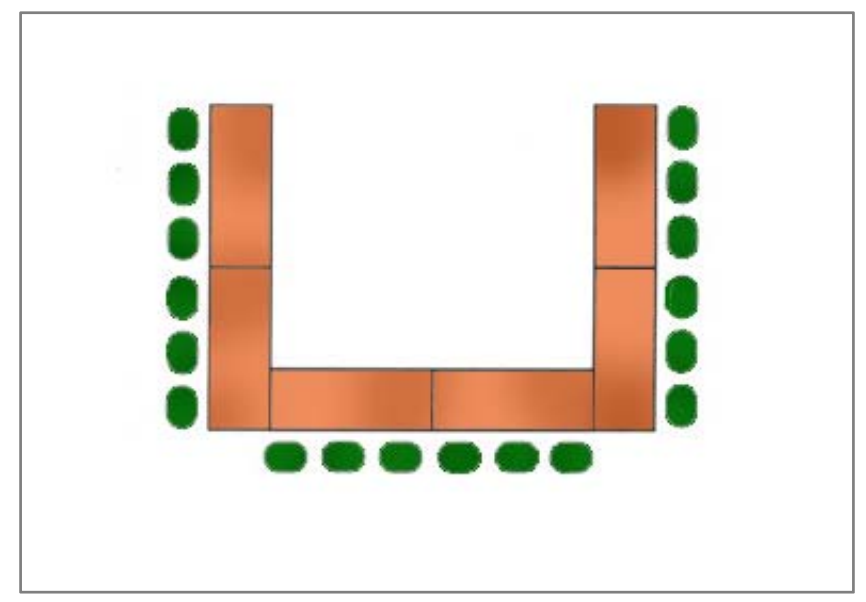

FiguRE 3-3: HORSESHOE-SHAPED TABLE ARRANGEMENT. 


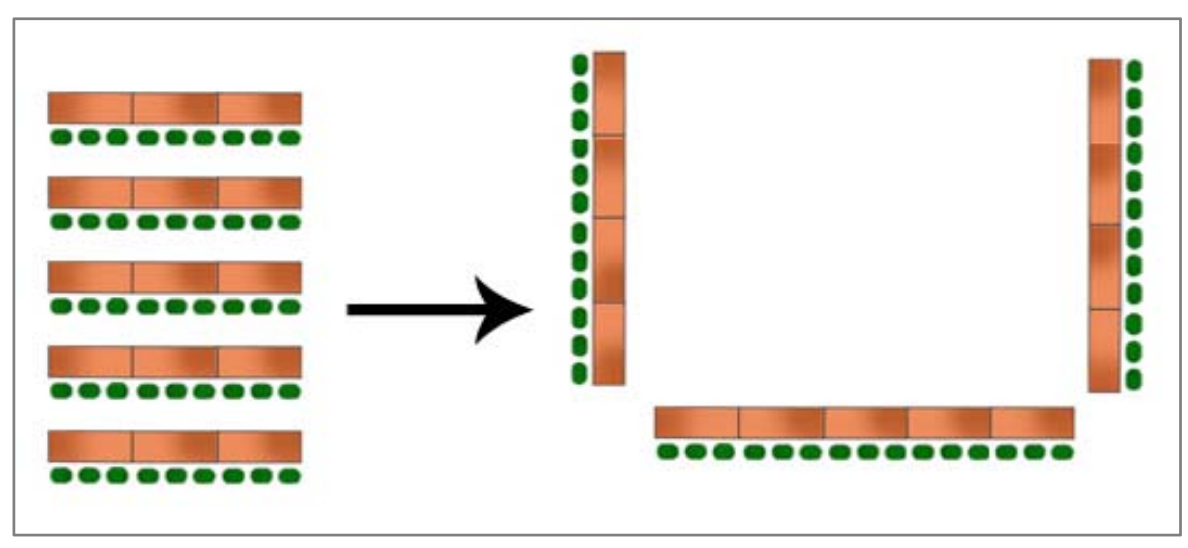

FIGURE 3-4: CHANGING THE LAYOUT FROM FIVE ROWS OF DESKS TO THREE-SIDED SEATING

In addition to studies and articles about the involvement of teachers in designing learning environments, there are two American websites that encourage teachers to involve students and give them tips on redesigning their learning environments. The "Classroom Architect", (http://classroom.4teachers.org/index.html) provides tools to help teachers with this. The first is a set of tools to draw the floor plan of the classroom and arrange the furniture in different layouts to achieve the best use of space (Figure 3$7)$. The tools provided can only draw rectangular or square floor plans, which can be a disadvantage for classrooms of different shapes, such as an L shape. Teachers can use the furniture from the template provided on the website or draw their own furniture. However, the furniture shapes in the template are also limited to being square, rectangular or circular. This section also gives some instruction on using the tools. 
The second section provides information on how the learning environments affect the learning outcome. It explains that there is no ultimate design for classrooms, as each classroom needs to be designed according to its students' needs and nature. A group of elements for successful classroom designs are mentioned, such as having neutral colours for walls (gray, off-white, beige), preventing overcrowded corners as these can result in behaviour issues, and creating different zones that serve different learning styles, such as individual and group work. The third section provides examples of classroom floor plans to instruct teachers about layout possibilities, however this link was not working at the time of completing this thesis ("Classroom architect", 2008). 


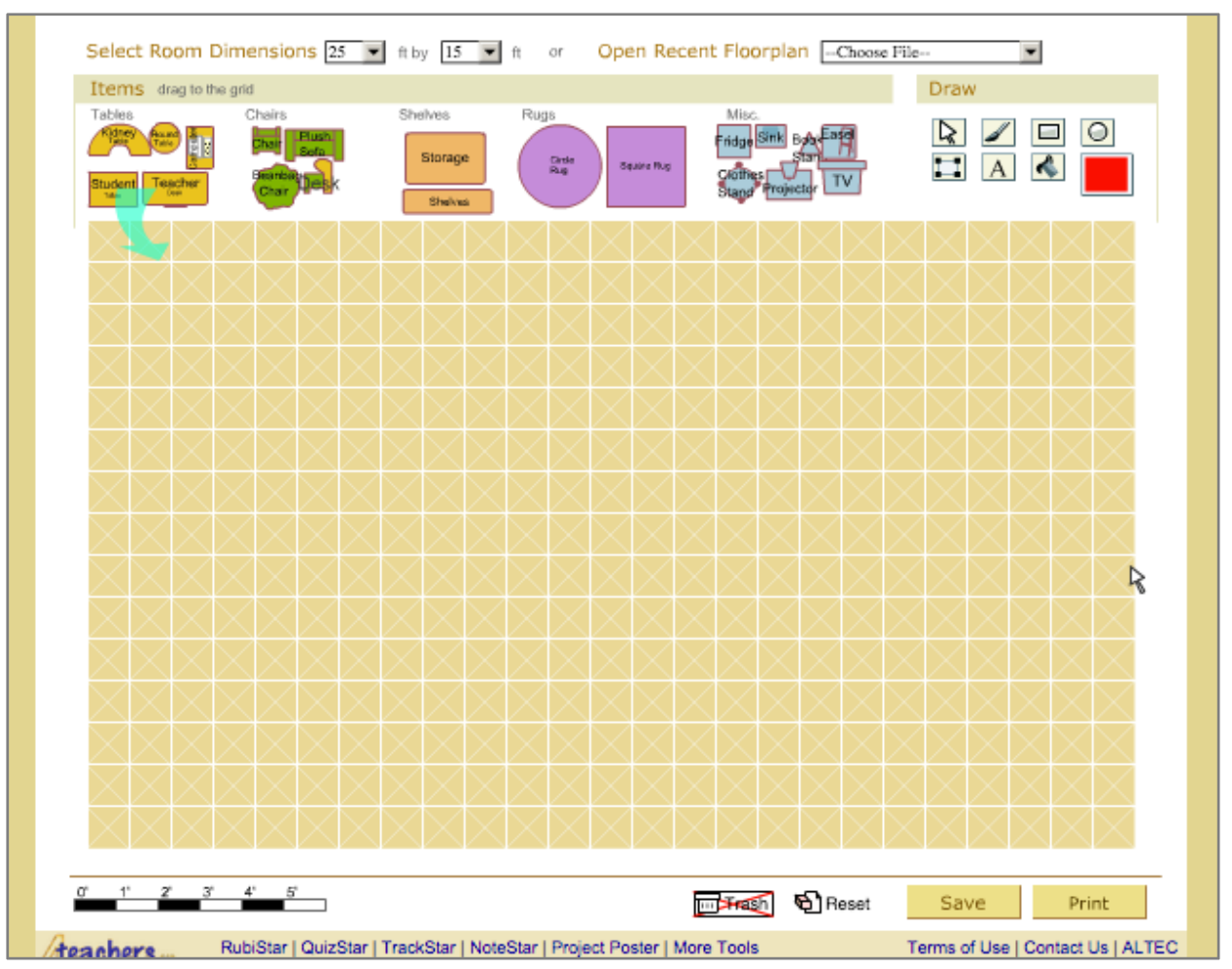

Figure 3-5: "Classroom ARChitect" tools to DRAW AND FURNISH CLASSROOM FLOOR PLANS. A SCREEN SHOT FROM “Classroom ARCHITECT" (2008).

The other website is linked to the "Edutopia" website, which is a website that provides tips about what works for education, written by David Bill, a designer and educator. One of the topics gives eight tips and tricks for teachers when redesigning or reorganising their classrooms. The first tip is to involve the students, as the main users of the classroom environment. Bill suggests this could take different forms, such as creating visual inspiration, like looking for photos of classrooms from magazines or the Internet. Another way of involving students is to have the existing classroom floor plan printed at large scale and then allow students to comment on how they feel about 
everything in the classroom. The second tip is to use research and brainstorming methods in the redesign process. These could involve subjects such as how to create collaborative space in the classroom. The third tip is organising volunteers to help the teacher in the design process. The fourth tip is to remove all unnecessary items from the classroom, and the fifth is to define any new materials and settings that are required for the classroom before starting the redesign. The sixth tip is to recycle and re-use materials available. For example, plastic containers from the grocery store could be used as storage units. The seventh tip is organising the classroom tools according to frequency of use. Colours or labels on the storage units could be used to define the use and frequency of use of each set of tools. For the last tip, the author provided a list of links for additional resources teachers could learn from and use in their redesign process. These resources include books, photos and information about some educational projects, some guidelines for designing learning environments, and some research about designing learning environments (Bill, 2014).

\subsubsection{Discussion}

Teachers are one of the main users of learning environments and so their involvement in the classroom design process is very important in order for the designs meet their needs and support their preferred teaching strategies. Teachers can be involved in designing learning environments in the same way, as any adult client is involved in any type of design. 
They can meet with designers and architects without the need to conduct research and design special sessions for them. Thus designers could use general participatory methods to deal with teachers. For these reasons, there are no specialized studies on methods for teachers to participate in the design of learning environments. Instead the studies available are about observing and investigating the role of teachers in changing the internal layout of learning environments, as with the discussion of teachers in the US changing their classroom layouts to suit their own and their students' needs (Arlond et al., 1993). The involvement of students in this process is potentially more complicated. Students, especially those in primary schools, need special care when involving them in any adult run design process.

\subsection{PARTICIPATION OF CHILDREN:}

As children are the main users of learning environments apart from teachers, this section presents results of a review of literature about participation of children in any design process or decision making in general, and in learning environments specifically.

\subsubsection{PARTICIPATION OF CHILDREN IN DESIGN IN GENERAL}

Involving children in decision-making is more than just asking them for ideas and views. It is about listening to them, taking them seriously and converting their ideas and suggestions into reality. Involving children should reflect how they could have an impact on things that affect them. This can help deliver and achieve services that cover 93 
children's needs, in addition to giving children more confidence. There is a big difference between participation and consultation. Consulting children means asking students about their views, while participation means giving children the opportunity to be part of the decision making (Ministry of Social Development, 2003).

International researchers have noted that giving adults the power of making decisions in any field could affect the adequacy of involving young people in the design process (Mannion, 2007). Researchers claim that children have good potential for participating in design processes, and that this should be a recommendation (Nesset \& Large, 2004). Child and developmental psychologists claim that children can face difficulties in completing the tasks and activities set them and argue that these difficulties are related to the children's environments, as these environments offer them insufficient room for learning and developing. Psychologists point out that enabling the participation of children in designing the environments they use could prevent some of these problems. Studies also show the social participation of children affects their mental health. Involving children as active components of their environments in addition to involving them in managing and arranging events in their lives could contribute towards giving children confidence and mastery over their lives and health. Long-term use of dependent environments may lead children to develop problems in defining their abilities to complete responsible 
actions. When children are involved in decision-making, they learn, gain experience and end up with confidence and self-respect (De Winter et al., 1999).

The participation of children in making decisions about the spaces they use needs re-thinking. The discussions cannot be just among children. There needs to be a set of different relationships between children and the adults involved, and between professionals and their child-clients in particular. Mannion (2007) provides an example where student's opinions were sought in a project that involved the school grounds. Children were dealt with as students, as children who need protecting, and as children who could make a difference. The main finding was that the different ways of identifying children were evident in the outcomes when children were involved in developing different types of school grounds with adults (Mannion, 2007).

Children may bring ideas and thoughts that adults might not conceive because of their practical experience of living in environments but this also means that some of the ideas of children could be impossible to implement. Thus, it is recommended to limit the expectations of children before they start to generate ideas, by providing a brief description of the project and the design process (Nesset \& Large, 2004). However, such a presentation will set boundaries as conceived by the adults involved, thus again the participation of children is not the same as that of the professionals and adults. Children's participation is also 
usually affected by the attitudes of the adults involved, although adults are also affected by memories of their own childhood experiences (Mannion, 2007).

There are studies aiming to define ways to involve children in the design process and decision-making. Nesset and Large (2004) describe four levels of action that children can undertake in any design process. The first is being given a random design so that those involved can observe and study the impact of the design on the children. The second action is testing prototypes of the specific design, and again observing the children's reactions to these. The third action is children participating in the design process at different stages, and collecting what the children think of this through observations or interviews with them. The last action is allowing the children to become a design partner, which means that children and adults are equal partners in the design process (Nesset \& Large, 2004).

According to Mannion (2007), listening to the 'voice' of children when it comes to participation, can occur in three ways. The first is listening to children who have something to tell the adults, and that thing may change the adults' decisions on behalf of the children. This method is considered strong when children are using the service that the adults are researching. Children's participation in this manner provides important information for the adults and gives them an opportunity to provide for children's services such as health, welfare and education. However, in this 
method, adults can easily change what children have said in accordance with their own ideas. The second way for children to participate is dealing with children as complete individuals or citizens with all the rights and responsibilities that the adults have. This is usually used in political services and services involving children's rights. There are some arguments that this method brings tension to the research, as children may make undeveloped decisions. The third approach is related to the second approach but here children's participation in civic activities is intended to encourage a sense of duty and commitment to society. The second approach realizes children as citizens and the third approach treats them as a minority group struggling to be heard and be socially included while still children (Mannion, 2007).

Cities around the world, from Berkeley, California to Milan, Italy, have involved children in the design process of planning aspects of the city. Some cities have applied children's ideas into the final plans and designs. The success of many designs in city planning, such as playgrounds, parks, and streets, depend on the involvement of children and other users in the design process (Francis \& Lorenzo, 2002). In designing neighbourhoods, children are mostly treated as objects in the neighbourhood, which means that the elements related to children, are designed without involving them. For example, playgrounds are mostly designed for children but not with children. In these cases, 
children feel that their opinions are not worth listening to (De Winter et al., 1999).

Children's participation in designing cities can be divided into seven time frames, or realms. The first is the romantic realm, also known as "children as planners". In this realm, children are thought to be the planners in the planning of their own futures and environments. There are no professional planners or designers engaged in this realm. In addition to designers and researchers, other parties such as schools, architects, and communities have used this realm of participation in their research or in projects in order to create child-defined cities. This realm developed methods to involve children in designs such as "environmental autobiography where adults were asked to remember and draw their favorite childhood places" (Francis \& Lorenzo, 2002). It also created an idea of what cities would be like if designed entirely by children. This realm is still used in some research concerned with generating ideas from children (Francis \& Lorenzo, 2002).

The second realm is the advocacy realm, or "designers for children". In this realm, designers design according to children's needs. It again developed from designs and projects in the 1960s when citizens did not have any input in projects that affected their lives. This realm is intended to be used by citizens and public planning designers and includes theories of working with children. However, it has drawbacks, such as creating places far removed from 
children's personalities. This realm has since faded and been replaced with other realms.

The third realm is the needs realm, or "social science for children". This realm is a research-based method that tackles children's special needs. It is used mainly by academics, but some design and policy makers also use it. The needs realm has contributed in creating principles for good environments for children. Unfortunately, this realm has not always focused on involving children in reaching these principles. It is still used for designing children's spaces.

The fourth realm is the learning realm, or "children as learners". In this realm, the focus is on teaching students about architecture and planning through participation. Teachers and environmental educators usually use this realm. This realm has helped in developing participation methods and also in increasing the planting of vegetation in outdoor spaces used by children as it focuses on environmental learning. The limitations of this realm are that children are often not directly involved in the research and that decision makers do not always apply the research knowledge in the participation. This realm is still used in specialized child participation projects such as built environment education, and learning from landscapes.

The fifth realm is the rights realm, or "children as citizens". It focuses on children's right to be protected as participants in city decision-making. This realm is used by city officials 
and international organizations such as the United Nations and UNISEF. Within this realm, child-developed plans and designs can be created for cities. It usually focuses on children's rights more than children's needs in spaces. It is popular in some countries (not specified) because of the support given to it by international organizations such as the United Nations.

The sixth realm is the institutionalization realm, or "children as adults". It involves designing and planning by children but under the boundaries that adults, official clients and authorities create. This realm is normally used in city plans and programs. It creates narrow outcomes based on what children really desire as it ignores aspects of natural and child-centred participation. Children might be picky in their ideas. For example, they may refuse an idea because they are not used to it. It has, however, become the standard method for involving children in children's participation projects.

The seventh realm is the proactive realm, or "participation with vision". In this realm, a combination of research, participation, and action is created to engage children and adults in planning and design. Children are dynamic participants in the process but designers and planners play an essential role. This realm is used to develop participatory designs and plans incorporating children's ideas and needs. This realm is used by children, design professionals, and community organizations. It is not continuously possible in every project, and it requires designers and planners with 
special training and skills in working with children (Francis \& Lorenzo, 2002).

The Ministry of Social Development in New Zealand (2003) provides guidelines for involving children in any decisionmaking process. The United Nations Convention on the Rights of the Child assists New Zealand in recognizing the right of children to participate and be involved according to their age and maturity. It states that children have the right to express their opinions freely and that these opinions should be considered in decisions that affect children. The guidelines include principles that should be followed in any child participation venture. These principles include understanding the importance of listening to the children's voices, choosing the right method of involving children, explaining to the children their role in the process, giving children the choice of not participating if they do not want to do this, and recognizing children as adults in terms of letting them have individual views. The guidelines also suggest barriers that may occur in any child participation process. These include a lack of funds and time, fears about safety and ethics, a lack of knowledge and experience in dealing with children, thinking that children lack the experience to participate, and language and cultural barriers (Ministry of Social Development, 2003).

Feedback is vital to children because it makes them feel their views have been taken seriously. They know that some action has been taken on their suggestions, although these 
might be altered slightly to make them suitable for the process being undertaken. Feedback can be accomplished by holding follow-up meetings, using websites and email, or posting information and copies of reports. According to the Ministry of Social Development in New Zealand, children do not assume all their ideas will be taken up and applied in the decision-making, so there should be no fear of giving feedback. Evaluation is also an important part of the children's participation process, as it enables them to express their ideas and feelings about the process and raise any concerns with it. Children should feel free to express their own thinking and concerns without any adult interruption. Figure 3-8 shows the different methods that could be used in children's participation according to the Ministry of Social Development in New Zealand (2003). Table 3-2 summaries the ways to involve children in the design process and decision-making. 


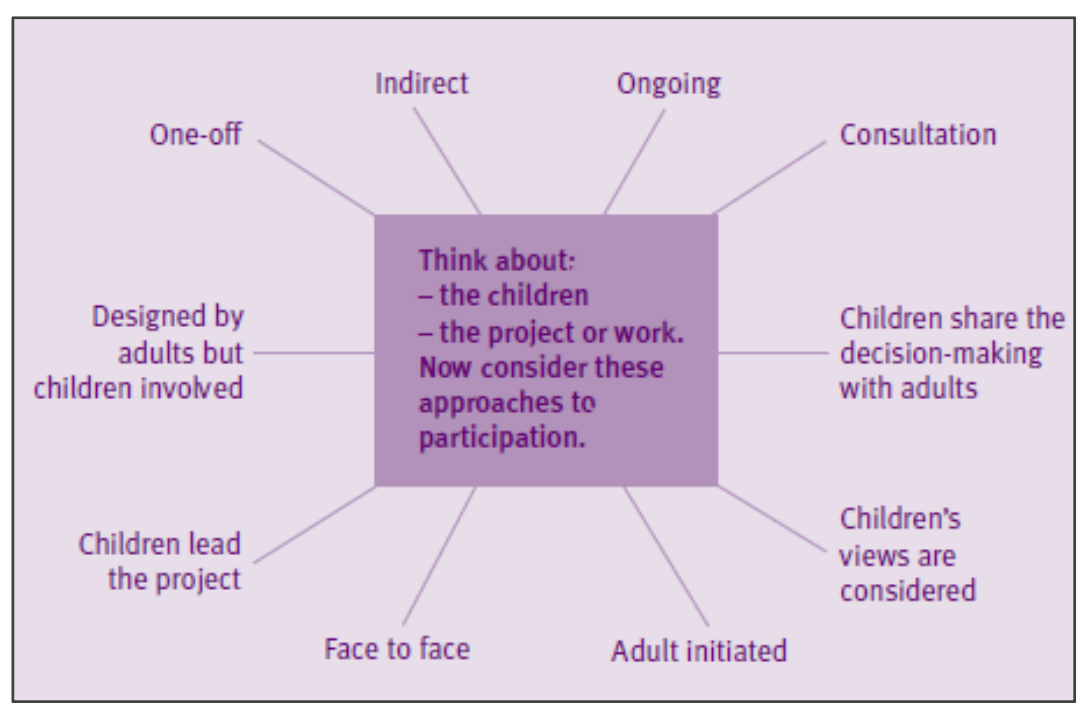

FIGURE 3-6: METHODS FOR CHILDREN'S INVOLVEMENT IN DeCision-MAKing (Ministry of Social Development, 2003).

TABLE 3-2: WAYS TO INVOLVE CHILDREN IN THE DESIGN PROCESS AND DECISION-MAKING.

\section{Methods}

Four levels of action that children can undertake in any design process

(Nesset \& Large, 2004).

\section{Details}

- Observing and studying the impact of a random design on children

- Testing prototypes of the specific design, and again observing children's reactions to these

- Collecting children's thoughts during their participation

- Allowing the children to become a design partner

Three ways of listening to the 'voice' of children

(Mannion, 2007).
- Listening to children who have something to tell adults.

- Dealing with children as complete individuals or citizens 


\begin{tabular}{|c|c|}
\hline Methods & Details \\
\hline & $\begin{array}{l}\text { - Treating children as a minority group } \\
\text { struggling to be heard and be socially included } \\
\text { while still children. }\end{array}$ \\
\hline $\begin{array}{l}\text { Seven Realms of } \\
\text { designing with children } \\
\text { (Francis \& Lorenzo, 2002). }\end{array}$ & $\begin{array}{l}\text { Children as planners, designers for children, social } \\
\text { science for children, children as learners, children as } \\
\text { citizens, children as adults, and participation with } \\
\text { vision }\end{array}$ \\
\hline $\begin{array}{l}\text { The Ministry of Social } \\
\text { Development in New } \\
\text { Zealand guidelines } \\
\text { (Ministry of Social } \\
\text { Development, 2003). }\end{array}$ & $\begin{array}{l}\text { - Understanding the importance of listening to } \\
\text { children's voices } \\
\text { - Choosing the right method of involving } \\
\text { children } \\
\text { - Explaining to children their role in the process } \\
\text { - Giving children the choice of not participating } \\
\text { if they do not want to do this } \\
\text { Recognizing children as adults in terms of } \\
\text { letting them have individual views }\end{array}$ \\
\hline
\end{tabular}

\subsubsection{PARTICIPATION OF CHILDREN IN DESIGNING CHILD SPACES AND LEARNING ENVIRONMENTS:}

Research has revealed a close relationship between learning environments and learning outcomes. In many cases, students are "passive recipients" of education in "adultcentred" environments (Scaife et al., 1997). New educational theories may encourage new teaching strategies that involve group work and collaborative learning but learning spaces may not provide the necessary features to implement these teaching styles (Bland, 2009). In general, design should be a process shaped by designers and users, who need to work 
together for a successful outcome. In learning environments, students and teachers are considered the main users, yet children are rarely involved in the design process (Scaife et al., 1997). According to Iltus and Hart (1994), the participation of children not only produces a good and appropriate design, but it also leads users, including children, to have a greater sense of responsibility for maintaining the space created. Adults see a place in relationship to its form, function and aesthetics, whereas children see the function(s) of the place more than its aesthetics.

Ignoring children's participation in designing and planning their built environments makes them feel that they have no control over their learning spaces, and consequently, they may not be able to move freely in their built environment. The environment may limit their actions and potential (Said, 2007). Studies show that school designs that involve student participation, through using children's imaginations in the design process, end up with great and innovative ideas. However, children are rarely consulted or involved in the school design process. Children's ideas are unpredictable and often innovative, which can lead to ideas that neither architects nor teachers would have thought of (Bland, 2009). Architects and designers should recognize the importance of children's experiences and thought processes in order to be able to design effective learning spaces. Designing is all about the attitudes of users to built environments (Nair \& 
Fielding, 2007). Perhaps not all children can participate in the design process effectively and some designers may find it hard to deal with children, however, involving students and children in the process of designing learning spaces is fundamental to good learning outcomes (Scaife et al., 1997).

Designs created by architects are usually complete, which leave little or no room for children to change or manipulate the architecture. Such designs may not create a relationship between children and the building. Thus children may not like some places and may not have the desire to go to some buildings, such as school (Said, 2007).

It has been argued that children's decisions about designing learning spaces might be affected by factors from their childhood or by views of schools constructed by adults. However, this latter is not different from any design process as most architects draw on precedents (Clark and Pause, 2012). However, the consideration of children's participation in learning space design and building provides a network of communications which can be "multidimensional" and can recognize a diversity of views and experience. In this way, children from different ages and different backgrounds can be part of the design process (Burke, 2007). Children's physical involvement with architects and designers over designing a place for them gives the children satisfaction and a good experience that stays in their memories. Afterwards, these memories work as a connection between the place and children. Positive 
emotions regarding the place created by these memories provide children with a good opportunity to be creative in their own environments (Said, 2007). Children respond to designed spaces, but their voices in issues regarding material design have, until recently, been ignored. Many adults think that children are not capable of involvement with planning learning spaces. However, there have been, and still are, people who have considered children's views in education and learning environments. Since the 1970s, environmental psychologists like Roger Hart have argued that the ability of children to build, shape, and create their own worlds indicates essential spatial knowledge and natural ability to design. The educator John Holt has argued, "Children are sensitive to space" (Burke, 2007). He said that if adults support child learning and wellbeing, they would design according to children's spatial needs. Pioneering work that involves children has developed from letting children select the colour of the walls and allowing them to participate in the design process to achieve high quality in both functions and aesthetics (Burke, 2007).

Not all children have the capability to participate at the same level and project organisers should choose appropriate methods for each age group. Children should have the opportunity to participate in any stage of the design process, from planning to finishing, via a variety of media, whether verbal, written or visual. Adults who involve children in projects need to be educated about the child's ability to be 
involved and why it is so important. Some adults believe that children should be left alone to generate creative ideas (Iltus and Hart 1994), but children should also have the opportunity to collaborate with people of all ages and types. This collaboration is a phase of interaction between adults and children in the design process. In collaborative designs, it is difficult to acquire equal responses from all participating children. Some children, indeed, may not wish to participate at all. However, it is vital to give all children the same opportunity to participate. Some children, if they wish, can participate in providing comments and evaluating the design ideas. Other involvements could be achieved by drawing competitions, expiations, suggestion boxes, or oriented events. For example, in the design project for a schoolyard in New York, greater involvement was accomplished by displaying a large model with the proposed designs in the main hallway of the same school. Iltus and Hart (1994) suggest allowing each group of children, such as classroom students, to elect a representative, as it is usually difficult to let all children participate equally in model building, simulation, or collage work. The representative's role is to deliver their classmates' ideas to design meetings and report back to their classmates the results and outcomes of the meetings. It is vital to free children from the limitations of their experience with traditional designs. This may require brainstorming sessions that could include presentations or films to break into the logic of child thinking. Different techniques could be used 
when designing with children, such as modelling, collective drawings, photo-based collage making, design games, and full-size simulations (Iltus \& Hart, 1994).

There are studies of using different methods to engage children in the design process of learning environments. In 2002, in the UK, the educators Peter Moss and Alison Clark established an approach that enabled children, with their teachers, parents, and architects, to participate in visual conversation about designing learning environments (Burke, 2007). In 2005, in Italy, the research analyst Michele Zini developed another approach for enabling children and adults to collaborate in decision-making over learning environments. Zini let children aged three years, on their first day at infant school, arrive into an open, empty space and then create an internal layout for using the space. Zini's plan was to enable the children to "dress" that space with the adults through collaborative work. Much earlier, in 1913, in Geneva, the psychologist Jean Piaget was provided with a school without a classroom for one of his projects. Piaget completed his observation of children in this school where children were encouraged, with just materials and equipment, to move freely through the environment. Children made decisions about how the space could be used and what activities could happen in this space (Burke, 2007). According to (Said, 2007), kindergartens are an example of the domination of adults in the designing of child spaces, and these generally limit children to indoor environments 
only occasionally allowing them to involve themselves with the outdoors. Inside the built environments, children engage with a variety of furniture and plastic toys in a "controlled micro-climate" where the light, temperature, and humidity are the same for their whole stay inside the building. This situation contrasts with Piaget's theory of childhood development, which says that children are energetic and motivated learners and the outdoors offers children the opportunity to move more freely than inside the built environment. In the outdoors, children engage with vegetation and animals. Children can notice the change in temperature, daylight, wind, and the presence of rain or snow, which makes them realize that nature is not humanmade. Accordingly, children perceive the architecture as buildings (manmade) and landscape (natural), which means that they may think that architecture is different from the landscape (Said, 2007).

The architect Water Hill presented a list of ideas proposed by children aged 5 to 12 years through meetings and discussion sessions. He recommended understanding the relationship between "design, learning, and well-being". Some of the ideas proposed were "put the desks in the halls so we can use the rooms", "make it so we can walk around because we were born free", "a rocking horse to sit on when you need to think and a bed to read in it", and "it has a sign on everything that says PLEASE TOUCH" (Burke, 2007, pp. 361-366). Many schools and classrooms need to "re-invent" 
or "redefine" themselves, but teachers, architects, and decision makers are not sure how this can happen. Schools are places where adults are in charge and have control over children. Although child involvement is very important for creating successful learning environments, many teachers think that it could be hazardous if teachers and children share power in schools (Burke ,2007).

In 2009, in the "International Visual Methods" conference, Dr. Derek Bland discussed the progress of a project that used children's drawings of their learning environments as the primary data source and how useful these could be. He claimed that students' drawings were valuable tools, which could be used for providing information when assessing children's learning environments. The project involved students from year 5/6, aged 9-11 years, in a number of primary schools in Australia. Students were invited to submit drawings and up to 200 words of text explaining their ideas for their ideal learning spaces. Students and teachers were advised that the drawings could be about any learning spaces, such as classrooms, school grounds, or even completely imaginary spaces. The project used children's drawings as the primary data source because, according to Bland (2009), there is much evidence that shows how useful these could be. Drawings could be valuable tools for providing information for assessing children's learning environments, as children's drawings have a strong power that affects the "educational ecology" of schools. In students" 
drawings, there were a number of imaginative ideas for learning environments such as a flying carriage, a hot air balloon, and being inside a video game. Some students suggested nature as a learning space, such as beaches and rain forests. Some ideas were environmental, such as using solar power and direct sunlight (Bland, 2009). In 2010, in the AARE Annual Conference in Australia, Dr. Derek Bland discussed the same project, after its completion. Bland pointed out that the main conclusions of the project was that students' drawings emphasized that the learning process should be fun and learning spaces should be imaginative and eco-friendly. Students stressed colour and excitement in learning environments, and the children wanted to learn in collaborative and "friendly social" environments (Bland, 2011)

The older work of Professor Kim Dovey and Dary LeGrew in 1979 also involved children's drawings. This work was about living spaces, not learning spaces as with Bland's work, but living spaces are also important as spaces children live in. Dovey, then an architecture research student, and Dary LeGrew, a lecturer in architecture at the University of Melbourne, also completed a workshop asking children to draw the spaces they live in, imagine, and like. The workshop included children aged three to twelve years who were living in Melbourne. Children's drawings were the reactions to one of three requests: "The place in which you live", "your favourite space", and "best possible place in the 
world". As the distinction between real and imaginary worlds is not strong in children, it was difficult to distinguish responses for different requests from each other. Children produced drawings that, in some cases, included realistic and imaginary elements. Dovey and LeGrew analysed the drawings according to views, important elements, imaginary places, and anthropomorphism. In terms of views, children up to age four drew highly "figurative elevations". Their focus was on the outlines that shape windows and doors and not on forms, scales, and spatial relationships. From the age four to eight or nine, children start to draw in "adult-mode". However, they still mix up elevations, sections, plans and perspectives. Elements in perspective appear after age seven. Flattened panoramic views also emerged in some drawings. For example, one child drew all the walls of a room folded out. In terms of important elements, children focused on elements that were important to them such as doors, windows, and roofs (ceilings) inside built environments. External elements such as sun, birds, clouds, pools, trees, flowers, playgrounds and roads also appeared as very important elements in children's drawings. Sometimes these external elements dominated the internal elements in the drawings. Also of note is that furniture does not appear in this list of important elements. In terms of imaginary places, children's drawings of these have a tendency to be vertically separated from the real world in order to create an "upperworld" and an "underworld". For example, the tree house 
appeared in many drawings, and some children drew some imaginary elements, such as flying foxes, slides, ropes, and ladders, to reach the upper-world. Finally, in terms of anthropomorphism, some children drew various elements as body organs, for example, drawing the house as a face, windows as eyes, and the door as a mouth. Dovey and LeGrew believe that the drawings from the workshop are "a source of understanding deeper than (they) could induce by attempting further explanation". They concluded the imagination of children is a quality needed in adult environments and spaces and in designers' work (Dovey \& LeGrew, 1979).

However, consulting children about their ideas through the use of drawings does not give them the opportunity to give feedback about the use of their ideas. Engaging students in design by use of drawings also has two other disadvantages. The first is that some children have limited drawing ability, and the other that children's drawings are open to adult interpretations. The second downside could be avoided, as suggested by Iltus and Hart (1994), by the help of teams of architecture students who could discuss the children's drawings after completion without any interpretation, as they are not part of the design team but can understand design ideas from the drawings.

In 2010, Mary Featherston completed a design research project on participation in school communities between educators and designers in addition to consulting young 
people. The aim of the project was to find out how design can support creativity in learning spaces. Although each school participating in the project had a different inspiration behind proposed change, they all believed that the design of physical learning environments was vital to support learning and teaching processes. All schools prioritized the good connection and relationship between people and learning and the "virtual realms". For the project, students and teachers gathered in groups, forming an educational "neighbourhood". Each group discussed experiences and needs. Some required an intimate, quiet setting, while others wanted an open, clear area, and some needed practical equipment, like sinks. After finalizing and grouping all the needs, a group of named settings that could support a wide range of experiences emerged. The settings included Entry/Gallery, Lounge and Games, Reading, Study Commons, Small Group Discussion, Whole Community Gathering Space, Studio Lab, and Staff Facility (Featherston, 2010).

Another project that involved students was a programme called "the ECO-Cubby programme" that gathered architects with students in schools to let children develop an understanding about built and natural environments and sustainability. The programme was for children in kindergartens and primary schools in Victoria, Australia. Children in the programme were engaged in designing a cubby house by themselves and for themselves through 
collaborative work guided by professional architects and one teacher from the children's school. The first application of this programme was in 2009. It was a pilot study that is still running. The programme encourages children to think about solving environmental problems. It aims at engaging sustainability with curricula. It also helps students to understand how their bodies fit in a space, which can help to develop a sense of built environments in children's minds.

The ECO-Cubby design process includes an architect from the ECO-Cubby programme, one teacher, and children. They work through several stages (concept, design, documentation, and modelling). The feedback from students, teachers, and architects about this programme was "overwhelmingly positive" (Boucher, 2011). An example of the ECO-Cubby programme is Bundalagush Primary School. This primary school started applying the programme in 2009, working with two architects from the ECO-Cubby programme. Students learned many concepts about scale. First, students worked in groups measuring playground settings. Secondly, students created models of these settings at 1:20 scale. Next, the children measured themselves and created models of themselves at the same scale. This exercise enabled children to understand the relationship between different sizes of settings and structures and compare these with their own bodies (Boucher, 2011). 
A more recent project involving children in the design process of their spaces was completed by Charles Barrie in 2012, as a component of his Master's thesis work. The main aim of the project was to use participatory design in designing a primary school garden. Barrie started the work by conducting a workshop about garden design with eight representative students in a New Zealand primary school. The children were deliberately selected by the school as not being the top achievers in the class. Other participants in the project included the head teacher, the head principal, the school caretaker, a builder, an architect, and a landscaper but these were only involved at other stages of the project. The workshop included exploring the garden and a brainstorming session. Barrie had produced plans with the outline of the garden so the students could suggest new garden designs and try them out on the plan. Students produced a group of ideas, and some of the common ideas included adding fruit trees, creating stepping-stones, and creating three different levels in the garden. The garden was later reviewed by the architect who helped the children draw up a detailed plan to scale that incorporated their original ideas. A local builder then helped the children to construct the hard elements of the garden (the paving, seating and raised beds) and the landscaper helped the children with the planting. Throughout Barrie was the enabler bringing the various stages of the project together. All adults gave their time voluntarily to this project (Barrie, 2012). At the end the participating students were given a 
special award at the school prize-giving for their work on the garden project.

\subsubsection{Discussion}

As users of learning environments, students should have the right to participate in the design process of their learning environments. The literature provides a number of standards and ways to conduct participatory design with children. Thus, designers and architects involved with school design do have access to the base knowledge to complete participatory designs in learning environments. The variety of methods provided by the literature offer children the opportunity to express their thoughts in different ways according to their preferences. This engagement with children can also be part of the learning process in school, rather than additional to it. The studies about children's participation in general and in learning environments specifically also prove the ability of children to participate in decision-making. However, the examples also show that this process does take more time, especially for the adults involved. However, with all its advanatages and with the available methods there should be more children being involved in the design of their own learning environments.

\subsection{EXAMPLES OF PARTICIPATORY DESIGN IN LEARNING ENVIRONMENTS}

This section provides two examples of the design process for two projects that involved users throughout the process. 
One example is school design and the other is learning studios design.

In 2005, the Sorrell Foundation in the United States designed and installed a model called "joined up design for schools". The model suggested that children as clients best understand their needs. This model, which was installed in schools, had a process that was started by a head teacher selecting 20 students to form a "client team" and a teacher to support this team. This team then worked with one of the best architects in the country, proposed by the Sorrell Foundation. The model involved four stages:

a) The Sorrell Foundation presented a seminar on the nature of the design,

b) The client team had a number of brainstorming sessions to produce a list of common issues and three challenges,

c) The client team prepared a brief including a statement on the chosen design style, and

d) Client team and the designer had several meetings over several months to develop the final concept.

At the end, the designer presented the final design to the client team, and once the client team was satisfied, to the head teacher. The Sorrell Foundation started a pilot model in 2001 with seven primary and secondary schools. In 2002, the Department for Education and Skill provided support to install the model in 100 schools over three years. The "joined up design for schools" model was successful in terms of 
achieving its aims and goals. However, it did not encourage consideration about the reasons behind designing a school a certain way (Burke 2007).

The other example is "Inside Out", which was a project about refurbishing a learning space to support contemporary thinking about children and learning in Australia. The project involved students, staff, and parents, in addition to the designer. Wooranna Park Primary School (WPPS) was selected for completing this project, as the staff was already committed to applying "educational innovation". The principal and staff in WPPS believed that students had the right to be in high quality learning environments in addition to receiving high quality pedagogy. The school has been partially renovated since 1996. Internal walls have been removed and "noninstitutional" furniture introduced to create active and collaborative learning environments for students and teachers.

However, one area of the school was not performing as projected. The area was a combined group of 100 students from Grade 5/6, aged 9-11 years, in six typical classroom spaces (the Unit). The Unit was furnished with tables and chairs, which made it difficult for teachers to work on a wide range of groupings. The openness of the area also made it difficult for traditional teaching styles, in addition to other teaching styles such as the team teaching approach. The project included the design of all physical environment 
layers: existing spaces, furniture, and loose items. The project did not cover indoor/outdoor learning, as the budget was not large enough to do this (Figure 3-9).

The participants of the Inside Out project were the school principal Ray Trotter, 100 students aged 10-12 from different ethnic and social backgrounds, a team of four teachers and two assistants who had worked in the Unit for four years, and the interior designer Mary Featherston, who was experienced in designing interactive learning spaces and who was inspired by the educational project of Reggio Emilia in Italy (Featherston 2006). Reggio Emilia is an educational theory created by the primary school teacher, later professor, Loris Malaguzzi that focuses on analysing children's values so these can be respected in educational curricula (Driscoll \& Nagel, 2012). The Inside Out project started in 2005. All participants were involved in the project process from the analysis of needs to assessment of existing environments. The initial meetings revealed that children have the ability to examine their everyday spaces. Students were asked, "What is it like to be a student at WPPS?" The responses came out as texts and drawings completed by students, which focused mainly on the importance of play and friendship and generally on activities, learning, and working hard. Students and staff were asked about experiences and needs. The designer also discussed design ideas with students and staff. The new design included fifteen dedicated settings. Each setting supports a certain 
activity and all settings are connected in a flowing space. The new arrangement was designed to be a busy environment, full of people, activities, and movements. There is flexibility within the small area in the design. For example, the drama space can be converted from a totally blacked-out space for audio/visual presentation to an open space for performing, movement, and music. There are connections and multipurpose features in the new settings. For example, the lockers are for tidy storage, display units (as they have surfaces for display), and for spatial partitions (Featherston 2006). 

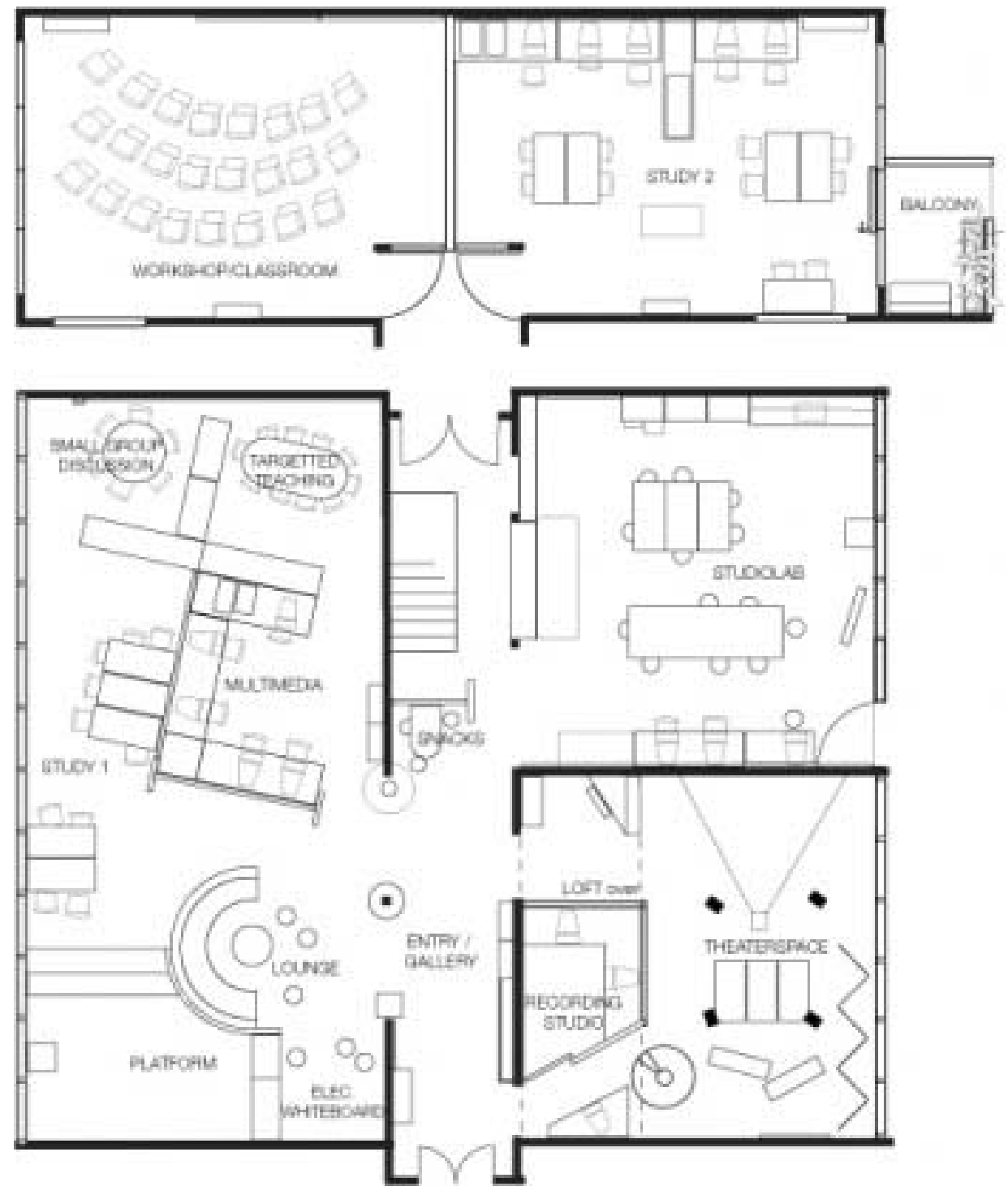

Figure 3-7: THE FLOOR PLAN OF THE INSIDE OUT PROJECT (FEATHERSTON, 2006).

\subsubsection{DISCUSSION}

The two examples described how the projects involved users, teachers and students in the design process in two different countries. Unfortunately, there are as yet no studies 
that discuss user involvement in designing interior learning environments in New Zealand.

The two studies used similar methods of conducting meetings and discussions with the users with differences in the details of these. Both involved users from the early stages of generating ideas and the process did not just involve designing floor plans and then asking users to comment on these. This is very important as it shows how involving users from the early stages could mean ending up with successful designs that meet with user's needs. These examples could also be used as inspiration for other projects for learning environments.

\subsection{Post occupancy eVAluations}

Zimring and Reizenstein (1980) state "Post-occupancy evaluation (POE) is defined as examination of the effectiveness for human users of occupied, designed environments". POE studies the physical designed environments with a special focus on how these environments affect or are affected by human use (Zimring \& Reizenstein, 1980). Generally, it aims to identify and evaluate acute issues in the performance of an existing, often relatively new, building (Preiser, 1995). POE has very important benefits for designers, such as working towards continuous improvement in the environments they design, often through listing the key points of critique of the building so as to address and improve these in following projects (Zimmerman \& Martin, 2001). Hadjri \& Crozier 
(2009) mention four advantages of conducting POE. It can help in creating building-behaviour research, providing information or examples for pre-design programming for new projects, assessing buildings to improve them and so keep on line with contemporary goals, and creating a set of standards and measurements with which to assess other projects (Hadjri \& Crozier, 2009). POE can be completed using different approaches. Hadjri \& Crozier (2009) suggest a group of such approaches for the building being evaluated. These contain reviews based on quantitative technical assessments, discussions using discursive techniques such as focus groups and interviews, questionnaires, documents of the process and techniques used to collect feedback, or a package using more than one method or approach to generate the POE (Hadjri \& Crozier, 2009).

POE is not conducted in most projects for various reasons. Designers and architects are never paid to go back and evaluate their built projects. In any standard practice the job of the designer or architect normally ends with handing over the building and a defects inspection after 6 months that only looks at the building fabric, not the building in use. This fails to recognise the concept of continuous involvement in the building after the construction is finished. In addition, there could be a communication barrier between professionals and users of a building when it comes to defining a building's pros and cons. Miscommunications 
could happen as some users do not have experience of architectural language (Zimmerman \& Martin, 2001).

In terms of school buildings, this research is largely focussed on the link between learning environments and student learning outcomes and teachers' work effectiveness. Ideally, school buildings should be designed through first building a relationship between architects and users (including students, teachers, and parents). Involving users in the design process is a vital part of achieving good school designs. Assessing school buildings via POE is also a part of the design process that needs user involvement. POE in school buildings could include learning performance and social behaviour in addition to the physical aspects that affect learning and teaching, such as spatial configurations, indoor air quality, ventilation, thermal comfort, light and noise (Zhang \& Barrett, 2010).

Zhang \& Barrett (2010) provide an example of POE of primary schools in Manchester, England. The POE mainly focused on the perception and experience of teachers and students of their school buildings in terms of the thermal, lighting, acoustic, flexibility and functional performance aspects. The POE covered five primary schools with students 3-11 years old. It included questionnaires that aimed to gain information about user experience and perception of school buildings, interviews with head teachers to explore the responses and attitudes to the questionnaires in more depth, workshops that were run in 
each school. They involved staff and local representative to collect basic information about the building designs and the problem experienced during the design process, and finally observations on how the schools were used, including taking photographs of the different parts of the school. The main results from the POE were the essential nature of making physical spaces that are comfortable in terms of thermal, visual and acoustics factors for a comfortable and productive environment. For example the questionnaires revealed how teachers and students want as much natural light as possible to create good learning environments for a better learning process. The POE also indicated that classrooms were the most spaces used within the schools. Thus these learning spaces should be given priority when it comes to both design and POE. Other spaces such as corridors, the library, and the gym are important, but not as much as classrooms. The POE also revealed that the better and more effective learning environment designs existed in schools where users were involved in the different stages of the design process.

\subsubsection{Discussion}

Post Occupancy Evaluation is an important part of the design process although professionals do not normally get paid to do it. Its benefits, in terms of the usefulness of what is learned, cover both the existing buildings and future projects. Thus, it should be given more consideration, especially when it comes to learning environments, as the users of these change over time. Learning environments are 
places that serve different types of users; young students and adult teachers, males and females, in addition to the fact these users change every few years. The environments, then, should be able to serve the different needs of different generations. POE undertaken as users change could help in improving small parts of the design to make it suitable and contemporary. At the same time, POE does not conflict with the fact that users should be involved and included in the design process. In fact POE could not be properly completed without the involvement of users, as the definition of POE above focuses on the effects of the building on the users.

The conclusions from the POE example mentioned above create a huge motivation for this research to continue investigating the involvement of users in the design process of learning environments. It also reinforces the fact that POE and participatory design are two concepts that share similar purposes and aims, such as achieving better environments through the involvement of users of these.

\subsection{CONCLUSIONS}

Involving users in the design process is a vital issue. Through participatory design, designers could produce better designs and products, with users contributing by providing information about their needs and requests. There are also many methods for doing participatory design, with the need to use the right method for the right project. In the design of learning environments, teachers and students are the main users. Teachers, as adult clients, can be involved in 
the design process without the need for special rules or guidance. Teachers also change the internal layout of their learning environments by themselves, without the need for professional supervision. Children, on the other hand, need special requirements to be involved in any decision-making. Thus, involving children in designing learning environments requires not just research but studies of real projects. This chapter provided a number of examples and methods for involving students in designing learning environments but as yet these seem too few to draw reliable conclusions on the best way to go about participatory design with children.

After collecting the necessary information about design and the design process, learning environments in New Zealand must be discussed in the same manner. The following chapter provides information and studies on the design and design process of New Zealand learning environments. 


\section{CHAPTER 4: DESIGNING LEARNING ENVIRONMENTS IN NEW ZEALAND}

The aim of this chapter is to investigate the design of learning environments in New Zealand with a special focus on primary schools. This chapter gives a description of the studies and research undertaken on such learning environments. Some of these are for studies by other researchers and others are information analysed specifically for this thesis in order to create a wider view of designing learning environments in New Zealand.

The chapter is divided into three main sections. The first section analyses a group of prize-winning primary schools in terms of their design. This section focuses on what is mentioned about these schools that has made them eligible for a prize in order to create an understanding of successful learning environment designs in New Zealand. The second section discusses research and work completed by the Ministry of Education and is arranged in four subsections: a survey completed by the Ministry of Education on designing schools in New Zealand, the guidelines that the Ministry provides for schools and architects for designing learning environments, the examples that the Ministry provides to go with these guidelines, and a pilot study completed by the Ministry to introduce learning studios into New Zealand schools. The last section looks at various completed studies 
that relate to learning environments in New Zealand, and consists of five studies of New Zealand schools.

Most discussion and comments will be found in chapter 8, as it involves comparison with the results of the research undertaken for this thesis.

\subsection{PRIZE-WINNING PRIMARY SCHOOLS IN NEW ZEALAND}

The table provided below has been compiled to show primary schools in New Zealand that received the 2012 New Zealand Institute of Architects (NZIA) and other awards, on the assumption these are supposed to represent the best designed schools in the country. The analysis of the information provided about these schools, mostly coming from the NZIA website and supplementary information from architects' websites, indicates that these schools and their architects have focused heavily on the external layout of the building and the interior design of main halls, libraries, and school entrances. Only three schools out of 22 that won awards discussed the interior design of the classrooms, and in only 6 instances were there pictures of the classroom interiors. Table 4-1 gives details about these schools, their outdoor and indoor areas, and some photographs. 
TABLE 4-1: INFORMATION ABOUT THE 22 PRIZE WINNING PRIMARY SCHOOLS IN 2012 IN NEW ZEALAND.

\begin{tabular}{|c|c|c|c|c|c|c|c|c|}
\hline $\begin{array}{l}\text { The name of } \\
\text { the school }\end{array}$ & $\begin{array}{l}\text { Type of } \\
\text { work }\end{array}$ & Architects & Awards & $\begin{array}{l}\text { Outdoor design } \\
\text { information }\end{array}$ & Indoor design information & Classroom Interiors & Exterior images & Interior images \\
\hline $\begin{array}{l}\text { Te Totara } \\
\text { Primary School }\end{array}$ & New school & $\begin{array}{l}\text { Chibnall } \\
\text { Swann } \\
\text { Team } \\
\text { Architecture } \\
\text { Ltd }\end{array}$ & $\begin{array}{l}\text {-Resene } \\
\text { Colour } \\
\text { Award } \\
\text { - NZIA } \\
\text { Award }\end{array}$ & $\begin{array}{l}\text { The exterior design is } \\
\text { shaped by strong lines } \\
\text { and bold colours }\end{array}$ & $\begin{array}{l}\text { The interior plan of the } \\
\text { school is formed from } \\
\text { multi-purpose teaching } \\
\text { spaces, based around } \\
\text { rooms of variable size } \\
\text { arranged in cluster blocks. } \\
\text { Materials selection was } \\
\text { based on noise control } \\
\text { aspects. } \\
\text { Neutral colours were used } \\
\text { with primary colours. }\end{array}$ & & & (DLA Archite \\
\hline $\begin{array}{l}\text { Opunake } \\
\text { Primary School } \\
\text { - } \\
\text { Te Putahi Ako } \\
\text { Canopy }\end{array}$ & Canopy & $\begin{array}{l}\text { Chapman } \\
\text { Oulsnam } \\
\text { Speirs } \\
\text { Limited }\end{array}$ & $\begin{array}{l}\text { - NZIA } \\
\text { Award }\end{array}$ & $\begin{array}{l}\text { The project was } \\
\text { installing a canopy to } \\
\text { link two classrooms } \\
\text { outdoors and provide } \\
\text { a shaded area. }\end{array}$ & & $\begin{array}{l}\text { The project included } \\
\text { joining two classrooms } \\
\text { together with interior } \\
\text { refurbishment } \\
\text { (Chapman Oulsnam } \\
\text { Speirs, 2012b). }\end{array}$ & & $\begin{array}{l}\text { (Chapman } \\
\text { Speirs, 2012b). }\end{array}$ \\
\hline $\begin{array}{l}\text { Glenview } \\
\text { Primary School } \\
\text { - New Library }\end{array}$ & New library & $\begin{array}{l}\text { Peddle } \\
\text { Thorp } \\
\text { Architects } \\
\text { (Hamilton) } \\
\text { Ltd }\end{array}$ & $\begin{array}{l}\text { - NZIA } \\
\text { Award }\end{array}$ & $\begin{array}{l}\text { The exterior design is } \\
\text { shaped by strong lines } \\
\text { and bold colours to } \\
\text { create an attractive } \\
\text { look for the new } \\
\text { library }\end{array}$ & $\begin{array}{l}\text { The library space is a } \\
\text { double height volume with } \\
\text { glass walls. } \\
\text { The library space is } \\
\text { separated from single } \\
\text { storey spaces by a curved } \\
\text { dividing wall. }\end{array}$ & & & 酰 \\
\hline
\end{tabular}




\begin{tabular}{|c|c|c|c|c|c|c|c|c|}
\hline $\begin{array}{l}\text { The name of } \\
\text { the school }\end{array}$ & $\begin{array}{l}\text { Type of } \\
\text { work }\end{array}$ & Architects & Awards & $\begin{array}{l}\text { Outdoor design } \\
\text { information }\end{array}$ & Indoor design information & Classroom Interiors & Exterior images & Interior images \\
\hline $\begin{array}{l}\text { Woodstock } \\
\text { Primary School } \\
\text { - } \\
\text { New Entry \& } \\
\text { Library } \\
\text { Computing } \\
\text { Additions }\end{array}$ & $\begin{array}{l}\text { New Entry } \\
\text { \& Library } \\
\text { Computing } \\
\text { Additions }\end{array}$ & $\begin{array}{l}\text { Peddle } \\
\text { Thorp } \\
\text { Architects } \\
\text { (Hamilton) } \\
\text { Ltd }\end{array}$ & $\begin{array}{l}\text { - NZIA } \\
\text { Award }\end{array}$ & $\begin{array}{l}\text { The new entry } \\
\text { provides a sheltered } \\
\text { gathering and drop-off } \\
\text { point for students. The } \\
\text { outlook of the school } \\
\text { was designed with } \\
\text { bold colours, } \\
\text { impressive scale, and } \\
\text { strong horizontal lines } \\
\text { to welcome and lead } \\
\text { visitors to the new } \\
\text { entrance. }\end{array}$ & $\begin{array}{l}\text { The new work included } \\
\text { extending and refurbishing } \\
\text { the computer suite and the } \\
\text { library. }\end{array}$ & & 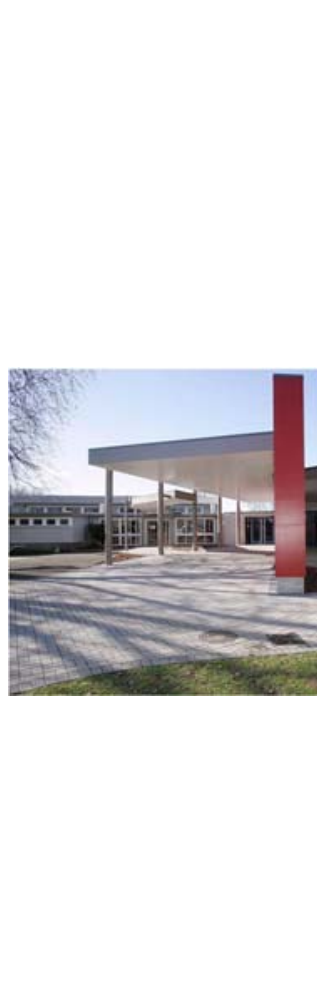 & \\
\hline $\begin{array}{l}\text { Remarkables } \\
\text { Primary School }\end{array}$ & New School & $\begin{array}{l}\text { Babbage } \\
\text { Consultants } \\
\text { Limited }\end{array}$ & $\begin{array}{l}\text { - NZIA } \\
\text { Award } \\
\text { - Merit } \\
\text { award } \\
\text { from the } \\
\text { Property } \\
\text { Council } \\
\text { New } \\
\text { Zealand } \\
\text { - Rider } \\
\text { Levett } \\
\text { Bucknall }\end{array}$ & $\begin{array}{l}\text { The building is in a } \\
\text { crescent shape, with } \\
\text { teaching spaces open } \\
\text { to a recreation and } \\
\text { play space. } \\
\text { The natural colours of } \\
\text { the materials reflect the } \\
\text { concept that the } \\
\text { buildings are part of } \\
\text { the landscape }\end{array}$ & $\begin{array}{l}\text { The project pays careful } \\
\text { attention to the acoustic } \\
\text { treatment in order to reach } \\
\text { the MoE requirements for } \\
\text { noise levels. Double glazed } \\
\text { windows were installed } \\
\text { for sound insulation } \\
\text { (Babbage Consultants } \\
\text { Limited, 2012). }\end{array}$ & & 4a ${ }^{2}$ it & (Babbage \\
\hline
\end{tabular}




\begin{tabular}{|c|c|c|c|c|c|c|c|c|}
\hline $\begin{array}{l}\text { The name of } \\
\text { the school }\end{array}$ & $\begin{array}{l}\text { Type of } \\
\text { work }\end{array}$ & Architects & Awards & $\begin{array}{l}\text { Outdoor design } \\
\text { information }\end{array}$ & Indoor design information & Classroom Interiors & Exterior images & Interior images \\
\hline & & & $\begin{array}{l}\text { Property } \\
\text { Industry } \\
\text { Awards } \\
\text { (Babbage } \\
\text { Consultant } \\
\text { s Limited, } \\
2012 \text { ). }\end{array}$ & $\begin{array}{l}\text { (Babbage Consultants } \\
\text { Limited, 2012). }\end{array}$ & & & & \\
\hline $\begin{array}{l}\text { Kaponga } \\
\text { Primary School }\end{array}$ & $\begin{array}{l}\text { New } \\
\text { Library and } \\
\text { Hub }\end{array}$ & $\begin{array}{l}\text { Chapman } \\
\text { Oulsnam } \\
\text { Speirs Ltd }\end{array}$ & $\begin{array}{l}\text { - NZIA } \\
\text { Award }\end{array}$ & $\begin{array}{l}\text { The design of the new } \\
\text { library is shaped by the } \\
\text { main protective } \\
\text { circular wall. }\end{array}$ & $\begin{array}{l}\text { Indoors, a sheltered area } \\
\text { connects the } \\
\text { administration and senior } \\
\text { areas, providing activity } \\
\text { spaces for learning and } \\
\text { playing. }\end{array}$ & & & $\begin{array}{l}\text { (Chapman } \\
\text { Speirs, 2012a). }\end{array}$ \\
\hline $\begin{array}{l}\text { Avondale } \\
\text { Primary School } \\
\text { - Christchurch }\end{array}$ & New School & $\begin{array}{l}\text { Sheppard } \\
\text { and Rout } \\
\text { Architects } \\
\text { Ltd }\end{array}$ & $\begin{array}{l}\text {-Colour } \\
\text { Award } \\
\text { - NZIA } \\
\text { Award }\end{array}$ & & & $\begin{array}{l}\text { The project includes } \\
\text { well-designed } \\
\text { classrooms and strong } \\
\text { materials. }\end{array}$ & & \\
\hline $\begin{array}{l}\text { Horsham } \\
\text { Downs } \\
\text { Primary School } \\
\text { Development }\end{array}$ & New school & $\begin{array}{l}\text { Peddle } \\
\text { Thorp } \\
\text { Architects } \\
\text { (Hamilton) } \\
\text { Ltd }\end{array}$ & $\begin{array}{l}\text { - NZIA } \\
\text { Award }\end{array}$ & & & & & \\
\hline
\end{tabular}




\begin{tabular}{|c|c|c|c|c|c|c|c|c|}
\hline $\begin{array}{l}\text { The name of } \\
\text { the school }\end{array}$ & $\begin{array}{l}\text { Type of } \\
\text { work }\end{array}$ & Architects & Awards & $\begin{array}{l}\text { Outdoor design } \\
\text { information }\end{array}$ & Indoor design information & Classroom Interiors & Exterior images & Interior images \\
\hline $\begin{array}{l}\text { Flanshaw Road } \\
\text { Primary School }\end{array}$ & $\begin{array}{l}\text { New junior } \\
\text { block }\end{array}$ & $\begin{array}{l}\text { Xsite } \\
\text { Architects } \\
\text { Ltd }\end{array}$ & $\begin{array}{l}\text {-NZIA } \\
\text { Award } \\
\text {-Resene } \\
\text { colour } \\
\text { Award } \\
\text { (Resene } \\
\text { Total } \\
\text { Colour } \\
\text { Award, } \\
\text { 2012). }\end{array}$ & $\begin{array}{l}\text { The new design is } \\
\text { based on existing } \\
\text { buildings on the site } \\
\text { with high-level clear } \\
\text { glass windows that } \\
\text { allow cross-ventilation } \\
\text { and south natural } \\
\text { light. The outdoor } \\
\text { contains sheltered } \\
\text { teaching spaces } \\
\text { (Resene Total Colour } \\
\text { Award, 2012). }\end{array}$ & $\begin{array}{l}\text { The interior is refurbished } \\
\text { with multi-coloured carpet } \\
\text { tiles and white paint. } \\
\text { There are sliding doors } \\
\text { that open up classroom } \\
\text { corners (Resene Total } \\
\text { Colour Award, 2012). }\end{array}$ & & & \\
\hline $\begin{array}{l}\text { Ashburton } \\
\text { Borough } \\
\text { School }\end{array}$ & $\begin{array}{l}\text { New } \\
\text { administra- } \\
\text { tion block } \\
\text { and school } \\
\text { hall }\end{array}$ & $\begin{array}{l}\text { Peter } \\
\text { Beaven } \\
\text { Architect } \\
\text { Ltd }\end{array}$ & $\begin{array}{l}\text { - NZIA } \\
\text { Award } \\
\text {-Colour } \\
\text { Award }\end{array}$ & $\begin{array}{l}\text { The new design of the } \\
\text { administration block } \\
\text { extends the existing } \\
\text { building design with a } \\
\text { new, playful design. } \\
\text { The main colour in the } \\
\text { design is the } \\
\text { traditional red of brick } \\
\text { structures. }\end{array}$ & $\begin{array}{l}\text { The administration block is } \\
\text { open to the exterior via } \\
\text { transparent walls to allow } \\
\text { staff and students to } \\
\text { interact. }\end{array}$ & & & \\
\hline
\end{tabular}




\begin{tabular}{|c|c|c|c|c|c|c|c|c|}
\hline $\begin{array}{l}\text { The name of } \\
\text { the school }\end{array}$ & $\begin{array}{l}\text { Type of } \\
\text { work }\end{array}$ & Architects & Awards & $\begin{array}{l}\text { Outdoor design } \\
\text { information }\end{array}$ & Indoor design information & Classroom Interiors & Exterior images & Interior images \\
\hline $\begin{array}{l}\text { Seatoun } \\
\text { School, } \\
\text { Wellington }\end{array}$ & $\begin{array}{l}\text { Relocation } \\
\text { of the } \\
\text { existing } \\
\text { school } \\
\text { building } \\
\text { (Bevin and } \\
\text { Slessor } \\
\text { Architects, } \\
\text { 2012). }\end{array}$ & $\begin{array}{l}\text { Tennent } \\
\text { Bevin } \\
\text { Slessor } \\
\text { Architects }\end{array}$ & $\begin{array}{l}\text { - NZIA } \\
\text { Resene } \\
\text { Colour } \\
\text { Award } \\
\text { - NZIA } \\
\text { Award } \\
\text { - NZIA } \\
\text { local award } \\
\text { (Bevin and } \\
\text { Slessor } \\
\text { Architects, } \\
\text { 2012). }\end{array}$ & $\begin{array}{l}\text { The new design uses } \\
\text { natural materials and } \\
\text { faded pastel colours. } \\
\text { The scale and size of } \\
\text { the building details are } \\
\text { based on child sizes. }\end{array}$ & $\begin{array}{l}\text { The colours of the interior } \\
\text { are bright primary colours } \\
\text { with clear finished ply. } \\
\text { "Some elements are less } \\
\text { successful when art and } \\
\text { architecture blur, but the } \\
\text { whole is a simple story of } \\
\text { the life of elements found } \\
\text { on seashore" (Bevin and } \\
\text { Slessor Architects, 2012). }\end{array}$ & & $\frac{2}{2}$ & 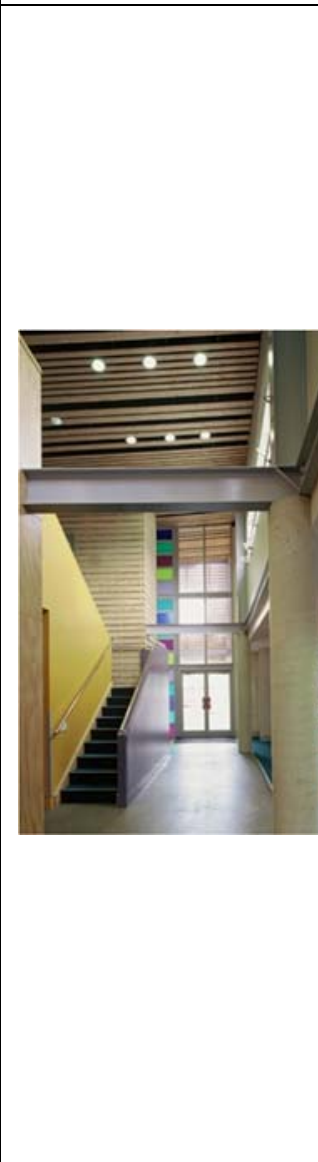 \\
\hline $\begin{array}{l}\text { Taihape Area } \\
\text { School }\end{array}$ & & $\begin{array}{l}\text { Proarch } \\
\text { Architects } \\
\text { Ltd }\end{array}$ & $\begin{array}{l}\text { - NZIA } \\
\text { Award }\end{array}$ & & $\begin{array}{l}\text { The design uses internal } \\
\text { streets to provide internal } \\
\text { circulation for a user- } \\
\text { friendly environment. }\end{array}$ & & & \\
\hline $\begin{array}{l}\text { The Holy } \\
\text { Family School, } \\
\text { Wanaka }\end{array}$ & & $\begin{array}{l}\text { McCoy and } \\
\text { Wixon } \\
\text { Architects } \\
\text { Ltd }\end{array}$ & $\begin{array}{l}\text { - NZIA } \\
\text { Award }\end{array}$ & $\begin{array}{l}\text { The new design of the } \\
\text { building fits well in a } \\
\text { residential street. The } \\
\text { design also provides } \\
\text { external views for the } \\
\text { users. }\end{array}$ & $\begin{array}{l}\text { The design consists of } \\
\text { three learning spaces that } \\
\text { share a resource area. } \\
\text { The design provides } \\
\text { visibility between spaces. }\end{array}$ & & & \\
\hline
\end{tabular}




\begin{tabular}{|c|c|c|c|c|c|c|c|c|}
\hline $\begin{array}{l}\text { The name of } \\
\text { the school }\end{array}$ & $\begin{array}{l}\text { Type of } \\
\text { work }\end{array}$ & Architects & Awards & $\begin{array}{l}\text { Outdoor design } \\
\text { information }\end{array}$ & Indoor design information & Classroom Interiors & Exterior images & Interior images \\
\hline $\begin{array}{l}\text { St Michael and } \\
\text { All Angels } \\
\text { School, } \\
\text { Christchurch }\end{array}$ & & $\begin{array}{l}\text { Wilkie \& } \\
\text { Bruce } \\
\text { Architects } \\
\text { Ltd }\end{array}$ & $\begin{array}{l}\text { - NZIA } \\
\text { Award } \\
\text { - NZIA } \\
\text { Resene } \\
\text { Local } \\
\text { Colour } \\
\text { Award }\end{array}$ & $\begin{array}{l}\text { The building provides } \\
\text { a good connection } \\
\text { between rooms and } \\
\text { with the playground. }\end{array}$ & $\begin{array}{l}\text { Children's learning } \\
\text { environments are } \\
\text { enhanced by the use of } \\
\text { vibrant colours that relate } \\
\text { well to the adjoining } \\
\text { materials and surfaces. }\end{array}$ & & & \\
\hline $\begin{array}{l}\text { Mt Pleasant } \\
\text { School }\end{array}$ & & $\begin{array}{l}\text { Wilkie \& } \\
\text { Bruce } \\
\text { Architects } \\
\text { Ltd }\end{array}$ & $\begin{array}{l}\text { - NZIA } \\
\text { Award } \\
\text {-Resene } \\
\text { Colour } \\
\text { Award }\end{array}$ & $\begin{array}{l}\text { The new design of the } \\
\text { school is light and fun. } \\
\text { The scales used in the } \\
\text { school are appropriate } \\
\text { for young users. }\end{array}$ & $\begin{array}{l}\text { The new project provides } \\
\text { flexible shared common } \\
\text { areas in addition to the } \\
\text { classrooms. } \\
\text { The use of colours helps in } \\
\text { separating zones of } \\
\text { different functions. }\end{array}$ & $\begin{array}{l}\text { The classroom was } \\
\text { designed with playful } \\
\text { colours used in } \\
\text { windows and walls to } \\
\text { create visually } \\
\text { stimulating } \\
\text { environments for } \\
\text { children }\end{array}$ & & \\
\hline $\begin{array}{l}\text { Wilson School, } \\
\text { Takapuna }\end{array}$ & & $\begin{array}{l}\text { Opus } \\
\text { Architecture }\end{array}$ & $\begin{array}{l}\text { - NZIA } \\
\text { Award }\end{array}$ & $\begin{array}{l}\text { The school is built for } \\
\text { special needs. } \\
\text { The design is formed } \\
\text { from timber clad } \\
\text { boxes. }\end{array}$ & $\begin{array}{l}\text { The school includes foyer, } \\
\text { hall and gymnasium in } \\
\text { addition to the classrooms. } \\
\text { Recessed openings and } \\
\text { tinted glazing provide } \\
\text { privacy and at the same } \\
\text { time provide the users } \\
\text { with views of the garden } \\
\text { and the outdoors. }\end{array}$ & & & \\
\hline
\end{tabular}




\subsubsection{DISCUSSION OF PRIZE-WINNING PRIMARY SCHOOLS IN NEW ZEALAND}

The focus on the external design of schools and some internal spaces more than the internal design of classrooms in the prizewinning schools may indicate that the main interests of architects do not include designing classrooms that serve learning and teaching needs although teachers and students spend most of the school day in these classrooms. The designs of these classrooms should, therefore, take priority in designing schools. These prizewinning schools provide preliminary information about the lack of focus on the internal design of learning environments and classrooms.

\subsection{Ministry OF EDUCATION WORK ON THE DESIGN OF LEARNING ENVIRONMENTS}

Before discussing the Ministry work on designing learning environments, the basic system behind recent New Zealand primary school buildings should be discussed.

After 1989, the "Tomorrow's Schools" system was started in New Zealand, promoted by the then Labour government. Under this system schools became responsible for their own maintenance and after 2000, for all relevant property decisions. There is a Board of Trustees (BoT) for each school, which participates in the decisions about school property. Schools are funded with a fiveyear budget to accomplish the necessary maintenance and refurbishments. The Ministry of Education believes that letting schools have the responsibility for their property is a good decision, as the people who are closest to the education environments are the best people to create the optimum 
environments for their students and teachers. The Ministry's role is to make sure that the school has sufficient rooms for teaching and learning and that any project does not go over budget. The Ministry also provides guidelines, examples, and studies to inform schools of good learning environment elements (Sheerin, 2008). The four sections below discuss information provided by the Ministry in different places.

\subsubsection{The "Best Practice in School Design" Study}

In 2004, Bruce Sheerin and Paul Bruce, on behalf of the Ministry's Property Management Group, completed a study called "The Best Practice in School Design". The aim of the study was to investigate the vital elements of good designs in classrooms, schools, and grounds for all schools, including primary schools.

The project proceeded in two stages, a qualitative and semiquantitative phase. The qualitative phase included face-to-face interviews with a total of 20 people, including teachers, students, principals, members of boards of trustees and design consultants. The quantitative phase involved self-completion questionnaires using a telephone methodology for 15 schools to cover a wide range of decile, secondary/ primary, geographic location, and ethnic composition differences. The target group for this phase was a total of 433 people, again composed of teachers, students, principals, members of boards of trustees and design consultants.

The main observation throughout the results of this study was that all the participants considered a quality teaching space to have a vital effect on improving learning outcomes. 
Teachers, students and design consultants acknowledged a similar range of key factors for a well-designed teaching space. These factors included the size and flexibility of the space, a good lighting system, good ventilation, a comfortable temperature, and good acoustics. In primary schools, the participants also focused on having adequate storage space and good quality computer access, whereas in secondary schools they focused on having comfortable seating and good quality desks.

In terms of the size and layout of teaching spaces, the key requirements were having a flexible and changeable room and desk layout, having a personal space on each desk for each student, having a desk layout that minimised chatting between students, and having a good quality of projection onto whiteboards. The space shape and height were also mentioned by teachers and students. They explained that narrow spaces could negatively impact the students' seeing and hearing abilities in regard to the teacher and whiteboard.

For furniture, the report mentioned only the key requirements for seating and desks noted by the participants. These were having durable and good quality furnishing materials, having appropriate sizes and adjustability for seats and tables, not having built-in or fixed furniture, and making sure the furniture is well maintained. The only furniture the report discusses is seats and tables.

Participants considered it vital to receive an allowance for technology. Technology in schools can include computers, electronic whiteboards, and sound management systems. 
Flexibility in technology placement, such as the placement of plugs and modem points in the room, is also a key requirement.

The report includes data from participants about areas outside the classrooms: teacher spaces, specific areas for students, such as quiet spaces and lunch spaces, and the school grounds and playing fields (Sheerin and Bruce, 2004).

In the report, there is also a large section on air quality, temperature, lighting, and acoustics. All respondents understand how important these factors are. Because of the scope of this thesis, in terms of school spaces only classrooms and their environments are discussed in detail here.

The conclusion of the study is that the teaching environment has the potential to improve or weaken student achievements. Teachers and principals agree that learning environments are an important factor for positive student outcomes, ranking after teacher skills and availability of resources.

The report mentions the Ministry of Education's development of a set of guidelines to help schools assess their requirements when it comes to classroom design. The guidelines were planned to be based on the results of questions and information gained from the study interviews and questionnaires. For example, for the size and layout of the teaching space, the guidelines needed to address the space required per student and the shape of the space, with a shape that enables many activities and teaching options being preferable. These guidelines were intended to cover all the factors touched on in the survey questions, including 
temperature, air quality, lighting, acoustics, furniture, and other design elements related to school spaces.

When it came to the design process, members of boards of trustees and school principals encourage collaborative work. They say it is very important to consider students and teachers in the design process and discuss with them their needs and requirements, as they are the people who use the space. The collaborative work should extend, as the trustees explain, from the consultation phase to the final opening ceremony. The principal sources of information about school design are other schools in the region, teachers, design consultants and property managers, research, and the Ministry of Education. On the other hand, trustees' sources are principals, teachers, property professionals, other schools, and research (reading or Internet) (Sheerin \& Bruce, 2004). Figure4-1 is a flow chart reproduced from the report, which sets out their model for the design process for schools, showing where consultation is expected to occur. 


\section{First Stage}

Principals as the decision makers consult teachers and school management, boards of trustees, the community, and students about the requirements, qualities wanted, and funding applications.

\section{Second Stage}

Accordingly, principals with a design consultant develop a plan. People consulted at this stage are fewer than in the first stage (at this stage, the principal will mainly discuss the plan with the school management).

\section{The Brief}

Design consultants are expected to fix ideas on the layout of the building or even start with the details such as the location of the power points.

\section{The Final Stage}

Design consultants direct the schools and try to frame the school's needs. They recommend providing schools with "checklists" developed by the Ministry for the initial thinking and work steps. Design consultants ask schools about certain issues such as "What do you want the first impression of the school to be?", "What does the school stand for?", and "What are our priorities?"

FIGURE 4-1: THE BRIEFING AND CONSULTATION PROCESS ACCORDING to the “Best Practice in School Design” Study. Developed from SHEERIN \& BRUCE (2004, PP. 146- 148). 


\subsubsection{The Ministry of EDUCATION GUidelines For DESIGNING LEARNING ENVIRONMENTS:}

The New Zealand Ministry of Education has prepared guidelines for school principals and boards of trustees in order to let them assess their existing learning spaces, be aware of the features of quality learning environments, and reach the highest possible learning environment for their school.

The guidelines are also intended to make teachers aware of what makes good learning environments, and for designers as part of the brief submitted by the school principal and board of trustees. The Ministry states that quality-teaching environments are important for the improvement of children's learning.

The Ministry guidelines include information about acoustics, air quality and ventilation, heating and insulation, lighting, interior design, function, and aesthetics for learning environments. These elements should work together to produce a high qualitylearning environment. For example, creating environments with good natural lighting must address possible uncomfortable heat gain from the sun. Another example is the clash between having proper ventilation in a space with possible outside noise. According to the Ministry guidelines, learning environments may vary in design and solutions but they all have common features such as a fresh air supply, comfortable temperature, good lighting and being places where students can hear and understand the teacher from all parts of the room. In addition, the layout of learning environments should allow teachers to move 
about easily, be suitable for different teaching methods, give enough personal space for each student, have special spaces for specific activities, and be safe and comfortable. The furniture in learning environments should be ergonomic and not cause any fatigue, injury from bad positions, or distraction owing to discomfort.

The Ministry recommends consulting all the users of learning environments, including students and staff, as they understand very well what makes a good learning environment. Parents and other members of the community can also participate in the consultation. However, there is no information about how and when to involve the users, parents or other community members in the design process.

Although many teachers are comfortable working in traditional classroom designs and layouts, a survey carried out by AC Nelson for the Ministry revealed that teachers prefer spaces that enable teaching and learning using different methods and techniques. However, the current guidelines do not suggest what these different learning techniques might be or how the classroom space might be affected in supporting them. The Ministry recommends that schools refer to the guidelines for basic issues or to solve simple problems with a school building. However, for complex problems, the Ministry recommends consulting design professionals. In the designing and building process, the government asks the school to provide the architect with a brief based on a discussion between the school and its users. The brief should contain details about the function of the 
new building and standards for acoustics, air quality, heating, and lighting. However, no mention of the interior learning environment is made at this stage. All building work needs to follow the requirements of the New Zealand Building Code (NZBC), which covers a range of topics, including fire safety, moisture exclusion, heating, ventilation, lighting, plumbing and drainage, and access for people with special needs.

The guidelines include discussion of the physical requirements for designing quality learning environments, including function, size, proportions, finishes, colour, furniture, connection with other spaces and with outdoors, and flexibility. Each school needs to be assessed differently because one design solution may not be suitable for all conditions. However, there are a limited number of learning methods so it could be argued that some more specific measurements related to different types of learning could be given, apart from the idea of having flexibility.

In the interior design, function, and aesthetic section of the guidelines, the Ministry provides grouped information about internal layout, finishing materials, furniture, dimensions, and colours of classrooms, computer rooms, multi-purpose halls, gyms, libraries, music rooms, art rooms, material technology rooms, and food technology rooms. This information does not address the relationship between the different rooms in a school or even between different activities in one space. The guidelines only explain the materials, dimensions, and colours of each space separately. The only relationship discussed is that between furniture and user dimensions. The furniture mentioned in the 
guidelines for classrooms only includes desks, chairs, and storage units. There is a subsection about how to choose suitable desks and chairs that fit the sizes and ages of different students.

Guidelines for designing quality interior spaces for learning environments were removed from the Ministry website at the beginning of 2012, although guidelines for acoustics, heating, temperature and insulation, air quality, and lighting remain on the website to date (Ministry of Education, 2007).

\subsubsection{MODERn LEARning ENVIRONMENTS ACCORDing TO THE Ministry OF EDUCATION}

Teaching and learning has changed from the traditional method, where everyone learnt in the same place, at the same time, in the same way, and from the same person, to the modern way, where students are actively involved in decision making, collaborate with each other, and make connections within and across learning spaces (Ministry of Education, 2014c). Thus, guidelines and examples are needed for learning environments that support these changes. These new learning environments are called modern learning environments. The Ministry of Education has provided some guidelines for and examples of these to help users and architects with their design. However, there was an update of the Ministry of Education website in July 2014 and the page related to modern learning environments was altered.

The two sections below discuss the Ministry's examples and guidelines before and after the update. 


\subsubsection{EXAMPLES PROVIDED By THE MiNistRy} WEBSITE UNTIL JULY 2014.

These examples were provided on the Ministry of Education website prior to July 2014. No guidelines for designing modern learning environments were provided with the examples. All the information in this section is from the Ministry of Education (2012b).

The examples included new and remodelled schools, classrooms, multi-purpose halls, art spaces, health and sport spaces, science teaching spaces, and libraries. The examples explained the details of the design of the classrooms after the building process was completed. Because of the aim of this thesis, the focus here is only on primary school classroom examples, whether new or remodelled.

There were 22 examples of modern learning environments in primary school classrooms, representing a wide range of 1-10 decile ratings. The examples came from different cities and areas in New Zealand. The work completed in these examples was either building new classrooms, remodelling old ones, converting general classrooms to open plan classrooms, converting open plan classrooms to general classrooms, or relocating re-locatable classrooms. Almost all these examples presented ways in which the school cared about the internal environment treatment (acoustics, air quality, temperature, and lighting). Only four examples gave no information about the internal environment.

In terms of whether classroom users were involved in the design process or not, in 18 examples teachers were involved, 2 examples 
show that teachers were not involved and the last 2 examples give no information about teacher involvement in the design process. On the other hand, only 8 examples indicate students were involved in the design process, in 5 examples students were not involved, and in 9 examples there was no information about student involvement (Figure 4-2). Table 4-2 sets out how students were involved in the classroom design, while table 4-3 shows how teachers were involved in the design process.

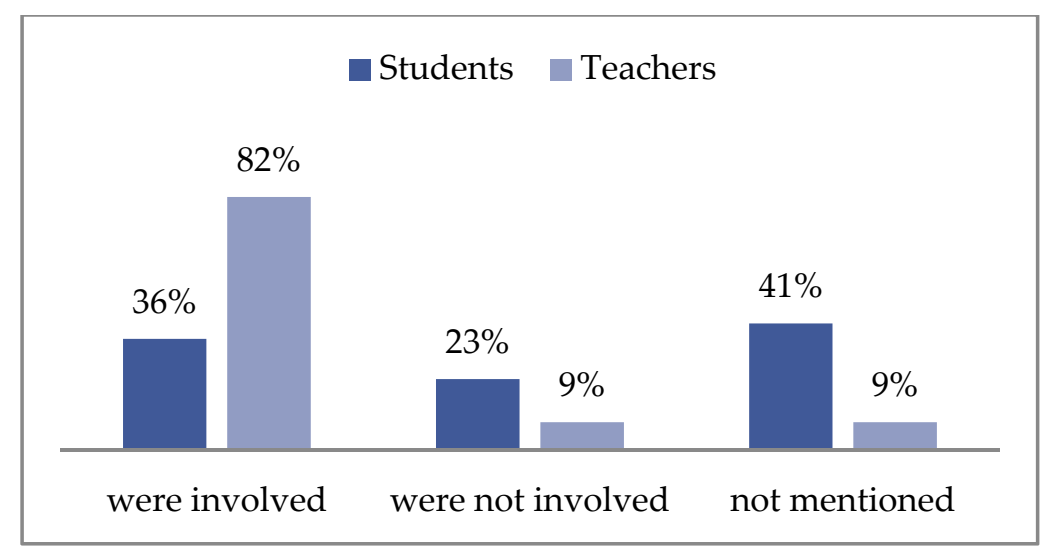

FIGURE 4-2: STUDENT AND TEACHER INVOLVEMENT IN CLASSROOM DESIGN.

TABle 4-2: Methods of StUdent inVOlVEMENT IN THE DESIGN PROCESS

\section{The school}

Eastern Hutt School

\section{How children were involved}

A survey was conducted with students about what they want and need in their classrooms. The results involved having good lighting, fresh air, soft carpets, spaces and rooms with good acoustics. 


\begin{tabular}{|c|c|}
\hline The school & How children were involved \\
\hline Koraunui School & $\begin{array}{l}\text { Students were not involved directly in design. Suggestions from } \\
\text { and recommendations of children were taken account of during the } \\
\text { planning process. }\end{array}$ \\
\hline Lake Brunner School & Proposed plans were presented and discussed with the students. \\
\hline $\begin{array}{l}\text { Mangere Central } \\
\text { School }\end{array}$ & Not mentioned \\
\hline Newfield Park School & $\begin{array}{l}\text { A random sample of students were interviewed and asked about } \\
\text { how their learning environment could be improved }\end{array}$ \\
\hline $\begin{array}{l}\text { Papakura Normal } \\
\text { School }\end{array}$ & $\begin{array}{l}\text { Senior students and the school leader (a student) had the } \\
\text { opportunity to discuss the ideas and plans. }\end{array}$ \\
\hline Parnell School & $\begin{array}{l}\text { Students were consulted during the early and mid-stages in the } \\
\text { plan development }\end{array}$ \\
\hline $\begin{array}{l}\text { Rangiora Borough } \\
\text { School }\end{array}$ & $\begin{array}{l}\text { Teachers discussed the preliminary ideas with their students and } \\
\text { involved them in the planning process. }\end{array}$ \\
\hline
\end{tabular}

\section{TABLE 4-3: Methods OF TEACHER INVOLVEMENT IN THE DESIGN}

PROCESS

\begin{tabular}{|c|c|}
\hline The school & How teachers were involved \\
\hline Bluestone School & $\begin{array}{l}\text { All met with architects to share pedagogy and passion for what } \\
\text { needed to be considered and achieved. They decided the colour } \\
\text { scheme together. }\end{array}$ \\
\hline
\end{tabular}




\begin{tabular}{|c|c|}
\hline The school & How teachers were involved \\
\hline Eastern Hutt School & $\begin{array}{l}\text { Consultation began at the earliest concept stages and, with } \\
\text { teachers, continued through the plan iterations. }\end{array}$ \\
\hline East Taieri School & Not mentioned \\
\hline Favona School & Not mentioned \\
\hline Fernworth School & Not mentioned \\
\hline Koraunui School & $\begin{array}{l}\text { There were workshops with staff and several community meetings } \\
\text { (open to all) over a nine-month period, to decide on the general } \\
\text { themes of the developments. There were staff/board of trustees } \\
\text { workshops as well. }\end{array}$ \\
\hline Lake Brunner School & $\begin{array}{l}\text { The staff were involved in the selection of colours for the new } \\
\text { library and classroom. }\end{array}$ \\
\hline $\begin{array}{l}\text { Mangere Central } \\
\text { School }\end{array}$ & Staff were kept informed and involved the whole way through \\
\hline $\begin{array}{l}\text { Newfield Park } \\
\text { School }\end{array}$ & Not mentioned \\
\hline $\begin{array}{l}\text { Papakura Normal } \\
\text { School }\end{array}$ & $\begin{array}{l}\text { Several meetings were held between the staff and the architect; } \\
\text { plans were displayed for comment; teachers' ideas were taken on } \\
\text { board. }\end{array}$ \\
\hline $\begin{array}{l}\text { Papatoetoe Central } \\
\text { School }\end{array}$ & Not mentioned \\
\hline
\end{tabular}




\begin{tabular}{|c|c|}
\hline The school & How teachers were involved \\
\hline $\begin{array}{l}\text { Papatoetoe South } \\
\text { School }\end{array}$ & Not mentioned \\
\hline Parnell School & $\begin{array}{l}\text { The whole staff was asked for their ideas over several months and } \\
\text { the ideas were presented to the designer. }\end{array}$ \\
\hline Pillans Point School & Not mentioned \\
\hline $\begin{array}{l}\text { Rangiora Borough } \\
\text { School }\end{array}$ & $\begin{array}{l}\text { There were ongoing meetings before, during and after the planning } \\
\text { and design stages. Meetings were held involving teachers, the } \\
\text { architect, the builder and the colour consultant. Changes were } \\
\text { agreed upon as a result of these meetings. }\end{array}$ \\
\hline $\begin{array}{l}\text { Richmond View } \\
\text { School }\end{array}$ & $\begin{array}{l}\text { The plan and colour scheme were drawn up by the principal and } \\
\text { the staff. }\end{array}$ \\
\hline Riwaka School & $\begin{array}{l}\text { The principal had consultation sessions with the staff in the } \\
\text { positioning, design and tendering of the projects. }\end{array}$ \\
\hline Whakarongo School & Not mentioned \\
\hline
\end{tabular}

The majority of classrooms are general classrooms (14 general classrooms from 22 examples). Of these, 4 examples have open floor plans and the rest are either various specialized rooms or a mixture of different types (general, open plan, and specialized rooms) (Figure 4-3). In the overall examples, 16 contain floor plans for the school and classrooms, while the other 6 do not provide or discuss the floor plan. Within the first 16 examples, none provide plans with full furniture layouts to show the classroom in use: 2 examples provide partially furnished plans, 
such as showing one group table in some rooms. The other 14 examples have no floor plans with furniture inside classrooms, although some show furniture in other settings, such as a reception counter in the Taieri School floor plan (Figure 4-4). Only a few pieces of furniture reflect the actual use of the classroom, as there are only the teacher's desk, a few desks in the centre of the room, and an art bench shown in each classroom. A label on the floor plan describes it as a multi-purpose room, which may indicate the intention that the room can be furnished with different layouts. The pictures provided in the examples show that the furnishing systems in the majority of classrooms in the selected schools depend mainly on desks, tables and chairs, whether in open plan or single cell spaces. However, in the open plan classroom examples, the photos show activity areas in addition to the use of group tables, moving away from the idea of individual desks. Figures 4-5 and 4-6 show the furniture in one open plan classroom layout and one single cell classroom. The Ministry did not comment on the furniture of open plan learning spaces in comparison with the furniture in single cell classrooms. They merely presented photos of different learning environments without any comments on what is best to follow or which one has problems to learn from.

School principals and staff had given feedback about the new or remodelled classrooms. The examples provided by the Ministry did not mention how this feedback was obtained. The feedback from the example schools and users of the classroom examples 
was mainly positive, as there were no negative comments about the new work completed for the classrooms in the examples.

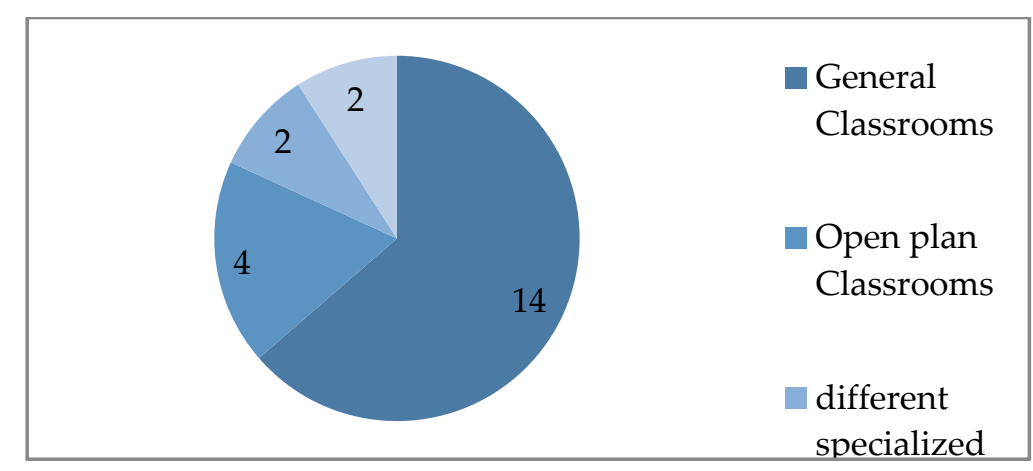

Figure 4-3: THE TYPes OF ClASSROOMS WITHIN THE 22 Ministry EXAMPLES.

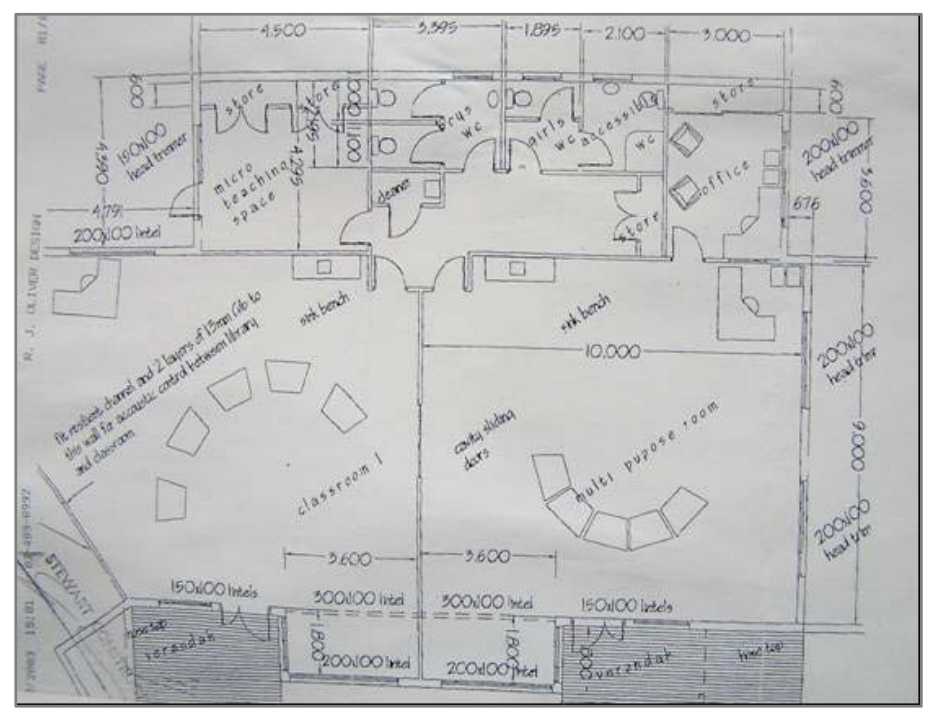

Figure 4-4: A PARTIALly FURNiSHED FloOR PlAN OF THE NEW ENTRANTS BLOCK AT EAST TAIERI SCHOOL 


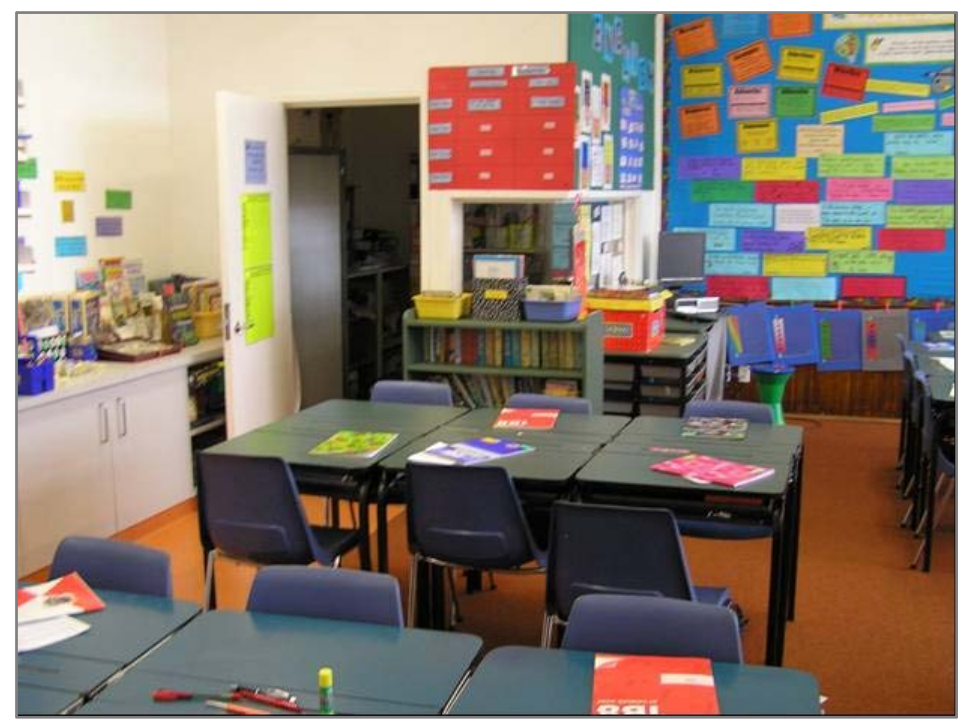

Figure 4-5: The furniture in a Single Cell Classroom, Parnell SCHOOL.

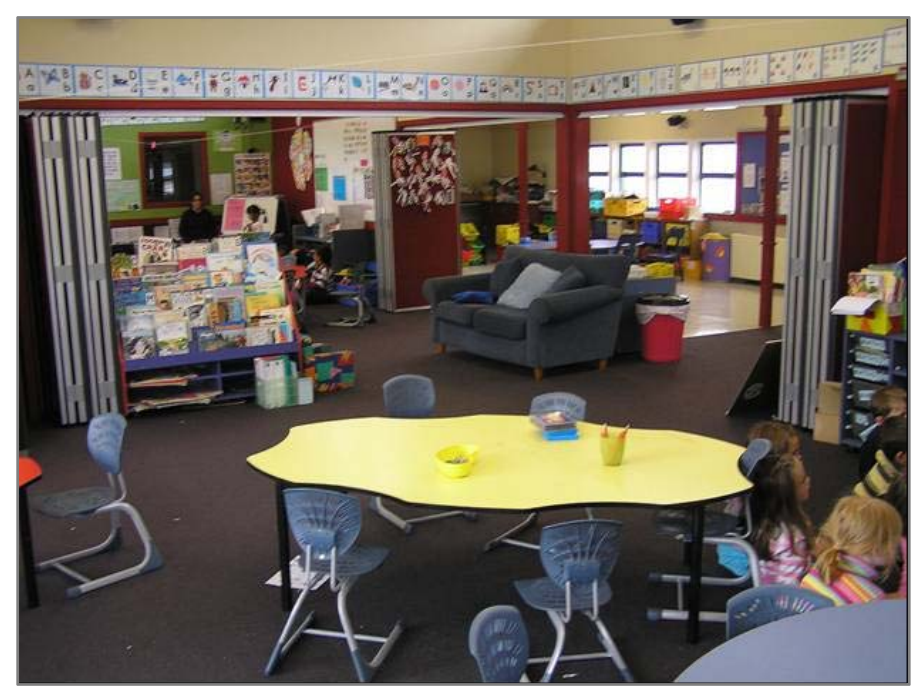

FIGURE 4-6: THE FURNITURE IN AN OPEN PLAN CLASSROOM, KORAUNUI SCHOOL.

Table 4-4 provides detailed information about the 22 examples, including the school name, location, decile rating, type of school, the type of building work completed, year of completing the construction work, environmental treatments, user participation 
in the design process, brief for the design, feedback after the construction work, floor plan availability, furniture layout availability, and type of classroom. 


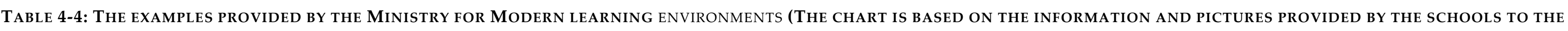
Ministry of Education. Schools Were not visited) (N/A= Not Applicable, NM= Not Mentioned).

\begin{tabular}{|c|c|c|c|c|c|c|c|c|c|c|c|c|c|c|}
\hline The school name & Location & Decile & Type & Type of work & $\begin{array}{c}\text { Year of } \\
\text { completion }\end{array}$ & $\begin{array}{c}\text { Environ- } \\
\text { mental } \\
\text { treat- } \\
\text { ment }\end{array}$ & $\begin{array}{c}\text { User } \\
\text { participation } \\
\text { : teachers }\end{array}$ & $\begin{array}{l}\text { User } \\
\text { partici- } \\
\text { pation: } \\
\text { students }\end{array}$ & $\begin{array}{c}\text { Briefing } \\
\text { the } \\
\text { designer/ } \\
\text { builder }\end{array}$ & Feedback & $\begin{array}{l}\text { Floor } \\
\text { plans }\end{array}$ & $\begin{array}{l}\text { Furni- } \\
\text { ture } \\
\text { layout } \\
\text { plans }\end{array}$ & $\begin{array}{c}\text { Furnishing } \\
\text { system (some } \\
\text { information was } \\
\text { gained from the } \\
\text { pictures } \\
\text { provided in the } \\
\text { examples) } \\
\end{array}$ & $\begin{array}{l}\text { Type of } \\
\text { classroom }\end{array}$ \\
\hline Belmont School & $\begin{array}{l}\text { Lower } \\
\text { Hutt }\end{array}$ & 9 & $\begin{array}{c}\text { Contributing } \\
\text { primary }\end{array}$ & $\begin{array}{l}\text { Five re-locatable } \\
\text { classrooms }\end{array}$ & 2004 & Yes & NM & NM & NM & $\begin{array}{c}\text { The children } \\
\text { are } \\
\text { settled, } \\
\text { confident } \\
\text { and happy } \\
\end{array}$ & No & N/A & $\begin{array}{l}\text { From the } \\
\text { pictures: } \\
\text { desks and } \\
\text { chairs }\end{array}$ & $\begin{array}{c}\text { General } \\
\text { classrooms }\end{array}$ \\
\hline Bluestone School & Timaru & NM & Full primary & $\begin{array}{l}\text { Merged school with re- } \\
\text { sited } \\
\text { re-locatable } \\
\text { classrooms and new } \\
\text { buildings with new } \\
\text { classrooms }\end{array}$ & $2005 / 2006$ & Yes & Yes & NM & NM & $\begin{array}{c}\text { Children } \\
\text { value the } \\
\text { opportunitie } \\
\text { s of learning } \\
\text { in a bigger } \\
\text { group in a } \\
\text { bigger space. } \\
\text { Provides } \\
\text { best of open } \\
\text { plan and } \\
\text { single class } \\
\text { combined. }\end{array}$ & No & N/A & $\begin{array}{l}\text { From the } \\
\text { pictures: } \\
\text { desks and } \\
\text { chairs, soft } \\
\text { settings } \\
\text { (cushions) }\end{array}$ & $\begin{array}{l}\text { Different } \\
\text { specialized } \\
\text { rooms } \\
\text { (classrooms) } \\
\text { and inside } \\
\text { /outside } \\
\text { connection }\end{array}$ \\
\hline $\begin{array}{l}\text { Eastern Hutt } \\
\text { School }\end{array}$ & $\begin{array}{l}\text { Lower } \\
\text { Hutt }\end{array}$ & 10 & $\begin{array}{c}\text { Contributing } \\
\text { primary }\end{array}$ & $\begin{array}{l}\text { New block (open plan } \\
\text { learning space) with } \\
\text { two classrooms } \\
\text { separated by a smaller } \\
\text { computer suite }\end{array}$ & 1996 & Yes & Yes & Yes & Yes & $\begin{array}{l}\text { Not formal } \\
\text { (better than } \\
\text { before) }\end{array}$ & $\begin{array}{l}\text { just } \\
\text { block } \\
\text { layout }\end{array}$ & No & $\begin{array}{l}\text { Inquiry- } \\
\text { based, } \\
\text { multi-activity } \\
\text { approach } \\
\text { Pictures: } \\
\text { desks and } \\
\text { chairs. }\end{array}$ & $\begin{array}{l}\text { Open plan } \\
\text { (opening into } \\
\text { each other } \\
\text { through } \\
\text { folding } \\
\text { internal } \\
\text { walls) }\end{array}$ \\
\hline $\begin{array}{l}\text { East Taieri } \\
\text { School }\end{array}$ & Mosgiel & 9 & $\begin{array}{c}\text { Contributing } \\
\text { primary }\end{array}$ & $\begin{array}{c}\text { A new building: two } \\
\text { new } \\
\text { entrances to } \\
\text { classrooms }\end{array}$ & 2004 & Yes & Yes & NM & Yes & NM & Yes & Partial & $\begin{array}{l}\text { Different } \\
\text { activity zones } \\
\text { Pictures: } \\
\text { tables and } \\
\text { chairs }\end{array}$ & Open plan \\
\hline Elmgrove School & Mosgiel & $\mathrm{N} / \mathrm{M}$ & $\begin{array}{c}\text { Contributing } \\
\text { primary }\end{array}$ & $\begin{array}{c}\text { New buildings } \\
\text { including large } \\
\text { verandas } \\
\text { added to two of the } \\
\text { classroom blocks; plus } \\
\text { two new re-locatable } \\
\text { classrooms }\end{array}$ & 2005 & Yes & No & NM & Yes & NM & Yes & Partial & NM & $\begin{array}{c}\text { General } \\
\text { classrooms } \\
\text { and covered } \\
\text { outdoor } \\
\text { teaching and } \\
\text { learning }\end{array}$ \\
\hline
\end{tabular}




\begin{tabular}{|c|c|c|c|c|c|c|c|c|c|c|c|c|c|c|}
\hline The school name & Location & Decile & Type & Type of work & $\begin{array}{c}\text { Year of } \\
\text { completion }\end{array}$ & $\begin{array}{c}\text { Environ- } \\
\text { mental } \\
\text { treat- } \\
\text { ment }\end{array}$ & $\begin{array}{c}\text { User } \\
\text { participation } \\
\text { : teachers }\end{array}$ & $\begin{array}{l}\text { User } \\
\text { partici- } \\
\text { pation: } \\
\text { students }\end{array}$ & $\begin{array}{l}\text { Briefing } \\
\text { the } \\
\text { designer/ } \\
\text { builder }\end{array}$ & Feedback & $\begin{array}{l}\text { Floor } \\
\text { plans }\end{array}$ & $\begin{array}{l}\text { Furni- } \\
\text { ture } \\
\text { layout } \\
\text { plans }\end{array}$ & $\begin{array}{c}\text { Furnishing } \\
\text { system (some } \\
\text { information was } \\
\text { gained from the } \\
\text { pictures } \\
\text { provided in the } \\
\text { examples) } \\
\end{array}$ & $\begin{array}{c}\text { Type of } \\
\text { classroom }\end{array}$ \\
\hline & & & & & & & & & & & & & & $\begin{array}{c}\text { veranda } \\
\text { spaces }\end{array}$ \\
\hline Favona School & $\begin{array}{c}\text { Manukau } \\
\text { City }\end{array}$ & 1 & $\begin{array}{c}\text { Contributing } \\
\text { primary }\end{array}$ & $\begin{array}{l}\text { Converted open plan } \\
\text { teaching spaces } \\
\text { into single-cell } \\
\text { classrooms }\end{array}$ & 2001 & NM & Yes & NM & NM & $\begin{array}{c}\text { Larger and } \\
\text { quieter } \\
\text { environment } \\
s\end{array}$ & No & NA & $\begin{array}{l}\text { Tables and } \\
\text { chairs, } \\
\text { computer } \\
\text { areas, relaxed } \\
\text { reading and } \\
\text { discussion } \\
\text { areas, mat, } \\
\text { wet areas, } \\
\text { library } \\
\text { corners, and } \\
\text { shelving bays }\end{array}$ & $\begin{array}{c}\text { General } \\
\text { classrooms }\end{array}$ \\
\hline $\begin{array}{l}\text { Fernworth } \\
\text { School }\end{array}$ & $\begin{array}{c}\text { Invercargi } \\
\|\end{array}$ & 2 & $\begin{array}{c}\text { Contributing } \\
\text { primary }\end{array}$ & $\begin{array}{l}\text { Four new classrooms } \\
\text { and remodelling } \\
\text { and re-siting of two } \\
\text { existing re-locatable } \\
\text { classrooms }\end{array}$ & 2005 & Yes & Yes & No & No & $\begin{array}{c}\text { Many } \\
\text { different } \\
\text { teaching and } \\
\text { learning } \\
\text { opportunitie } \\
\text { s are being } \\
\text { picked up }\end{array}$ & Yes & No & $\begin{array}{l}\text { From the } \\
\text { pictures: } \\
\text { desks and } \\
\text { chairs }\end{array}$ & $\begin{array}{l}\text { General } \\
\text { classrooms } \\
\text { with } \\
\text { indoor/outdo } \\
\text { or flow }\end{array}$ \\
\hline Koraunui School & $\begin{array}{l}\text { Stokes } \\
\text { Valley }\end{array}$ & NM & Contributing school & $\begin{array}{l}\text { Classrooms } \\
\text { (New and } \\
\text { Remodelled) }\end{array}$ & 2007 & Yes & Yes & Yes & No & $\begin{array}{l}\text { All teachers } \\
\text { were } \\
\text { pleased with } \\
\text { the way the } \\
\text { campus was } \\
\text { working, and } \\
\text { especially } \\
\text { with the new } \\
\text { rooms }\end{array}$ & Yes & No & $\begin{array}{l}\text { From the } \\
\text { pictures: } \\
\text { tables, } \\
\text { desks and } \\
\text { some other } \\
\text { settings such } \\
\text { as a sofa }\end{array}$ & $\begin{array}{l}\text { Open-plan } \\
\text { flexible } \\
\text { spaces of } \\
\text { varying area }\end{array}$ \\
\hline $\begin{array}{l}\text { Lake Brunner } \\
\text { School }\end{array}$ & $\begin{array}{l}\text { West } \\
\text { Coast }\end{array}$ & 6 & Full primary & New classroom & 2005 & Yes & Yes & Yes & $\begin{array}{l}\text { No/ just a } \\
\text { plan }\end{array}$ & $\begin{array}{l}\text { They are } \\
\text { very happy } \\
\text { with its } \\
\text { benefits and } \\
\text { features }\end{array}$ & Yes & No & $\begin{array}{l}\text { From the } \\
\text { pictures: } \\
\text { desks } \\
\text { and chairs }\end{array}$ & $\begin{array}{l}\text { General } \\
\text { classrooms } \\
\text { with } \\
\text { indoor/outdo } \\
\text { or flow }\end{array}$ \\
\hline
\end{tabular}




\begin{tabular}{|c|c|c|c|c|c|c|c|c|c|c|c|c|c|c|}
\hline The school name & Location & Decile & Type & Type of work & $\begin{array}{c}\text { Year of } \\
\text { completion }\end{array}$ & $\begin{array}{c}\text { Environ- } \\
\text { mental } \\
\text { treat- } \\
\text { ment }\end{array}$ & $\begin{array}{c}\text { User } \\
\text { participation } \\
\text { : teachers }\end{array}$ & $\begin{array}{c}\text { User } \\
\text { partici- } \\
\text { pation: } \\
\text { students }\end{array}$ & $\begin{array}{l}\text { Briefing } \\
\text { the } \\
\text { designer/ } \\
\text { builder }\end{array}$ & Feedback & $\begin{array}{l}\text { Floor } \\
\text { plans }\end{array}$ & $\begin{array}{l}\text { Furni- } \\
\text { ture } \\
\text { layout } \\
\text { plans }\end{array}$ & $\begin{array}{c}\text { Furnishing } \\
\text { system (some } \\
\text { information was } \\
\text { gained from the } \\
\text { pictures } \\
\text { provided in the } \\
\text { examples) } \\
\end{array}$ & $\begin{array}{c}\text { Type of } \\
\text { classroom }\end{array}$ \\
\hline $\begin{array}{l}\text { Mangere Central } \\
\text { School }\end{array}$ & $\begin{array}{l}\text { Manukau } \\
\text { City }\end{array}$ & NM & Full primary & $\begin{array}{c}\text { Classrooms } \\
\text { (new and remodelled) }\end{array}$ & 2003-2006 & Yes & Yes & Yes & No & $\begin{array}{c}\text { Staff, } \\
\text { community } \\
\text { and visitors } \\
\text { have been all } \\
\text { positive }\end{array}$ & No & NA & $\begin{array}{l}\text { From the } \\
\text { pictures: } \\
\text { desks } \\
\text { and chairs }\end{array}$ & $\begin{array}{c}\text { Includes } \\
\text { general } \\
\text { classrooms, } \\
\text { open plan } \\
\text { spaces, } \\
\text { flexible or } \\
\text { multi-size } \\
\text { spaces } \\
\end{array}$ \\
\hline $\begin{array}{l}\text { Nelson Park } \\
\text { School }\end{array}$ & Napier & NM & $\begin{array}{c}\text { Contributing } \\
\text { primary }\end{array}$ & $\begin{array}{l}\text { Classrooms } \\
\text { (remodelled) }\end{array}$ & 1998 & NM & NM & NM & NM & $\begin{array}{l}\text { The students } \\
\text { are more } \\
\text { relaxed and } \\
\text { happier in } \\
\text { the } \\
\text { classrooms } \\
\text { now } \\
\end{array}$ & No & NA & $\begin{array}{l}\text { From the } \\
\text { pictures: } \\
\text { desks } \\
\text { and chairs }\end{array}$ & $\begin{array}{l}\text { General } \\
\text { classrooms } \\
\text { with } \\
\text { indoor/outdo } \\
\text { or flow }\end{array}$ \\
\hline $\begin{array}{l}\text { Newfield Park } \\
\text { School }\end{array}$ & NM & $2 \mathrm{E}$ & $\begin{array}{c}\text { Contributing } \\
\text { primary }\end{array}$ & $\begin{array}{l}\text { Classroom block has } \\
\text { been remodelled }\end{array}$ & 2009 & Yes & Yes & Yes & NM & $\begin{array}{c}\text { More } \\
\text { popular and } \\
\text { better used } \\
\text { than } \\
\text { anticipated }\end{array}$ & Yes & No & $\begin{array}{l}\text { From the } \\
\text { pictures: } \\
\text { desks } \\
\text { and chairs }\end{array}$ & $\begin{array}{l}\text { Flexible } \\
\text { rooms with } \\
\text { breakout } \\
\text { spaces with } \\
\text { indoor/outdo } \\
\text { or flow }\end{array}$ \\
\hline $\begin{array}{l}\text { Papakura Normal } \\
\text { School }\end{array}$ & NM & 3 & Full primary & $\begin{array}{c}\text { General classrooms } \\
\text { (New and } \\
\text { Remodelled) }\end{array}$ & 2006 & Yes & Yes & Yes & No & NM & Yes & No & $\begin{array}{l}\text { From the } \\
\text { pictures: } \\
\text { desks } \\
\text { and chairs }\end{array}$ & $\begin{array}{l}\text { General } \\
\text { classrooms }\end{array}$ \\
\hline $\begin{array}{l}\text { Papatoetoe } \\
\text { Central School }\end{array}$ & NM & NM & $\begin{array}{c}\text { Contributing } \\
\text { primary }\end{array}$ & $\begin{array}{l}\text { Three } 1970 \text { s style } \\
\text { open-plan classrooms } \\
\text { converted into single } \\
\text { classroom units; a new } \\
\text { two-storey classroom } \\
\text { block added }\end{array}$ & 2004 & NM & Yes & NM & NM & NM & No & NA & $\begin{array}{l}\text { From the } \\
\text { pictures: } \\
\text { desks } \\
\text { and chairs }\end{array}$ & $\begin{array}{l}\text { General } \\
\text { classrooms }\end{array}$ \\
\hline $\begin{array}{l}\text { Papatoetoe } \\
\text { South School }\end{array}$ & NM & NM & $\begin{array}{c}\text { Contributing } \\
\text { primary }\end{array}$ & $\begin{array}{c}\text { New buildings and } \\
\text { remodelling/conversio } \\
n\end{array}$ & 1997-2005 & Yes & Yes & No & Yes & 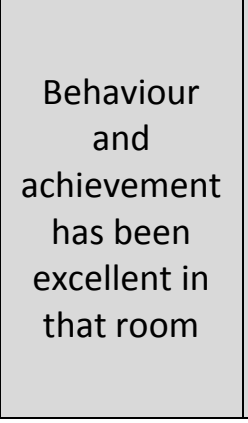 & Yes & No & $\begin{array}{l}\text { From the } \\
\text { pictures: } \\
\text { desks and } \\
\text { chairs and } \\
\text { specialized } \\
\text { corners }\end{array}$ & $\begin{array}{l}\text { Open plan } \\
\text { (general } \\
\text { classrooms } \\
\text { have been } \\
\text { inter-linked } \\
\text { with folding } \\
\text { walls for } \\
\text { flexible and } \\
\text { open plan) }\end{array}$ \\
\hline
\end{tabular}




\begin{tabular}{|c|c|c|c|c|c|c|c|c|c|c|c|c|c|c|}
\hline The school name & Location & Decile & Type & Type of work & $\begin{array}{c}\text { Year of } \\
\text { completion }\end{array}$ & $\begin{array}{c}\text { Environ- } \\
\text { mental } \\
\text { treat- } \\
\text { ment }\end{array}$ & $\begin{array}{c}\text { User } \\
\text { participation } \\
\text { : teachers }\end{array}$ & $\begin{array}{l}\text { User } \\
\text { partici- } \\
\text { pation: } \\
\text { students }\end{array}$ & $\begin{array}{l}\text { Briefing } \\
\text { the } \\
\text { designer/ } \\
\text { builder }\end{array}$ & Feedback & $\begin{array}{l}\text { Floor } \\
\text { plans }\end{array}$ & $\begin{array}{l}\text { Furni- } \\
\text { ture } \\
\text { layout } \\
\text { plans }\end{array}$ & $\begin{array}{l}\text { Furnishing } \\
\text { system (some } \\
\text { information was } \\
\text { gained from the } \\
\text { pictures } \\
\text { provided in the } \\
\text { examples) } \\
\end{array}$ & $\begin{array}{l}\text { Type of } \\
\text { classroom }\end{array}$ \\
\hline Parnell School & $\mathrm{N} / \mathrm{M}$ & 10 & Full primary & $\begin{array}{l}\text { Remodelled general } \\
\text { classrooms } \\
\text { and a new technology } \\
\text { room }\end{array}$ & 2007 & Yes & Yes & Yes & Yes & $\begin{array}{c}\text { Positive } \\
\text { feedback } \\
\text { from } \\
\text { teachers, } \\
\text { students and } \\
\text { parents } \\
\end{array}$ & Yes & No & $\begin{array}{l}\text { From the } \\
\text { pictures: } \\
\text { desks } \\
\text { and chairs }\end{array}$ & $\begin{array}{l}\text { General } \\
\text { classrooms }\end{array}$ \\
\hline $\begin{array}{l}\text { Pillans Point } \\
\text { School }\end{array}$ & Tauranga & 9 & $\begin{array}{c}\text { Contributing } \\
\text { Primary }\end{array}$ & $\begin{array}{l}\text { New classroom and } \\
\text { extensions } \\
\text { to five classrooms }\end{array}$ & $\begin{array}{l}1998 \text { and } \\
2004\end{array}$ & Yes & Yes & NM & Yes & $\begin{array}{l}\text { The new } \\
\text { classroom is } \\
\text { great - } \\
\text { warm, } \\
\text { sunny, } \\
\text { ventilated, } \\
\text { quiet, easy } \\
\text { to work in, } \\
\text { and great to } \\
\text { set up for } \\
\text { multiuse }\end{array}$ & Yes & No & $\begin{array}{l}\text { Desks and } \\
\text { tables, } \\
\text { computers, } \\
\text { sink and wet } \\
\text { area, a } \\
\text { teacher } \\
\text { resources } \\
\text { area, a room } \\
\text { for children's } \\
\text { learning } \\
\text { activities }\end{array}$ & $\begin{array}{l}\text { General } \\
\text { classrooms }\end{array}$ \\
\hline $\begin{array}{l}\text { Rangiora } \\
\text { Borough School }\end{array}$ & Rangiora & NM & Full primary & $\begin{array}{c}\text { General Classrooms - } \\
\text { New }\end{array}$ & 2007 & Yes & Yes & Yes & NM & $\begin{array}{c}\text { Systematic } \\
\text { and } \\
\text { on-going } \\
\text { evaluation } \\
\text { throughout } \\
\text { the first few } \\
\text { months / } \\
\text { very positive } \\
\end{array}$ & Yes & No & $\begin{array}{l}\text { From the } \\
\text { pictures: } \\
\text { desks and } \\
\text { tables }\end{array}$ & $\begin{array}{l}\text { General } \\
\text { classrooms } \\
\text { with } \\
\text { indoor/outdo } \\
\text { or flow }\end{array}$ \\
\hline $\begin{array}{l}\text { Richmond View } \\
\text { School }\end{array}$ & Blenheim & NM & Full primary & $\begin{array}{l}\text { A new two-room } \\
\text { teaching block }\end{array}$ & 2003 & NM & Yes & NM & NM & Positive & Yes & No & $\begin{array}{l}\text { Private study } \\
\text { space and } \\
\text { open space } \\
\text { for whole } \\
\text { class and } \\
\text { group work }\end{array}$ & $\begin{array}{c}\text { General } \\
\text { classrooms } \\
\text { with fixed } \\
\text { desks plus } \\
\text { open plan } \\
\text { areas for } \\
\text { class and } \\
\text { group } \\
\text { activities }\end{array}$ \\
\hline $\begin{array}{l}\text { Rosebank } \\
\text { Primary School }\end{array}$ & Balclutha & NM & Full primary & $\begin{array}{l}\text { Remodelling } \\
\text { classrooms }\end{array}$ & 2002 & Yes & No & No & No & NM & Yes & No & $\begin{array}{l}\text { From the } \\
\text { pictures: } \\
\text { desks and } \\
\text { tables }\end{array}$ & $\begin{array}{l}\text { General } \\
\text { classrooms } \\
\text { and flexible } \\
\text { group } \\
\text { teaching } \\
\text { space }\end{array}$ \\
\hline
\end{tabular}




\begin{tabular}{|c|c|c|c|c|c|c|c|c|c|c|c|c|c|c|}
\hline The school name & Location & Decile & Type & Type of work & $\begin{array}{c}\text { Year of } \\
\text { completion }\end{array}$ & $\begin{array}{c}\text { Environ- } \\
\text { mental } \\
\text { treat- } \\
\text { ment }\end{array}$ & $\begin{array}{c}\text { User } \\
\text { participation } \\
\text { : teachers }\end{array}$ & $\begin{array}{l}\text { User } \\
\text { partici- } \\
\text { pation: } \\
\text { students }\end{array}$ & $\begin{array}{l}\text { Briefing } \\
\text { the } \\
\text { designer/ } \\
\text { builder }\end{array}$ & Feedback & $\begin{array}{l}\text { Floor } \\
\text { plans }\end{array}$ & $\begin{array}{l}\text { Furni- } \\
\text { ture } \\
\text { layout } \\
\text { plans }\end{array}$ & $\begin{array}{c}\text { Furnishing } \\
\text { system (some } \\
\text { information was } \\
\text { gained from the } \\
\text { pictures } \\
\text { provided in the } \\
\text { examples) } \\
\end{array}$ & $\begin{array}{c}\text { Type of } \\
\text { classroom }\end{array}$ \\
\hline Riwaka School & Nelson & NM & Full primary & New buildings & 2006 & Yes & Yes & No & Yes & $\begin{array}{l}\text { Teachers } \\
\text { and } \\
\text { pupils love } \\
\text { the new } \\
\text { spaces }\end{array}$ & Yes & No & $\begin{array}{c}\text { One with } \\
\text { specialist } \\
\text { furniture and } \\
\text { fittings for art } \\
\text { and science } \\
\text { /from } \\
\text { pictures: } \\
\text { desks and } \\
\text { tables }\end{array}$ & $\begin{array}{c}\text { General } \\
\text { classrooms }\end{array}$ \\
\hline $\begin{array}{l}\text { Whakarongo } \\
\text { School }\end{array}$ & $\begin{array}{l}\text { Palmerst } \\
\text { one } \\
\text { North }\end{array}$ & 9 & Full primary & $\begin{array}{l}\text { New general } \\
\text { classrooms }\end{array}$ & 2007 & Yes & Yes & No & Yes & $\begin{array}{c}\text { Will be } \\
\text { evaluated in } \\
2008\end{array}$ & Yes & No & $\begin{array}{l}\text { Flexible } \\
\text { general } \\
\text { classrooms }\end{array}$ & $\begin{array}{c}\text { Flexible } \\
\text { general } \\
\text { classrooms }\end{array}$ \\
\hline
\end{tabular}




\subsubsection{RECENT MINISTRY UPDATES FOR MODERN LEARNING ENVIRONMENTS GUIDELINES}

In July 2014, the Ministry of Education updated the modern learning environments web page with new information and guidelines for those concerned with school building and school refurbishment.

The Ministry now defines a modern learning environment as one that is capable of being developed and adjusted as educational practices change and moderate. The modern learning environment mainly refers to the school classroom but may include other spaces in the school such as science laboratories and libraries (Ministry of Education, 2014c). Case studies of schools that have been changed to provide such modern learning environments are also given.

The Ministry suggests considering 8 critical elements when designing modern learning environments: accessibility, air quality, health and safety, heating, lighting, insulation, sustainability, and acoustics. For each element, the Ministry provides a gallery of photos and guidelines for ways to achieve the best implementation of these elements. For example, for air quality, the suggestion is to have adequate natural ventilation through windows at low/ high levels or artificial ventilation. Figures 4-7 and 4-8 provide examples of designing for good air quality. 


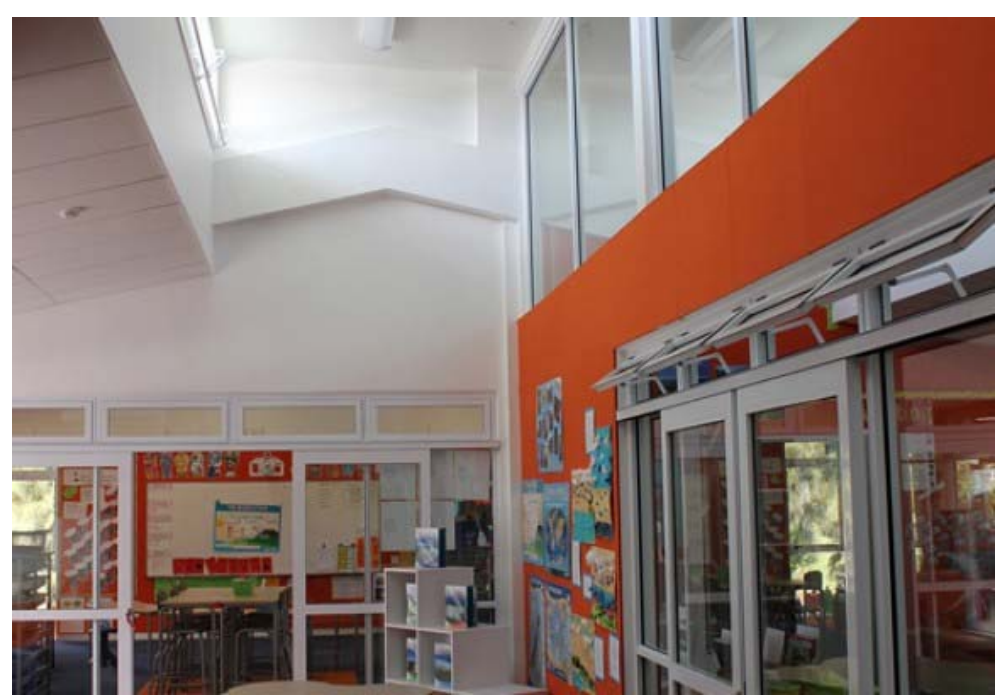

Figure 4-7: A Ministry EXAMPLE OF GOOD NATURAL VENTILATION THROUGH HIGH LEVEL WINDOWS.

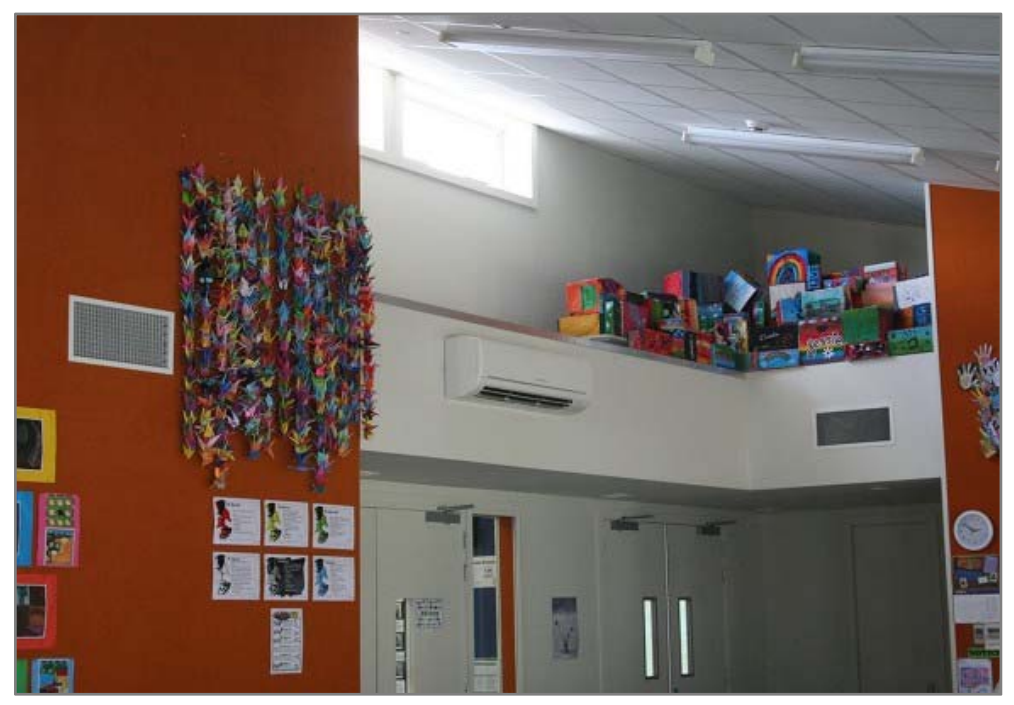

Figure 4-8: A Ministry EXAMPLE OF GOOD VENTILATION IN LEARNING ENVIRONMENTS THROUGH THE VENTILATION GRILLES IN THE WALLS.

The Ministry also provides general guidelines about creating good modern learning environments, as summarised below: 
- Open up corridors to the classrooms in old schools by using transparent dividers to allow co-operative teaching practices to occur.

- Remove some internal walls in order to enlarge spaces visually and physically.

- Create breakout areas throughout the school, both indoor and outdoor.

- Create areas for individuals, small groups and large community learning and teaching (Figures 4-9, 4-10)

- Provide different types of furniture for learning environments, such as modular seats, tables, couches, and chairs (Figures 4-11, 4-12, 4-13).

- Provide technology everywhere, including having wireless connections, TV mobile unit, computer labs, and interactive whiteboards (Figures 4-14, 4-15).

- Provide Specialist Activities areas in the school such as Science labs, Food Technology labs, Materials Technology labs, Performance areas, Auditoria stages, and PE and Health areas.

- Provide proper storage areas for students, such as personal lockers, cubbyholes, and scooter stands (Figures 4-16, 4-17).

- Provide appropriate areas for teachers that are within the learning areas

- Create buildings that have connections with the local community

(Ministry of Education, 2014c). 


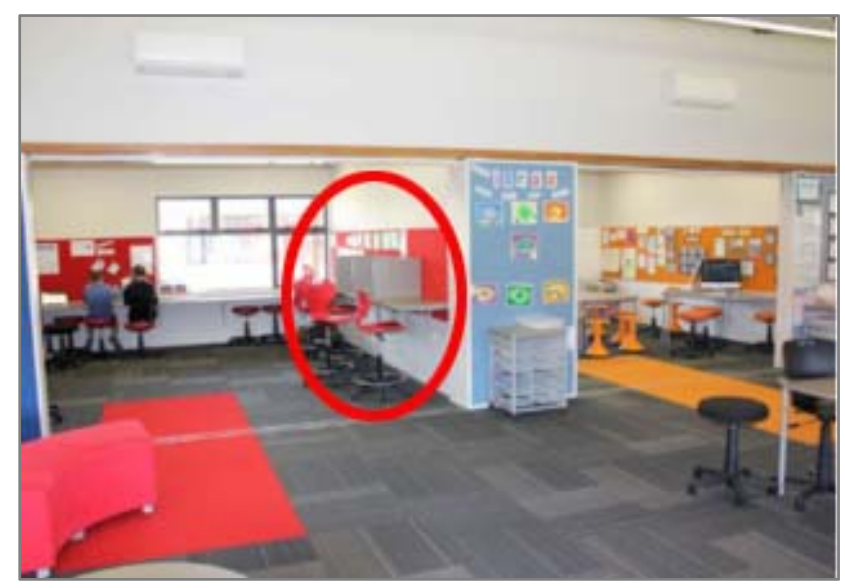

FIGURE 4-9: INDIVIDUAL SETTINGS IN A MODERN LEARNING ENVIRONMENT: THE INDIVIDUAL NOOK WITH CHAIRS.

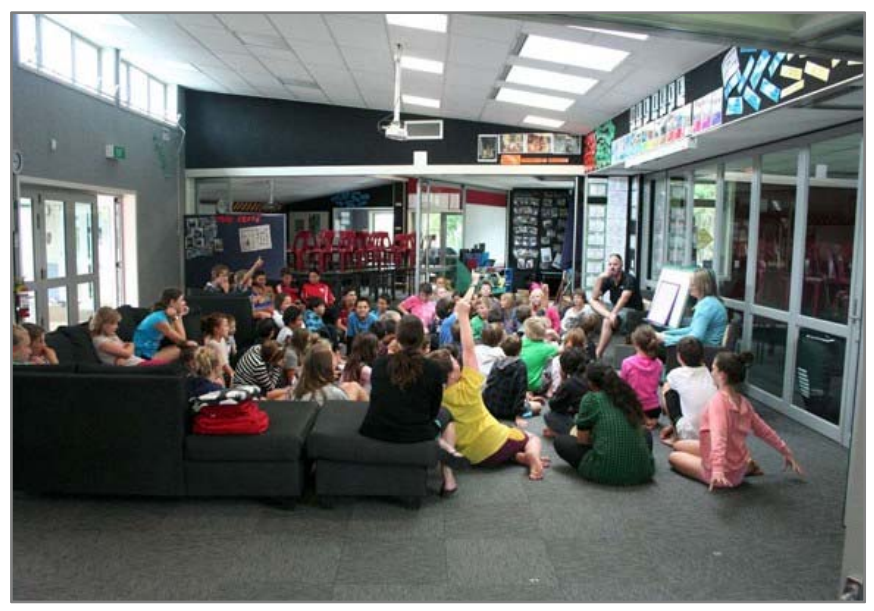

FIgURE 4-10: SETTING FOR A LARGE COMMUNITY GATHERING IN A MODERN LEARNING ENVIRONMENT. 


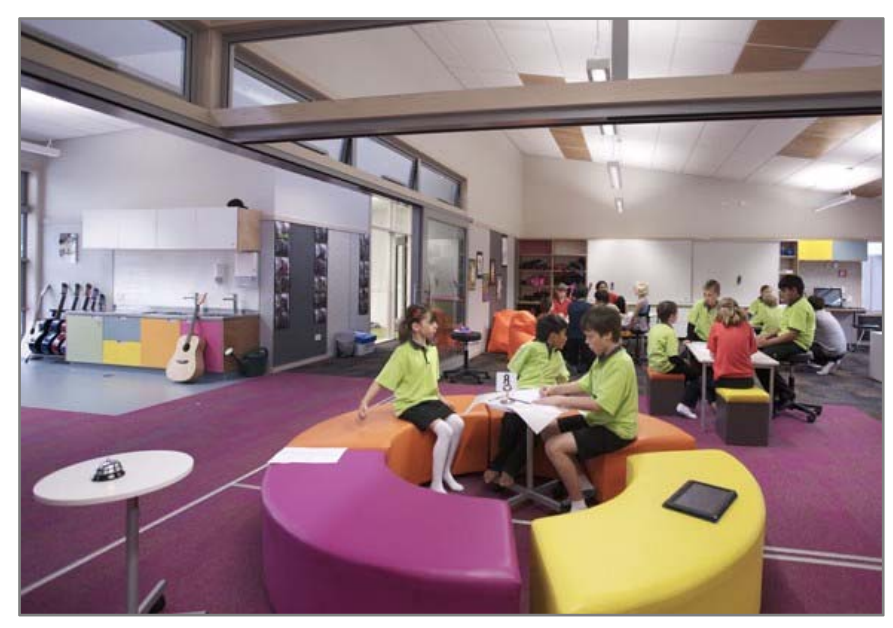

FIGURE 4-11: MODULAR SEATS IN A MODERN LEARNING ENVIRONMENT.

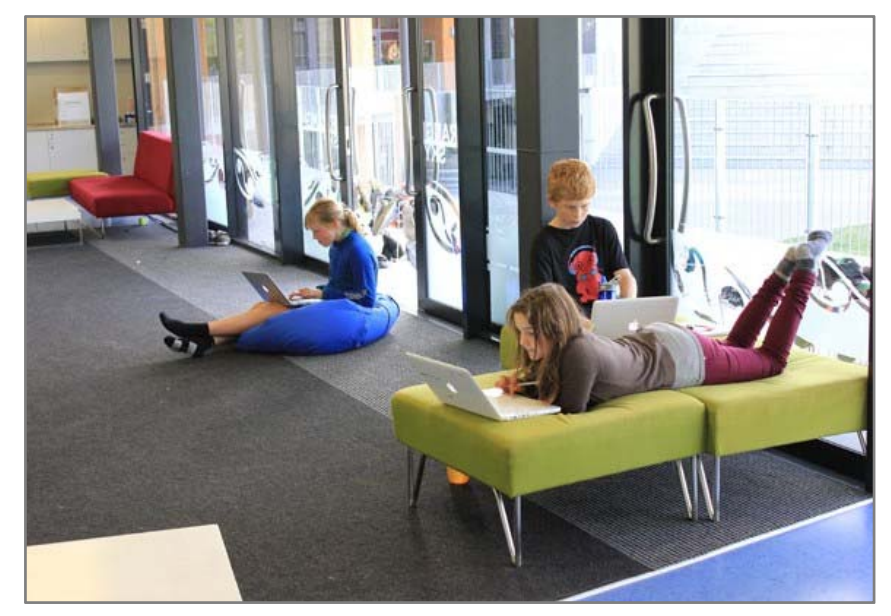

FIGURE 4-12: COUCHES IN A MODERN LEARNING ENVIRONMENT. 


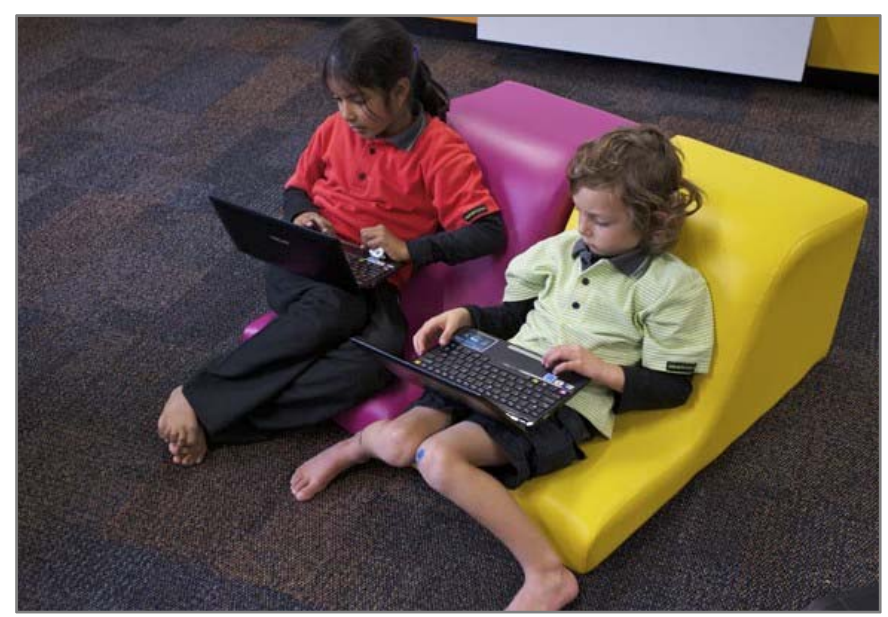

FIGURE 4-13: CHAIRS AND COMPUTERS IN A MODERN LEARNING ENVIRONMENT

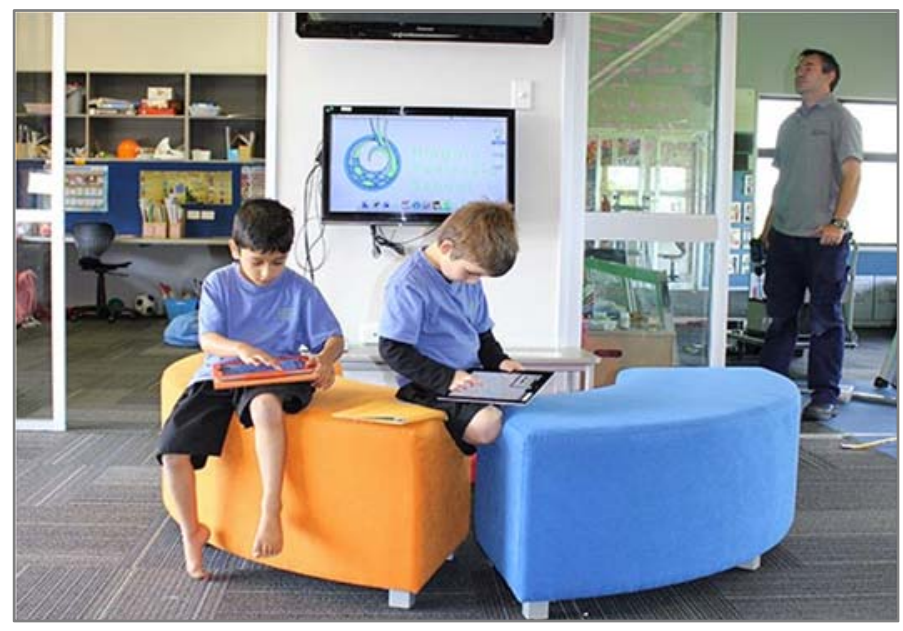

FIgURE 4-14: COMPUTER USE AROUND A MODERN LEARNING ENVIRONMENT THROUGH THE WI-FI CONNECTION. 


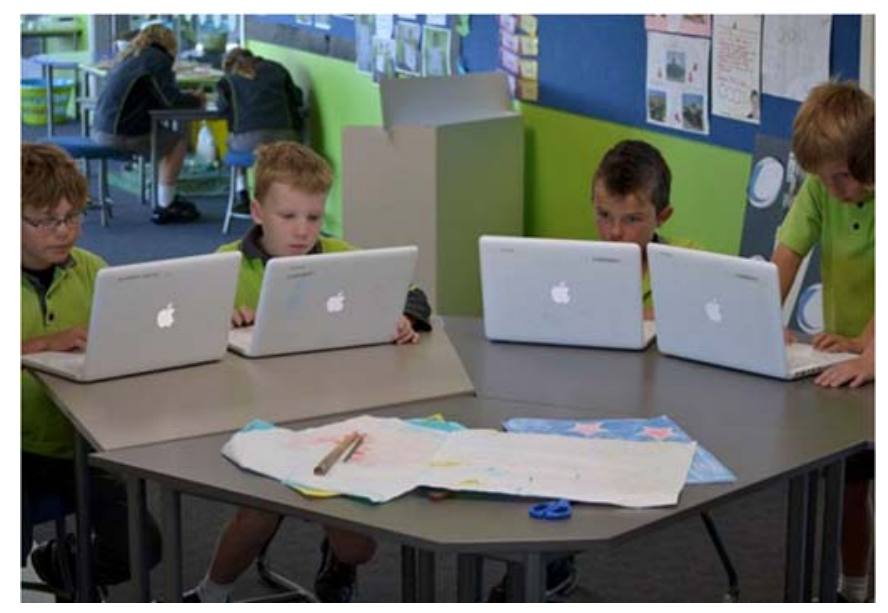

FIGURE 4-15: COMPUTER LABS IN A MODERN LEARNING ENVIRONMENT SUPPORTED BY A NUMBER OF LAPTOPS.

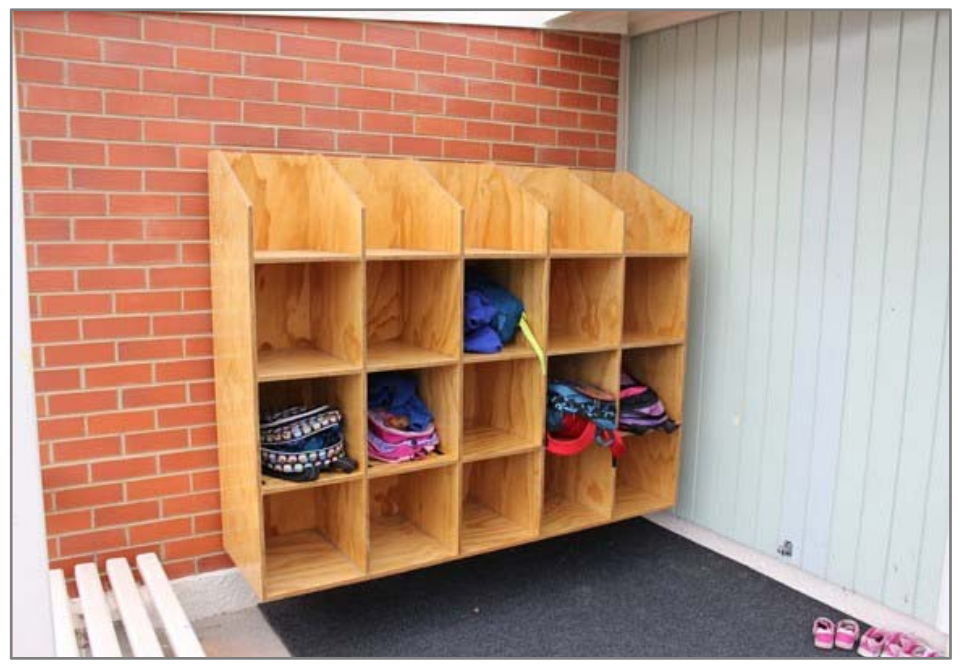

Figure 4-16: CUBbyHOLES AS STORAGE UNITS IN A MODERN LEARNING ENVIRONMENT 


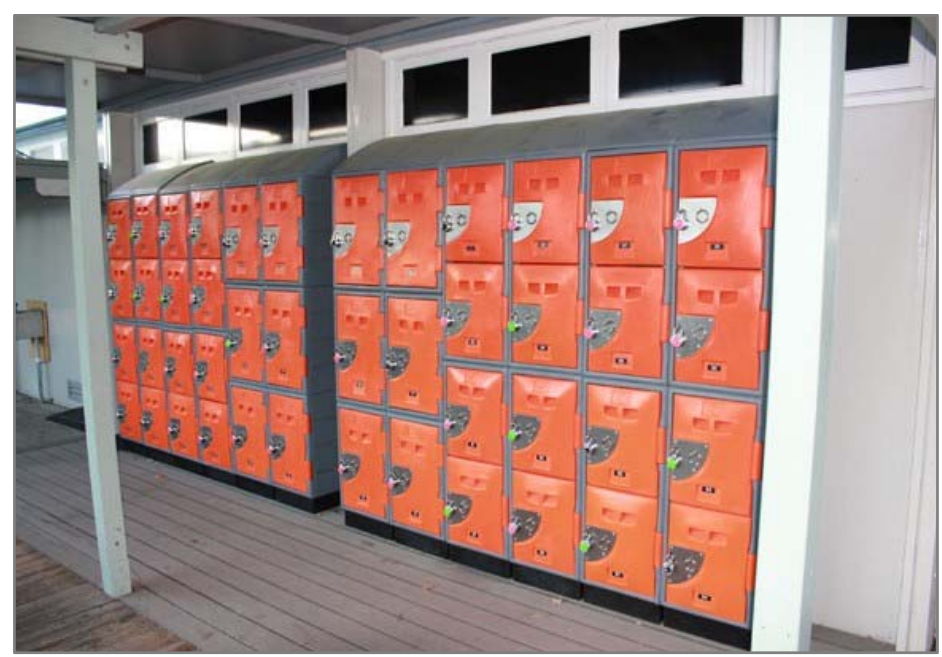

Figure 4-17: Personal lockers in a MOdern LeARNiNG ENVIRONMENT

The guidelines provided are mainly in the form of photos. There are insufficient details on how to achieve the guidelines. For example, some furniture layouts would be helpful in showing how the chairs and laptop computers fit in with the rest of the classroom furniture, or how the group setting could be rearranged for private study in the same space. The images are attractive but it is not clear how they fit with the other activities that normally take place in a primary school classroom (Ministry of Education, 2014c).

\subsubsection{CASE STUDIES OF MODERN LEARNING} ENVIRONMENTS

The Ministry provides cases studies of modern learning environments and how schools with these changed from a traditional style of classrooms to the modern environments. The case studies involve three New Zealand schools: Auckland Normal Intermediate, Woolston School, and Breens Intermediate. 
Auckland Normal Intermediate is a decile 9 school that has 700 students in a mix of re-locatable and permanent buildings. The school has changed to modern learning environments to support the changes in their curriculum, which now uses new teaching styles and technologies. After consulting considerable local and international research about designing modern learning environments, the school decided on a student-focused approach, where students are responsible for the way they learn. The school has opened the existing cellular classrooms into one large, open and flexible learning area. Desks and chairs for students were removed and replaced with a selection of flexible furniture choices, such as beanbags and couches. After the changes the school claims students were more motivated and engaged in the learning process as a consequence of having a say on what is needed inside the school and how and where they work and learn. The specialist activity areas support the learning inside classrooms. Having flexible furniture makes it easy for students to change the classroom layout more often. Students can learn individually, in small groups, or in large groups, as they now have individual spaces and breakout spaces all over the school. Perhaps the most important result was that students did not want to go back to the old learning styles and environments (Figure 4-18) (Ministry of Education, 2014a). 


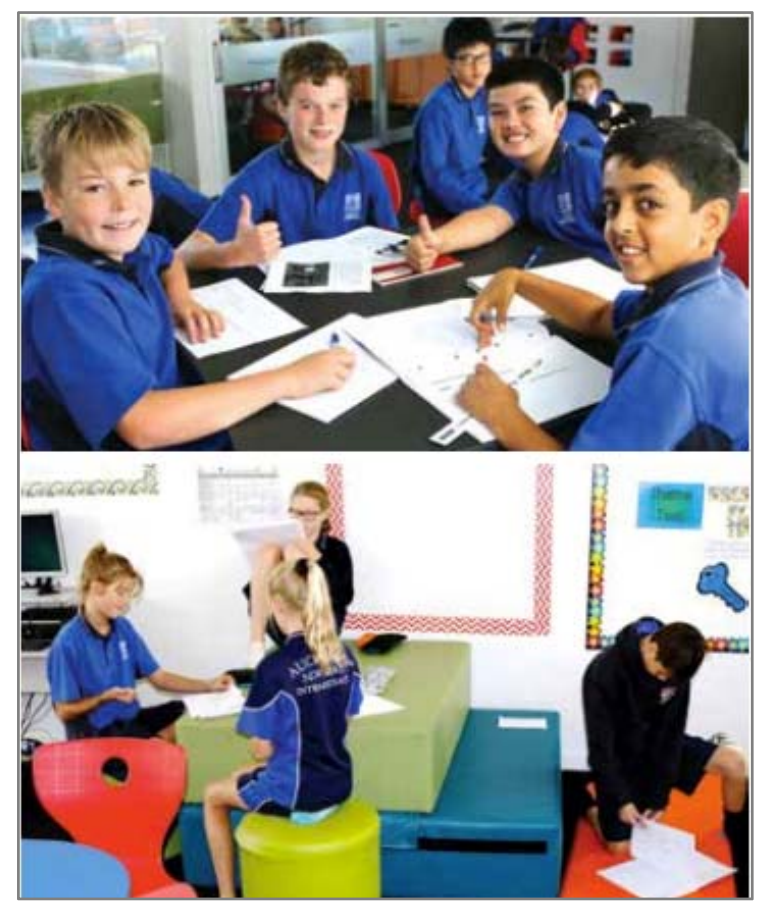

Figure 4-18: MODERn LEARNING ENVIRONMENTS IN AUCKLAND NORMAL INTERMEDIATE

The second school is Woolston School, which is a decile 2 full primary school with 330 students. The school consists of a mix of old and new buildings. The new buildings are good examples of modern learning environments using both open plan classrooms and learning studios. The old buildings consist of single cell classrooms, and teachers working in these wanted to improve their students' learning outcomes. They conducted some research and visited other schools and as a result decided to change the classrooms to more studentfocused learning areas. The design process involved a number of meetings with the staff to generate ideas. Teachers also discussed these ideas with their students. They also started to change their teaching styles in order to contribute to the change in the learning environments. The new project 
included a modern learning block. All the environments of the school, including open plan classrooms, learning studios, and the refurbished single cell classrooms, support a modern, flexible, open, and collaborative approach in teaching and learning. The single cell classrooms were changed to allow sharing of the teaching space, team teaching, a breakout area, creative use of furniture, and outdoor spaces for teaching and learning. Students use technology for learning, as they have 1:1 Google Chromebook devices that are connected to each other and to the teacher's in a form of collaborative learning. The furnishing style of the desks and chairs has changed in most areas to a new range of furniture that meets modern teaching and learning needs, such as group work tables and activity corners. After the project, students were more motivated and excited, especially with the fact they had helped in the design and selection of furniture (Figure 4-19) (Ministry of Education, 2014d).

The third school, Breens Intermediate, is a decile 6 intermediate school with 268 students. The school buildings consist of prefabricated re-locatable structures. The school was inspired by teaching philosophies that focus on sharing the teaching and learning responsibilities between teachers and students, and this led to the desire to change the existing learning environments to modern ones. First, they changed the school and teaching management to be more coaching and mentoring than instructing. The school removed some walls to open up spaces, and installed windows in other walls for 
more transparency between spaces. It also provided a range of furniture, such as beanbags, for the new modern learning environments. After the project, both students and teachers were more engaged and motivated. Teachers do not want to go back to the old learning styles and environments, and there has been an improvement in student learning outcomes (Figure 4-20) (Ministry of Education, 2014b).

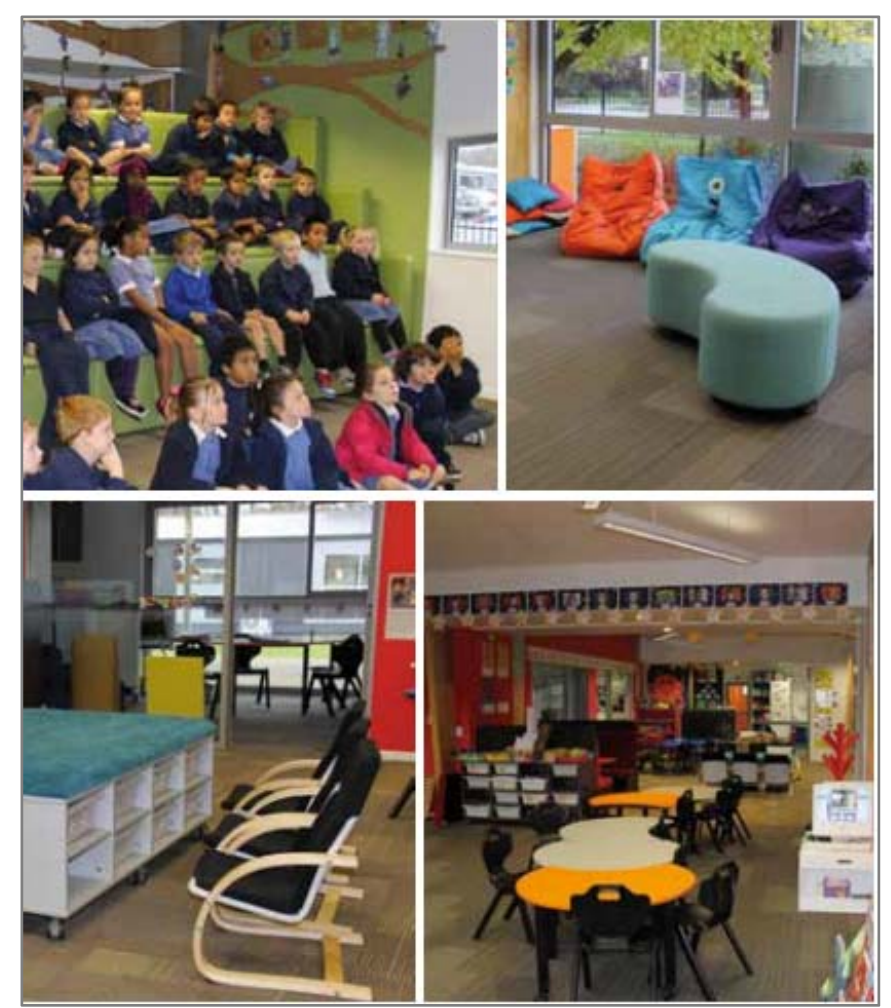

FIGURE 4-19: MODERN LEARNING ENVIRONMENTS IN WOOLSTON SCHOOL 


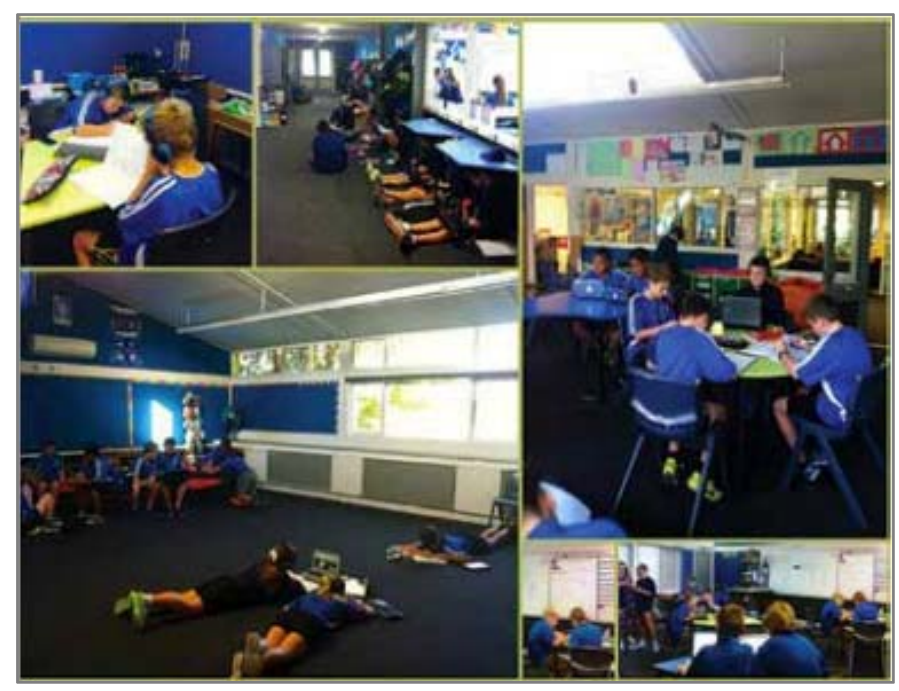

FIGURE 4-20: MODERN LEARNING ENVIRONMENTS IN BREENS INTERMEDIATE

\subsubsection{A MiNistry OF EDUCATION PILOT STUDY}

The 2012 Ministry pilot study involved the design and evaluation of learning studios and suites in a number of New Zealand schools. The Ministry also provided a brief for the learning studios, which essentially are small groups of classrooms around a shared learning area. For this research the two learning studios of the pilot project in the Wellington area were visited. These were the learning suites in Kilbirnie and Adventure schools.

The following sub-sections explain the brief behind this pilot project, reviews of the pilot projects completed by the five schools involved, and the researcher visits to and investigation of the two selected studios. 


\subsubsection{THE PILOT STUDY BRIEF:}

The pilot study of The Ministry of Education learning studios suggests designing for campfire, watering hole, and cave learning experiences. The campfire space accommodates traditional learning based on teacher directions. It can be a formal lecture-type arrangement or a storytelling arrangement. The second mode, the watering hole, is where peers and small groups of students can work and learn together. Last, the cave mode is where students can learn independently and individually. This can be achieved by having nooks and crannies in the layout.

The brief also talks about different settings and environmental aspects inside the learning studio, such as acoustics, electrical outlet positions, lighting, materials and finishing, and furniture. However, the discussion of furniture is very simple, as the brief only talks about the importance of providing group work settings in addition to individual settings.

The five pilot projects correspond to the guidelines in the brief, although in some examples the studios are similar, sometimes very similar, to the normal general classroom. The two visited schools were Kilbirnie School and Adventure School. The Kilbirnie School learning studios have a different furniture layout from normal general single cell classrooms, while Adventure School learning studios have a very similar furniture layout to that in general classrooms. 
This document, prepared by the Ministry and available for boards of trustees, provides guidelines for designing learning studio type classrooms in existing school campuses as part of the provision for roll growth. The aim of the document is to not to offer a standard design but to support schools.

The brief includes a guide for designing learning studios. This guide asserts that furniture should allow for different arrangements and layouts that enable students to learn via the three modes mentioned in connection with learning suites (campfire, watering hole, and cave). The guide suggests having a group of desks and tables in different sizes to suit different students. It also suggests having soft settings in some spaces, such as the shared learning area.

In the guide, a learning studio is defined as "a flexible classroom which will accommodate multiple activity centres" (Babbage Architects and Ministry of Education, 2012). It consists of open plan areas, breakout spaces, shared learning spaces, and outdoor-learning areas (Figure 4-21). Inside the studio, students should be able to learn in large groups or with the whole class, in small groups, and individually. Thus the learning studio should provide spaces for the three modes of learning (campfire, watering hole, cave). A learning suite consists of 2-4 learning studios with a shared learning area. All learning spaces and studios should have a visual connection with the shared area. 


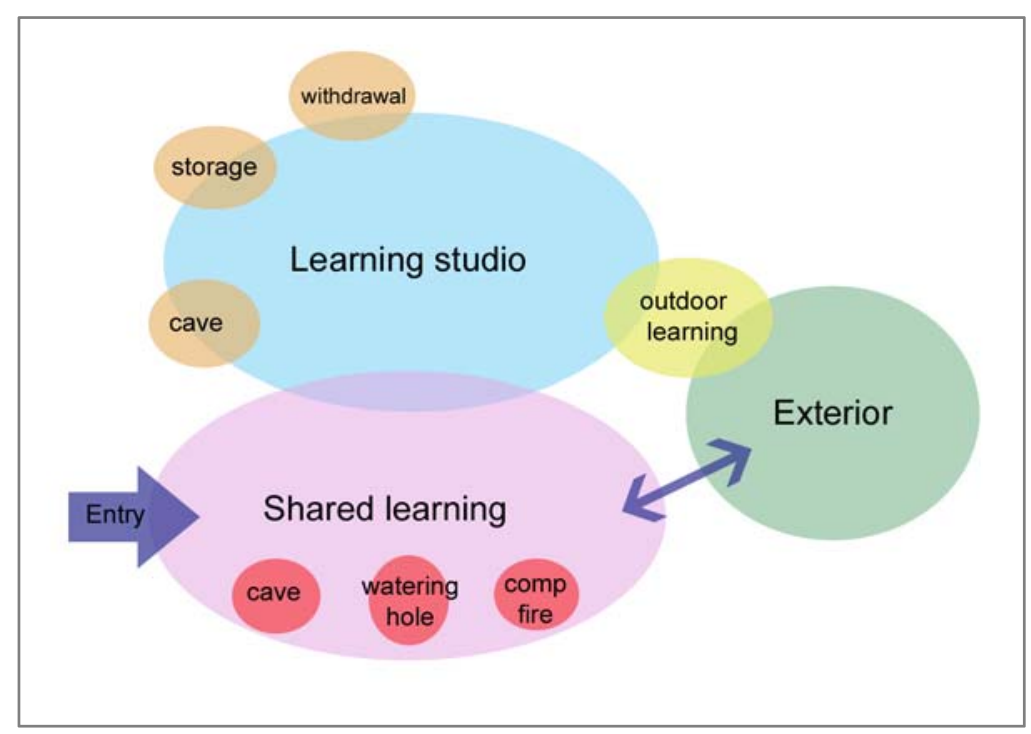

FIGURE 4-21: THE RELATIONSHIPS IN LEARNING STUDIOS. DeVeloped from Babbage Architects and Ministry of EDUCATION (2012).

The guidelines provide tips and rules for designing the learning studios, such as the need to consider viewing angles to the white board and having moveable walls between studios to enable collaboration between classes.

The codes and standards provided in the guide are in accordance with Ministry Design Standards, the Building Code of New Zealand, New Zealand Standards, Codes of Practice, and the BRANZ / Ministry of Education "Design Quality Learning Spaces" guidelines (see section 4.2.2). Like many studies of learning environments in New Zealand, the guidelines and standards are mainly about room temperature, lighting, acoustics, and finishes. There is, however, a small paragraph in the guide about furniture and equipment to be used in learning spaces. The information 
states furniture should allow for different arrangements and layouts that enable students to learn via the three modes. The guide suggests having a group of desks and tables in different sizes to suit different students. It also suggests having soft settings in some spaces, such as the shared learning area (Babbage Architects and Ministry of Education, 2012). Figures $4-22,4-23,4-24,4-25$, and 4-26 show the five pilot projects related to learning studios in New Zealand primary schools. All of them are new buildings and none were general single cell classrooms converted to learning studios.

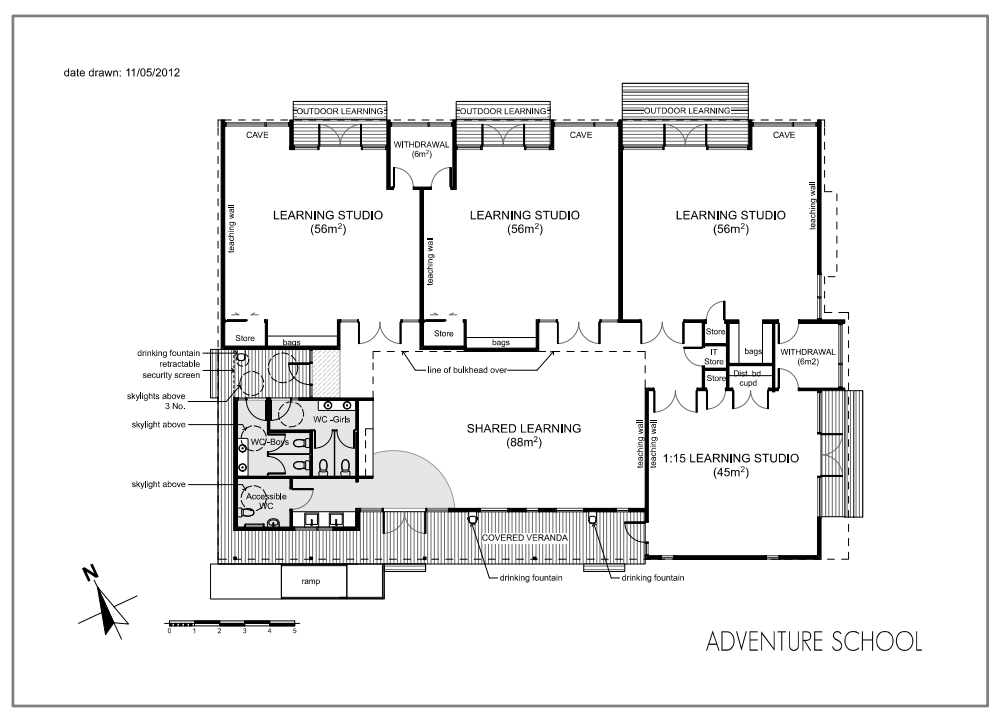

Figure 4-22: The LeARNing STUdios in Adventure School. (SUPPLIED by MINISTRY OF EDUCATION PRIVATELY). 


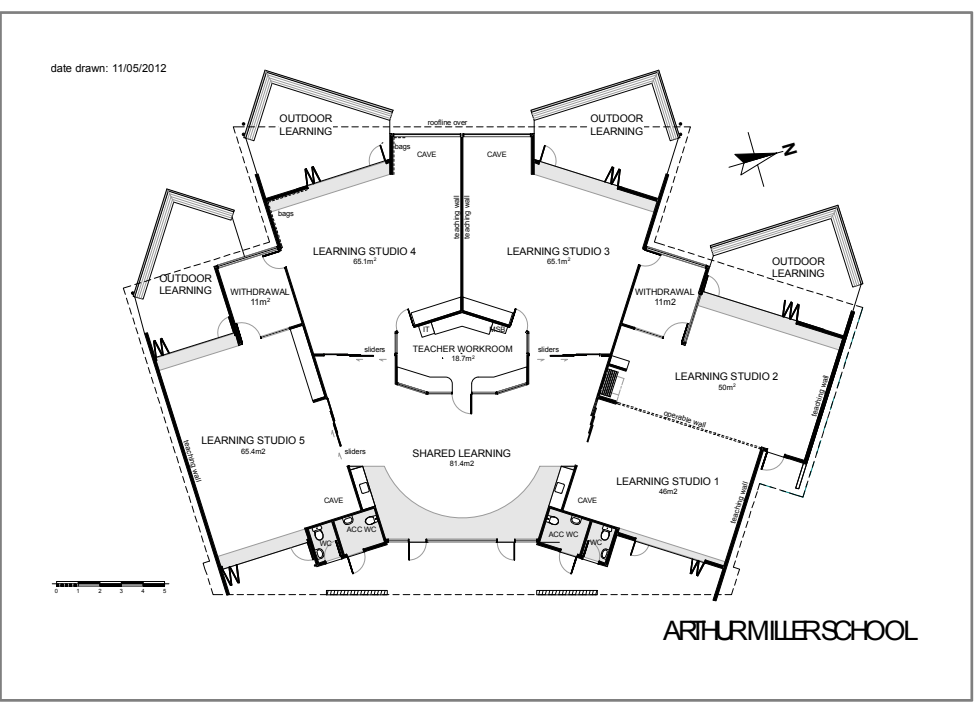

Figure 4-23: The learning Studios in Arthur Miller School (SUPPLIED by MINISTRY OF EDUCATION PRIVATELY).

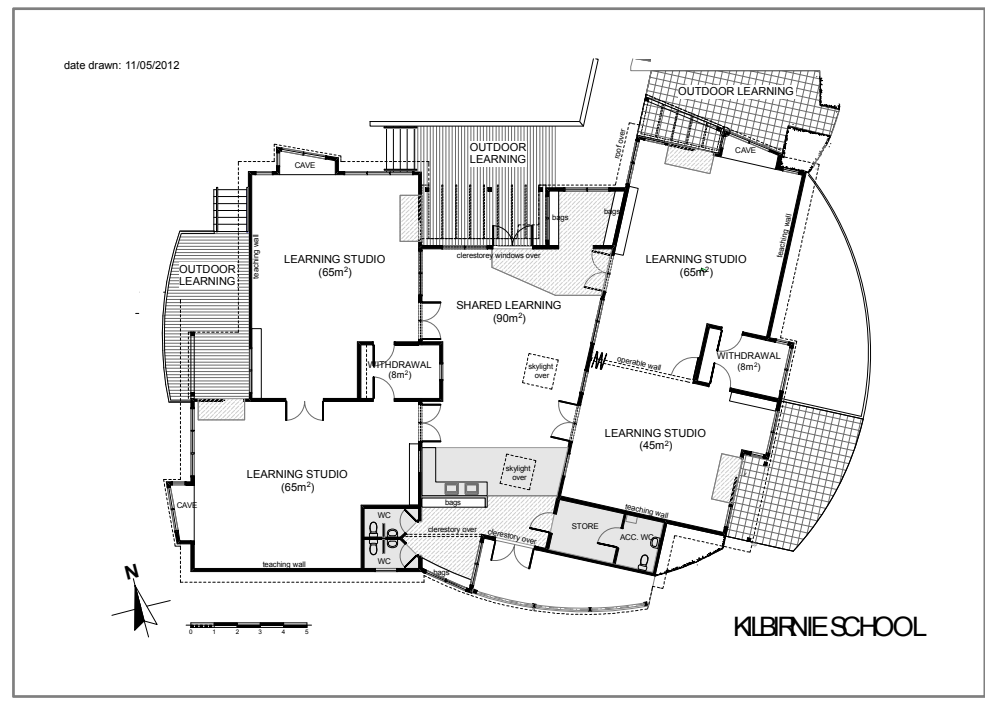

FigURE 4-24: THE LEARNING STUdios IN KILbIRNIE SCHOOL (SUPPLIED By MINISTRY OF EDUCATION PRIVATELY). 


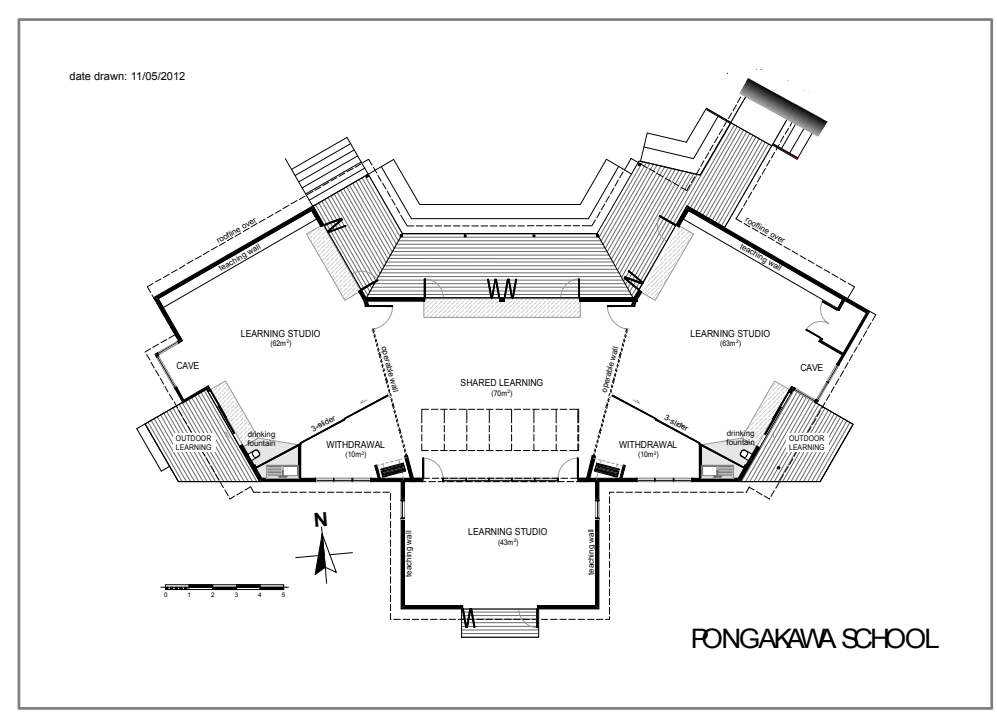

Figure 4-25: The learning Studios in PongaKawa School (SUPPLIED By MINISTRY OF EDUCATION PRIVATELY).

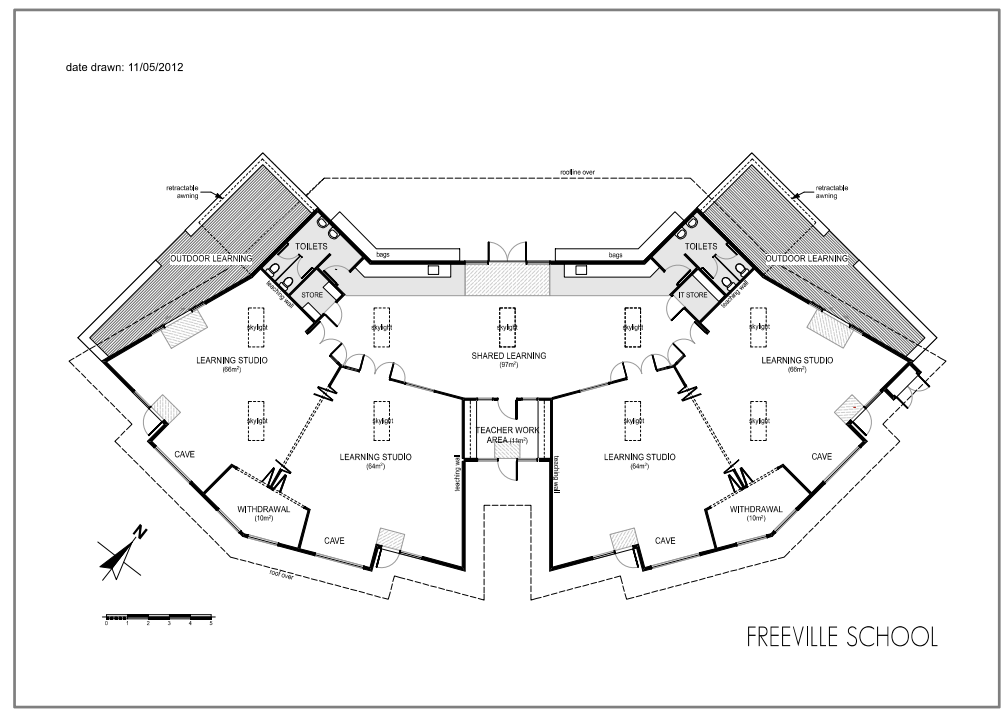

Figure 4-26: The LEARNiNg STUdiOS IN FreEville SCHOOL (SUPPLIED BY MINISTRY OF EDUCATION PRIVATELY).

\subsubsection{REVIEW OF THE PILOT STUDY:}

The Ministry conducted a review to gather feedback about the learning studios pilot project. The review was collected from schools, including principals and staff and design consultants, and included positive outcomes, problems 
during the design process, problems in use, and consultant comments.

In terms of positive outcomes, teachers and principals claim the new learning studios provide more opportunities for improved learning outcomes. They say the shared area is not only used by studio students, but also by other students from other parts in the same school. They also claim that studios allow different teaching styles and variable learning activities to occur.

Teachers like the studios not being isolated and say they gain experience from their peers. Teachers say the leaning studios have warm environments, good acoustics, fresh air, and excellent IT.

Students love the studios, as these provide interaction with more teachers and students. Students benefit from the teachers of other learning studios as they use shared spaces and have interactive activities. Senior students assess and interact with junior students for certain tasks (Ministry of Education, 2012a).

In terms of problems during the design process, schools were not entirely involved in the design process. Some decisions were not negotiable and schools did not know how they could influence the designs or if they would have the opportunity to influence and change these. Additionally, it seems the architects did not have a deep knowledge of educational 
requirements. The schools also did not have enough resources to purchase the appropriate furniture.

In one of the schools, students were consulted about the furnishing and design layout for the learning studios. Students wanted a design that would be a second home for them, with a kitchen and desks. However, after the architects had prepared a sketch that reflected the students' wishes, the Ministry rejected it.

The brief did not include information about the design and location of storage for coats and bags. This missing information led to different and sometimes poor solutions. Some spaces are not fit for all bags and coats, which leads to overcrowded areas in peak times. Some spaces in the sun may not be appropriate for storing lunch boxes because of overheating (Ministry of Education, 2012a).

In terms of problems in use, there are some common problems with the five pilot projects. These include a shortage of space to allow for different layouts and shortage of storage space. Spaces that were designed to be caves for withdrawal are used for storing resources. The extensive glazing of some spaces also reduced the space for storage. Teacher spaces have also been located in areas designed for other purposes, such as the cave, whereas ideally the teacher station should be located in relation to the teaching board. Outdoor areas also lack protection from sun, rain and wind. The shared area with vinyl flooring is not large enough for activities such as art. 
Other problems are encountered in some learning suites. Some fixtures and settings are not ergonomically appropriate for different age groups. Operable walls and foldable doors were not designed to be acoustically isolating, and high-level windows may cause glare on to the whiteboard (Ministry of Education, 2012a).

In terms of consultants' comments, design consultants did not comment on designing the interiors of the learning studios or the furniture layouts. However, consultants complained that a number of ideas, such as systems for IT and landscape designs, were rejected or changed because of the small budget (Ministry of Education, 2012a).

\subsubsection{LEARNING STUDIOS VISITS AND ANALYSIS}

To complete the discussion of this pilot study, two of the schools involved were visited and the floor plans of the learning studios analysed. This work is included in this literature review chapter, as it was completed before the data collection phase and was undertaken as part of the overall research design.

\subsubsection{ANALYSIS BEFORE SCHOOL VISITS}

Before visiting Kilbirnie School and Adventure School in Wellington, some initial analysis was undertaken of the floor plans provided privately by the Ministry of Education. The analysis included comments on the layouts of the floor plans and a proposed furniture layout for each to try to achieve the aims of the guidelines. These would then be compared with the actual furniture layout in each learning suite. 
In general, the floor plans of the pilot study contained many openings in the envelope of the learning spaces or classrooms, affecting the available wall space and positions for furniture. The moveable walls also gave less space and fewer options for furniture arrangement. In some floor plans there was only one option for the teaching wall (whiteboard wall), which can also limit the furnishing options. The floor plan was not furnished at all, which may create confusion as to how to furnish a learning studio and find the best furnishing options for such new learning environments.

The learning studios were furnished as an exercise using the furniture normally found in a single cell classroom in New Zealand. Some layout issues were also considered, inspired from the previous Master's study (see chapter 1) (Alsaif, 2011). The reasoning behind choosing single cell classroom furniture is to be able to compare the furniture in the real learning studios with single cell classrooms. The teacher's desk and teaching wall should have a strong relationship and be located close to each other. The teacher's table could also be oriented for complete control over the class. An art area and outdoor teaching space ideally might also have a strong relationship, as messy work could cross these two areas. Outdoor learning spaces can contain live creatures in addition to planting, and these also need some seating settings, such as benches or an appropriate ground surface. The shared learning area needs to work as a common room, lunch area, and small library. 
The furnishing process of the two floor plans was done in two stages. In the first, the learning studios were divided into zones for different learning activities (Figure 4-27). The size of the whole block in Kilbirnie is bigger than in the Adventure School, which made it easier to create larger zones inside each learning studio. Over all, the Kilbirnie floor plan works better as the location of learning studios around the shared area in Kilbirnie gives a better connection, especially with the transparency between the shared area and learning studios. In contrast, in Adventure School, the learning studios are still located around the shared area but the same degree of connection and transparency found in Kilbirnie is absent. Kilbirnie learning environments are also inter-connected, something that does not happen in the Adventure School learning studio. These connections could effectively enlarge each separate learning environment to cater for different activities that may need larger spaces. From this stage, the main difference between these learning studios and any normal single cell classroom is that all learning environments have indoor/outdoor connection in addition to the internal connections to the shared area.

The second stage was furnishing the learning studios with the furniture usually found in single cell classrooms (Figures 4$28,4-29)$. The main areas created in the learning studios are a mat area, teacher's area, desks and tables, computer station, wet area, and reading/quiet area. In addition, some connections were analysed from the learning studios plans, 
such as connection to the outdoor areas and connections in between learning studios. It seems that after furnishing the floor plans, the Kilbirnie learning environments works less well as circulation around furniture seems easier at Adventure school, although the space in Kilbirnie is bigger. This could be because there are more openings in the Kilbirnie learning environments than in those of Adventure School. The built in storage in the latter also gives more space as there was no need to include storage units in furnishing the floor plan. 


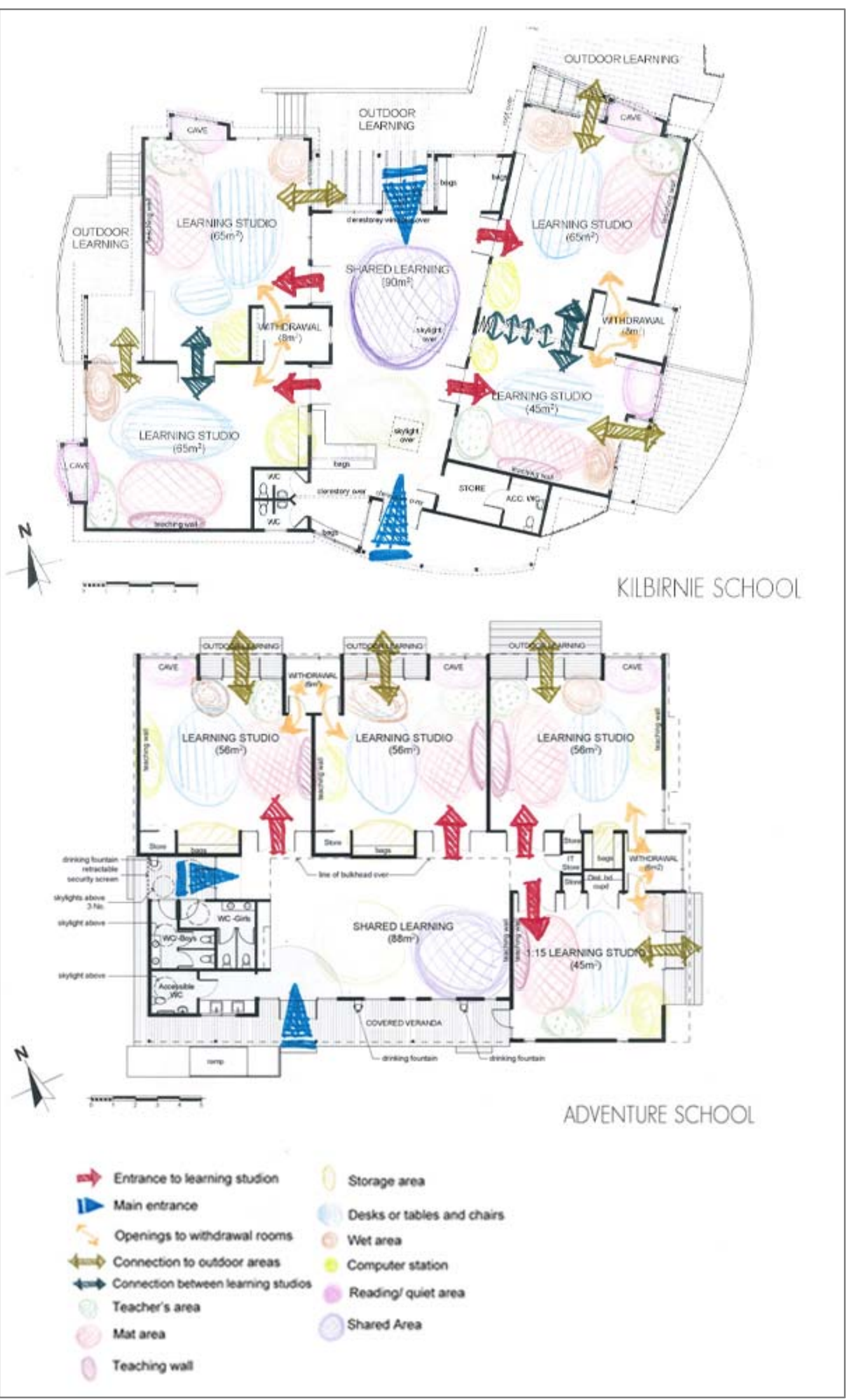

FIGURE 4-27: ANALYSIS OF THE LEARNING STUDIOS IN KILBIRNIE ANd Adventure Schools 


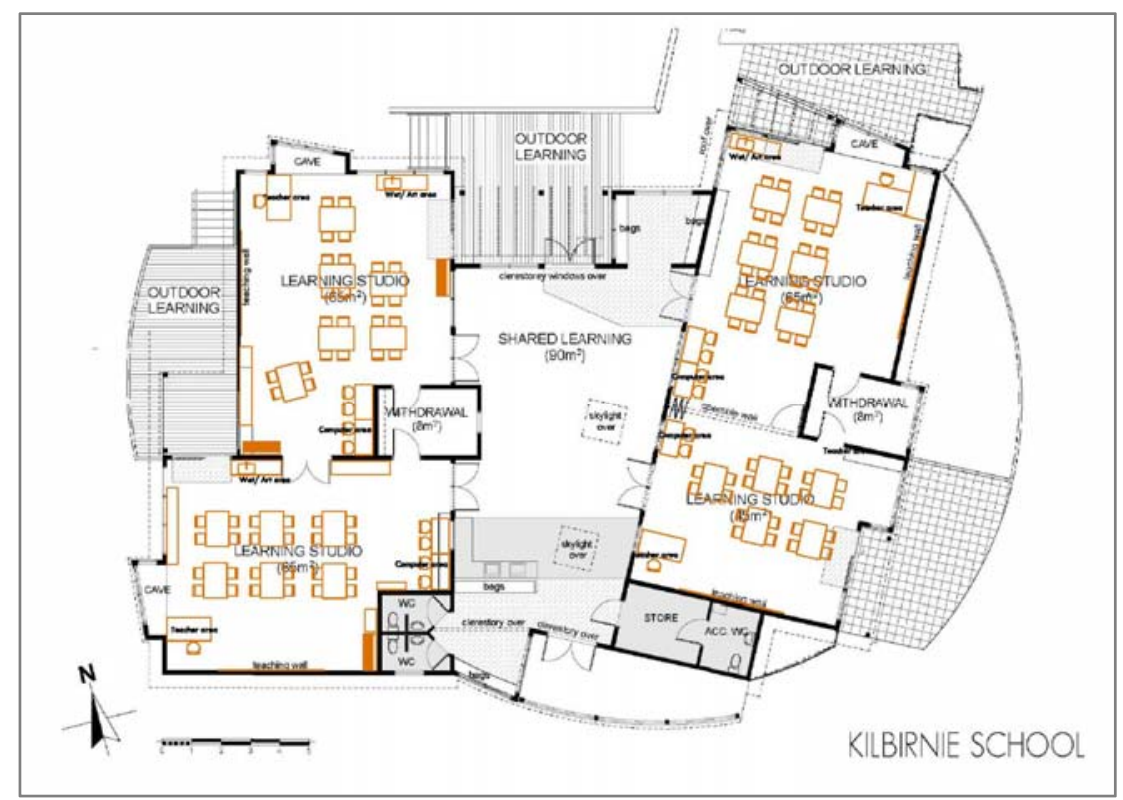

FIGURE 4-28: THE FURNITURE LAYOUT FOR KILBIRNIE SCHOOL

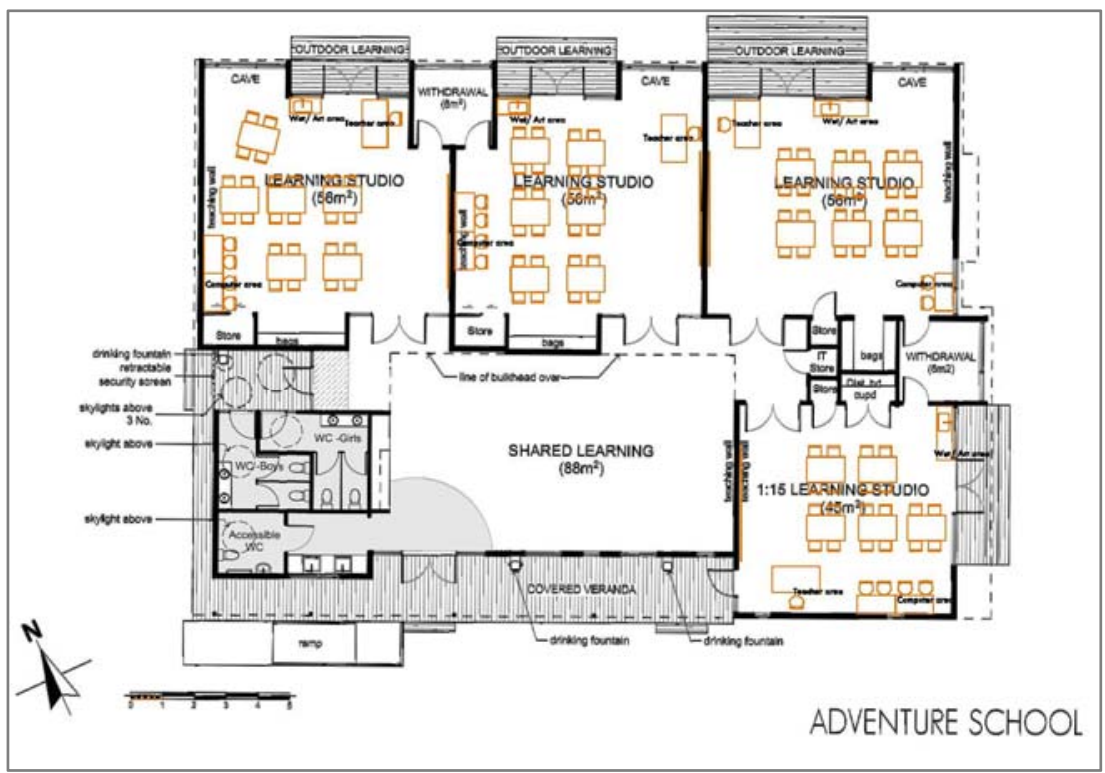

Figure 4-29: The FURNiture layout For AdVENTURE SCHOOL 
The two schools, Kilbirnie School and Adventure School, were visited after the analysis. The visits included talking with the school principals about the pilot project, visiting the learning studios, and taking photographs. Unfortunately it was not possible to draw the existing furniture layouts, as the visits were too short and school was in session. The visits were intended to provide an idea about the Ministry work and how users react to such environments and the length of time was adequate for this. Information about the learning environments in the following two sections was taken from the school principals and researcher observations.

\subsubsection{Kilbirnie SCHOOL:}

The building of the learning suite in Kilbirnie School was finished by the beginning of 2012. It is $375.76 \mathrm{~m}^{2}$ in area and caters for 73 students and 6-8 teachers. The area per student is $5.15 \mathrm{~m}^{2}$. Students accommodated in the learning studios are 56 years old.

The three main learning studios have a staff: student ratio that does not get over 1:18, while the fourth one is smaller $\left(45 \mathrm{~m}^{2}\right)$. Formerly there was one teacher for 23 students for years one and two but this has now changed to 1:18. Schools need extra classrooms to accommodate this change, so the Ministry has provided them with extra money to build new classrooms. Another change then occurred with these ratios, which lowered them further to 1:15. So the Ministry provided more funds for this second change. In addition to the Ministry money, Kilbirnie School has put money from the school into 
a fourth classroom. The fourth classroom is used as a classroom for the second half of the year because of the roll growth. In the first half of the year, the room is open to the classroom next to it.

On a daily basis, for each learning studio the people who use the space are 16-24 students, the teacher, and the teacher's aide. Sometimes, there are 6-7 parent volunteers who help students with reading.

Because of the overall new design, the school has been able to try new things such as parent volunteers teaching students in the withdrawal rooms. The learning suite is also sometimes treated as one big classroom. At other times, students and teachers are divided into closed learning studios to create four separate classrooms. With this modern design, the school is phasing out the concept of the teacher standing in the front of the class. Instead, the school is organized into learning groups.

The school's principal claims that young children need structure. Some children come to the school with behavioural issues because of different parenting backgrounds. Desks and chairs provide structure. Although the school has group tables for young students and single desks for the seniors in other normal single cell classrooms, in the learning studios children take their books or materials from their trays, which are in one of the room corners, and set out their materials on a table. Consequently, they do not have their own desks. This, in the principal's opinion, provides flexibility and structure at 
the same time. Moreover, the principal said that the chairs and tables are good for children's spines. The shared area has a combination art/wet area. Separate art areas, the principal claims, take space from each room, which could be used for other functions. This art area helps in the concept of sharing activities. Outdoors is used for lunch breaks and for outdoor teaching. There are plans to create small gardens for the learning suite in order to let students learn about gardening. The cave area in the learning studios is treated as storage in addition to its main purpose, which is a space for semi-private reading or study. Teachers have their own areas in the studios. The withdrawal rooms are used for quiet study, small group work, individual teaching, or for teacher readings. The shared area is used very often, including every day before the lunch break and at other times during the school day. It contains some tables and chairs, storage units, and some beanbags, in addition to the art area. The learning studios are provided with electronic whiteboards. The senior studios have laptops while the juniors have iPads.

The block of learning studios has good acoustics, temperature, and air quality. Other classrooms in the school have poor temperature and acoustics. However, the school is working to improve these classrooms with electronic whiteboards and ergonomic furniture. The school would like to improve the rest of the classrooms to be more like the new learning studios block but do not have the budget for this. 
Teachers change the classroom layout frequently. Usually, they change it at the beginning of the school year or semester. Children are sometimes involved in discussing the layout options.

In comparing the furniture in the real learning studios in Kilbirnie School and the hypothetical furniture layout based on what is found in cellular classrooms, there are differences. The learning studio is furnished with group tables and activity corners, in addition to the use of the shared area but there is less furniture in the real learning environments. The type of furniture also different, as the furniture used is group tables and activity zones rather than desks and chairs (Figures 4-30, 4-31).

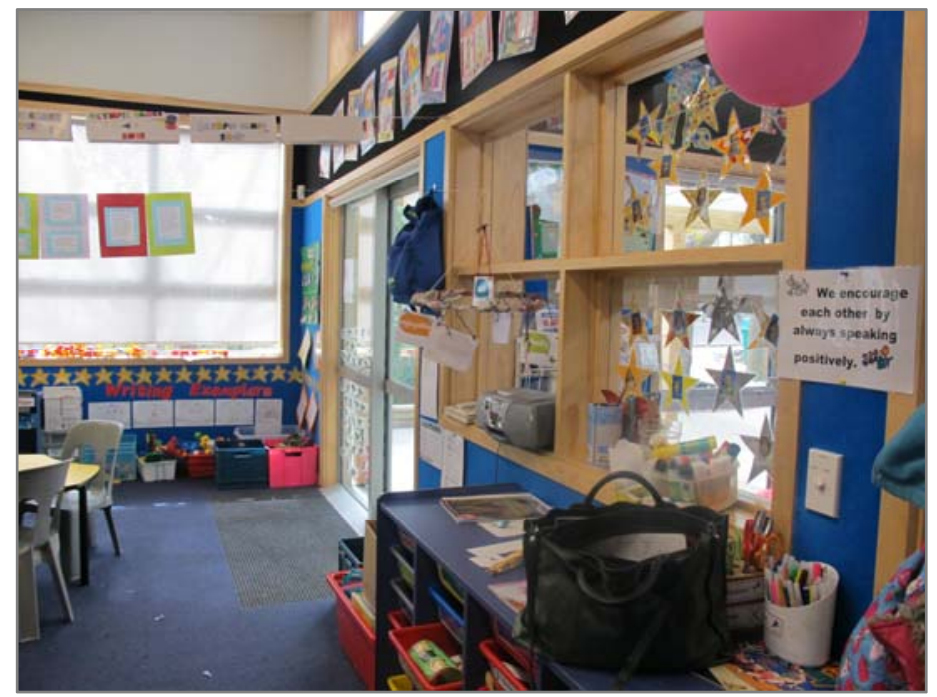

Figure 4-30: A LEARNing STUdio IN KilbirNie SCHOOL SHOWING THE TRANSPARENCY FROM THE GLAZED DOOR AND WINDOWS BETWEEN IT AND THE SHARED AREA 


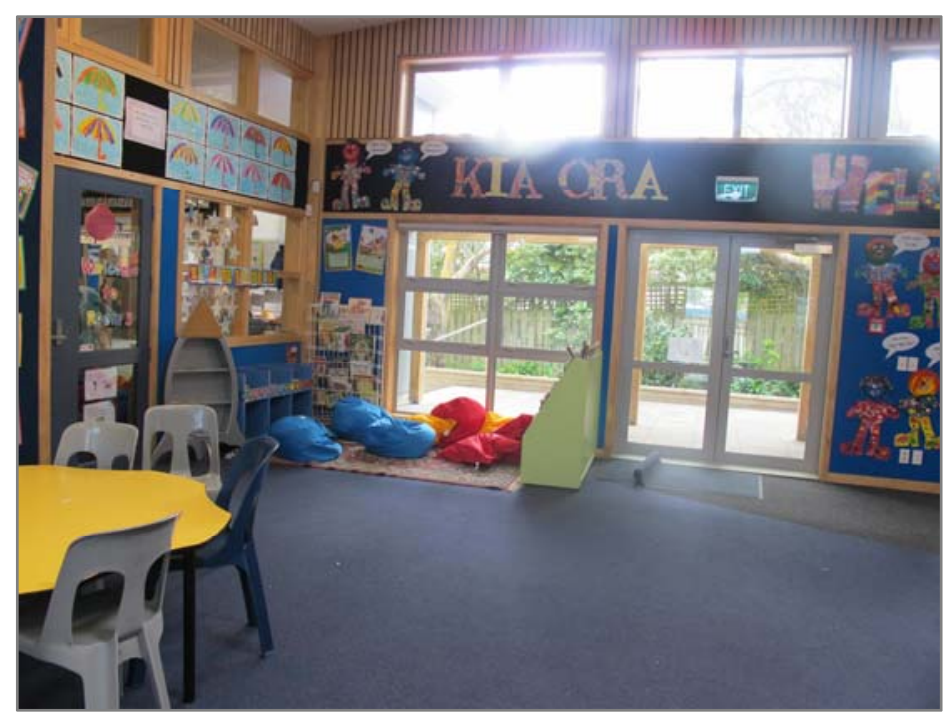

FIGURE 4-31: READING CORNER SUPPORTED BY BEANBAGS AND BOOKSHELVES AND A TABLE FOR LEARNING STUDIO GROUP WORK IN THE KILbiRNIE SCHOOL SHARED AREA

\subsubsection{Adventure SCHOOL:}

The learning suite in Adventure School was opened in 2010 with an area of $367.50 \mathrm{~m}^{2}$. It caters for 102 students and 3-4 teachers. The area per student is $3.6 \mathrm{~m}^{2}$. The block accommodates year $7 / 8$. There is one learning studio for year $1 / 2$, with a ratio of $1: 15$, but because the rest of year $1 / 2$ classes are distant from this block, the school has had to use it as an extra classroom for year $7 / 8$ or as a resource room.

There are 29 students in each learning studio. In other classrooms in the school, there are usually 27 students. The school would like bigger classrooms, but they do not have the budget.

The principal said that the biggest advantage of having learning studios is having the shared learning area, as a lot of 
activities happen in this. It consists of some seating, tables, bookshelves, a small kitchenette with microwave and water heater, and an art area. Because of the good sound insulation the learning studios have, there could be music playing and dancing in the shared area while the learning studios still work for a quiet reading session.

The new learning studio design allows students to gain experience and knowledge not only from their own teacher, but also from other teachers and students sharing the whole block. The mat areas, as the principal discussed, are very small and not large enough for all students of the learning studio. The mat is only suitable for small group work. The withdrawal rooms are used for different activities such as teacher work, quiet reading, small group work, and small group or individual teaching. Storage is still an issue in the new design. There are not enough spaces for storing the tools and resources needed in the learning studios. The cave areas are used for the teachers' desks. For art activities, there is one art area in the shared area for the whole block. There are computer plugs at the centre of the studios in addition to those on the walls, which creates more options for the location of computers and tables.

The school is trying to improve the other normal single cell classrooms to be more like the learning studio block by dividing the school into sections for different age groups. However, the existing school layout is not conducive to this. 
Teachers change the layout once every term. Involving children in furniture layouts depends on each teacher.

The inside of the learning studios is similar to the hypothetical layouts using the furniture found in single cell classrooms, consisting of desks, chairs, computer area, and mat area. The main difference is the shared area where many activities happen, such as drama, music, and physical activities. Other differences are having indoor-outdoor access and the withdrawal rooms (Figures 4-32, 4-33). Overall, the Adventure School learning studio contains more furniture than that of Kilbirnie, as there are desks and chairs for each student.

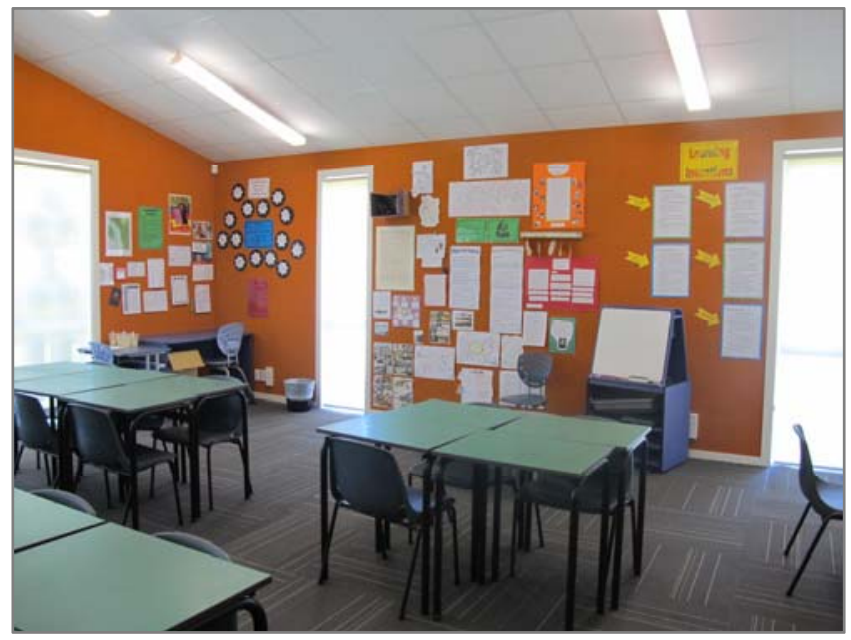

Figure 4-32: A Learning STUdio in AdVenture School SHOWING THE USE OF DESKS AND CHAIRS 


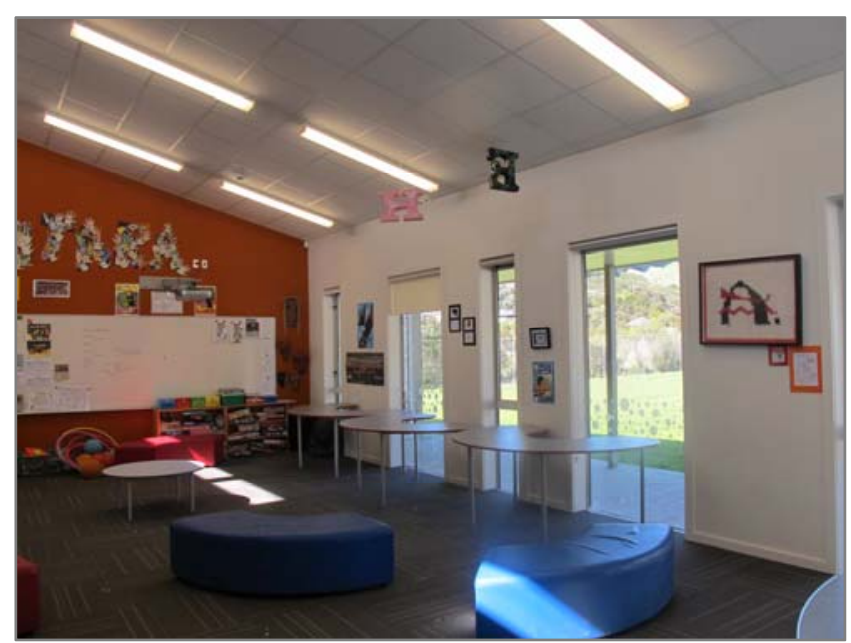

Figure 4-33: The Shared area in Adventure School With TABLES AND SEATING FOR WHOLE BLOCK GATHERINGS AND A WHITEBOARD FOR TEACHING AND LEARNING IN THE SHARED AREA

The main findings from both schools are that learning studios work better than normal classrooms in terms of using new and different teaching styles. The good sound and temperature control in the new blocks creates a huge advantage in terms of the improved indoor environment. Also, having a shared area (used for sharing skills and interactive activities) with its particular settings, such as the art zone, is a major advantage of the learning suites. The furniture layouts in the two schools differ, which is a reflection of the size of space that each school has, given that Kilbirnie School has more.

\subsubsection{Discussion of Ministry of Education WOrK}

The Ministry of Education provides information about and standards for designing learning environments. However, these standards and information do not contain enough detail to help architects and schools be confident that their decisions 
will produce better learning environments. The Ministry also provides some conflicting guidelines. For example, the modern learning environments discussed in section 4.2.3.1 are illustrated by a group of different designs. These also have different settings such as single cell classrooms with desks and table furniture layouts, and open plan learning environments with specialized activity corner layouts. The Ministry does not comment on which designs are better or how to reach the best designs, or on how to achieve these layouts in more conventional classrooms. Architects and schools might be confused by these examples, as they would not know which designs work better, and as a result they may deliver spaces that do not fulfil their specific user needs.

The Ministry's pilot project learning studios seem to be a successful step, as the schools involved are very happy with the results of these designs, although this could also be a reflection of the fact that these classrooms are new. It would be helpful if the Ministry were to take these designs and compare them to the older traditional classrooms in order to develop ways of upgrading the old classrooms to work as learning studios. However, because there is no discussion of the details of furnishing and designing the interiors of these learning studios it may be that this is not even possible. Thus, it seems schools and architects might have difficulty in applying ideas from these learning environments into existing classrooms. 


\subsection{OTHER STUdiES OF LEARNING ENVIRONMENTS IN NEW ZEALAND}

Only five further studies were found relating to the design of learning environments. The first is about designing shades to protect school children from Ultra Violet Radiation (UVR). The study discusses how students at schools are at risk of skin cancer because of the intense UVR levels. Personal sun protection such as sun hats provides some relief, although well-considered structures can provide more adequate shade and protection. The study involved investigating a group of 29 shade structures in 10 schools around New Zealand in terms of the efficiency of their UVR protection. The methodology used was a case study approach that involved surveys of management practices, interviews with the school principals, and observations of student behaviour in the outdoor areas. The study revealed that shade protection in schools could be classified into different types, such as wellestablished trees, classroom verandas, shades over playgrounds, and shades over swimming pools. The study suggested that the shade structure designs should include proper design forms and choices of shading material to suit the degree of protection for the different New Zealand climates (Mackay, 2003).

The second study by Jacqueline Mclntosh (2011) concerns air quality in primary schools in New Zealand. The research included investigating the air quality in 35 primary school classrooms in the Wellington region in New Zealand, comparing air temperature, relative humidity and air 
movement in these classrooms with the national and international standards. The investigation was completed during school days in the winter. It started by collecting information about the schools studied, including floor and site plans. Then, meetings were held with the school principals to ask them about the changes they had considered, or would consider, to improve air quality in their classrooms. Schools were visited and the general situation of the classroom air quality was observed. Following the visits, McIntosh started testing the air quality in the classrooms through a series of visits and detailed monitoring. In the last step of the investigation, McIntosh analysed the data and gave the schools feedback about the results. The main result of the research is that the classrooms studied were not designed for good air quality for the number of students they have to accommodate. There were also problems with maintenance in these schools. Improved designs and standards focussed on air quality were recommended for consideration in school design (Mclntosh, 2011).

The third study considered here is a group of studies about furniture size in New Zealand schools. In 2003, a study revealed an up to $96 \%$ mismatch between student sizes and furniture dimensions in New Zealand. It was noted that many students were seated on chairs too high for their sizes. These mismatches could cause future back pain. According to Kane et al. (2006), another research based study was carried out in New Zealand to design school furniture to be more 
appropriate for the different sizes of school students (aged 517 years). The furniture was supposed to be developed to suit student classroom activities and the physiological needs of students to move. Data was collected from 19,000 New Zealand students of different ages, heights, weights, genders, and ethnicities. The new approach proposed and used in this study depended on designing different sizes of furniture according to student stature instead of sizing by year level. This study developed and designed a chair and desk called "The Bodyfurn", which started to be used in New Zealand schools in 2005. For an appropriate relationship between the height under the desk and height of the seat part of the chair, the study suggested removing the under-desk storage and replacing it with separate storage unit. In 2003, Dr. Dieter Briethecker had discussed the physiological and educational benefits of moving around during class time. He said that when children were forced to sit in a fixed position, as in conventional chairs, they needed to move constantly to be comfortable.

As a result of the Bodyfurn study initial responses to the ideas of using different heights of chairs and desks (the proposed design and/or any older design that would meet the proposed design's main characteristics) and the removal of under desk storage were at first almost entirely negative. Some teachers complained about having more than one height of desks in a single classroom. Other teachers complained about removing the storage from under student's desks. However, schools 
and teachers agreed to try the new ideas in their classrooms for at least ten weeks. The outcome was extremely positive. Teachers reported less movement and improved focus on classwork. Students reported greater comfort. In terms of removing the under-desk storage, students and teachers were asked to create their own storage systems. In some classrooms, exercise equipment and textbooks were stored on existing shelves or containers. Pens and pencils were managed by using students' pencil cases. Positives from removing the under-desk storage, reported by teachers, are reduction in time wasted searching for books in side desks, decreased damage to exercise books, changing groups was easier as students' books were not stored in their desks, and desks became easier to move around as they weighed less. The negatives were an increase in the untidiness of the classroom as materials that needed to have ready access during activities were left on the floor or on desks. In choosing a chair suitable for each student, students were advised to use a chart to know their "weight colour". They then take the chair that has the same code colour as their height in the chart. They stand beside the highest point of the front edge of the seat, which should be no higher than a student's kneecaps. Thirdly, students try the chairs for comfort and change the size if they are not comfortable. Finally, they choose a desk with the code colour that matches the code colour of the chairs they have already chosen (Kane et al., 2006). 
The fourth study is an old study that could not be found in full, only as an abstract. It dealt with the acoustics inside classrooms and whether these were appropriate for learning and teaching. The study aimed to observe the acoustic conditions in a classroom used by students aged between 5 and 7 years in terms of the level of understanding of the teachers. The study involved visiting and observing the acoustic conditions of 106 classrooms in 51 primary schools in the Wellington region. Questionnaires were given to teachers to investigate the acoustics of the classrooms further. Sound level readings were recorded during normal classroom activities, including the teacher's voice and background noises. The analysis of the study showed that the conditions of acoustics in schools were poor and that the poor acoustics were linked with a high background noise level and the different teaching activities occurring simultaneously. The study concluded that the acoustic situations in most classrooms studied were unacceptable (Blake \& Busby, 1994).

The fifth study is a report rather than a study, again dealing with the acoustics in primary school classrooms. The report explains that primary schools have different teaching styles and activities that have to be accommodated in one space. The activities include mat activities, teaching with the whiteboard, one-to-one teaching, and group work. These different activates happening at the same time create a need for special acoustic treatments, something the report suggests in not found in primary schools in New Zealand. An experiment 
was conducted in order to gain information towards enhancing the acoustics of classrooms in primary schools. The subjects of the experiment were 18 students aged 7-9 years old. The experiment was completed in the Acoustic Research Centre's Anechoic Chamber at the University of Auckland. The subjects were asked to sit in the centre of the Chamber, 1.5 metres away from loudspeakers on stands. A number of tests were completed with different sounds and noises from the speakers while the students completed different activities such as reading and writing. Results showed that all subjects responded to the noise in a similar fashion. Based on the results of the experiment, suggestions for the design of classrooms were made. As children have almost the same reaction toward different noises, certain treatments could be installed in the classroom to enhance classroom acoustics. For example, for places for group work, a set of reflectors could be placed above the group work space. For instructing lecture-style, where the teacher stands in front of the classroom of students, sound-absorbing material could be placed on the surface behind children, as a late sound arrival problem could result from the reflections in the classroom (Whitlock \& Dodd, 2004).

\subsubsection{DISCUSSION OF STUDIES OF LEARNING ENVIRONMENTS IN NEW ZEALAND}

The studies of New Zealand learning environments discussed above indicate that the focus has not been on the internal layout of classrooms. Rather several studies discuss the environmental aspects, namely air quality, acoustics and 
shade outdoors. The study of furniture sizes is relevant to the internal design of learning environments but the study only discusses furniture sizes without any consideration of the layout of these new designs. There is thus a need for studies that discuss the internal layouts and designs of learning environments in New Zealand.

\subsection{COnclusions}

This chapter has presented all the information discovered by the researcher about research into learning environments in New Zealand. The information provided by the Ministry indicated that there is almost no focus on the internal design of classrooms. The first survey completed by the Ministry showed how it discussed and reviewed environmental treatments such as lighting and acoustics as the main factors in the successful design of classrooms. They also mentioned flexibility as one of the key aspects of good learning environments, but there was no information or discussion about what was meant by flexibility in classrooms or how this flexibility might be achieved. The discussion of furniture covered mainly tables and desks, which might indicate that the importance of having different settings for different activities, such as a couch or beanbags for reading activities, might be missed by designers. The Ministry guidelines for designing learning environments also showed that the main focus was still on the lighting, heating, ventilation, and acoustics of these areas. Even when the Ministry suggested guidelines for modern learning environments, they did not 
talk about the details of designing these, such as how much of each furniture type to include in the classroom, or how the furniture might be arranged in different layouts for different teaching styles. The guidelines did suggest having some special elements in modern learning environments, such as couches, chairs, and wireless connections, but they did not explain why and how they could help improve learning outcomes. These guidelines also discussed environmental treatments such as lighting and acoustics in more detail than the design elements and settings of modern learning environments. The investigation of prize-winning schools indicated the main focus for architects in designing schools was on the outdoors and other spaces apart from classrooms.

Before July 2014, the Ministry had examples of modern learning environments that included traditional single cell classrooms. This was confusing, as schools might not know what a modern learning environment is supposed to look like. The Ministry also provided two sets of guidelines on their website; one for learning environments in general and the other for modern learning environments. This is also confusing, as it is not clear what should be the schools' focus for the best designs for their students. If the modern learning environments were the best for learning outcomes, these should be the focus, including how they might be achieved in more traditional classroom layouts. On the other hand, the guidelines for modern learning environments did not discuss the details of their design, but only provided photographs of 
different elements in the learning environments without an understanding of how these snapshots related to the overall design. Moreover, there are no definitions or explanations of what is meant by flexibility in the learning environments. In each section in this chapter flexibility is mentioned with reference to different environments. For example, flexibility is mentioned in single cell classrooms in the examples provided by the Ministry for modern learning environments. It is also mentioned in designing learning studios in the Ministry's pilot study. Thus flexibility could mean movable walls in the first example and larger and connected spaces in the second. More focus on the aspects (flexibility) and elements (furniture) needed inside the learning environments should be made and explained in detail by the Ministry of Education.

The information and examples provided on the Ministry website show that user involvement was not considered in most schools. Even in schools that involved users in the design process, most of this was by consultation over preprepared designs. The Ministry guidelines give no information about how to involve users in the design process. In the survey completed by the Ministry, when they talked about the design process, they only mentioned consulting teachers in one stage and consulting the public at another stage. This might not be sufficient for schools and architects to know how real participatory involvement can be achieved. In the pilot study on learning studios, the guide did not mention user involvement in the design process. However, of 
the school principals in the two visited schools, one said they might involve children in changing the layout of the learning studios while the other principal said this would depend on what the teachers wanted. This suggests there is a need for guidance on user involvement of teachers and students in the design process, whether this is for a major architectural intervention or just changing the furniture layout in the learning space.

Overall, the information gathered in this chapter indicates that the user involvement in the design process is not yet properly considered in New Zealand, despite evidence it leads to better learning outcomes and better connection to the environment (see sections 3.3.1 and 3.3.2) and that there is a need to focus on the design of classrooms apart from their environmental treatments. 


\section{CHAPTER 5: RESEARCH DESIGN}

The literature review in the previous chapter led to important observations. International studies indicate that the design of learning environments can affect the learning outcomes of students. Learning environments also need to meet several standards and guidelines to boost the learning and teaching process. User participation is one of the ways to achieve better learning environments. One aim of this study is examine the design process of learning environments in New Zealand. This chapter outlines the research plan for the study the design process of learning environments in New Zealand.

The chapter is divided into four sections. The first section describes the framework of the thesis, including a discussion of the gaps in knowledge extracted from the literature review. This section also identifies the ideas emerging from these background chapters, ending with a series of questions that lead to the main research question. The second section discusses the research question and the sub-questions that help in answering the main question. The third section describes the scope of the study. The fourth section discusses the methods used to achieve the thesis aim. This section also explains the reasons for choosing multiple methods of research instead of focusing on a single method.

The ethics committee of Victoria University has approved the various stages of this research (See Appendix A). 
Members of the Ministry of Education looked at the proposed study and offered their support both before it was conducted and during the research process, hoping for results that can benefit the design of learning environments in New Zealand.

\subsection{THE FRAMEWORK OF THE STUDY}

This research is an extension of a Master's study (see chapter 1) (Alsaif, 2011). This earlier study was used as a starting point for the current investigation into the layout of primary school classrooms. In the Master's study it was found that children learn in different ways (the theory of Multiple Intelligences (Armstrong, 2009)). Based on a very small sample, classrooms in New Zealand probably only support a few intelligences. However, the new Ministry of Education learning studios initiative (see section 4.2.4) may support more intelligences. The pilot study for these learning studios suggests classrooms designed to include areas known as cave, watering hole, and camp fire increase learning experiences. These three settings support individual, small group, and large group and whole class teaching and learning in one area. Through its projects and studies the Ministry is working towards improving the quality of learning environments. However, a focus on involving the users in the design, or participatory design, has not been a priority in the Ministry's work (see section 4.3). On the other hand, the Ministry of Education's learning studios project may be shown to provide the ideal New Zealand learning environment in primary schools. If these learning 
studios are the best, how far are normal New Zealand classrooms from this concept?

The literature review reveals that it is very important that classrooms have a furniture layout that allows children to produce the best possible learning outcomes. The relationship between the quality of classroom design and student learning is already proven in a number of studies from around the world. Other studies provide examples of involving students and teachers in the classroom design process (see section 2.2.2). The interior designs in these examples perhaps more thoroughly represent the users' needs. The literature also provides information about the importance of participatory design for more efficient learning and teaching. Especially when designing for children, designers and architects need the user experience of using such spaces in order to design according to the user requirements (see chapter 3).

In New Zealand, there are almost no studies of classroom layouts. Rather, the studies about learning environments in New Zealand focus on environmental issues such as acoustics, natural lighting, fresh air, and temperature. Even the learning studios pilot project completed by the Ministry did not focus on furnishing these environments and creating good internal layouts (see section 4.2.4). These studies also indicate that classroom users (teachers and students) have not often been involved in the design process. In general, there is less care about the internal layout in New Zealand studies. From observations made in the earlier Master's study, 
teachers are supposed to be responsible for the classroom layout and furniture arrangements. So on one hand, learning environments in New Zealand are not studied enough, while on the other there is also a lack of concern about the role of users in designing learning environments. This leads to a number of questions. Are there guidelines for the ideal classroom layout? Do teachers at least have options in selecting classroom furniture and the subsequent internal layout? Would it be better if they were involved in the earlier stages of the design process? Would it be better if classroom internal layouts were discussed during the design process with the users? Figure 5-1 provides a diagram that summarizes the components that created the research problem.

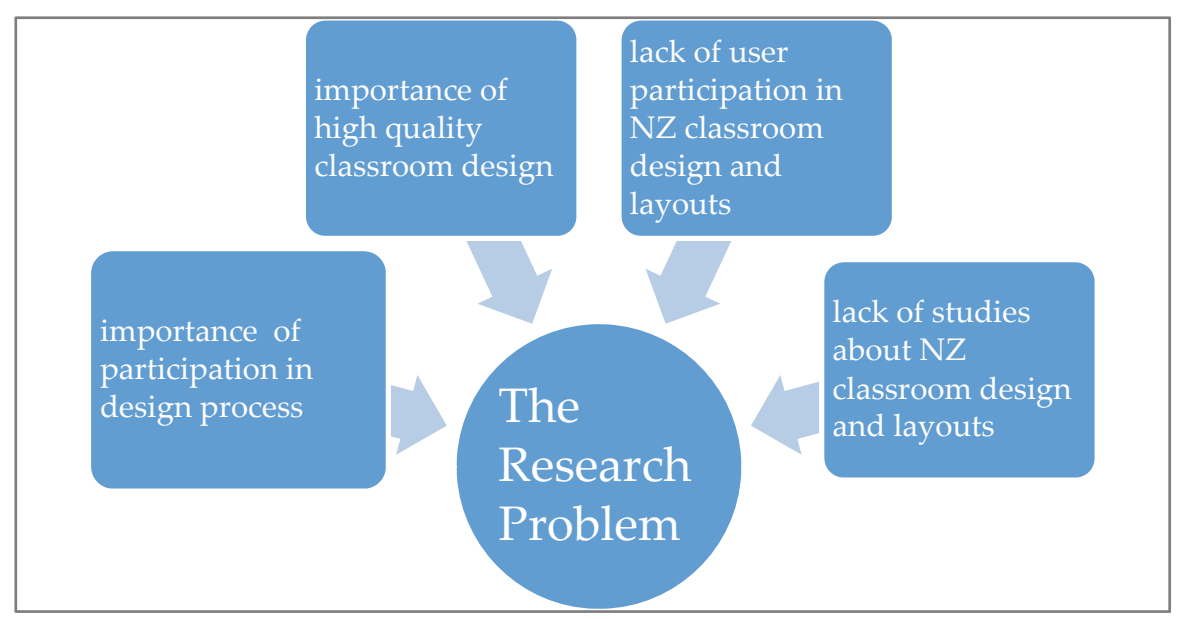

FIGURE 5-1: THE RESEARCH PROBLEM COMPONENTS.

\subsection{RESEARCH QUESTION}

As discussed earlier (see section 1.2), the aim of this research is to create an understanding of the design process behind 
primary school classroom learning environments in New Zealand. The literature review revealed a lack of studies about learning environments in New Zealand, suggesting more studies, especially of classroom interiors, are needed. This study could focus on designing better learning environments for young New Zealand students but if it only, as a consequence, suggested a number of ideal designs for learning according to international and national design standards and studies, would the recommendations be ideal for all New Zealand regions? Would they be suitable for all schools and their differing teaching strategies? The literature also suggests that designing should be a shared process between designers and users to achieve designs that fit users' needs. So instead of focussing on ideal designs, this study looks for ways of improving the design process to allow more user involvement. Taking the apparent gap in knowledge which led to the series of questions in the previous section, the major two-part research question for this project becomes:

What lies behind the design process of the current layouts of New Zealand primary school classrooms? How could the design process be improved for better perceived learning outcomes?

Answering these questions involves finding out how classroom internal layouts currently work in terms of meeting user needs. Within this two-part main question, groups of sub-questions emerge.

Questions related to current interior classroom layouts: 
- Who sets out the classroom interior and how and why do they make choices?

- Do teachers see a relationship between classroom layouts and learning outcomes?

- Do teachers have options for selecting classroom furniture and the subsequent internal layout?

Questions relating to the design process:

- Do teachers assume that it would be better if users (teachers and students) were involved in the design process of learning environments?

- Do designers have enough resources to involve users in the design process?

- What are the current methods used for participatory design of learning environments?

In answering these questions, conclusions about the design process, including weaknesses and gaps in the process, can be drawn.

\subsection{ResEARCH SCOPE}

The research question focuses on analysing the elements of the design process of learning environments. It investigates the design process in general and the involvement of users in the design process specifically. In this context, user involvement includes the relationship between architects and designers and teachers, in addition to the methods used to involve young students in the design process. The design process could be as small as changing the classroom furniture layout or as big as a new or re-built entire school project. However, here the learning environments involved in the investigation are primary schools in New Zealand, with a 
special focus on the classrooms of these schools. Architects involved in school design throughout New Zealand are also part of the research. Although the study covers primary schools from all over New Zealand, some more detailed investigations are focused on primary schools in Wellington City, for ease of continuous access. The study also seeks ways to improve the design process. This includes trying different methods to involve users in the design process and again the focus here was on participation of primary schools from all New Zealand.

All spaces within school buildings are important for learning and teaching. However, classrooms are more frequently used as observed in the researcher's Master of Architecture study (Alsaif, 2011) and the POE study of Manchester schools in section 3.5. In fact observation shows the majority of the school day is spent inside classrooms despite the different types of learning spaces in the school (outside space, hall, art space etc.). As this is the first study of its kind in New Zealand, it seems suitable to start by first focusing on classroom environments and look at other spaces and facilities in schools in future studies. There are many factors within a classroom design that could affect the learning process. Environmental aspects such as lighting, air quality, and acoustics are very important and should be considered in all interior designs, as ignoring even one of them could result in a poor environment. Many researchers have covered these aspects internationally and a number of local researchers have 
also covered them (you should have some references here). In contrast, research into the internal design of classrooms has barely been tackled, especially in New Zealand. For the design of schools in New Zealand, architects, the schools themselves, and the Ministry of Education, claim that the budget is not enough to cover all they might wish in terms of the changing the details of the interior design. They normally have no budget to repaint the walls, change the materials of finishes, or change the furniture. Thus, this thesis focuses on the things that cost nothing but that can produce change in the internal design. This means having a focus on the internal furniture layout and dealing with the existing furniture in existing school buildings and classrooms.

There are some aspects related to designing schools and classrooms, such as environmental psychology, which is defined as "the study of the interrelationships between the physical environment and human behaviour" or "the study of transactions between individuals and their physical settings" (Cassidy, 2013). This psychological side of the design learning environments has important effects on the behaviour of users and then on their learning outcomes. Another aspect that could be part of designing learning environments is biophilia, which is 'love of life or living systems" (Simaika \& Samways, 2010). Considering biophilia in designing learning environments could have a vital effect on the indoor to outdoor connections of school buildings. It could create a wide range of designs that allow nature inside 
built learning environments. However, although both environmental psychology and biophilia have something to offer classroom design, because this is the first study of user involvement in New Zealand and because the conventional classroom is where New Zealand children spend most of their school day, these aspects are left for future studies building on the results of this one.

\subsection{Selection of methods}

This study is a qualitative research investigation because it aims to collect information to form a new understanding of the design process behind learning environments in New Zealand (Groat \& Wang, 2002). As this study aims to collect information that does not have enough background knowledge to form a theoretical framework, the methodology chosen is an exploratory one (Groat \& Wang, 2002). The first step in this investigation or exploration is to discover what currently happens in New Zealand classrooms and whether teachers and architects support the involvement of users in the design process. Following this first step, a series of studies provides more information about the design process of learning environments in New Zealand, and these will also be compared with the results of the first investigation. The following sub-sections provide a summary of the methods used in each small study and the sample selected for the whole study. 


\subsubsection{METHODS}

Triangulation is used in this study, which means using multiple methods to achieve 'one point', this representing the answer to the main research question (Evans \& Gruba, 2007). Triangulation is used here because the study needs more than one research method to answer the main question. The research question is multi-faceted and different approaches are needed to shed light on its different aspects. As this field of study is not yet sufficiently investigated, a number of studies are needed to support the results from different directions.

After finding the gap in knowledge and defining the question and aim of the study, this thesis proceeds by setting up a number of small studies to collect sufficient information to answer all the research questions. Each study has its own hypothesis or question. The research has five phases that are explained only briefly here. The first phase is an investigation into the primary school design process in the form of two surveys. The second stage is an experiment or trial of a change to the design process to make it more participatory through using social media. The third phase is further investigation that builds on the results of the previous investigations through discussing the results in a focus group. The fourth phase is a case study based on observation of the design process for an architectural project for remodelling an existing primary school that was intended to include user participation. The final stage is also a case study, here 
observing the design process through a participatory redesigning of the internal layout of two primary school classrooms. The table below gives a brief description of each phase.

TABLE 5-1: THE DIFFERENT PHASES AND METHODS USED IN THIS STUDY

\begin{tabular}{|c|c|c|c|}
\hline $\begin{array}{l}\text { Research } \\
\text { phase }\end{array}$ & Method & The aim & Time \\
\hline Phase one & $\begin{array}{l}\text { Survey } \\
\text { (two surveys, } \\
\text { one for } \\
\text { teachers and } \\
\text { one for } \\
\text { architects) }\end{array}$ & $\begin{array}{l}\text { Investigate the design process of } \\
\text { learning environments and the role } \\
\text { of teachers and students in the } \\
\text { process }\end{array}$ & June/July 2013 \\
\hline Phase two & $\begin{array}{l}\text { Experiment } \\
\text { (social media) }\end{array}$ & $\begin{array}{l}\text { Investigation of the use of social } \\
\text { media to aid the involvement of } \\
\text { teachers and students in the design } \\
\text { process }\end{array}$ & $\begin{array}{l}\text { Started July } \\
2013\end{array}$ \\
\hline $\begin{array}{l}\text { Phase } \\
\text { three }\end{array}$ & $\begin{array}{l}\text { Focus group } \\
\text { (workshop for } \\
\text { architects and } \\
\text { teachers) }\end{array}$ & $\begin{array}{l}\text { Discussion of suitable methods for } \\
\text { users to be involved more in the } \\
\text { design process of New Zealand } \\
\text { learning environments }\end{array}$ & 29 March, 2014 \\
\hline
\end{tabular}




\begin{tabular}{|llll|}
\hline $\begin{array}{l}\text { Phase } \\
\text { four }\end{array}$ & $\begin{array}{l}\text { Case study } \\
\text { (Architectural } \\
\text { project) }\end{array}$ & $\begin{array}{l}\text { Observing the process of a primary } \\
\text { school rebuilding project and the }\end{array}$ & $\begin{array}{l}\text { January- } \\
\text { involvement of users in it }\end{array}$ \\
\hline Phase & Case study & Observing and facilitating the & May-June 2014 \\
five & (classroom & design process regarding \\
& internal layout & rearrangement of two classroom & \\
& rearrangement & furniture layouts by the teachers and \\
& students of these & \\
& & & \\
& &
\end{tabular}

The phases were not completed in the order shown in Table 5-1, although all were completed between June 2013 and June 2014. The reason for adjusting the order of the phases as shown in Table 1 is that the new order, with the connections between the results of the different phases, is more logical and coherent than the original one. All phases are explained in detail in the following two chapters, where the methods used for each phase are also discussed. The reason for this is because each phase depends on the results of the previous phase(s).

\subsubsection{SAMPLES}

The investigations and studies focus on primary school classrooms, particularly the middle year classes (years 3-4 and 5-6). This focus on primary school classrooms is because the study is about involving young students and their ability to be part of a participatory design process, as opposed to adolescents or adults, as in secondary and tertiary education. The middle classes of a primary school were selected for two 
reasons. The first is that the same year groups were involved in the research for the Master's thesis and it was felt it would be appropriate to choose the same sample, as this research grew out of this first studyThe second reason is that the age of students in these classes (7-11 years) is suitable for activities that involve dealing with students during a research process. The first step was to create lists of all primary schools in New Zealand, with their contact details. The next was to make a similar list of architecture practices who had undertaken educational projects in New Zealand (the lists are provided in the $\mathrm{CD}$ accompanying the thesis). Extra details about the samples for each study, in addition to the method and reasons behind selecting the samples, are also provided in the following two chapters (6 and 7). The samples are explained in the methods section of each study.

\subsection{SUMMARY}

The background chapters revealed a gap in knowledge in terms of the lack of learning environment studies that focus on the internal layout and the involvement of users in the design process of learning environments in New Zealand, when compared with overseas studies, and that the fact the latter stress the importance of having high quality learning environments and good user involvement for improved learning outcomes. An exploratory methodology using multiple methods has been chosen for conducting this study. The methods are undertaken in five phases that, when combined, answer the research questions. The five phases are 
surveys, an experiment, a focus group, a case study of an architectural project, and a case study of internal layout rearrangements. Details of these phases, methods, samples, and reports are provided in chapters 6 and 7 . 


\section{Chapter 6: Phase ONE: SURVEY OF TEACHERS AND ARCHITECTS}

This chapter presents the first phase of the research towards achieving the aim of this thesis. It describes the beginning of the investigation into the design and design process of learning environments in New Zealand. It presents the data collected from the two surveys of architects and teachers, the analysis of that data, and where appropriate compares the results and discussing the outcomes. The aim of this chapter is to discover something about the design process behind learning environments in New Zealand primary schools. The chapter also presents problems and issues with the design of these learning environments that emerged through the surveys.

The chapter is divided into four sections, with the first a discussion of using a survey as the method for this phase of the research. The next section reports on the results of the teachers' survey, while the third section does the same for the architects. The final section compares the results from questions common to both surveys. Where the findings are presented, the responses to the survey questions covering similar information are grouped into sub-sections. In each sub-section the data collected for each question is first presented separately and then discussed for the group of questions at the end of the sub-section. 


\subsection{SurVey METHOdS FOR PHASE ONE}

An on-line questionnaire was the survey method chosen for this phase of the research. To start it was necessary to have the opinions of teachers on classroom layout, classroom design and the design process behind learning environments. The intention was to ask architects, again using an on-line questionnaire, how they set about designing classrooms and about user participation in learning environment design. Other possible methods of gaining this information, such as observation and interviews, were too difficult for collecting information from primary school learning environments all over New Zealand. According to Fink (2003), surveys are used for collecting information and to describe, compare, or explain information. This desired information could be knowledge, attitude, or behaviour, all of which were needed to assess the current state of learning environment design. Thus a survey was the best method for completing this phase of the research.

Features of the best surveys include having specific objectives, straightforward questions, a good research design, a good choice of audience or sample, reliable survey instruments, and truthful report of the survey results (Fink, 2003). The following sub-sections discuss these elements in more detail. 


\subsubsection{Aim OF PHASE ONE}

Defining objectives for the survey is important for knowing what type of question should be included and what information is needed. From the objectives of the survey, the main terms relating to the objectives can be determined. These terms can lead to survey questions by focusing on what is important about these terms in relation to the main study and what sort of information about these terms is important and valuable (Fink, 2003). To achieve the thesis aim of creating an understanding of the design process behind primary school classroom learning environments in New Zealand, this phase aimed to collect basic information about their design and the design process behind them. It was felt this aim could be achieved by surveying architects about the design and design process in general and teachers about design and user involvement in the design process.

\subsubsection{TARGET SAMPLE}

There are two main types of sampling methods, probability and non-probability. The probability method provides a representative sample of the population and uses random selection. Probability sampling includes simple random sampling, stratified random sampling, systematic sampling, and cluster sampling (Fink, 2003). Non-probability sampling selects the samples by judging the type of target population and the objectives of the survey. However, some people that are eligible targets might be not chosen which potentially makes the survey findings inaccurate. Having a target population was the course taken with these surveys but to 
make them as accurate as possible, lists of all primary schools in New Zealand and lists of all architectural offices that work or have worked on appropriate educational projects were created. The school lists included the school name, school type, location, and contact details. The list of architectural offices included practice name, location, and contact details (available in attached CD).

The teacher's questionnaire was sent to all 2036 primary schools via email. A letter accompanied the message explaining the aim of the survey and asking that it be passed to year $5 / 6$ teachers, who are the target sample of this thesis.

For the architect's survey, the offices were first contacted by telephone to introduce the survey and its objective and collect the e-mail addresses of interested practices. As a consequence the architect's questionnaire was sent to the 60 email addresses. Almost all practices accepted to participate in the survey. Only one practice refused because they did not have time for the survey.

\subsubsection{PREPARING THE SURVEYS}

There are various possible initial preparations that can be undertaken when preparing a survey. Experts on the survey topic could be questioned about their knowledge and experience to ascertain what the important issues might be. These experts could be questioned by mail, telephone, or in meetings. The latter fall into two types, focus groups and consensus panels, both of which can be helpful in determining the objectives of the survey and defining their 
roles in the main study. A focus group can contain up to 10 people, with a trained leader. The discussion should be planned previously and stick to the area of interest in order to uncover the needs and objectives of the survey. A consensus panel can contain up to 14 people, again with a skilled leader. The meeting should be highly structured. For example, the panel members may need to read documents and rate preferences (Fink, 2003). Because the surveys in this research are trying to discover new knowledge, it was not appropriate to choose consensus panels for the survey preparation. Thus, focus groups were conducted to discuss the objectives of the survey, one for teachers and one for architects. These are not the same as the focus group in phase 3 of the research (see section 5.4.1). The main aim of the early focus groups for teachers and architects was to encourage participants to speak freely about their experiences and concerns about using and designing the internal layouts of learning environments. These focus groups were digitally-recorded.

Teachers of all primary schools in Wellington City were invited to participate in the first focus group on 22 January, 2013 but only two teachers could attend the session. The session took about one hour and was held in a seminar room at Victoria University of Wellington. The questions in the focus group session were open questions about the existing use of classroom layouts and any experience the teachers had of being involved in a design process (see appendix B). The discussion involved many topics, such as the furniture of the 
classroom, experiences of designing learning environments, and activities completed in the classrooms, in addition to questions about creating a questionnaire suitable for teachers. The discussions in this small focus group led to questions in the survey, as summarised in Table 6-1.

TABLE 6-1: QUESTIONS INSPIRED BY THE TEACHER FOCUS GROUP DISCUSSIONS

\begin{tabular}{|l|l|}
\hline Discussion & Survey Questions \\
\hline $\begin{array}{l}\text { One teacher said that furniture and location } \\
\text { style, especially since they must deal with }\end{array}$ & classroom? \\
the furniture that they have in the school. & \\
They would like to choose the furniture that & Who chose the location of the \\
suits them best and can support their & fixtures (e.g., sink/power \\
teaching styles, and the location for the & points) in the classroom? \\
fixtures so they can arrange the furniture & \\
freely. & Who chose the furniture for the \\
\hline $\begin{array}{l}\text { Teachers' contributions in the design } \\
\text { process did not change or affect the designs. }\end{array}$ & that has been renovated while \\
The principal was controlling and & you were there? \\
\hline
\end{tabular}




\begin{tabular}{|c|c|}
\hline Discussion & Survey Questions \\
\hline & $\begin{array}{l}\text { Is the principal of the school } \\
\text { the decision maker in the } \\
\text { design process? } \\
\text { Do teachers have a chance to } \\
\text { talk with architects? } \\
\text { How would you like to } \\
\text { participate in the design } \\
\text { process? }\end{array}$ \\
\hline $\begin{array}{l}\text { Teachers discussed that they learned in } \\
\text { traditional classrooms and learned to be } \\
\text { teachers for the same types of } \\
\text { environments. Teachers may stick to what } \\
\text { they already know. Visiting and working in } \\
\text { other environments such as open plan } \\
\text { classrooms may change teachers' opinions. }\end{array}$ & $\begin{array}{l}\text { Did learning to be a teacher } \\
\text { prepare you for teaching in } \\
\text { traditional classrooms? } \\
\text { Have you visited other schools } \\
\text { with learning environments } \\
\text { different from your own? } \\
\text { Have you used things you } \\
\text { observed in visits to different } \\
\text { learning environments? }\end{array}$ \\
\hline $\begin{array}{l}\text { One teacher said that they change the } \\
\text { internal layout once a term. She said that } \\
\text { they ask students to help them in the }\end{array}$ & $\begin{array}{l}\text { How often do you make major } \\
\text { changes to the furniture layout } \\
\text { of your learning environment? }\end{array}$ \\
\hline
\end{tabular}




\begin{tabular}{|c|c|}
\hline Discussion & Survey Questions \\
\hline $\begin{array}{l}\text { change. They also asked students to help in } \\
\text { choosing the furniture in the first place. }\end{array}$ & $\begin{array}{l}\text { What are the things that most } \\
\text { influence the layout of your } \\
\text { learning environment? } \\
\text { Are students involved in the } \\
\text { classroom furniture } \\
\text { arrangement? }\end{array}$ \\
\hline $\begin{array}{l}\text { Teachers did not know about the guidelines } \\
\text { provided by the Ministry of Education (see } \\
\text { section } 4.2 .2 \text { ) }\end{array}$ & $\begin{array}{l}\text { How frequently do you check } \\
\text { the Ministry guidelines on } \\
\text { classroom design (if you know } \\
\text { about them to begin with)? }\end{array}$ \\
\hline
\end{tabular}

For the architects' focus group, an invitation was sent to all practice offices in Wellington City that are working or have worked on educational projects. Only two architects could attend the session, which took about one hour and was held in a seminar room in Victoria University of Wellington on 11 December 2012. The questions in the focus group session were open questions about the existing use of classroom layouts and any experience of user involvement in a design process. The architects discussed many topics some of which led to questions on the survey (see appendix C). Table 6-2 shows how these discussions led to questions. 
TABLE 6-2: QUESTIONS INSPIRED BY THE ARCHITECTS FOCUS GROUP DISCUSSIONS

\begin{tabular}{|c|c|}
\hline Discussion & Survey Questions \\
\hline $\begin{array}{l}\text { The principals make decisions about } \\
\text { what teachers and students need. The } \\
\text { main contacts with the architects are } \\
\text { the school principals }\end{array}$ & $\begin{array}{l}\text { Is the principal of the school the } \\
\text { decision maker in the design process? } \\
\text { Do architects have chance to talk with } \\
\text { teachers? } \\
\text { Do architects have chance to talk with } \\
\text { students? }\end{array}$ \\
\hline $\begin{array}{l}\text { Some teachers have no idea how } \\
\text { learning environments affect learning } \\
\text { outcomes. The national curriculum } \\
\text { does not discuss the importance of } \\
\text { learning environments in improving } \\
\text { learning outcomes. Additionally, } \\
\text { Ministry of Education standards are } \\
\text { not supported by full knowledge of } \\
\text { learning environments and there are } \\
\text { not enough resources to support } \\
\text { architects' work. }\end{array}$ & $\begin{array}{l}\text { How frequently do you check the } \\
\text { Ministry guidelines for classroom } \\
\text { design? } \\
\text { How satisfied are you with Ministry } \\
\text { of Education guidelines? }\end{array}$ \\
\hline $\begin{array}{l}\text { Architects are normally not paid to } \\
\text { conduct post-occupancy evaluations. } \\
\text { However, some architects ask schools }\end{array}$ & $\begin{array}{l}\text { Do you conduct post-occupancy } \\
\text { evaluations of your primary school } \\
\text { work? }\end{array}$ \\
\hline
\end{tabular}




\begin{tabular}{|l|l|}
\hline Discussion & Survey Questions \\
\hline about their projects in order to use & \\
& $\begin{array}{l}\text { When you do a post-occupancy } \\
\text { evaluation, what are the things you } \\
\text { observe that help you most in your } \\
\text { new projects? }\end{array}$ \\
\hline $\begin{array}{l}\text { Architects do not receive budgets for } \\
\text { choosing furniture that matches their } \\
\text { designs. Some architects privately } \\
\text { offer to help in choosing appropriate } \\
\text { furniture. }\end{array}$ & School and classrooms? \\
\hline
\end{tabular}

\subsubsection{DESIGNING AND CONDUCTING THE SURVEYS}

The questions extracted from the discussions in the focus groups could have shaped a number of different investigation types, such as questionnaires, structured interviews, and standard observation. A self-administered questionnaire is a group of questions that each individual in the sample can answer independently. Interviews require an interviewer to ask questions of a respondent from the study sample, although interviews could be conducted with groups of interviewees at the same time. Structured observation collects data visually, and here the questions provide a framework for the observers to focus on particular activities or characteristics (Fink, 2003). As questionnaires are the best method to reach more individuals in a shorter time, the decision was made to 
use the questions from the focus groups in an on-line questionnaire.

The questionnaires were designed with groups of open and closed questions. The questions included all those generated in section 6.1.3, in addition to additional questions created to elicit as much information as possible about the design process of learning environments in New Zealand. The questions are grouped in sections. In the teachers' survey, the main sections are general questions about school buildings and classroom designs, questions about participatory design in learning environments, questions about existing learning environments, and questions about ideal layouts and design processes (see appendix D). In the architects' survey, the main sections are designing schools, designing classrooms, the design process in general, the Ministry of Education, and educational books and theories (see appendix E). Both surveys were conducted using the online survey software Qualtrics.

A pilot study was conducted for each questionnaire. The pilot teachers' survey was undertaken by the two teachers who participated in the focus group. The pilot architects' survey was answered by two architects, one who had attended the focus group and another architect who had been willing to attend the focus group but could not manage it on the day. The results of the pilot study did not change the design of either questionnaire. Thus, the results of the pilot surveys were included in the analysis of the main surveys. 
A statistical analysis was used for the results. Statistical analysis is organizing and interpreting numerical information and giving results as descriptions, relationships, comparisons, and predictions (Fink, 2003). SPSS software was used to complete the analysis in addition to the main analysis provided by Qualtrics.

\subsection{TEACHERS' SURVEY FINDINGS AND ANALYSIS} In May 2013 the teachers' survey was sent to 2036 primary schools in New Zealand; 248 teachers started the questionnaire but only 141 completed it, giving a very low $7 \%$ response rate. The majority of people who did not complete the questionnaire stopped after reading the introductory pages and before answering any of the questions. This may indicate that they were curious about the study but felt that they did not have time to participate. The rest of the teachers who did not complete the questionnaire stopped at various questions throughout the questionnaire, with no particular pattern emerging. The following analysis, therefore, shows the number of participants answering each question or subquestion.

The teachers' survey is divided into five sections: general questions (6.1.1), participation in the design process (6.1.2), the existing learning environment (6.1.3), ideal layouts and design processes (6.1.4), and correlations within the teachers' survey (6.1.5). 


\subsubsection{General Questions}

This section consists of 7 general questions on basic information about the current learning environment and users, such as the type of learning space and the number of users. A total of 174 teachers responded to these 7 questions, as discussed below.

The first question (Q1, n=174) is about the age of the respondents' schools. For 153 participants (87.9\%) the schools where they currently teach opened before 1990 (before Tomorrow's School Act, see section 4.2), whereas only 21 participants (12.1\%) are currently teaching in schools opened after 1990.

The second question $(\mathrm{Q} 2, \mathrm{n}=174)$ is about the type of school. Of the 174 participants who responded, $163(93.7 \%)$ are currently teaching in state schools and 11 (6.3\%) in integrated schools. There were no responses from teachers in private schools.

For the third question (Q3, n=174), about the current type of learning space of participants, 142 teachers $(81.6 \%)$ are in single-cell classrooms, $9(5.2 \%)$ are teaching in open-plan environments, $17(9.8 \%)$ are teaching in prefabricated classrooms, and 6 (3.4\%) selected "other" (Figure 6-1). One of the teachers who chose "other" said that they have a singlecell classroom with the ability to be an open plan layout. Another teacher said that they have a room with a divider. The other four teachers who chose "other" did not clearly explain their type of learning environment. For example, they 
said "two storey building" or "mixed school". There are no participants teaching in learning studios.

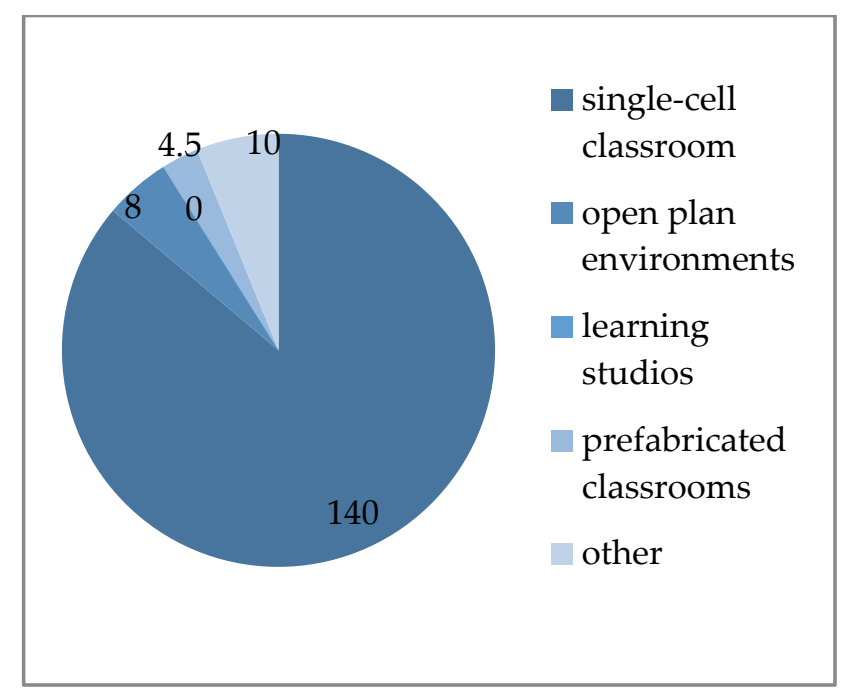

FIGURE 6-1: TYPES OF LEARNING SPACES FROM TEACHERS' SURVEY

The fourth question $(\mathrm{Q} 4, \mathrm{n}=174)$ concerns the time of the last renovation to the current learning spaces of participants. Fifty teachers $(28.7 \%)$ selected "not ever renovated to my knowledge", 14 (8.0\%) selected "more than 20 years ago", 41 (23.6\%) "20-10 years ago", and the majority of 69 teachers (39.7\%) replied "less than 10 years ago". The problem with this question is that repainting as part of routine maintenance might have been seen as a renovation, rather than the major structural changes that the question intended. However, 69 participants commented on Q4, of which 24 comments are not relevant or not clear. Twenty-one comments talked about the time building or renovating related to their learning environments happened. Teachers mentioned the exact year of renovations, such as "Finished 7 days ago" or "Renovated 
2 years ago". Twenty-four teachers commented on the type of renovation; 7 of them had been involved with conversions, such as a garage converted into a classroom, or two classrooms converted into one open plan space. The rest of the 24 comments about the type of renovation mentioned updates such as painting the walls, having new windows, new carpet, or having new furniture. In hindsight, this question would have been more useful had it been clearer about the types of renovation to the learning space.

The fifth question ( $Q 5, \mathrm{n}=174)$ is about the number of students in the current learning areas of teachers. Eleven teachers (6.3\%) had fewer than 20 students, 138 (79.3\%) had 20-30 students, and 25 teachers (14.4\%) had more than 30 students in their learning environments. There is no information in the guidelines provided by the Ministry about the standard number of students in each classroom with which to compare these results.

The sixth question $(\mathrm{Q} 6, \mathrm{n}=174)$ is about the number of fulltime teaching equivalents (FTE) in the learning area. One hundred twenty-two participating teachers $(70.1 \%)$ are teaching alone, $20(11.5 \%)$ are teaching with up to an additional 1 FTE, 10 (5.7\%) with 1-2 FTEs, 5 (2.9\%) with 2-3 FTEs, $11(6.3 \%)$ with more than 3 FTEs, and 6 teachers (3.4\%) selected "other" ( 4 of these stated they had teacher aides, but not how many FTEs these made, and 2 did not specify anything about FTEs). By correlating this question to Q5, in the 11 classrooms with fewer than 20 students, there are 6 
classrooms with only one teacher, 3 classrooms with up to 1 FTE besides the main teacher, and 1 classroom with 1-2 FTEs. This indicates that the majority of classrooms with fewer than 20 students have only one teacher. In the 139 classrooms with 20-30 students, there are 100 classrooms with one teacher, 15 classrooms with up to 1 FTE besides the main teacher, 6 classrooms with 1-2 FTEs, 4 classrooms with 2-3 FTEs, 5 classrooms with more than 3 FTEs, and 9 classrooms selected "other". This also indicates that the majority of classrooms with 20-30 students still have only one teacher. In the 25 classrooms with more than 30 students, there are 15 classrooms with one teacher, 2 classrooms with up to 1 FTE besides the main teacher, 2 classrooms with 1-2 FTEs, 1 classroom with 2-3 FTEs, 4 classrooms with more than 3 FTEs, and 1 classroom selected "other". Again, the majority of classrooms with more than 30 students have one teacher. So the number of students did not affect the number of adults working in the classrooms of teachers participating in the survey. This raises the issue of why a small number of classes have much more adult help than others, but this is an area for further research outside the scope of this thesis.

The last question $(\mathrm{Q} 7, \mathrm{n}=174)$ in this section is about the school year level of participants. One hundred twenty participant teachers $(69.0 \%)$ teach year 5/6, $15(8.6 \%)$ year 3-6, and 39 teachers $(22.4 \%)$ selected "other". Two of these did not specify the school year they are teaching, while the others explained that they are teaching in learning environments that include 
year 5 and/or year 6 , such as learning environments for years 6-8 or years 4-6.

\subsubsection{Discussion}

The responses to the previous questions indicate that the sample is representative of New Zealand primary schools. The lists of primary schools in New Zealand show that of 2036 primary schools, there are 1835 state schools (90.12\%), 134 integrated schools $(6.58 \%)$, and 67 private schools (3.29\%). These percentages are close to the responses of $93.7 \%$ state schools, $6.3 \%$ integrated schools, and $0 \%$ private schools.

The responses also indicate that the majority of learning environments are single-cell classrooms, which may suggest focusing on problems related to single-cell classrooms in order to find out if these single-cell classrooms can accommodate different furniture layout solutions, which might give better support to learning outcomes. There is no evidence that the existing classroom layouts from the surveys do not give satisfactory learning outcomes, although the literature does suggest this (see section 2.2.2), bearing in mind the average number of students in these classrooms.

\subsubsection{PARTiCipation IN THE DESIGN PROCESS}

In this section of 5 questions, participants were asked for information about their involvement in a past design process, such as who was responsible for choosing the furniture in the learning environment. 
The first question $(\mathrm{Q} 8, \mathrm{n}=174)$ is about whether they have worked in a school that has been renovated while they were there. Of the 174 participants who responded to this question, 105 (60.3\%) selected “yes" and 69 (39.7\%) "no". The second and third questions of this section only applied to those participants who selected "yes".

The second question $(\mathrm{Q} 9, \mathrm{n}=105)$ consists of 7 statements, and the participants had to select responses to a statement from a 5 point scale ranging from strongly agree (5) to strongly disagree (1). The statements and the mean responses are shown in Table 6-3. Most answers were effectively neutral, with two stronger agreements when it came to principals making design decisions and students not having the chance to talk to architects.

TAble 6-3: PARTicipant Responses to Q9 IN TEACHers' SURVey.

\begin{tabular}{|l|l|l|l|}
\hline Statement & $\begin{array}{l}\text { Number of } \\
\text { responses }\end{array}$ & Mean response & $\begin{array}{l}\text { Standard } \\
\text { deviation }\end{array}$ \\
\hline $\begin{array}{l}\text { I have been involved } \\
\text { in a design process } \\
\text { linked to renovations }\end{array}$ & 96 & 2.93 & 1.49 \\
\hline $\begin{array}{l}\text { I was asked to give my } \\
\text { opinion on a new } \\
\text { design for the } \\
\text { renovations }\end{array}$ & 96 & 3.20 & 1.46 \\
\hline $\begin{array}{l}\text { I was consulted } \\
\text { during the design }\end{array}$ & 96 & 2.70 & 1.30 \\
\hline
\end{tabular}




\begin{tabular}{|l|l|l|l|}
\hline Statement & $\begin{array}{l}\text { Number of } \\
\text { responses }\end{array}$ & Mean response & $\begin{array}{l}\text { Standard } \\
\text { deviation }\end{array}$ \\
\hline $\begin{array}{l}\text { process but my } \\
\text { opinion did not } \\
\text { change the design }\end{array}$ & 3.48 & 1.20 \\
\hline $\begin{array}{l}\text { The principal of the } \\
\text { school is the decision } \\
\text { maker in the design } \\
\text { process }\end{array}$ & 98 & 2.94 & 1.18 \\
\hline $\begin{array}{l}\text { The project manager is } \\
\text { the decision maker in } \\
\text { the design process }\end{array}$ & 96 & 3.28 & 1.43 \\
\hline $\begin{array}{l}\text { Teachers have no } \\
\text { chance to talk with } \\
\text { architects }\end{array}$ & 98 & 3.76 & 1.34 \\
\hline $\begin{array}{l}\text { Students have no } \\
\text { chance to talk with } \\
\text { architects }\end{array}$ & 98 & & \\
\hline
\end{tabular}

The third question $(\mathrm{Q} 10, \mathrm{n}=105)$ is about the party responsible for choosing certain items as part of the design of the learning environment. The parties are the architect, principal, teacher, students, Ministry of Education, and the project manager. Table 6-4 gives the sub-questions and the most chosen party for each statement. Participants could choose more than one party. 
TAble 6-4: PARTicipant Responses to Q10 in TeACHERS' SURVey.

\begin{tabular}{|c|c|c|c|c|}
\hline Sub-question & $\begin{array}{l}\text { Number of } \\
\text { respondents }\end{array}$ & $\begin{array}{l}\text { Number } \\
\text { of } \\
\text { responses }\end{array}$ & $\begin{array}{l}\text { Most chosen } \\
\text { party }\end{array}$ & $\begin{array}{l}\text { Least selected } \\
\text { party }\end{array}$ \\
\hline $\begin{array}{l}\text { Who chose the } \\
\text { furniture for } \\
\text { the classroom? }\end{array}$ & 100 & 147 & $\begin{array}{l}\text { The principal } \\
\text { (66 } \\
\text { responses) }\end{array}$ & $\begin{array}{l}\text { The Ministry of } \\
\text { Education and the } \\
\text { project manager } \\
\text { (5 responses) }\end{array}$ \\
\hline $\begin{array}{l}\text { Who chose the } \\
\text { colour (scheme } \\
\text { inside the } \\
\text { classroom? }\end{array}$ & 100 & 153 & $\begin{array}{l}\text { The principal } \\
(60 \\
\text { responses) }\end{array}$ & $\begin{array}{l}\text { The Ministry of } \\
\text { Education } \\
\text { ( } 2 \text { responses) }\end{array}$ \\
\hline $\begin{array}{l}\text { Who chose the } \\
\text { finishes of the } \\
\text { classroom? }\end{array}$ & 100 & 152 & $\begin{array}{l}\text { The principal } \\
\text { (65 } \\
\text { responses) }\end{array}$ & $\begin{array}{l}\text { The students } \\
\text { (2 responses) }\end{array}$ \\
\hline $\begin{array}{l}\text { Who chose the } \\
\text { location of the } \\
\text { fixtures (e.g., } \\
\text { sink/power } \\
\text { points) in the } \\
\text { classroom? }\end{array}$ & 100 & 152 & $\begin{array}{l}\text { The principal } \\
\text { and the } \\
\text { architect } \\
\text { (45 } \\
\text { responses) }\end{array}$ & $\begin{array}{l}\text { The students } \\
\text { (0 responses) }\end{array}$ \\
\hline
\end{tabular}

The fourth question (Q11, $\mathrm{n}=$ as shown in the table 6-5) is about the attention participating teachers give to school architecture. It consists of 6 statements, with participants selecting from a scale of strongly agree (5) to strongly disagree 
(1). Table 6-5 below shows the different statements and the mean responses to them.

Table 6-5: Participant Responses to Q11 IN TEachers' SURVeY.

\begin{tabular}{|l|l|l|l|}
\hline Statements & $\begin{array}{l}\text { Number of } \\
\text { responses }\end{array}$ & $\begin{array}{l}\text { Mean } \\
\text { response }\end{array}$ & $\begin{array}{l}\text { Standard } \\
\text { deviation }\end{array}$ \\
\hline $\begin{array}{l}\text { I often read about } \\
\text { school architecture } \\
\text { and design }\end{array}$ & 167 & 2.56 & 1.16 \\
\hline $\begin{array}{l}\text { I often integrate } \\
\text { what I have read } \\
\text { about school } \\
\text { architecture and } \\
\text { design in my } \\
\text { learning } \\
\text { environment }\end{array}$ & 161 & 2.66 & 1.18 \\
\hline $\begin{array}{l}\text { Learning to be a } \\
\text { teacher prepared } \\
\text { me for teaching in } \\
\text { traditional } \\
\text { classrooms. }\end{array}$ & 165 & 3.51 & 1.12 \\
\hline $\begin{array}{l}\text { Learning to be a } \\
\text { teacher prepared } \\
\text { me for teaching in } \\
\text { a variety of } \\
\text { learning } \\
\text { environments }\end{array}$ & 167 & 3.05 & 1.16 \\
\hline
\end{tabular}




\begin{tabular}{|c|c|c|c|}
\hline Statements & $\begin{array}{l}\text { Number of } \\
\text { responses }\end{array}$ & $\begin{array}{l}\text { Mean } \\
\text { response }\end{array}$ & $\begin{array}{l}\text { Standard } \\
\text { deviation }\end{array}$ \\
\hline $\begin{array}{l}\text { I have visited } \\
\text { other schools with } \\
\text { learning } \\
\text { environments } \\
\text { different from my } \\
\text { own }\end{array}$ & 163 & 4.14 & 0.97 \\
\hline $\begin{array}{l}\text { I have used things } \\
\text { I observed in visits } \\
\text { to different } \\
\text { learning } \\
\text { environments in } \\
\text { my own teaching } \\
\text { space }\end{array}$ & 161 & 4.05 & 0.91 \\
\hline
\end{tabular}

The last question $(\mathrm{Q} 12, \mathrm{n}=168)$ in this section is about checking the guidelines the Ministry of Education provide on their website. Of the 168 participants who responded to this question, 83 (49.4\%) $\quad$ selected "Never", 29 (17.3\%) "Occasionally", 4 (2.4\%) "Very Often", and 52 (31.0\%) of the participants were unaware of the Ministry guidelines, meaning effectively $80.4 \%$ never consulted these guidelines.

\subsubsection{DiscUSSION}

The majority of teachers in this survey work in a school that has been renovated while they have been teaching there. However, as most of their responses toward user participation in the design process are neutral and they have 
no strong voice in choosing the furniture and fixtures for the learning environments, the responses indicate that these teachers were probably not involved in the design process. In terms of student participation in the design process, the answers in this section show that students have such a small voice in this that it is as if they are not there. These results correspond with the information in the literature review. User involvement is very important to having successful designs (see section 3.1) and the participation of student users in designing learning environments is important for creating connections between students and their environments (see section 3.3).

\subsubsection{THE EXISTING LEARNING ENVIRONMENT}

This section consists of 5 questions about the existing learning environment of the participant teachers. The first question (Q13, $n=153)$ is about the different areas in the current learning space. Table 6-6 below shows the total percentage of area types that are present, from the most to the least selected area in the responses to the question.

TAble 6-6: PARTICIPANT ResPonses to Q13 IN TEACHERS' SURVey.

\begin{tabular}{|l|l|l|}
\hline Areas & Number of & $\begin{array}{l}\text { Percentage } \\
\text { based on the } \\
\text { responses } \\
\text { number of } \\
\text { respondents } \\
\mathbf{( 1 5 6 )}\end{array}$ \\
\hline Mat area & & $94.87 \%$ \\
\hline
\end{tabular}




\begin{tabular}{|c|c|c|}
\hline Areas & $\begin{array}{l}\text { Number of } \\
\text { responses }\end{array}$ & $\begin{array}{l}\text { Percentage } \\
\text { based on the } \\
\text { number of } \\
\text { respondents } \\
\text { (156) }\end{array}$ \\
\hline Shelves (including bookshelves) & 147 & $94.23 \%$ \\
\hline Desks/tables and chairs for all students & 140 & $89.74 \%$ \\
\hline Teacher's area & 129 & $82.69 \%$ \\
\hline Storage units & 125 & $80.13 \%$ \\
\hline Indoor/outdoor access & 117 & $75.00 \%$ \\
\hline Computer area (including any IT equipment) & 113 & $72.44 \%$ \\
\hline Group-work tables & 100 & $64.10 \%$ \\
\hline Art area & 96 & $61.54 \%$ \\
\hline Sofa/s & 60 & $38.46 \%$ \\
\hline $\begin{array}{l}\text { Some individual desks (not enough for all } \\
\text { students to sit down at the same time) }\end{array}$ & 38 & $24.36 \%$ \\
\hline Beanbags & 35 & $22.44 \%$ \\
\hline
\end{tabular}




\begin{tabular}{|l|l|l|}
\hline Areas & $\begin{array}{l}\text { Number of } \\
\text { responses }\end{array}$ & $\begin{array}{l}\text { Percentage } \\
\text { based on the } \\
\text { number of } \\
\text { respondents } \\
\mathbf{( 1 5 6 )}\end{array}$ \\
\hline Other & 22 & $14.10 \%$ \\
\hline $\begin{array}{l}\text { Music corner (area for music playing and } \\
\text { music instruments) }\end{array}$ & 8 & $4.13 \%$ \\
\hline Drama corner (area for drama items) & 2 & $1.28 \%$ \\
\hline
\end{tabular}

The second question (Q14, $\mathrm{n}=153$ ) is about how satisfied the teachers feel about the current furniture layout in their learning areas. Twelve teachers $(7.8 \%)$ were very dissatisfied, $18(11.8 \%)$ were dissatisfied, $34(22.2 \%)$ were somewhat dissatisfied, $22(14.4 \%)$ were neutral, 38 (24.8\%) were somewhat satisfied, 23 (15.0\%) were satisfied, and 6 (3.9\%) were very satisfied. The mean response, therefore, is neutral (3.97).

The third question $(\mathrm{Q} 15, \mathrm{n}=153)$ in this section is about the frequency of the participants making major changes to the furniture layout of the learning environment. Out of 153 responses to this question, $3(2.0 \%)$ selected "Never", 20 (13.1\%) “Once a year", 79 (51.6\%) “Once a term”, 49 (32.0\%) "More than once a term", and 2 (1.3\%) "Daily". A correlation between this question and Q14 is discussed in section 6.2.5. 
The fourth question (Q16, $\mathrm{n}=144 / 143)$ is about what influences the layout of a participant's learning environment. The participants were asked to rank 5 factors that might affect the layout, from the most influential factor to the least. Table 6-7 shows each factor and its mean and mode rank and Figure 62 shows a comparison of the different responses to the question.

TAble 6-7: PARTICIPANT RESPONSES to Q16 IN TEACHERS' SURVEY.

\begin{tabular}{|c|c|c|c|c|}
\hline Factor & $\begin{array}{l}\text { Number of } \\
\text { responses }\end{array}$ & Mean rank & $\begin{array}{l}\text { Standard } \\
\text { deviation }\end{array}$ & Mode rank \\
\hline $\begin{array}{l}\text { The number of } \\
\text { students }\end{array}$ & 143 & 2.20 & 1.45 & $\begin{array}{l}\text { Rank one } \\
69 \text { responses } \\
(48.25 \%)\end{array}$ \\
\hline $\begin{array}{l}\text { My teaching } \\
\text { style }\end{array}$ & 144 & 2.70 & 1.48 & $\begin{array}{l}\text { Rank one } \\
40 \text { responses } \\
(27.78 \%)\end{array}$ \\
\hline $\begin{array}{l}\text { The furniture } \\
\text { available }\end{array}$ & 145 & 2.77 & 1.34 & $\begin{array}{l}\text { Rank three } \\
38 \text { responses } \\
(26.21 \%)\end{array}$ \\
\hline $\begin{array}{l}\text { Location of } \\
\text { doors and } \\
\text { windows }\end{array}$ & 144 & 3.13 & 1.31 & $\begin{array}{l}\text { Rank three } \\
37 \text { responses } \\
(25.69 \%)\end{array}$ \\
\hline $\begin{array}{l}\text { Location of } \\
\text { room fixtures } \\
\text { (e.g., sink and } \\
\text { power points) }\end{array}$ & 144 & 3.30 & 1.41 & $\begin{array}{l}\text { Rank five } \\
38 \text { responses } \\
(26.39 \%)\end{array}$ \\
\hline
\end{tabular}




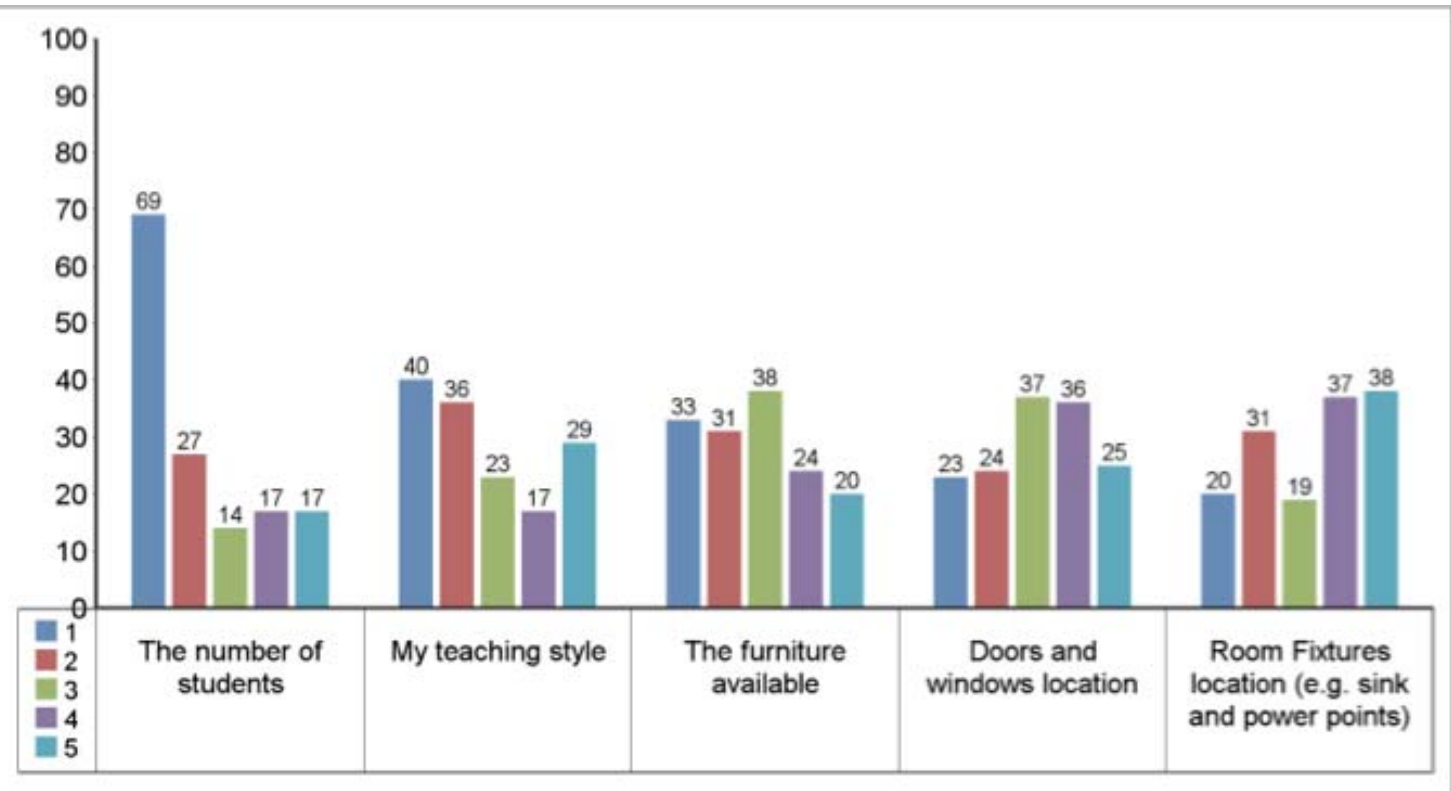

Figure 6-2: Participant Responses to $Q 16$ IN teachers' SURVEY.

Forty-four teachers commented on Q16, although 23 of the comments are neither clear nor relevant. Twelve of these are repetitions of factors mentioned in Q16. Some teachers explained why these factors are very important, for example, "My classroom is fairly small so I find I am limited to how I can arrange the furniture as well as what furniture is available", or "The number of students. If there are too many students then there isn't enough space to change the room much". Nine teachers added new factors that affect the layouts of their learning environments. These extra factors are listed below:

- Students' social abilities and personalities influence where furniture or groupings are placed (2 teachers)

- Having special-needs students (1 teacher)

- The school year or level (1 teacher) 
- The weather, as some schools may have connecting outside spaces used for learning activities with some furniture. So on bad weather days teachers need to take the furniture into the classroom to learn inside instead of outside (1 teacher).

- Location of the white board (1 teacher)

- Types and sizes of computers available in the classroom and location of the data projector in relation to the whiteboard (1 teacher)

- The daily activities completed in the classroom (2 teachers)

The last question $(Q 17, n=153 / 152)$ in this section is about the furniture layout and the involvement of students with this. It consists of 3 statements, and participants selected from a scale of strongly agree (5) to strongly disagree (1). Table 6-8 below shows the different statements and the mean response to them. The mode responses for these statements are the same as the mean responses.

TABle 6-8: PARTICIPANT RESPONSES TO Q17 IN TEACHERS' SURVEY.

\begin{tabular}{|l|l|l|l|}
\hline Statement & $\begin{array}{l}\text { Number of } \\
\text { responses }\end{array}$ & Mean response & $\begin{array}{l}\text { Standard } \\
\text { deviation }\end{array}$ \\
\hline $\begin{array}{l}\text { Students are } \\
\text { involved in the } \\
\text { classroom furniture } \\
\text { arrangement }\end{array}$ & 153 & 3.58 & 1.12 \\
\hline $\begin{array}{l}\text { The furniture } \\
\text { layout affects my } \\
\text { teaching style }\end{array}$ & 153 & 3.95 & 0.92 \\
\hline
\end{tabular}




\begin{tabular}{|l|l|l|l|}
\hline Statement & $\begin{array}{l}\text { Number of } \\
\text { responses }\end{array}$ & Mean response & $\begin{array}{l}\text { Standard } \\
\text { deviation }\end{array}$ \\
\hline $\begin{array}{l}\text { I have never } \\
\text { achieved my ideal } \\
\text { furniture layout in } \\
\text { my learning space }\end{array}$ & 152 & 3.67 & 1.15 \\
\hline
\end{tabular}

There is general agreement with all the statements, but this is strongest for the effect of internal layout on teaching style. This is an area for further research, which might be achieved through interviewing teachers about how the layout affects their teaching style.

\subsubsection{DISCUSSION}

In this section, the responses of teachers basically concerned the layout of their learning environments. The mode response for teacher satisfaction with their existing layouts is neutral. The majority of teachers change the furniture layout at least once a term. The things that most affect the learning environment layout are the number of students and personal teaching styles. Teachers have a mean response of agreement around never achieving their ideal furniture layout. These responses indicate that learning environments could be designed in better ways that allow teachers and students to maximize their learning activities inside these environments (see section 2.3).

Other things that emerged included the surprising lack of IT in over $25 \%$ of the schools of respondents, and although over 
$60 \%$ of respondents had access to an art area only $4 \%$ had a music corner (see table 2-7). In the light of the discussion of multiple intelligence (see chapter 1) this seems far from the provision of an ideal learning environment for primary aged children.

\subsubsection{IDEAL LAYOUTS AND DESIGN PROCESSES}

This section consists of 3 questions related to ideas and thoughts about future projects. The first question (Q18, n=141$144)$ is about actions that could improve the current furniture layout of the participants' learning spaces. The participants were asked to rank 6 actions linked to possible improvements, with 1 being the thing they most want and 6 the thing they least want to change. Table 6-9 shows each action and its mean and mode rank. Figure 6-2 shows a comparison of the different responses to the question.

TABle 6-9: PARTICIPANT ReSPONSES to Q18 IN TEACHERS' SURVEY.

\begin{tabular}{|l|l|l|l|l|}
\hline Action & $\begin{array}{l}\text { Number of } \\
\text { responses }\end{array}$ & $\begin{array}{l}\text { Mean } \\
\text { rank }\end{array}$ & $\begin{array}{l}\text { Standard } \\
\text { deviatio } \\
\mathbf{n}\end{array}$ & Mode rank \\
\hline $\begin{array}{l}\text { Get rid of some furniture } \\
\text { and not replace it }\end{array}$ & 142 & 4.08 & 1.63 & $\begin{array}{l}\text { Rank six } \\
37 \text { responses } \\
(26.06 \%)\end{array}$ \\
\hline $\begin{array}{l}\text { Replace some existing } \\
\text { with new furniture }\end{array}$ & 143 & 2.50 & 1.45 & $\begin{array}{l}\text { Rank one } \\
44 \text { responses } \\
(30.77 \%)\end{array}$ \\
\hline $\begin{array}{l}\text { Change the furniture } \\
\text { arrangement }\end{array}$ & 143 & 3.62 & 1.30 & Rank three \\
\hline
\end{tabular}




\begin{tabular}{|l|l|l|l|l|}
\hline Action & $\begin{array}{l}\text { Number of } \\
\text { responses }\end{array}$ & $\begin{array}{l}\text { Mean } \\
\text { rank }\end{array}$ & $\begin{array}{l}\text { Standard } \\
\text { deviatio } \\
\mathbf{n}\end{array}$ & Mode rank \\
\hline $\begin{array}{l}\text { Create more activity } \\
\text { corners (e.g., music } \\
\text { corner, art corner) }\end{array}$ & 144 & 3.08 & 1.54 & $\begin{array}{l}\text { Rank two } \\
40 \text { responses } \\
(27.78 \%)\end{array}$ \\
\hline $\begin{array}{l}\text { Request a bigger space } \\
(29.37 \%)\end{array}$ & 141 & 2.96 & 1.98 & $\begin{array}{l}\text { Rank one } \\
57 \text { responses } \\
(40.43 \%)\end{array}$ \\
\hline $\begin{array}{l}\text { Add indoor/outdoor } \\
\text { access }\end{array}$ & 143 & 4.50 & 1.56 & $\begin{array}{l}\text { Rank six } \\
54 \text { responses } \\
(37.76 \%)\end{array}$ \\
\hline
\end{tabular}




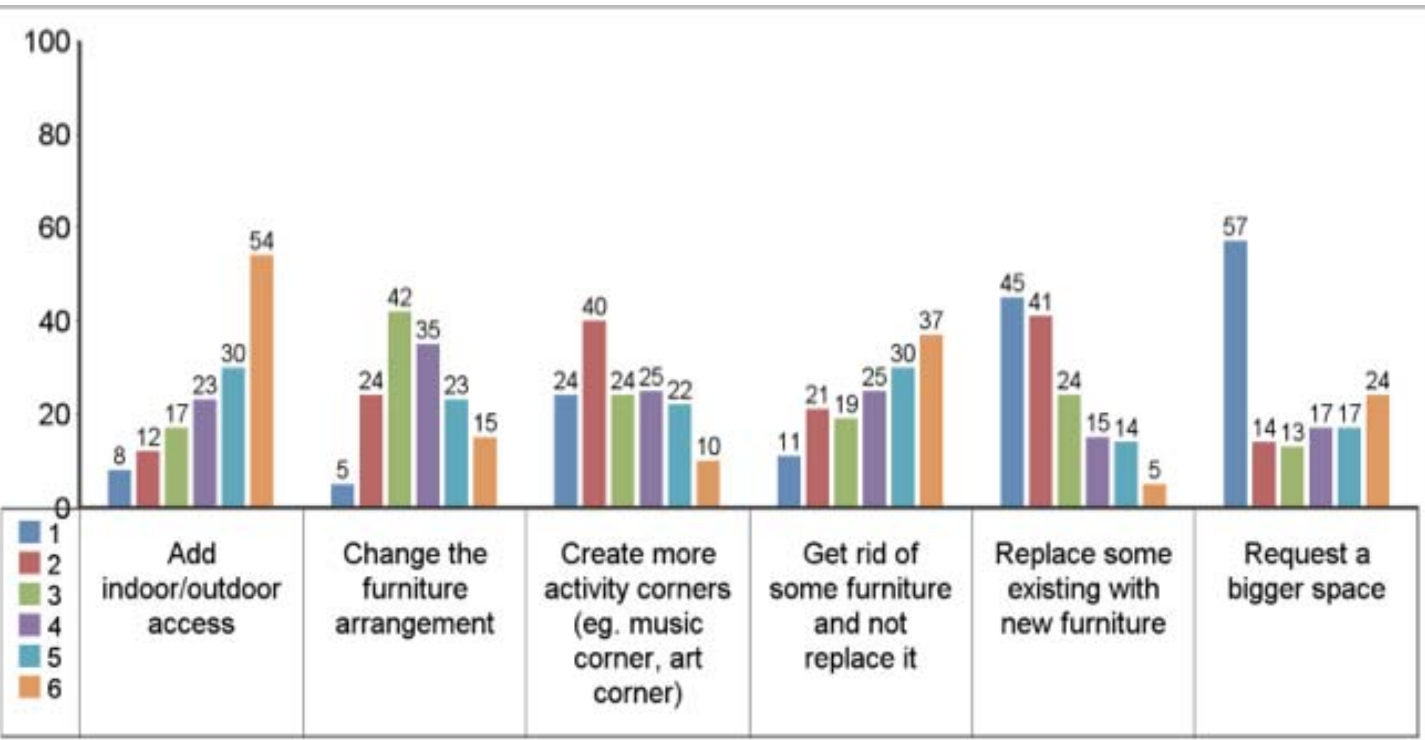

Figure 6-3: PARTICIPANT ReSPONSES to Q 18 IN TEACHERS'

SURVEY.

Thirty-nine participants commented on Q18 of which seventeen are not clear or relevant. Seven of the participants repeated some of the actions in Q18 in their comments, such as "Indoor/outdoor access is adequate" or "Appropriatesized chairs to meet the size of my students are a priority." Ten participants said that they had already made some of the changes or already had some of the things mentioned in Q18. For example, some teachers have already replaced old furniture with new or already have indoor/outdoor access. Five teachers suggested new things that could be changed or added to their classrooms. The suggestions were having more display area, building a loft for children for quiet reading and writing, having more laptops and computers, having a data projector or TV, and finally, having a recording studio and a 
creativity centre, as the teacher explains in the following quote:

I would like to add small recording studio spaces in my hub, as we are open plan, with doors that can close off suites. For kids to record (they do this quite often) they have to close off one whole suite, often only for a group of two or three kids not a good use of space. Having one or ideally several small spaces we could shut off easily with at least some soundproofing would be good. We are also in the process of creating one 'creativity' suit[e] where groups can go and work on art or creative projects away from the learning suites. I don't want these areas to be 'corners' in a classroom, but shared areas for other groups in the school to use, so we make the best use of the space we have.

The second question (Q19, $\mathrm{n}=144 / 142$ ) is about user participation in the design process. The participants were asked to rank 8 actions that they might want included in the design process, with 1 being the most important for them and 8 the least important. Table 6-10 below shows each action and its mean and mode rank. Figure 6-4 shows a comparison of the different responses to the question. Perhaps surprisingly, given that most participant teachers do not consult Ministry guidelines, having examples of good learning environments was most important for the teachers in this survey. 
TAble 6-10: PARTICIPANT ResPonses to Q19 IN TEACHERs' SURVEY.

\begin{tabular}{|l|l|l|l|l|}
\hline Action & $\begin{array}{l}\text { Total } \\
\text { number } \\
\text { of } \\
\text { responses }\end{array}$ & Mean rank & $\begin{array}{l}\text { Standard } \\
\text { deviation }\end{array}$ & Mode rank \\
\hline $\begin{array}{l}\text { I would like to be } \\
\text { asked about the type } \\
\text { of furniture my } \\
\text { learning } \\
\text { environment needs }\end{array}$ & 144 & 3.18 & 2.24 & $\begin{array}{l}\text { Rank one } \\
42 \text { responses } \\
(29.17 \%)\end{array}$ \\
\hline $\begin{array}{l}\text { I would like to be } \\
\text { asked about the best } \\
\text { location of the doors } \\
\text { and windows }\end{array}$ & 144 & 5.04 & 2.15 & $\begin{array}{l}\text { Rank five } \\
30 \text { responses } \\
(20.83 \%)\end{array}$ \\
\hline $\begin{array}{l}\text { I would like to be } \\
\text { asked about the } \\
\text { fixtures in my } \\
\text { learning } \\
\text { environment (e.g.r } \\
\text { sink, power points) }\end{array}$ & 144 & 4.61 & 2.06 & $\begin{array}{l}\text { Rank six } \\
26 \text { responses } \\
(18.06 \%)\end{array}$ \\
\hline $\begin{array}{l}\text { I would like to be } \\
\text { involved in the } \\
\text { selection of colours } \\
\text { and finishes for my } \\
\text { learning } \\
\text { environment }\end{array}$ & 144 & 5.06 & 2.26 & $\begin{array}{l}\text { Rank seven } \\
26 \text { responses } \\
(18.06 \%)\end{array}$ \\
\hline
\end{tabular}




\begin{tabular}{|l|l|l|l|l|}
\hline Action & $\begin{array}{l}\text { Total } \\
\text { number } \\
\text { of } \\
\text { responses }\end{array}$ & Mean rank & $\begin{array}{l}\text { Standard } \\
\text { deviation }\end{array}$ & Mode rank \\
\hline $\begin{array}{l}\text { I would like to be } \\
\text { consulted about the } \\
\text { size of my learning } \\
\text { environment }\end{array}$ & 144 & 3.59 & 2.41 & $\begin{array}{l}\text { Rank one } \\
38 \text { responses } \\
(26.39 \%)\end{array}$ \\
\hline $\begin{array}{l}\text { I would like to be } \\
\text { consulted about the } \\
\text { physical form of my } \\
\text { learning } \\
\text { environment (e.g., } \\
\text { open plan or single- } \\
\text { cell classroom) }\end{array}$ & 144 & 3.47 & 2.26 & $\begin{array}{l}\text { Rank one } \\
36 \text { responses } \\
(25.0 \%)\end{array}$ \\
\hline $\begin{array}{l}\text { I would like to be } \\
\text { provided with good } \\
\text { examples of learning } \\
\text { environments }\end{array}$ & 144 & 2.90 & 2.06 & $\begin{array}{l}\text { Rank one } \\
54 \text { responses } \\
(37.5 \%)\end{array}$ \\
\hline $\begin{array}{l}\text { I would like my } \\
\text { students to be } \\
\text { involved in the } \\
\text { design process }\end{array}$ & 142 & 4.32 & 2.39 & $\begin{array}{l}\text { Rank two } \\
26 \text { responses } \\
(18.31 \%)\end{array}$ \\
\hline
\end{tabular}




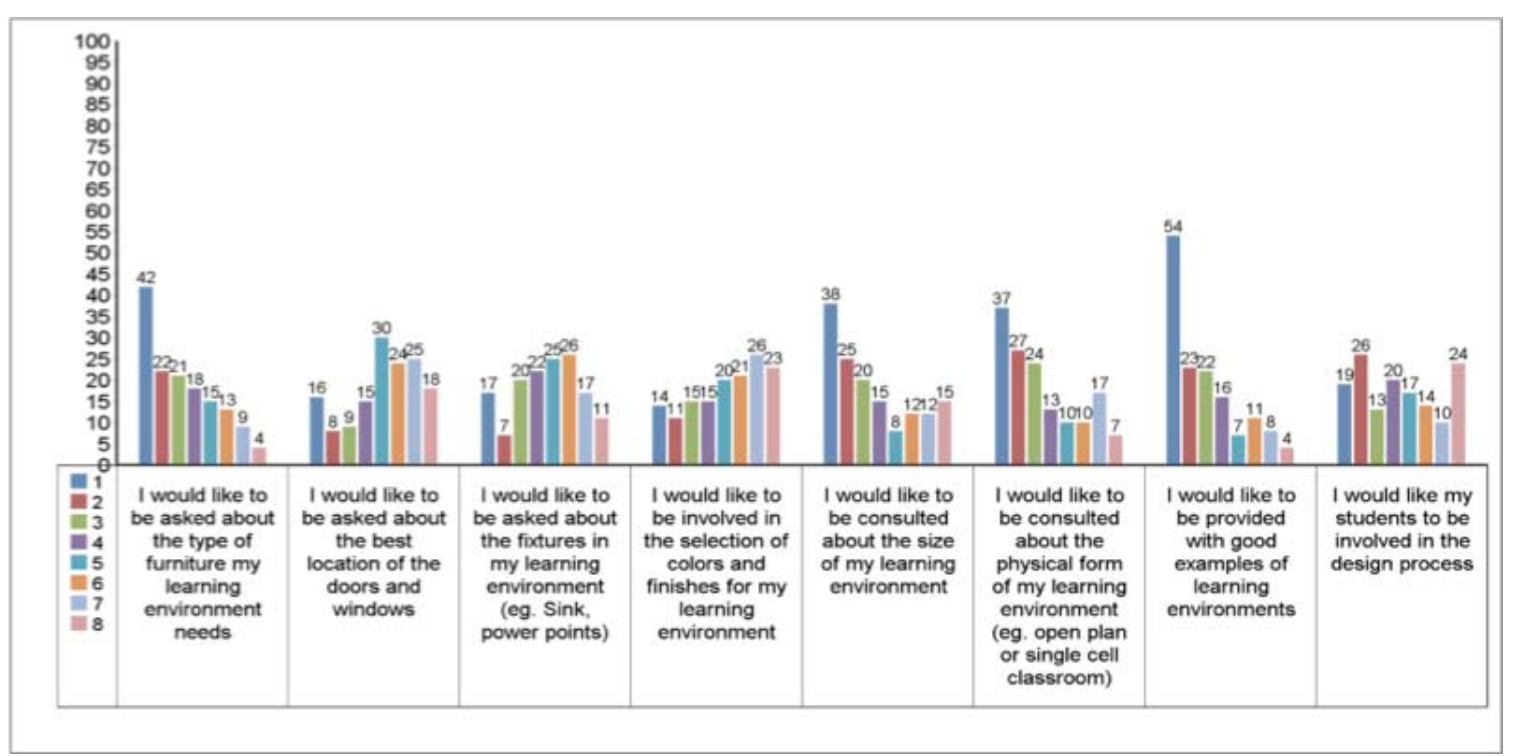

Figure 6-4: PaRTicipants Responses to Q20 IN TEACHeRs'

SURVEY.

Eighteen participants commented on Q19 with only 3 teachers having relevant comments. The first teacher felt that all the ways of involving teachers were important, but that teachers might not agree on one design. The second teacher said that they would like to be involved in selecting the type of windows and doors, as they know what is practical and safe for the students. The third teacher suggested that the whole process should be a collaborative work and include the students.

The last question (Q20, $\mathrm{n}=144 / 143)$ in this section is also about teacher and student participation in the design process. It consists of 2 statements, with the participants selecting from a scale of strongly agree (5) to strongly disagree (1). There is also a "not applicable" choice. Table 6-11 below shows the different statements and the mean responses to them. The mode responses for these statements are the same as the mean 
responses. Both answers indicate a wish for students and teachers to be involved in the design process, especially teachers.

TABle 6-11: PARTICIPANT RESPONSES TO Q20 IN TEACHERS' SURVEY.

\begin{tabular}{|l|l|l|l|}
\hline Statement & $\begin{array}{l}\text { Number } \\
\text { responses }\end{array}$ & Mean response & $\begin{array}{l}\text { Standard } \\
\text { deviation }\end{array}$ \\
\hline $\begin{array}{l}\text { Students should } \\
\text { be involved more } \\
\text { in the design }\end{array}$ & 144 & 3.99 & 0.84 \\
process & & 4.60 & \\
\hline $\begin{array}{l}\text { Teachers should } \\
\text { be involved more } \\
\text { in the design }\end{array}$ & 143 & & 0.56 \\
process & & & \\
\hline
\end{tabular}

\subsubsection{DISCUSSION}

This section gives a number of indicators for improving the design of future learning environments and could be of use for architects in helping them to focus on the needs of teachers. For example, in Q18 teachers ranked creating various activity corners within their learning environment as the second most important action for improving their existing learning environments. Given the lack of these, especially music corners (see section 6.1.2.3.1) this seems an area where design is not keeping pace with pedagogy. For teachers, the 
most important actions were changing the old furniture for new and having bigger spaces, the latter being something for the Ministry of Education to consider and not just architects. However, it might be possible to create spaces that feel bigger through the right use of the interior settings. Architects can think about specifying furniture that can stay in good condition for a long time and that can cope with different teaching styles as these change. In Q19, teachers indicated that they want to be involved in the design process. The architects can benefit from understanding the ways that teachers wish to be involved, such as providing them with good examples of learning environments, which was another important factor for teachers, consulting them about the size of the learning environment, and asking them about the type of furniture the learning environment needs.

The last thing in this section and the most important issue in terms of this study is that teachers agree that they and their students need to be involved more in the design process of learning environments.

\subsubsection{CORRELAtions IN THE TEACHERS' SURVEY}

In this section, 5 correlations are discussed. All are related to participant responses concerning teachers and students being more involved in the design process (see Table 6-11).

The first is to find out the connection between teachers who have been involved in educational design projects and their responses to involving students in the design process. Teachers who have been involved in the design process of 
renovations (84 responses) have a mean response of 4.07 for agreeing students should be more involved in the design process and 4.57 for teachers being more involved, compared to 3.99 , the mean response from all participants towards student involvement, and 4.60 for teacher involvement. These results suggest that all teachers have a similar view of student and teacher involvement, whatever their prior experience of being involved in changes and renovations to their schools.

The second correlation concerns the responses of teachers who have not been involved in any educational design or renovation project. There were 61 responses from such teachers, with mean responses of 3.85 for more student involvement in the design process and 4.66 for more teacher involvement. These means indicate that they also had a similar response to both the whole sample and the sample of teachers who had been involved in a school design project.

The third correlation deals with responses from people who change their classroom layout. Table 6-22 and Figure 6-5 show the different responses according to how frequently teachers change their classroom internal layouts. 
TABLE 6-12: RESPONSES FROM PEOPLE WHO CHANGE THEIR

CLASSROOM LAYOUT TO TEACHER AND STUDENT INVOLVEMENT IN

THE DESIGN PROCESS.

\begin{tabular}{|l|c|c|}
\hline $\begin{array}{l}\text { The frequency of changing } \\
\text { the classroom layout }\end{array}$ & $\begin{array}{c}\text { Involving } \\
\text { students }\end{array}$ & \begin{tabular}{l} 
Involving teachers \\
\hline Never
\end{tabular} \\
\hline Once a year & 3.50 & 4.50 \\
\hline Once a term & 3.92 & 4.64 \\
\hline More than once a term & 4.09 & 4.69 \\
\hline Daily & 4.50 & 4.50 \\
\hline All participants & 3.99 & 4.60 \\
\hline
\end{tabular}

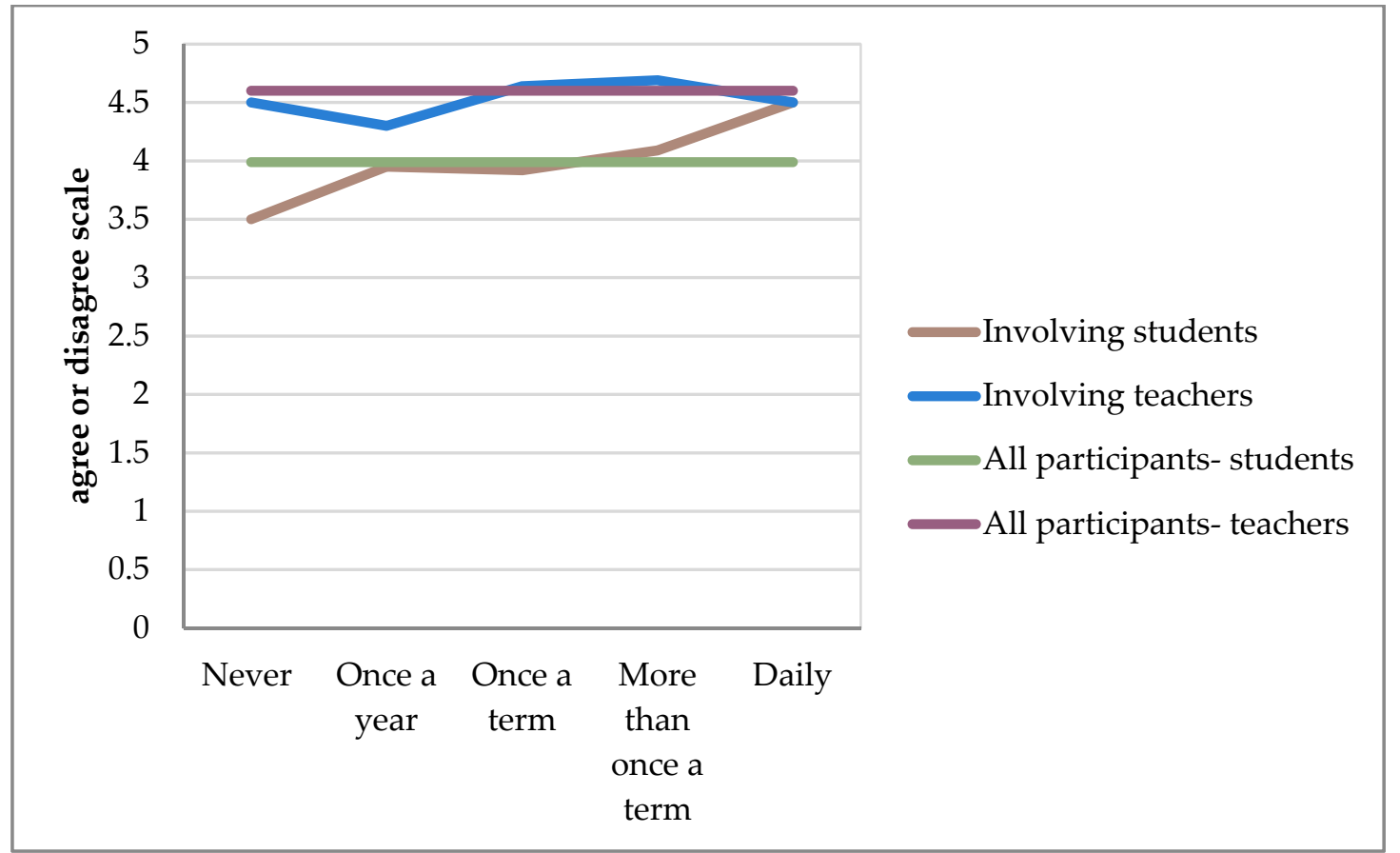

FIGURE 6-5: COMPARISON OF RESPONSES TO TEACHER AND STUDENT INVOLVEMENT FROM ALL PARTICIPANTS AND TEACHERS WHO CHANGE THEIR LEARNING ENVIRONMENT LAYOUTS. 
It is noticeable that, in terms of student involvement, teachers who change their classroom layouts more are keener to involve students in the design process, whereas in terms of teacher involvement in the design process, there is no pattern that connects the responses to the frequency of changing the classroom layout.

The fourth correlation concerns all teachers who checked the Ministry of Education guidelines, whether occasionally or very often, especially given the Ministry does promote a more collaborative design process (see section 4.2.2) and user involvement in the design process. Of those who checked the guidelines mean responses (146 responses) are 3.98 for students being more involved in the design process and 4.60 for teacher involvement, which are almost the same as the mean responses for the whole sample.

The final correlation concerns teachers who agreed or strongly agreed that they involve students in changing the internal layout and their responses to encouraging more student involvement in the design process. The mean response of these teachers toward involving students in the design process (95 responses) is 4.19 , which is slightly higher than for all participants but still gives the same result, which is "Agree".

Overall, it seems that teachers who are active in changing their learning environment layouts are slightly more in favour of a collaborative design process, although this is something that is supported by all teachers in the survey. However, it 
does suggest that involving student users in design is seen positively by teachers who do this.

\subsection{ARCHITECTS' SURVEY RESULTS}

In June 2013 the architects' survey was sent to 60 architects throughout New Zealand. Thirty people started the questionnaire but only 12 completed it. All of those who did not complete stopped before answering any of the questions. This gave a low $20 \%$ response rate and means the results are only indicative and not statistically significant.

\subsubsection{General QUESTIONS}

The first section concerned general information about the practice of each architect, and 12 participants responded to this section.

The first question $(\mathrm{Q} 1, \mathrm{n}=12)$ concerns the average number of staff working in the architects' offices. Five participants (41.67\%) have 1-6 staff members, while 7 (58.33\%) have 6-20 staff members. No-one has more than 20 staff members in their offices.

The second question $(\mathrm{Q} 2, \mathrm{n}=12)$ is when the participant's last educational (school) project happened. Ten (83.33\%) are currently working on a project, 1 participant $(8.33 \%)$ completed their last educational project 1-5 years ago, and 1 $(8.33 \%)$ more than 10 years ago. No participants had completed educational projects 5-10 years ago.

The third question $(\mathrm{Q} 3, \mathrm{n}=12)$ is about the number of primary school projects completed by the participants. Three $(25.0 \%)$ 
have completed 2-5 projects while $9(75.0 \%)$ have completed more than 5 projects.

In comments about this section, the architects elaborated on their experience on working on educational projects. Three of the architects mentioned that they had worked on $60-120$ educational projects during their careers.

\subsubsection{Discussion}

The majority of respondents to the architects' survey have completed at least 6 primary school projects, so although the number of participants is low, the participants have good experience of working on primary school projects and their responses in this survey should thus reflect a good knowledge of the subject.

\subsubsection{DeSIGNING SCHOOLS}

This section contained 3 questions about designing schools. The first (Q4, n=12) was about involving users in designing schools and consisted of 2 statements, with participants selecting from a scale of strongly agree (5) to strongly disagree (1). Table 6-13 shows the different statements and the mean responses to them.

TABle 6-13: PARTICIPANTS RESPONSES TO Q4 IN ARCHiteCtS' SURVEY.

\begin{tabular}{|l|l|l|l|}
\hline Statement & $\begin{array}{l}\text { Total number } \\
\text { of responses }\end{array}$ & Mean response & $\begin{array}{l}\text { Standard } \\
\text { deviation }\end{array}$ \\
\hline
\end{tabular}




\begin{tabular}{|l|l|l|l|}
\hline $\begin{array}{l}\text { Working with } \\
\text { teachers improves } \\
\text { the quality of school } \\
\text { design }\end{array}$ & 12 & 4.25 & 0.62 \\
\hline $\begin{array}{l}\text { Working with } \\
\text { children improves } \\
\text { the quality of school } \\
\text { design }\end{array}$ & 12 & 3.58 & 0.67 \\
\hline
\end{tabular}

The second question $(\mathrm{Q} 5, \mathrm{n}=12)$, which consisted of $5 \mathrm{sub}$ questions, was about the number of layouts tried for each school area. The choices they had were None, Only one layout, More than one layout, or not applicable. Table 6-14 below shows the sub-questions and the mode response to each. 
TAble 6-14: PARTicipants' Responses to Q5 IN ARChItects' SURVEY.

\begin{tabular}{|c|c|}
\hline Sub-question & $\begin{array}{l}\text { Mode response } \\
\text { Number of } \\
\text { responses }\end{array}$ \\
\hline $\begin{array}{l}\text { When designing a primary school foyer } \\
\text { (reception), typically how many different furniture } \\
\text { layouts do you try? }\end{array}$ & $\begin{array}{l}\text { More than one } \\
\text { layout }(100 \%) \\
12 \text { responses }\end{array}$ \\
\hline $\begin{array}{l}\text { When designing a primary school library, typically how } \\
\text { many different furniture layouts do you try? }\end{array}$ & $\begin{array}{l}\text { More than one } \\
\text { layout }(83.33 \%) \\
10 \text { responses }\end{array}$ \\
\hline $\begin{array}{l}\text { When designing a primary school hall, typically how } \\
\text { many different furniture layouts do you try? }\end{array}$ & $\begin{array}{l}\text { More than one } \\
\text { layout }(91.67 \%) \\
11 \text { responses }\end{array}$ \\
\hline $\begin{array}{l}\text { When designing a primary school office, typically how } \\
\text { many different furniture layouts do you try? }\end{array}$ & $\begin{array}{l}\text { More than one } \\
\text { layout }(91.67 \%) \\
11 \text { responses }\end{array}$ \\
\hline $\begin{array}{l}\text { When designing a primary school outdoor area, typically } \\
\text { how many different furniture layouts do you try? }\end{array}$ & $\begin{array}{l}\text { More than one } \\
\text { layout }(100 \%) \\
12 \text { responses }\end{array}$ \\
\hline
\end{tabular}

The third question (Q6, $\mathrm{n}=12$ ) was about which party is responsible for choosing certain items in school projects. 
There are 3 sub-questions and the parties involved are the architect, principal, teacher, students, Ministry of Education, and the project manager. Table 6-15 gives the sub-questions and the mode for each statement.

TABle 6-15: PARTICIPANTS' RESPONSES TO Q6 IN ARCHITECTS' SURVEY.

\begin{tabular}{|l|l|l|l|l|}
\hline Sub-question & $\begin{array}{l}\text { Total } \\
\text { number of } \\
\text { respondents }\end{array}$ & $\begin{array}{l}\text { Total } \\
\text { number } \\
\text { of } \\
\text { responses }\end{array}$ & $\begin{array}{l}\text { Most selected } \\
\text { party }\end{array}$ & $\begin{array}{l}\text { Least selected } \\
\text { party }\end{array}$ \\
\hline $\begin{array}{l}\text { Who chooses } \\
\text { the furniture } \\
\text { for the school? }\end{array}$ & 12 & 24 & $\begin{array}{l}\text { The principal } \\
\text { (9 responses })\end{array}$ & $\begin{array}{l}\text { The students } \\
\text { (0 responses })\end{array}$ \\
\hline $\begin{array}{l}\text { Who chooses } \\
\text { the colour- } \\
\text { scheme inside } \\
\text { the school? }\end{array}$ & 12 & 21 & $\begin{array}{l}\text { The architect } \\
(10 \text { responses })\end{array}$ & $\begin{array}{l}\text { The students, } \\
\text { Thinistry } \\
\text { of Education, } \\
\text { and the project }\end{array}$ \\
\hline $\begin{array}{l}\text { Who chooses } \\
\text { the finishes of } \\
\text { the school? }\end{array}$ & 12 & 18 & $\begin{array}{l}\text { The architect } \\
(12 \text { responses })\end{array}$ & $\begin{array}{l}\text { The students } \\
(0 \text { responses })\end{array}$ \\
\hline
\end{tabular}

In the comments about this section, architects discussed issues related to involving users in the design process. One architect said that their job is to introduce the new ideas to teachers, not to take ideas from teachers and what teachers are 
used to. Three architects discussed problems with involving users, including the fact that teachers struggle when working with a blank canvas, as they are used to working with what they are given. This means that some teachers may drag the design back to a 1960s school design. Additionally, they felt students and some teachers have limited spatial experience. However, one architect said that it is interesting to observe how teachers and students use their current spaces.

\subsubsection{DISCUSSION}

Although the mode response from participants indicates that they agree that working with teachers and students improves the quality of school designs, most if not all say that architects or the school principal are responsible for choosing the basic elements inside the learning environments, such as the furniture and finishes. This may indicate that architects are keen to receive some ideas and thoughts from users but still think that these users are not capable of making decisions. It may also be a reflection of the fact that architects feel that the time of teachers and their students is limited and so they cannot be involved in all the decisions related to the design process.

\subsubsection{Designing Classrooms}

This section consisted of 3 questions about designing classrooms. The first $(\mathrm{Q} 7, \mathrm{n}=12)$ was about involving users in design and consisted of 2 statements, with the participants selecting from a scale of agree (5) to disagree (1). Table 6.16 
shows the different statements and the mean response to them.

TABle 6-16: PARTICIPANT RESPONSES TO Q7 IN ARChITECTS' SURVEY.

\begin{tabular}{|l|l|l|l|}
\hline Statement & $\begin{array}{l}\text { Total number } \\
\text { of responses }\end{array}$ & Mean response & $\begin{array}{l}\text { Standard } \\
\text { deviation }\end{array}$ \\
\hline $\begin{array}{l}\text { Working with teachers } \\
\text { improves the quality } \\
\text { of classroom design }\end{array}$ & 12 & 3.92 & 0.79 \\
\hline $\begin{array}{l}\text { Working with children } \\
\text { improves the quality } \\
\text { of classroom design }\end{array}$ & 12 & 3.42 & 0.67 \\
\hline
\end{tabular}

The second question (Q8, $\mathrm{n}=12$ ) was about the number of layouts tried for each classroom design. One participant $(8.33 \%)$ chose "none", one participant $(8.33 \%)$ "Only one layout" and 10 participants (83.33\%) "More than one layout". The third question (Q9, $\mathrm{n}=12)$ was about which party is responsible for choosing certain items in classroom designs. There were 3 sub-questions, and the parties were the architect, principal, teacher, students, Ministry of Education, and the project manager. Table 6-17 sets out the sub-questions and the mode for each statement. 
TABle 6-17: PARTICIPANT ResPonses to Q9 IN ARChITECTS' SURVEY.

\begin{tabular}{|c|c|c|c|c|}
\hline Sub-question & $\begin{array}{l}\text { Total } \\
\text { number of } \\
\text { respondents }\end{array}$ & $\begin{array}{l}\text { Total } \\
\text { number } \\
\text { of } \\
\text { responses }\end{array}$ & The mode & $\begin{array}{l}\text { The least } \\
\text { selected party }\end{array}$ \\
\hline $\begin{array}{l}\text { Who chose the } \\
\text { furniture for } \\
\text { the classroom? }\end{array}$ & 12 & 23 & $\begin{array}{l}\text { The principal } \\
\text { (11 responses) }\end{array}$ & $\begin{array}{l}\text { The students } \\
\text { (0 responses) }\end{array}$ \\
\hline $\begin{array}{l}\text { Who chose the } \\
\text { colour-scheme } \\
\text { inside the } \\
\text { classroom? }\end{array}$ & 12 & 21 & $\begin{array}{l}\text { The architect } \\
\text { (9 responses) }\end{array}$ & $\begin{array}{l}\text { The students, } \\
\text { The Ministry of } \\
\text { Education, and } \\
\text { the project } \\
\text { manager } \\
\text { (0 responses) }\end{array}$ \\
\hline $\begin{array}{l}\text { Who chose the } \\
\text { finishes of the } \\
\text { classroom? }\end{array}$ & 12 & 19 & $\begin{array}{l}\text { The architect } \\
\text { (12 responses) }\end{array}$ & $\begin{array}{l}\text { The students } \\
\text { (0 responses) }\end{array}$ \\
\hline
\end{tabular}

The architects' comments fell into in two categories. In the first, they discussed how the school's Board of Trustees (BoT) are sometimes involved in selecting the furniture and that the involvement of teachers and students depends on how detailed the principal and BoT want such possible involvement to be. The second category concerned the fact that the project budget provided by the Ministry to architects does not include the furniture. Thus, the architects cannot be 
involved in selecting furniture unless the principal and BoT consult them.

\subsubsection{Discussion}

The architects agreed that working with teachers improves the design of classrooms, while they neither agreed nor disagreed that working with children would have the same outcome. In comparing these responses to those in the previous section about involving students and teachers in designing schools, architects were more positive in terms of involving students in designing schools than in designing classrooms. This is a little odd, as students spend most of their school day inside the classroom, using its facilities. Perhaps architects feel that the classroom environment has more to do with the selection of its furniture than with the design of its envelope, given they have control over the latter but not the former.

In terms of who is responsible for selecting colours, furniture, and finishes of the classroom, the responses were the same as those for who is responsible for selecting colours, furniture, and finishes for the school. This suggests that classroom design is seen as part of school design, using the same strategies and methods.

\subsubsection{DESIGN PROCESS IN GENERAL}

This section contained 3 general questions about the design process and the difficulties that might occur when designing learning environments. The first question $(\mathrm{Q} 10, \mathrm{n}=12)$ was about user participation in the design process and consisted 
of 8 statements, with participants selecting from a scale of agree (5) to disagree (1). There was also a "not applicable" choice. Table 6-18 shows the different statements and the mean response to them.

TAble 6-18: PARTICIPANT ReSPONSES TO Q10 in ARCHITECTS' SURVEY.

\begin{tabular}{|l|l|l|l|}
\hline Statement & $\begin{array}{l}\text { Number } \\
\text { responses }\end{array}$ & Mean response & $\begin{array}{l}\text { Standard } \\
\text { deviation }\end{array}$ \\
\hline $\begin{array}{l}\text { The principal of the } \\
\text { school is the } \\
\text { decision maker in } \\
\text { the design process }\end{array}$ & 12 & 0.8 & \\
\hline $\begin{array}{l}\text { The project } \\
\text { manager is the } \\
\text { decision maker in } \\
\text { the design process }\end{array}$ & 10 & 2.70 & 1.05 \\
\hline $\begin{array}{l}\text { Architects have no } \\
\text { chance to talk with } \\
\text { teachers }\end{array}$ & 12 & 1.92 & 0.87 \\
\hline $\begin{array}{l}\text { Architects have no } \\
\text { chance to talk with } \\
\text { students }\end{array}$ & 12 & 2.25 & 0.75 \\
\hline $\begin{array}{l}\text { Schools reject new } \\
\text { architects }\end{array}$ & 12 & 25 & \\
\hline
\end{tabular}




\begin{tabular}{|l|l|l|l|}
\hline Statement & $\begin{array}{l}\text { Number of } \\
\text { responses }\end{array}$ & Mean response & $\begin{array}{l}\text { Standard } \\
\text { deviation }\end{array}$ \\
\hline $\begin{array}{l}\text { Teachers should be } \\
\text { involved more in } \\
\text { the design process }\end{array}$ & 12 & 3.75 & 0.62 \\
\hline $\begin{array}{l}\text { Children should be } \\
\text { involved more in } \\
\text { the design process }\end{array}$ & 12 & 3.08 & 0.67 \\
\hline $\begin{array}{l}\text { The current } \\
\text { structure of the } \\
\text { design process for } \\
\text { schools is totally } \\
\text { satisfactory }\end{array}$ & 11 & 2.82 & 0.60 \\
\hline
\end{tabular}

The second question (Q11, n=12) was about the difficulties architects might face during the process of designing a school. Table 6-19 sets these out from the most selected to the least selected difficulty.

TAble 6-19: Participants Responses to Q11 IN ARChitects' SURVEY.

\begin{tabular}{|l|l|l|}
\hline $\begin{array}{l}\text { Difficulties architects might face during the } \\
\text { process of designing a school }\end{array}$ & $\begin{array}{l}\text { The number } \\
\text { of responses } \\
\text { to a certain } \\
\text { setting }\end{array}$ & $\begin{array}{l}\text { Percentage } \\
\text { based on the } \\
\text { number of } \\
\text { respondents } \\
\mathbf{( 1 2 )}\end{array}$ \\
\hline Lack of money in the budget & 12 & $100 \%$ \\
\hline
\end{tabular}




\begin{tabular}{|l|l|l|}
\hline $\begin{array}{l}\text { Difficulties architects might face during the } \\
\text { process of designing a school }\end{array}$ & $\begin{array}{l}\text { The number } \\
\text { of responses } \\
\text { to a certain } \\
\text { setting }\end{array}$ & $\begin{array}{l}\text { Percentage } \\
\text { based on the } \\
\text { number of } \\
\text { respondents } \\
\mathbf{( 1 2 )}\end{array}$ \\
\hline Dealing with the Ministry of Education & 7 & $58.33 \%$ \\
\hline Communicating with users & 5 & $41.67 \%$ \\
\hline Lack of time to do research & 5 & $41.67 \%$ \\
\hline $\begin{array}{l}\text { Teachers or principals do not know much } \\
\text { about architecture }\end{array}$ & 4 & $33.33 \%$ \\
\hline Lack of good school prototypes in New & 2 & \\
\hline Zealand & & $00.00 \%$ \\
\hline Other & 1 & \\
\hline Lack of access to design resources & & \\
\hline
\end{tabular}

The third question (Q12, n=11), "How would you modify the current design process?" is an open-ended question. Participants put forward 18 suggestions for how the current design process could be modified. Seven out of the 18 are in favour of increasing the budget, such as "Budget for fees and buildings is a problem; particularly, the procurement of services on a lowest cost is best. Schools are being significantly short changed 
by this approach". Four suggestions talked about time limitations for finishing a project for learning environments. They claim that time is very limited for the size of school projects. One of the architects said, "Timeframes are often inadequate". Six suggestions discussed communications between architects and learning environment users and indicated that there is a need for more connection between architects and teachers and students, e.g., "spending time with staff and students". One suggestion is about having collaborative work between all the parties involved in the design process. The architect said, "By increasing the collaborative approach in design. Dealing with three different schools as both the project manager/architect, there are three different ways of carrying out the work, as determined by the BoT (board of trustees) and Principals of each school, and their expertise. Having some form of continuity would be good. When all are working together, then good design happens."

Architects often linked time limitations with budget limitations, for example, "Spend more time researching and hopefully have enough fees to warrant this time spent."

The comments in this section claim that involving users in the design process is very important. However, architects said that some teachers might suggest ideas that benefit them individually without thinking about the whole school. They also said that teachers might suggest ideas that may not be suitable for other teachers who might work in the same space in the future. 


\subsubsection{DiscUSSION}

The participants agree that the principal is the decision maker and they also claim that they have the chance to talk with both teachers and students during the design process. These responses indicate that although principals decide many things in the design, architects still communicate with teachers and students, or at least they say that they do this. However, it is not clear from the answers how this conversation is organized, or how the results are recorded and used in the school design. This suggests the architects may think the idea is one they should think is good but which they might not necessarily use in their projects.

Another noticeable issue in this section is the architects' responses towards having more user involvement. While the architects are positive towards more teacher involvement in the design process, they neither agree nor disagree on having more student involvement, suggesting they might think it is easier to work with adults than children, not least because there is only 1 teacher in a class of maybe 30 children. However, substantiating this would require further research.

The third issue in this section is that although the main difficulty faced by the architects is dealing with a limited budget, they did think about problems with communication in the design process. This indicates that architects may want to work with children and teachers when it comes to design but prefer to spend their limited time and budget on more important things (in their opinion), such as communication 
with the principal and collecting background data for the project.

\subsubsection{Ministry of EducAtion}

This section contained 3 questions about the guidelines provided by the Ministry of Education. The first (Q13, $n=12)$ is about the frequency of checking the Ministry's guidelines. One participant (8.33\%) selected "Never", 2 (16.67\%) “Occasionally," 4 (33.33\%) "Fairly often," 2 (16.67\%) “Very often," and 3 (25.0\%) "For every school project." The mean response was "Fairly often" (3.33).

The second question $(\mathrm{Q} 14, \mathrm{n}=11)$ was asked of all participants except those selecting "never" in the previous question. This question is about satisfaction with the Ministry guidelines. One participant (9.99\%) selected "Very dissatisfied", 1 participant (9.99\%) "Somewhat dissatisfied," 5 participants (45.45\%) “Neutral," and 4 participants (36.36\%) "Somewhat Satisfied." No participants selected "Dissatisfied", "Satisfied", or "Very Satisfied". The mean response was "Neutral" (4.00).

The third question (Q15, n=9) was "How could the guidelines be improved?" Overall, respondents suggested 5 specific ideas to improve the Ministry's guidelines. Of these, 2 were about having more examples in the guidelines, and 2 were about discussing the budget. One idea was about adding more spatial arrangements. Five ideas were offered about the guidelines themselves, including whether or not there should be guidelines, as they can restrict new ideas, or that the 
guidelines are out of date and need to be more flexible about incorporating new ideas and more details. For example, one architect said, "From an architect's point of view, the best situation would be to remove all guidelines as they can restrict new ideas and methods, but I can see that this would cause some disasters and the MOE don't want to take that risk with public money and no control."

\subsubsection{Discussion}

The responses in this section show that the Ministry may need to work on its guidelines regarding the design process, and the architects' comments could help the Ministry in improving these.

\subsubsection{Post-Occupancy Evaluation}

This section contained 2 questions about post-occupancy evaluation. The first $(\mathrm{Q} 16, \mathrm{n}=12)$ concerned whether participants conduct post-occupancy evaluations of their primary school work. Ten architects (83.33\%) said "yes, but not formal" while the other $2(16.67 \%)$ indicated "not at all". No participant selected "yes, formal evaluations".

The second question $(\mathrm{Q} 17, \mathrm{n}=8)$ was asked of participants answering "yes, formal evaluations" or "yes, but not formal". The question was about the things participants observe that help them most in their new projects. Participants were asked to rank 8 things, from the most observed thing that helped them to the least. Table 6-20 and Figure 6-6 show each thing and its mean and mode rank. 
TAble 6-20: PARTICIPANT Responses to Q17 IN ARChitects' SURVEY.

\begin{tabular}{|c|c|c|c|}
\hline Observed item & $\begin{array}{l}\text { Total number } \\
\text { of responses }\end{array}$ & Mean rank & Mode rank \\
\hline Window treatments & 8 & 6.5 & $\begin{array}{l}\text { Rank eight } \\
4 \text { responses }(50 \%)\end{array}$ \\
\hline Classroom finishes & 8 & 3.38 & $\begin{array}{l}\text { Rank one } \\
3 \text { responses }(37.5 \%)\end{array}$ \\
\hline Classroom colours & 8 & 4.88 & $\begin{array}{l}\text { Rank four } \\
3 \text { responses }(37.5 \%)\end{array}$ \\
\hline $\begin{array}{l}\text { Classroom } \\
\text { furniture layouts }\end{array}$ & 8 & 3.38 & $\begin{array}{l}\text { Rank one and five } \\
2 \text { responses }(25 \%)\end{array}$ \\
\hline $\begin{array}{l}\text { Office area } \\
\text { furniture layouts }\end{array}$ & 8 & 5.13 & $\begin{array}{l}\text { Rank four and five } \\
2 \text { responses }(25 \%)\end{array}$ \\
\hline $\begin{array}{l}\text { School hall } \\
\text { furniture layouts }\end{array}$ & 8 & 6.88 & $\begin{array}{l}\text { Rank six and seven } \\
3 \text { responses }(37.5 \%)\end{array}$ \\
\hline Noise control & 8 & 2.38 & $\begin{array}{l}\text { Rank two } \\
4 \text { responses }(50 \%)\end{array}$ \\
\hline $\begin{array}{l}\text { Temperature } \\
\text { control }\end{array}$ & 8 & 3.5 & $\begin{array}{l}\text { Rank one, three } \\
\text { and seven } \\
2 \text { responses }(25 \%)\end{array}$ \\
\hline
\end{tabular}




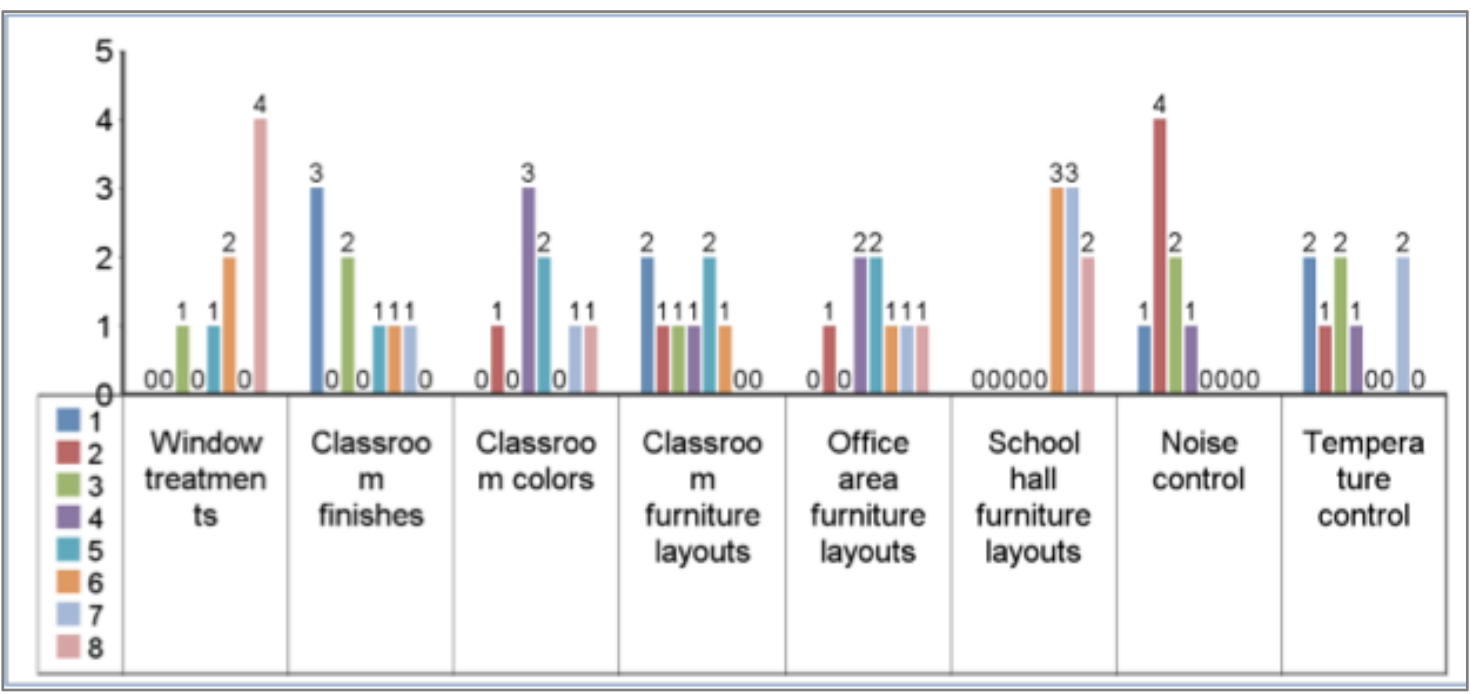

Figure 6-6: PARTICIPANT' RESPONSES to Q17 IN ARChITECTS' SURVEY.

\subsubsection{DISCUSSION}

The problem that architects notice most in their postoccupancy evaluation is noise control. However, they still take notice of the furniture layout, colours, and finishes in classrooms, which might reflect the fact they want to take good care of the environment inside these.

\subsubsection{EDUCATIONAL BOOKS AND THEORIES}

This section contained 2 questions about working with educational theories and teaching styles in designing learning environments. The first (Q18, $\mathrm{n}=12)$ has 4 statements, and the participants selected from a scale of agree (5) to disagree (1). Table 6-21 shows the different statements and the mean response to them. 
TABle 6-21: PARTICIPANTS RESPONSES TO Q18 IN ARCHITECTS' SURVEY.

\begin{tabular}{|l|l|l|l|}
\hline Statement & $\begin{array}{l}\text { Number of } \\
\text { responses }\end{array}$ & $\begin{array}{l}\text { Mean } \\
\text { response }\end{array}$ & $\begin{array}{l}\text { Standard } \\
\text { deviation }\end{array}$ \\
\cline { 1 - 1 } $\begin{array}{l}\text { I often read educational } \\
\text { books }\end{array}$ & & 3.83 & 0.94 \\
\cline { 1 - 1 } $\begin{array}{l}\text { I often read about } \\
\text { educational theories }\end{array}$ & \multirow{2}{*}{12} & 3.42 & 0.79 \\
\cline { 1 - 1 } $\begin{array}{l}\text { I integrate educational } \\
\text { theories in my designs }\end{array}$ & & 3.83 & 0.38 \\
\cline { 1 - 1 } $\begin{array}{l}\text { I attend educational } \\
\text { conferences (not related } \\
\text { to architecture) }\end{array}$ & & 2.17 & 0.72 \\
\cline { 3 - 4 } & & & \\
\hline
\end{tabular}

The second question $(\mathrm{Q} 19, \mathrm{n}=12)$ is "Name one educational theory you have been inspired by (if applicable)". Of the responses, 6 participants selected "not applicable" while the other 6 named theories or teaching styles they have used in their designs. The answers are in two categories, either teaching philosophies such as "personalized learning" or "project-based learning", or the physical learning space such as "Open plan rooms" or "The L Shaped classroom". Table 622 shows the architects' answers.

TABle 6-22: PARTICIPANT RESPONSES TO Q19 IN ARCHITECTS' SURVEY. 


\begin{tabular}{|l|l|}
\hline $\begin{array}{l}\text { Not sure if you would call it a theory but } \\
\text { 'personalized learning' }\end{array}$ & $\begin{array}{l}\text { Teaching style } \\
\text { environment style } \\
\text { Open plan rooms and teaching methods }\end{array}$ \\
\hline Project-based learning style \\
\hline The Language of School Design & Teaching style \\
\hline The L Shaped classroom - Nair \& Fielding & $\begin{array}{l}\text { Learning } \\
\text { environment style }\end{array}$ \\
\hline Learning through interaction with peers & $\begin{array}{l}\text { Learning } \\
\text { environment style }\end{array}$ \\
\hline
\end{tabular}

\subsubsection{DISCUSSION}

Half the participants have read educational theories and care about reflecting these theories in their designs, which is good in terms of designing suitable spaces for modern learning strategies and styles. However, ideally these readings should be matched by good communication with the teachers and students to connect the strategies in the theories to the methods used in the local learning environments. Such a connection could improve the design of learning environments for both teachers and students.

\subsubsection{CORRELATIONS IN THE ARCHITECTS' SURVEY}

Due to the low response rate in the architects' survey, the sample is too small to give significant correlations between questions in the survey. However, two correlations in the 
survey are presented here as examples of what might be useful for a larger participant pool. The first is to find out if architects who have completed more design projects are keener on involving students and teachers in the design process. The results are in Table 6-23, showing the mean responses are not different except when it comes to the question of involving students in the design of schools. The 9 participants' mean response is neither agree nor disagree, while the mean response for all participants is agree.

TABLE 6-23: CORRELATION TO FIND OUT IF ARCHITECTS WHO HAVE COMPLETED MORE DESIGN PROJECTS ARE KEENER ON INVOLVING STUDENTS AND TEACHERS IN THE DESIGN PROCESS.

\begin{tabular}{|c|c|c|}
\hline $\begin{array}{l}\text { The question / agree or disagree } \\
\text { (scale of } 5 \text { choices) }\end{array}$ & $\begin{array}{l}\text { Mean } \\
\text { responses from } \\
\text { all participants } \\
12 \text { participants }\end{array}$ & $\begin{array}{l}\text { Mean responses from } \\
\text { architects who } \\
\text { completed more than } \\
5 \text { projects, } 9 \\
\text { participants (Q3) }\end{array}$ \\
\hline $\begin{array}{l}\text { Working with teachers improves } \\
\text { the quality of school design }\end{array}$ & 4.25 & 4.11 \\
\hline $\begin{array}{l}\text { Working with children improves } \\
\text { the quality of school design }\end{array}$ & 3.58 & 3.44 \\
\hline $\begin{array}{l}\text { Working with teachers improves } \\
\text { the quality of classroom design }\end{array}$ & 3.92 & 3.67 \\
\hline $\begin{array}{l}\text { Working with children improves } \\
\text { the quality of classroom design }\end{array}$ & 3.42 & 3.33 \\
\hline $\begin{array}{l}\text { Teachers should be involved more } \\
\text { in the design process }\end{array}$ & 3.75 & 3.56 \\
\hline
\end{tabular}




\begin{tabular}{|l|l|l|}
\hline $\begin{array}{l}\text { The question / agree or disagree } \\
\text { (scale of } \mathbf{5} \text { choices) }\end{array}$ & $\begin{array}{l}\text { Mean } \\
\text { responses from } \\
\text { all participants } \\
\mathbf{1 2} \text { participants }\end{array}$ & $\begin{array}{l}\text { Mean projects, } 9 \\
\text { complects who } \\
\text { participants (Q3) }\end{array}$ \\
\hline $\begin{array}{l}\text { Children should be involved more } \\
\text { in the design process }\end{array}$ & 3.08 & 3.22 \\
\hline
\end{tabular}

The second correlation is whether the architects who use the Ministry guidelines, which support involving users in the design process, are keener on involving students and teachers in the design process. Those who use the Ministry guidelines for each educational project (3 participants) have similar responses to the rest of the participants except for involving children in designing schools, where the 3 participants' mean response is neither agree nor disagree, while the mean response for all participants is agree (Table 6-24). 
TABLE 6-24: CORRELATION TO FIND OUT IF THE ARCHITECTS WHO USE THE MiNistry gUIDELINES ARE KEENER ON INVOLVING STUDENTS AND TEACHERS IN THE DESIGN PROCESS.

\begin{tabular}{|c|c|c|}
\hline $\begin{array}{l}\text { The question / agree or } \\
\text { disagree (scale of } 5 \text { choices) }\end{array}$ & $\begin{array}{l}\text { Mean responses } \\
\text { from all } \\
\text { participants } \\
12 \text { participants }\end{array}$ & $\begin{array}{l}\text { Mean responses from } \\
\text { architects who use the } \\
\text { Ministry guidelines } \\
\text { for each project, } 3 \\
\text { participants (Q13) }\end{array}$ \\
\hline $\begin{array}{l}\text { Working with teachers } \\
\text { improves the quality of school } \\
\text { design }\end{array}$ & 4.25 & 4 \\
\hline $\begin{array}{l}\text { Working with children } \\
\text { improves the quality of school } \\
\text { design }\end{array}$ & 3.58 & 3.33 \\
\hline $\begin{array}{l}\text { Working with teachers } \\
\text { improves the quality of } \\
\text { classroom design }\end{array}$ & 3.92 & 4 \\
\hline $\begin{array}{l}\text { Working with children } \\
\text { improves the quality of } \\
\text { classroom design }\end{array}$ & 3.42 & 3.33 \\
\hline $\begin{array}{l}\text { Teachers should be involved } \\
\text { more in the design process }\end{array}$ & 3.75 & 3.67 \\
\hline $\begin{array}{l}\text { Children should be involved } \\
\text { more in the design process }\end{array}$ & 3.08 & 3.33 \\
\hline
\end{tabular}

Although only indicative, these responses suggest that the more experienced architects with more successfully 
completed projects do not see a need to involve children. At the same time, despite the Ministry guidelines' promotion of a collaborative design process, this message does not seem to be getting through. Perhaps more visual examples of buildings and classrooms that result from such a collaborative approach would carry more weight with architects.

\subsection{COMPARISON OF TEACHERS' AND ARCHITECTS' SURVEYS}

In this section, responses to shared questions in both the teachers' and architects' surveys are discussed. These are in two categories. The first is a group of agree or disagree statements, while the second category is about the party responsible for selecting furniture, colour scheme, and finishes in the classroom.

In the agree and disagree category, there are six statements to which both architects and teachers responded. The statements and comparison between participants' responses, using SPSS, are shown in Table 6-25. 
TABLE 6-25: THE FIRST CORRELATION BETWEEN ARCHITECTS' AND TEACHERS' SURVEYS.

\begin{tabular}{|c|c|c|c|}
\hline Statements & $\begin{array}{l}\text { Respons } \\
\text { es: } \\
\text { Teachers }\end{array}$ & \multirow[t]{2}{*}{$\begin{array}{l}\text { Mean } \\
\text { difference } \\
\text { (SPSS) }\end{array}$} & \multirow[t]{2}{*}{ Results } \\
\hline & Architect & & \\
\hline $\begin{array}{l}\text { The principal of the school } \\
\text { is the decision maker in the } \\
\text { design process }\end{array}$ & $\begin{array}{l}3.46 \\
3.50\end{array}$ & -0.045 & $\begin{array}{l}\text { The mean response } \\
\text { is considered the } \\
\text { same for both } \\
\text { teachers and } \\
\text { architects }\end{array}$ \\
\hline $\begin{array}{l}\text { The project manager is the } \\
\text { decision maker in the } \\
\text { design process }\end{array}$ & $\begin{array}{l}2.95 \\
2.70\end{array}$ & 0.249 & $\begin{array}{l}\text { The mean response } \\
\text { is considered the } \\
\text { same for both } \\
\text { teachers and } \\
\text { architects }\end{array}$ \\
\hline $\begin{array}{l}\text { Architects have no chance } \\
\text { to talk with teachers }\end{array}$ & $\begin{array}{l}3.25 \\
1.92\end{array}$ & 1.331 & $\begin{array}{l}\text { The mean response } \\
\text { is considered } \\
\text { different for both } \\
\text { teachers and } \\
\text { architects }\end{array}$ \\
\hline $\begin{array}{l}\text { Architects have no chance } \\
\text { to talk with students }\end{array}$ & $\frac{3.72}{2.25}$ & 1.473 & $\begin{array}{l}\text { The mean response } \\
\text { is considered } \\
\text { different for both } \\
\text { teachers and } \\
\text { architects }\end{array}$ \\
\hline
\end{tabular}




\begin{tabular}{|c|c|c|c|}
\hline \multirow{2}{*}{$\begin{array}{l}\text { Teachers should be } \\
\text { involved more in the } \\
\text { design process }\end{array}$} & 3.99 & \multirow[t]{2}{*}{0.903} & \multirow{2}{*}{$\begin{array}{l}\text { The mean response } \\
\text { is considered } \\
\text { different for both } \\
\text { teachers and } \\
\text { architects }\end{array}$} \\
\hline & 3.08 & & \\
\hline $\begin{array}{l}\text { Children should be } \\
\text { involved more in the } \\
\text { design process }\end{array}$ & $\begin{array}{l}4.60 \\
3.75\end{array}$ & 0.846 & $\begin{array}{l}\text { The mean response } \\
\text { is considered } \\
\text { different for both } \\
\text { teachers and } \\
\text { architects }\end{array}$ \\
\hline
\end{tabular}

The comparison between responses indicates that teachers and architects neither agree nor disagree about the decision maker in the design process being the principal or the project manager. This may indicate that the principal is the decision maker or that it is not clear in who is the decision maker in the design process.

In terms of involving students and teachers in the design process, the responses are different. Architects' responses indicate that the involvement of teachers and children in the design process is already happening, while teachers neither agree nor disagree on the involvement of children, while they agree that architects have no chance to talk with teachers. Architects neither agree nor disagree on involving teachers more in the design process, while teachers want to be involved more. Architects agree on involving students more in the design process, while teachers strongly agree with 
doing this. The different responses here may indicate that teachers see the involvement differently from architects, who may feel that what is already happening is enough. The responses show that teachers might be more concerned about user participation in the design process than architects.

In terms of the second category of shared questions, Table 626 shows the different responses of architects and teachers on who selects the furniture, colour scheme, and finishes of the classroom. They had to select from a list that includes the principal, project manager (PM), architect, teachers, students, and the Ministry of Education (MoE). 
TABLE 6-26: THE SECOND CORRELATION BETWEEN ARCHITECTS' AND TEACHERS' SURVEYS.

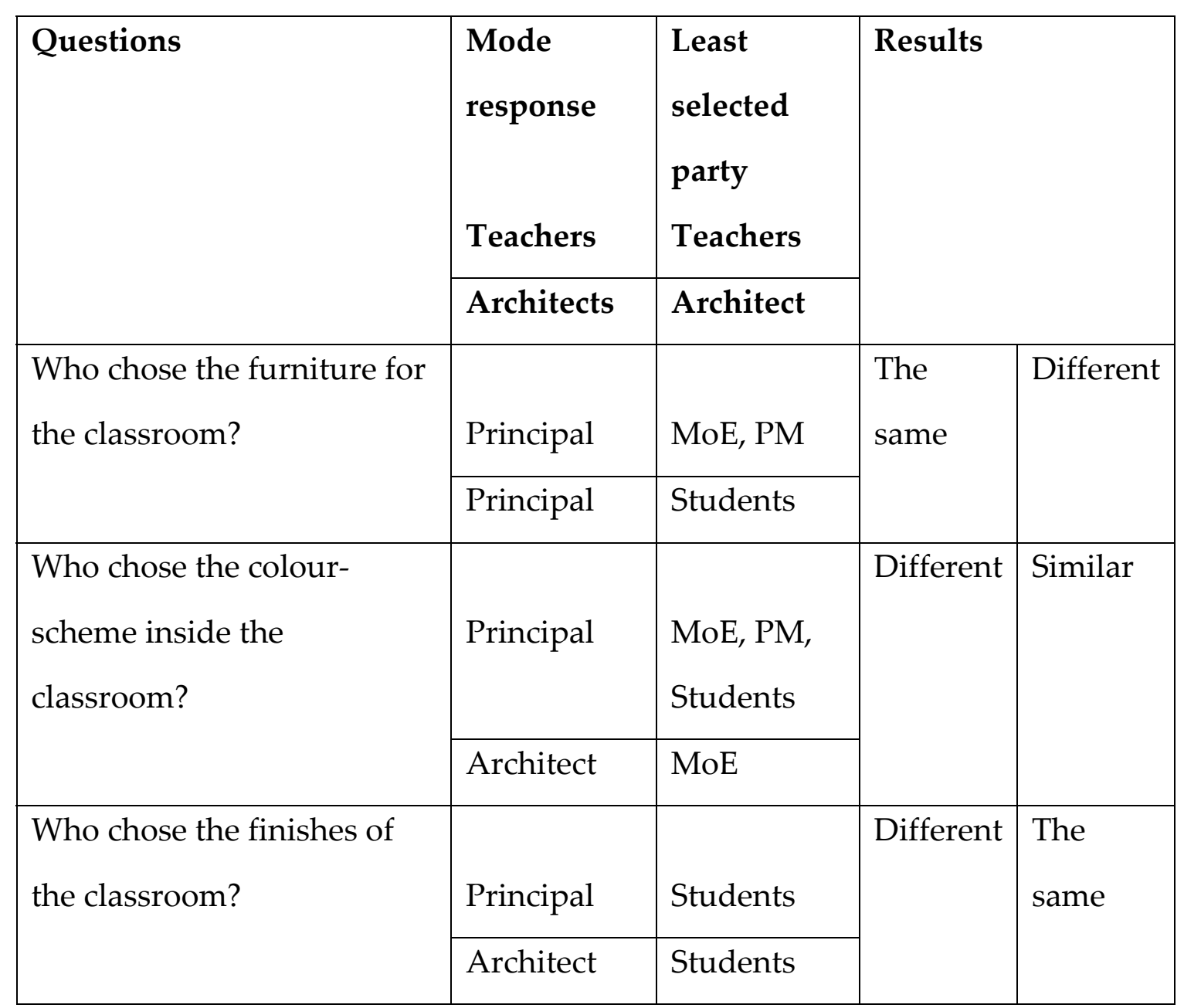

Teachers think that the principal is the decision maker in all the listed decisions, while the architects claim that the principal is responsible for furniture selection and architects are responsible for the classroom colours and finishes. This may indicate again that the design process is not clear for teachers. They might have no idea who is selecting what they see and use in the learning environments they inhabit every school day. In terms of the least selected parties, students are mentioned by architects and teachers in the three questions. 
That may indicate that the involvement of students is not undertaken very well. Students may not be the ones to make the final decision, but they could still have a say in these decisions.

\subsection{COnClusions}

The main conclusion of this chapter is the agreement of both architects and teachers on the fact that users (teachers and students) need to be involved more in the design process of learning environments. Both teachers and architects support user involvement in the design process of learning environments. This in turn indicates a need to discover or create methods that encourage this involvement for all parties. This phase of the research also indicates there are issues with the guidelines provided by the Ministry of Education. The Ministry of Education should consider improving or clarifying the guidelines for a better design process in learning environments, especially through the provision of appropriate examples with clear explanation of how and why these better learning environments are achieved. The Ministry also needs to give clearer support to user involvement in design through showing how teachers and students could be involved in the process and what learning environments result. The last issue raised in this phase of the research is the role of school principals, who manage and control almost all the design process even though they are not using the environments being designed. This issue may reflect a situation where the principal is taking over 
and not giving the staff the chance to participate, but it could also indicate that it is easier for architects just to work with one key figure as the client representative. It is also hard for architects to design an ideal learning environment when they have no control over the type and amount of furniture that will be used in it.

Many questions have arisen during the analysis of these surveys, some of which need further research, which falls outside the scope of this thesis. However, given the aim of the thesis is to consider how a more collaborative design process could be established for New Zealand schools, chapter 7 sets out a number of case studies that were established to explore this issue further. 
Chapter 7: Phase Two, Three, Four, And Five 


\section{Chapter 7: Phase TWO, THREe, FOUR, AND FIVE.}

Chapter 6 indicated that architects and teachers supported a collaborative approach in the learning environment design process. However, they did not know or could not clearly describe what form this might take. Thus, a further investigation was needed to form a clearer image about possible methods of user involvement, especially that of children, in the design process of learning environments in New Zealand. A number of small studies were conducted to gather information that would contribute to this investigation. This chapter aims to explain the details of these studies and how they helped in uncovering knowledge about the design process of learning environments in New Zealand primary schools.

Chapter 7 thus deals with the four further phases of the research that follow the surveys conducted in phase one, with each main section corresponding to one of the four phases. The main sections comprise an experiment in the use of social media in the design process of learning environments; a workshop with teachers and architects with same focus; a case study of a Wellington primary school rebuilding project focusing on user involvement; and finally a case study involving two groups of students in changing the layout of their existing classrooms. Each main section contains subsections to cover the aim, the methods used, findings and 
discussions. More details about the phases are discussed within the subsections.

\subsection{Phase TWO: USING SOCIAL MEDIA TO INVOLVE USERS IN THE DESIGN PROCESS}

Phase two was an experiment that tried to involve users of learning environments in their design process through testing possible IT methods to link the designers with the users, although the focus was on seeing whether the users could use social media to communicate their design ideas. The work involved a number of prepared exercises for the students. The five subsections explain the background literature on using social media in the design process, aim and sub-research question, methodology, findings, and discussion of the results.

\subsubsection{BACKGROUND LITERATURE ON USING SOCIAL MEDIA IN THE DESIGN PROCESS}

Social media is a set of applications permitted by the Internet that allow individuals to gather in virtual locations and communicate and share material easily (Reyes \& Finken, 2012). Social media can be in different forms, such as mobile communication through Short Message Service (SMS) and picture messaging; social networking and media sharing sites as in Facebook, Flickr, and YouTube; or open blogging tools as in Wordpress and Tumbler (Hagen \& Robertson, 2010).

15 ago, the use of the Internet was limited to experienced people, such as skilled computer programmers or those with a fairly good understanding of network applications. At 
present, people do not need that detailed experience to use the Internet, although they still need to become familiar with some basic operations. People like to have these set out in an easy-to-use manual or as on-screen instructions. Thus using online media in participatory design needs precise and sensibly designed tools that will create environments that are attractive for their potential users. Another thing to consider in using social media for participatory design is the openness of discussion on the social media open forums (Näkki \& Antikainen, 2008), which may be unwanted for this application. The aim behind using social media for participatory design is to increase the quality of products or services through approaches where designers and developers can communicate with and involve the users (Johnson, 2013), and some of this may need to be confidential.

A study completed by Reyes (2012) indicated how a traditional method for participatory design could be interpreted and used with social media using Facebook as an example. Reyes explained how he explored the use of Facebook in participatory design through designing a mobile application that involved a group of design participants. The project started with several meeting involved Reyes, the project leader, a supervisor from the research facility, and a communication advisor. The main aims were to establish a media site that encourages the public to become active in stabilizing and developing heritage photographs, and to make these photographs available so other people could 
make comments on them and other contributions to the site. Facebook was used to achieve these aims and was chosen because of its popularity and its ease of access. There were 18 participants including the project owners, designers and users. The Facebook workshop had a number of different phases which broke down into a critique phase, where participants gave their opinions about the heritage photo service and gave ideas for improving it, a fantasy phase where participants were asked to imagine their ideal service and explain it, and finally an implementation phase where the best ideas from the fantasy phase as selected by the participants were improved and developed to the final service design. The main result of this study is that the use of Facebook improved the value of traditional methods of participatory design, especially as Facebook is well known and consequently most users or participants do not have to spend time becoming familiarized with the different media and methods. Social media can also allow more interested people to participate through using popular media that do not require changing the location of the participants or spending a long time becoming involved in the design process. Participants can be involved in the design wherever and whenever they want, and, with the appropriate steps in the design on the site, without having to give their identities. Participants, through the online media, can receive feedback about their work and can also be easily informed about the progress of the design process. The only disadvantage might be that participants 
may not be able to meet other participants, which could cause them to miss the feeling of being in a community involved in a process of change.

Another work involving online participatory design is the open web lab Owela. Owela is an online media site created to enable co-designing or participatory design between users, customers, developers, and stakeholders in order to complete the design of anything they desire. Owela is considered to be social media, as it offers interaction between members of a society regardless of time and place. Owela also provides a set of tools and methods to facilitate participatory design through discovering user needs and experience. Over 40 different types of participatory design case studies have used this web lab. Examples for projects that were completed via Owela include user-driven software development, a consumer study of cloud software, generating ideas and concept evaluation, and public co-design of a multicultural web community called Monimos. In these projects, consumers and citizens communicated and interacted with companies and researchers to create new products or services such as a city tourism service. Most of the examples focused on the early stages of the innovation process, such as collecting information about user needs, creating ideas, and assessing new product and service concepts. Users can participate from anywhere, as they only need Internet access and basic knowledge of using social software. Using this software saves the users time and effort. With Owela, 
designers and developers can reach large numbers of users quickly and easily. Participation in Owela can also be to different degrees of involvement as the relationships and communication through the media site can be long-term or short-term depending on the requests and needs of the users and designers. Owela does not guarantee the production of successful designs, as this will depend on the aims of the project and how effective the communication between participants is. Users of Owela also found this media useful, as they had the chance to obtain feedback from users and developers without having to attend direct feedback sessions (Kaasinen et al., 2013).

\subsubsection{AIM AND RESEARCH SUB-QUESTION:}

The results of the surveys (see section 6.5) indicate that teachers and architects support the involvement of learning environment users in the design process. However, no obvious methods for this involvement emerged. From the surveys and exploratory focus groups discussions, any involvement of teachers and students apparently happened through random consultations and meetings. The survey also showed very few teachers and students have been involved in the design process. Thus, phase two of this research set out to create and test a medium whereby there could be more user involvement in the design process of learning environments.

For participatory design (see section 3.1), users of designed environments should work alongside designers. In the case of 
primary school learning environments, designers and architects might find it hard to work with young users, in addition to the difficulty of having a large number of users to deal with. In this case study, the aim is to examine how social media can affect the participation of users in the design process of learning environments. The current absence of methods for involvement could affect the level of user involvement, creating a need to invent new methods and then test these. Thus the research sub-question is: How useful are social media in enabling the participation of students and teachers in the design of their learning environments?

This second phase also reveals the problems of using social media to involve users of learning environments. Unfortunately, the trials designed to investigate this were not completed as planned, as there were insufficient responses. However, the experiment is discussed in the following sections and the few findings are analysed.

\subsubsection{Methodology}

As this phase aimed at trying to use social media as a means of user involvement, an experimental methodology was selected.

The creation of a blog was based on Groat and Wang (2002) and their description of designing experiments for architectural research. Their methodology includes studying the effect of identifiable variables in the research. The variables can be manipulated or controlled by the researcher in order to consider suitable treatments in the experiment. 
In this study the variables are the work of students uploaded to the blog that was created for the experiment and their teachers' comments and posts. The work of the students was determined by the exercises provided in the blog. Thus, the exercises were designed carefully given that they were dealing with young minds. For this project, a large part of the background on how to research and work with young people was taken from Thomson (2008). The research also built on the experience of working with primary school age children for the earlier Master's thesis (see Chapter 1), through observing and interviewing them and in drawing sessions (Alsaif, 2011).

Another part of the methodology, used in Groat \& Wang study, was identifying the units of the experiment and treating them with a manipulated management (Groat \& Wang, 2002). In this study, students' work was grouped into categories based on the main idea behind it. For example, the work might reflect what they like or dislike about their existing environments, or it might be complaints about the furniture in the learning environments, or ideas about future learning environments and their furniture and fixtures. Managing the ideas was accomplished by defining problems with existing learning environments and finding suitable solutions from the ideas for future learning environments. It was felt the blog could also help in understanding the ideas and in sorting out the problems and solutions through the online discussions it offers. 
Generally, lab research is more likely to take causality for granted than research that involves the reactions or behaviour of people. Thus, studies about people's reactions and behaviour tend to focus on the conditions and limitations of a causal interpretation (Groat \& Wang, 2002). In order to help define the limitations and conditions of this experiment, teachers were asked to attach information to each piece of student work. The information could include the age of the student, the type of existing learning environment (single cell or open plan), how much time the students spent on the work, and the environment in which the work was completed. The blog was thus set up to encourage teachers to set the exercises in limited conditions; for example, for the suggested target group of students aged 9-11, the work was to be completed within one school day, and the environment within which the work was done was to be the same learning environment as dealt with in their work.

At the end of the experiment, the results of designing using the blog were intended to be compared with the current process used in New Zealand to design learning environments, as described by primary school architects in the phase one survey (see section 6.3).

\subsubsection{AN OUTLINE OF THE BLOG}

To answer the sub-research question, phase two created an experimental blog supported by exercises for the students to encourage them to produce suitable ideas for designing learning environments. Although two exercises were 
supplied, teachers had control of using these with their students. They also had to upload the students' ideas and thoughts about designing their learning environments. The blog was designed to allow students to look at the work of other children in different schools under the supervision of the teachers. Although at this stage architects were not involved, it was envisaged that in real projects architects and designers would be able to access these ideas easily with a view to their possible integration into designs for learning environments. Alternatively, they could discuss the ideas with the users (teachers and supervised students) through the comments in the same blog. It was hoped this experimental methodology would save time and make the communication between architects and students easier than face-to-face meetings.

The blog was intended as a private place, with only invited participants having access. It contained the two set exercises to help teachers introduce the task to students in a series of well-described steps. The first exercise aimed to encourage students to produce ideas and thoughts about their current learning environments, while the second was about future and ideal learning environments. Figure 7-1 shows the blog's structure. The students' work could be individual or group work. The format of the work could be in any media chosen by the students, such as written format, manual or digital drawings, video recordings, and voice recordings. The blog 
also provided a tutorial on how to upload and post student work.

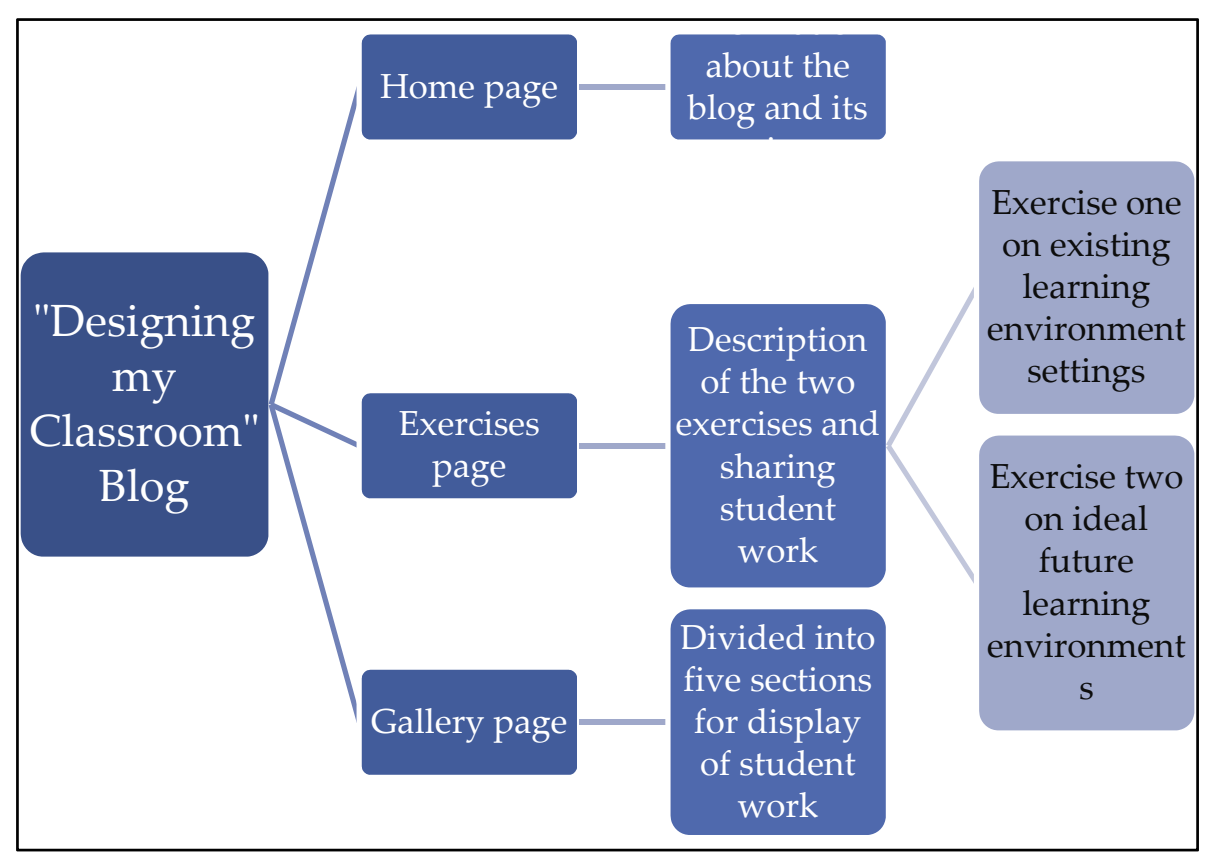

Figure 7-1: The structure of the blog "Designing My CLASSROOM"

\subsubsection{DifFiCULTIES WITH THE EXPERIMENT}

Measuring the outcome of the blog could not be completed as originally envisaged because of the very low response rate. The posts from the participatory design blog were supposed to be discussed in the workshop in phase three of the research, but again this was not really possible for two reasons. The first is that the posts from the blog were too few and really only represented the users of one classroom. The second reason 
was that participants of the workshop only included one architect, which is insufficient for discussing a true measurement of the blog outcomes.

There were also no discussions about the posts and the ideas on the blog that could have been analysed in terms of the problems with and solutions for a participatory design process. The absence of the measurements of the outcomes and the lack of discussions that could have formed a base for them meant the experiment was incomplete. Thus the results of the experiment are not reliable and should be treated as indicative.

\subsubsection{CASE STUDY AS A BACKUP PLAN}

As the experiment could not be completed with so few posts, phase two used a case study method for analysis. The posts, including students' work, formed a case study, which then needed specific information to be completed. The question for this case study became: How can participants in the blog contribute in a design process through using social media? The proposition of this case study is that teachers and students have enough knowledge to be able to participate in the design process of their learning environments. The units of analysis include teachers, students, and their posts on the blog. The data is collected from these posts in the form of documentation. The findings (see section 7.1.4) provide analysis and discussion of the experiment and case study methods. The case study methods are explained again in more 
detail in phases four and five of the research, where they were also used.

\subsubsection{FINDINGS}

In June 2013, a follow-up invitation was sent to primary school teachers throughout New Zealand to participate in the phase two experiment. It was disappointing that only 16 teachers accepted the invitation and of these only 3 posted material on the blog in response to the exercises. Given this low response an alternative social media, a Facebook group, was developed, in the hope it would be more popular than a blog. As a result, in September 2013, a Facebook group with the same aims and exercises as the blog was initiated and invitations were again sent to primary school teachers around New Zealand. Twenty-seven teachers accepted the invitation. However, none of them posted anything related to the exercise or their involvement in the design process of learning environments.

Some members of both the Facebook group and the blog declared that they were happy to participate in these social media and were using the exercises with their students but nothing has been posted as of the writing of this thesis. It seems that teachers, as they said in the survey, like the idea of getting involved in collaboration and using these social media but find they are too busy for actual involvement. 


\subsubsection{POSTS IN THE BLOG}

In June 2013, the blog opened to participants for sharing their ideas. It was introduced through the survey sent to all primary schools in New Zealand. In the survey 50 teachers responded positively to being part of the blog but only 16 accepted the invitation to join. At the time of writing there are only three posts in the blog, suggesting that although teachers like the idea they might be too busy to participate.

In the first post (post 1), a teacher and her students completed exercise one. There were no drawings, sketches, or photographs in this post. They started the exercise with a brainstorming session about the current layout of their classroom, which is a single cell classroom with one wall of windows, a front door, an art bay, and a door leading to the cloakroom bay. The teacher mentioned not having a veranda and expressed her feelings about that with a 'sad face'. Then the students started to list what they liked and did not like in the learning space. Likes included the interactive settings in the classroom, such as the interactive whiteboard, the computers, iPads, and a fishbowl with two fish. Students like the fact that they change seats every week. They also like the natural light coming through the windows and the fact that some desks are located by these. They like some of the storage units, as they provide a good place for classroom stuff such as the iPads, laptops, maths equipment, and classroom books. The teacher said that they like the teacher's desk being in the art bay (in the cave area). Students like the fact they can 
change their seats and that they do not have fixed place for the whole school term. In addition, they like having the option of sitting on cushions on the floor.

In terms of their dislikes, they do not like the location of some settings, such as the bookshelf at right angles with the computer cupboard or having a shoe rack inside the classroom by the window. They also do not like the mess created by the cords by the computer tables. They would like to add some furniture, change some, and change the location of other pieces. However, there was no discussion of why they had these dislikes, although some of this emerged in the students' drawings from the second exercise. They have, however, changed the desks to tables, as they find tables encourage students not to be attached to one particular workspace (the student's desk). Instead, they have the choice of changing their workspace during activities. The teacher also claims that the tables are easier to move than desks when they want to create a furniture-free space for certain activities. They want to add more tables and storage boxes to the classroom, as unlike desks, tables do not have places to keep books and pens. They would like to move the jellybean shaped tables to the reading corner. They would like to change the location of the interactive whiteboard, as when the sun enters the room it shines into their eyes when they are looking at it. In terms of participating in the classroom design the teachers said that students have the option to work on any setting inside the classroom such as at desks, on tables, on the 
floor, move around, or with laptops/iPads. However, they do not usually choose the layout of the classroom furniture or the location of the settings inside the classroom.

The second post (post 2) was also about exercise one. The teacher and her students started by talking about the layout of their classroom. The classroom was a fully carpeted room with a sink, shelving, wireless controller, "two work stations", high windows, individual desks grouped in fours, and an interactive whiteboard. The classroom had a door leading to a veranda with some seating, and the other door leads to the cloakroom bay and toilets.

They also listed what they like and do not like about the classroom. They like the interactive board, the two workstations, the wireless service, as it enables them to use the laptops at any time and in any place, and they like the large area on the walls for display of things that help students to learn, such as the world map showing the students where their families are from. They like the fact they have a fishing net hung from the ceiling and that they use it for learning purposes, such as catching the vocabulary words that are new to students. The teacher said that they like having the books in desk trays. On the other hand, they dislike not having a proper wet area, as this makes the sink area a mess; the fact there is not enough space in the mat area and that the colours of the classroom are dull (they would like bright colours). They also have an overheating problem, as not all windows 
have proper treatment, which lets the afternoon sun in, heating up the classroom. They claim that desks are too low for some students and the chairs are uncomfortable.

In the third post (post 3), the teacher (the same teacher, students, and classroom of post 1) asked her students to redesign their existing classroom in a way they would like. The teacher gave them a floor plan with which to start redesigning the existing internal layout. Not all the students of the classroom participated in this exercise. Students worked in pairs or individually and produced 11 redesigned floor plans (Figure 7-2). Students completed the exercise inside their current classroom.

In the first drawing (Figure 7-2-A) the student drew the existing layout of the classroom, as she likes it as it is. In the existing layout the cave area has the teacher's desk in addition to the art bench that includes a sink. The tables are located in the centre of the classroom for group work. There are some storage units and a small furniture-free area for mat time. Having this drawing was very useful, as the ideas of other children could be compared against the existing layout. This highlights the importance of having a drawing of the existing classroom layout at the start of any participatory design activity.

In the second drawing (Figure 7-2-B) the student kept the teacher's desk in the cave area. There was less furniture than in the existing classroom layout, which creates more furniture-free space for mat time or free movement of 
students. The desks and tables were arranged for students to work in groups. In the third drawing (Figure 7-2-C) the cave was used for student activities instead of for housing the teacher's desk. In this layout, there were desks and tables for individual and group work. The fourth drawing (Figure 7-2D) divided the classroom into mini rooms for different activities, such as a reading room, play room, writing room, and "treat" room. This layout had windows on all the classroom walls in order to light all these rooms. Some rooms have no furniture, which creates more space for students to move, learn, and play freely. In the drawing (Figure 7-2-E) the cave was also converted to serve students' activities. The whiteboard and mat area were obvious in this layout in the top left corner. The students furnished the mat area with cushions and arranged the desks to serve both individual and group work. There were also some furniture-free spaces for free movement. In Figure 7-2-F, the drawing showed less furniture to create more empty space for free movement. The students who completed this drawing included some details, such as the lighting units and location of windows. Windows were located on all classroom walls for maximum natural light. In Figure 7-2-G, the student made the cave an area for student activities and moved the teacher's desk to another corner. Also included were some activity corners and settings around the classrooms. The main observation from this drawing was that the desks are arranged in the traditional way, with rows of individual desks facing one side of the 
classroom. In another design (Figure 7-2-H) the students also suggested group tables for student group work and included activity corners around the classroom. Details covered the location of the heat pump. In another scheme (Figure 7-2-I) the drawing shows very similar ideas to the previous drawings, which included having group work tables and some activity corners. There was also a noticeable couch introduced in this layout. The last two drawings (Figures 7-2$\mathrm{J}$ and $\mathrm{K}$ ) were also similar to the other drawings, with group work tables and activity areas. The teacher's desk was kept in the cave area in both these drawings. 

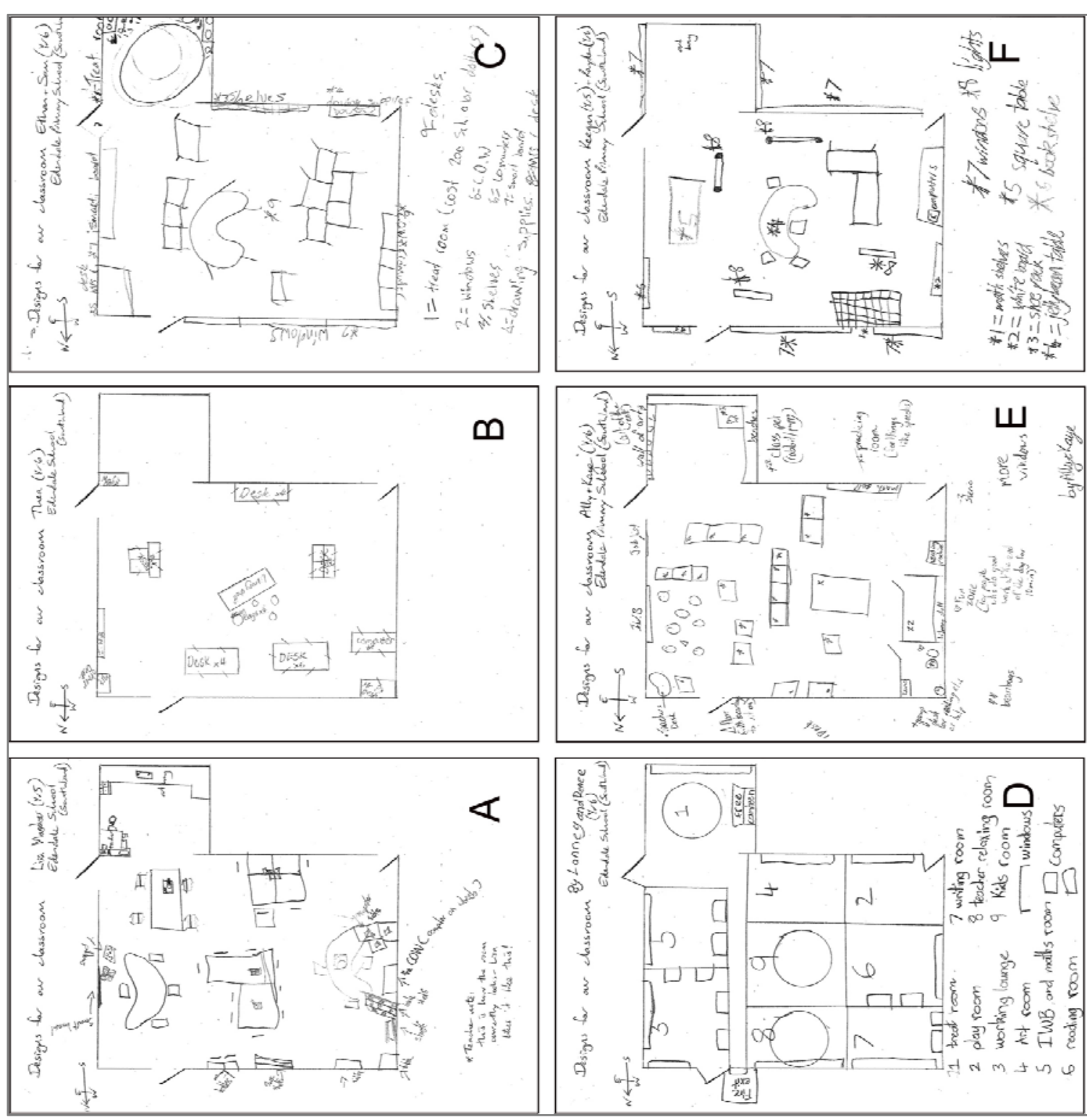

FIGURE 7-2A: STUDENT DRAWINGS IN POST 3 ON THE BLOG. 


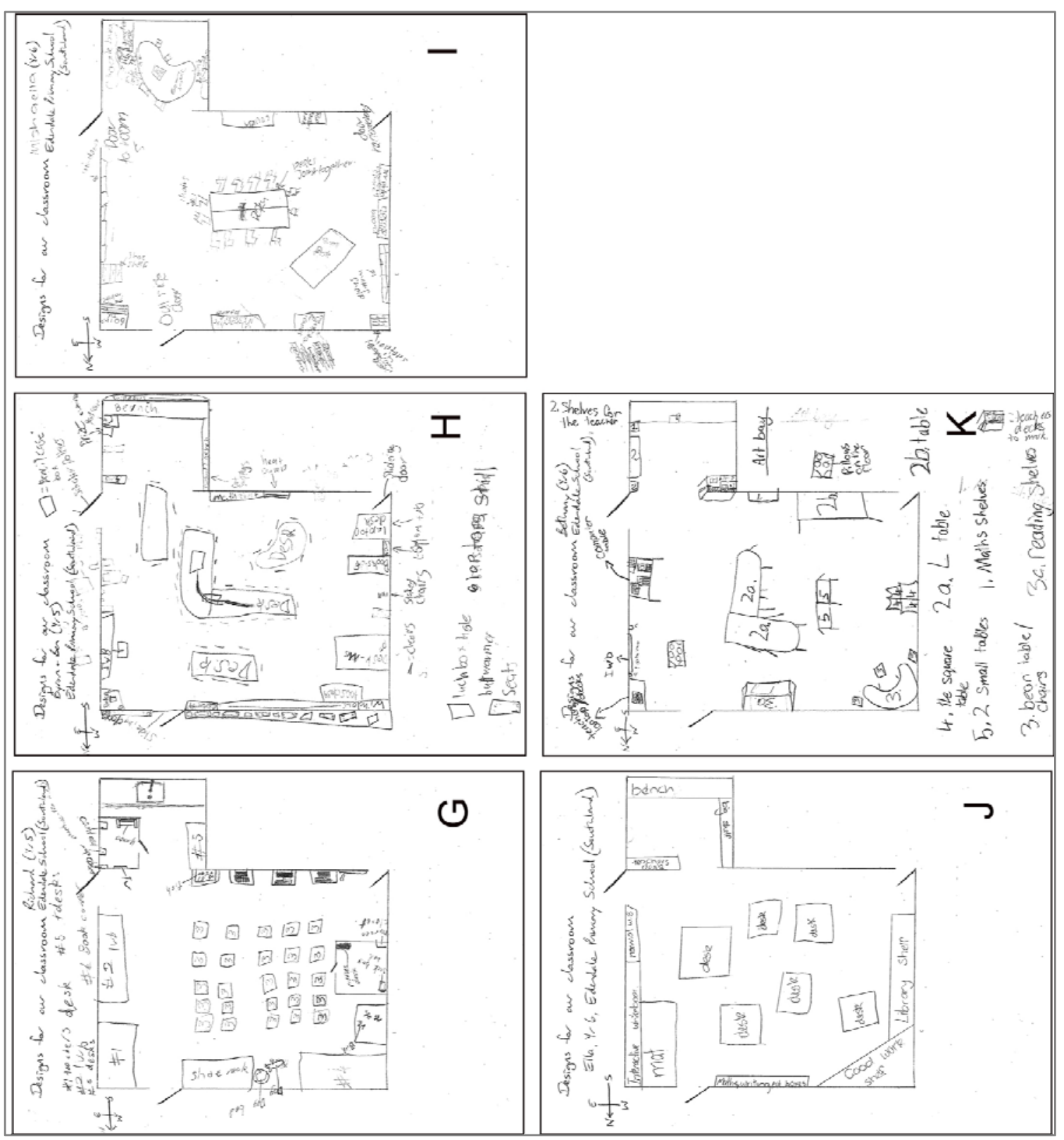

FigURE 7-2B: STUDENT DRAWINGS IN POST 3 ON THE BLOG.

\subsubsection{DISCUSSION OF THE POSTS}

This discussion first considers the commonalities in the posts and drawings, then the limitations of the exercises, and finally some overall comments on the use of social media. 
The posts reveal common ideas when it comes to the likes and dislikes within the existing learning environments. Teachers and their students like the use of technology inside the classroom, such as the interactive whiteboard and the laptops. They like to have some space free of furniture for various activities, and this is reflected in the drawings, as students drew less furniture than the existing and created new furniture-free spaces. This liking for furniture-free spaces could be because it gives young students more freedom to play, move around and be creative in completing their set activities, rather than being stuck in a chair. In all students' drawings, there was a problem in the scale. Students could not reflect the actual scale of the classroom furniture. Thus, they might feel that they can have more furniture-free space with the same furniture and settings. However, some students created more empty space by putting fewer pieces of furniture in the classroom, which may indicate that these students prefer working and learning freely on the floor more than using furniture. Students created group work stations in all their drawings, which probably reinforces how much they like to work in groups, although it may also reflect what they already have in their existing classroom. In the third post, some students converted the cave area, which is currently used for art and the teacher's desk, into a space that is only for student activities. This indicates that students like to have a semi-private corner for quiet activities such as thinking or reading. Students also show in their drawings that they like 
windows and natural light. This is also mentioned in the likes of one of the posts, where the teacher said that students like to sit by the windows. Only one student suggested a traditional desk arrangement, which may indicate that the majority of students prefer modern layouts that involve different activity settings that cater for different teaching and learning styles.

In terms of limitations, students may have not been in other types of classroom so their ideas are extensions of what the current classroom offers or reflect their previous experiences of classrooms. The exception is the two students who divided the space into many separate rooms for different functions. Thus, it seems students' ideas might be limited, as they do not know what could be changed or what other potential options exist. The teacher in the third post said that for most of the students this is the only type of classroom they have ever worked in. Thus, they might have no idea about how the classroom shape or type could be changed.

In the drawings, the teacher gave her students the outline of the classroom for them to draw their different layouts on and she said that this might be the reason that no student tried to change the classroom shape, although the students who proposed 7-2-D did change its architecture. It was noticeable that student ideas were expressed only in plan form and noone drew either a sectional or three-dimensional representation (see section 3.3.2). This may be the fault of the exercise in not suggesting that both a plan and section of the 
existing classroom should be the starting point for the student work.

In terms of overall comments, in the blog teachers did not explain why they did not change the classroom layout. This could be because of the budget or the fact they need the approval of the board of trustees to make a change. However, there are minor changes teachers can make without spending any money, such as moving the furniture.

Another issue for comment is that in the first post the teacher said that they would like to have more tables in the classroom and in the third post the students of the same classroom expressed their need to have furniture-free spaces. This may indicate that the classroom needs to be bigger to serve the needs of all users, or that teacher and students need to discuss and decide which strategy is more important in the classroom for the best learning environment.

Finally, the main comment on the students' drawings is that students produced, with the help of their teacher, architectural floor plans. For their age, these drawings indicate that students are ready to participate in the design process of learning environments. They understand what the classroom layout means and can deliver their ideas for this, both in discussion sessions and through their drawings.

\subsubsection{CONCLUSIONS FROM PHASE TWO}


The preliminary results for the blog and Facebook group show that teachers did not appear to have the time to get involved in these online social media sites to explore classroom design with children as a general topic. This suggests that using online social media may not be the best way to increase user involvement in the design process of New Zealand primary schools, although this conclusion may be influenced by the fact the very few participants were not currently involved in a school building or renovation project. In all the sections, the results produced by the children (mostly drawings) would allow architects, teachers, and the Ministry of Education to interpret the ideas into new designs, find solutions to common problems in existing classrooms, or be used as a base for guidelines for the design of learning environments in primary schools.

The posts completed by students revealed that they were ready to have a role in the design process of learning environments. Students can understand the elements of designing spaces. They thought about the shell, which is the architectural borders of the space, by deciding the locations of doors and windows and by creating different rooms. They thought about the interiors when they changed the space layout and removed some furniture.

\subsection{Phase THREE: WORKSHOP}

Phase three was a workshop with the intent of gathering together teachers and architects to discuss possible options for user involvement in the design process of learning 
environments in New Zealand. The workshop involved a number of exercises and discussions as following. The four sub-sections explain the aim, methodology, findings, and results of the workshop and its exercises.

\subsubsection{THE AIM OF THE WORKSHOP}

The surveys in phase one indicated that teachers and architects supported user involvement in the design process. Phase two set out to see whether social media would be a way to involve more users in the design process, but the results were inconclusive because of the very small sample, although the latter suggested that teachers were not sufficiently motivated to take part or felt they did not have the time to do so. This might change for a real school design project. The original aim of the phase three workshop was to discuss suitable methods for users to be more involved in the design process of New Zealand primary school learning environments, with a specific focus on classrooms. Despite the failure of the social media experiment, this aim still stood.

\subsubsection{PhASE THREE METHODS}

The workshop was set up as a face-to-face focus group. Focus group methodology was chosen because it was quick and easy to set up. The teacher and architect participants also needed a quick and easy method, as both are very busy groups of people. Another reason for using focus group methodology was that an active group can provide useful information that individual data collection does not. The focus group suited the aim of the workshop very well, as 
ideas and opinions were needed to create a vision about any new methods of involving users. The aim of this workshop was to explore the specific views of architects and teachers about participation in the design process. Because, according to Kitzinger (1994), focus group methodology is a group of discussions aiming to explore certain issues about people's views and experience, this seemed an appropriate method. The aim is to define the understandings of the selected group of participants toward a certain topic in order to achieve details and explanations about the topic (Liamputtong, 2011). There are two main keys for any focus group: developing the focus group guide or outline and deciding the number and type of participants (Department of Health and Human Services, 2008).

\subsubsection{OUTLINE OF THE WORKSHOP}

In terms of developing the focus group outline, there was a need for a group of questions based on the results of phase one and two. Questions would be asked by the facilitator (the researcher) and answered by discussions between participants (Department of Health and Human Services, 2008). The questions for this focus group were divided according to the different parts of the focus group outline (Figure 7-3).

The workshop was divided into three main parts, each with its own discussion session. After introducing the workshop and its aim, the first part consisted of a short presentation that included the survey results from phase one, presentation of 
the various methods used overseas for involving users in designing learning environments, and the benefits of this approach for schools in general. The second part (exercise one) was then introduced. In this, participants were to discuss the methods available for user involvement in the design process in New Zealand leaning environments and the potential advantages and disadvantages of using these. The exercise was followed by a discussion, which led to a summary of the results of the exercise. The third part (exercise two) was to discuss the relationship between architectural borders (the shell) and the internal layout. The exercise involved displaying what students achieved in the blog post from phase two. This exercise was also followed by a discussion session, leading to a summary of the results of exercise two. After finishing the three parts, there was a general discussion between participants and feedback sheets were completed. 


\section{Questions for exercise one}

-What are the methods available for user involvement in the design process?

-What are the potential advantages and disadvantages of using these methods in New Zealand primary schools?

-What are the methods that can improve communication between users and architects?

- How can teachers involve their students in classroom layout changes?

-What is the design experience of children in general?

\section{Questions for exercise two}

-What is the relationship between architectural borders (the shell) and the internal layout in the design process of learning environments?

-What is the architect's role in designing the internal layout of classrooms?

- How can architects create a flexible design that lets users change it easily according to their needs?

-How can the Ministry support felixble designs?

FIGURE 7-3: QUESTIONS ASKED DURING THE WORKSHOP

\subsubsection{PARTICIPANTS}

In general, it is recommended that focus group participants have something in common in order to make them feel as if they belong to the group (Liamputtong, 2011). The common things that all participants of the workshop shared were their support of user involvement in the learning environment design process, their passion for discussing the design process with others to enrich their knowledge and to gain experience for future designs, and their knowledge of the needs of learning environments.

The participants were architects who designed learning environments and teacher users of these. For the architects, 
invitation letters were sent to all architects' offices involved in educational designs in Wellington City. Only one architect replied positively to the invitation. Invitations also were sent to architects in the Ministry of Education, and one architect from the Ministry was planning to attend the workshop but eventually could not make it.

Students, although users of learning environments, did not participate in the workshop for several reasons, the main one being that young people need special research settings and ethical considerations. However, teachers at the workshop were primed to represent students, as they know student needs and how they might be involved in design. The teachers invited to the workshop were local primary school teachers. The invitation was sent to all primary schools in Wellington City. Five teachers attended the workshop. Thus, the participants of the workshop were six people and the researcher as facilitator.

\subsubsection{CONDUCTING AND ANALYSING THE} WORKSHOP

According to Department of health and Human Services (2008), a focus group needs a facilitator who guides the group through the planned discussions and keeps it focused on the desired topics, a note taker who notes everything said in the focus group, and a technician to record the event. In this workshop, the researcher was the facilitator. There was no note taker, as a voice recorder recorded all discussions, and notes were extracted from these later. The workshop did not 
need to be video recorded as it did not involve any physical actions, so a technician was also not needed. The focus group took three hours, including the introduction and a morning tea break. It took a place in a seminar room at Victoria University of Wellington.

In terms of analysing the data from the workshop, the stress should be on the interaction between participants more than on individual participants and the focus group planner. This gives the participants the opportunity to reveal points of agreement, clashes, and indecision better than with other methodologies, such as surveying and interviewing. This interaction gives an understanding of each participant's experience and views (Liamputtong, 2011). This was considered in the analysis in section 7.2.3.

\subsubsection{WORKSHOP FINDINGS}

In this section, the main findings from the workshop relevant to this research are discussed. The findings are divided into six sub-sections according to the workshop outline. The first five relate to the workshop structure and are postpresentation discussion, findings from exercise one, findings from exercise two, final general discussion, and participant feedback). The last sub-section discusses the findings from the first five subsections. 


\subsubsection{POST-PRESENTATION DISCUSSION}

As the presentation was mainly about encouraging more user participation, including participation by children, the comments revolve around the involvement of the latter in the design process.

The architect asked about involving one cohort of students in the design process when the design will have to be used for many future classes. The researcher explained that the ideas taken from children should not represent one cohort. The job of the architect is to modify the ideas to make them generally suitable. For example, if students suggest that they have a window of a certain size in one of the classroom walls, architects do not necessarily build this exact window in the final design. Instead, architects gain knowledge of what leads to this idea, which in this case is that children do care about having natural light inside the learning environment. Starting from this, it would then be possible to discuss how to create this with the children and why it might not be possible to create exactly the same idea as their suggestion (depending on the design conditions).

Teachers mentioned that involving children might lead to disappointing them if their ideas were not taken up in the design. The researcher provided information from the Ministry of Social Development (MSD) guidelines about involving children that show how to deal with these cases. The MSD guidelines recommend providing feedback to 
children about the process, as it makes them feel that their ideas have been taken and considered, and that some ideas have been changed for other reasons, such as the conditions of the process or the suitability of these ideas (Ministry of Social Development, 2003) (see section 3.3.1).

\subsubsection{EXERCISE ONE FINDINGS}

At the beginning participants started to talk about issues not directly related to the aim of the exercise, such as how students will feel about the new designs and how budget and time limit the designs, rather than how these design can be produced in a process that involves students and teachers. Some teachers just talked about their experience of teaching instead of talking about their experience of using and designing learning environments.

Consequently the discussion had to be re-directed to make participants talk more about the exercise. This was done through questions such as, "If you have a design project in your school, what would you like the communication between architects and users to be? What are the methods that can improve this communication?" After that, participants started to suggest some ideas and methods.

Discussion about this exercise fell into three categories: teachers' experience of working with their students in design work, suggestions on communication methods between students and architects, and suggestions on communication between teachers and architects. 
In terms of teachers' experience of working with children in designing learning environments, one teacher shared her students' experience of choosing new furniture for their classroom. She let them have a look at furniture websites but, as she said, they preferred their old chairs and desks. Another teacher shared her and her students' experience in changing the classroom layout. On the first day of school they put all the furniture in a corner. The teacher asked students to think about the design of their classroom. She provided students with sheets with the fixed features in the classroom, such as the walls, windows, and doors. The teachers said that the main problem was that students did not understand the concept of scale, so there was no way to apply what they suggested. She let them try by themselves, moving some furniture according to their suggestions, and they found that it did not work.

In terms of the communication between students and architects, some teachers suggested discussing the new designs with the students. One teacher suggested having learning sessions and activities that involve talking and discussing the new designs such as silent reading, group discussions, or talking to the whole class. He mentioned an example of how to make the designs part of learning. The example he gave was sitting in the sun to read a book can cause overheating and then children will be distracted. At the same time, they need some light to work. This example will 
teach students aspects of natural lighting and dealing with overheating.

Teachers suggested that the communication between architects and students could be through teachers. Architects can provide the main ideas and aspects of the design, and then the teachers can discuss these issues with students to gauge their opinions and comments. Other teachers said that architects need to communicate with students directly, as if teachers are the link between students and architects their ideas and thoughts will affect the communication and some of the children's ideas may not be delivered to architects as they should be. The communication could be through a workshop where children draw or discuss issues about the design and the architect comes and interacts and talks with them about what they are doing. Another suggested method is taking the children to visit different local learning environments (including good and bad spaces), discussing what they have seen, and then allowing them to suggest ideas for their own learning environments.

Participants discussed how children have knowledge about designing spaces, as some of them would have been involved in designing their own bedrooms in their houses. Children may know the basics of designing spaces, such as a good location for the window or the door.

In terms of the communication between architects and teachers, only one teacher mentioned it during this exercise. She suggested that the architect could show teachers 
examples and visual presentations about the new designs. Sometimes teachers understand something and agree on it and then after construction, they find it is different from what they understood would happen.

\subsubsection{EXERCISE TWO FINDINGS}

The exercise was introduced by presenting some students' drawings from the phase two blog posts. This created a discussion about the relationship between the architectural elements and the internal classroom layout.

The main issue that arose in the discussion is that the relationship between the borders of any classroom and its internal layout depends on how flexible the classroom is. Movable walls can change the shape of the architectural borders and affect the furniture layout. Some furniture can affect the architectural elements, such as using bookshelves and dividers inside a room. One large classroom can be divided into corners or zones for specific activities without the need of any dividers. Using colours and materials can help in indicating the different zones.

The participants discussed some of the Ministry of Education recommendations for new designs, such as having a cave area for private learning, water-hole area for small group learning, and campfire area for teaching and learning in large groups. The architect said that the Ministry requires these areas to be designed in by architects, while he thinks that these areas should be created by occupation. The architect suggests and 
thinks that the best way of letting users determine the design of their classroom is to design a room with sliding doors, where another space can be partially or entirely closed off, but where these are not fixed. Every classroom needs some small spaces where users can shut the door and be separated from the rest of the class. One teacher said that the shell may limit the potential of the internal space.

The discussion then aimed to figure out how to create these flexible spaces and movable walls that can create smaller spaces within the classroom. One teacher suggested having large settings such as a large storage unit that cannot be moved easily but can move to divide spaces (Figure 7-4). He said that the problem of having sliding doors as dividers is that they are fixed so they cannot be moved around the classroom. The architect commented on this idea, stating that architects do not have the budget for furniture, which is given directly to the school. So the architects cannot suggest any designs that depend on choosing furniture. The architect suggested designing some architectural elements that can work as furniture and dividers. He suggested designing big lockers that can be justified as an architectural element but that are still mobile enough to work as dividers inside the classroom (Figure 7-5). He also suggested having big partitions that can swing around to create a divider and still can be used for display. When they are open you can move through them (Figure 7-6). They allow for continuity between 
spaces and at the same time provide borders for a separated space if needed.

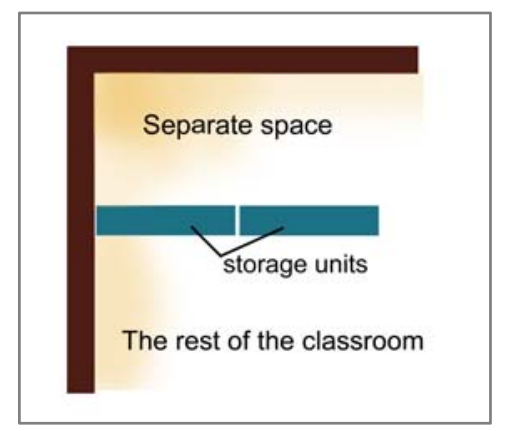

FIGURE 7-4: A TEACHER'S SUGGESTION FOR CREATING A DIVIDER WITH STORAGE UNITS

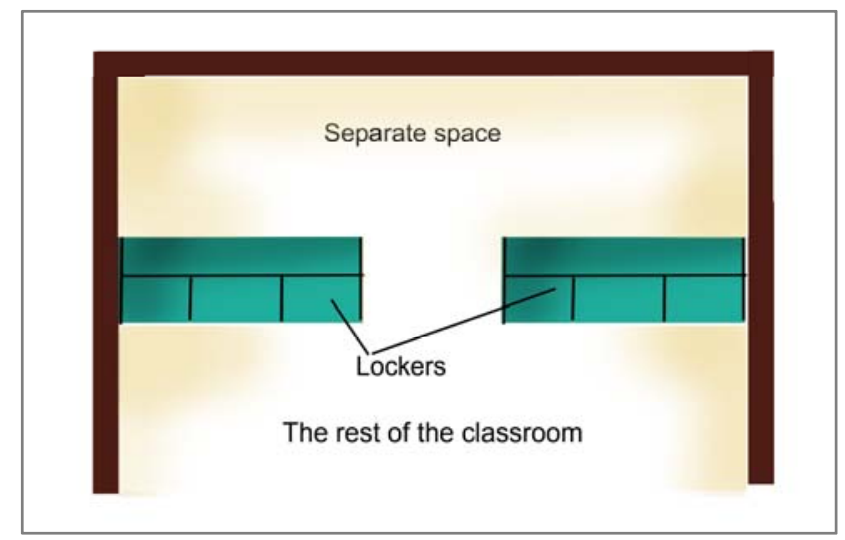

FIGURE 7-5: THE ARCHITECT'S SUGGESTION FOR CREATING A DIVIDER WITH LOCKERS 

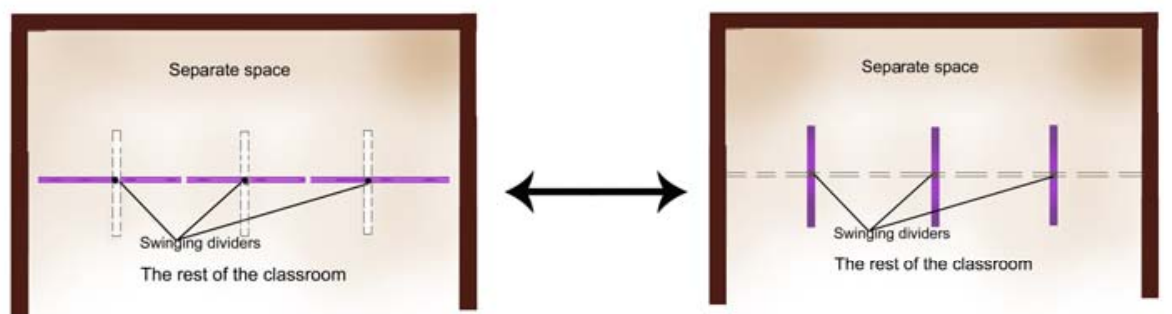

FIGURE 7-6: THE ARCHITECT'S SUGGESTION FOR CREATING

ROTATABLE PARTITIONS

Participants said that these dividers will not necessarily work to create a separate classroom, although depending on the location of the divider, it could be used to create a small space for activities such as private thinking or one-to-one teaching. They also discussed that in some situations, these dividers are not used. They are either opened, creating an open plan classroom, or closed to create separated single cell classrooms. Participants claim that this depends on the strategies and pedagogy of each school.

A teacher suggested having flexible furniture in additional to flexible spaces, such as foldable chairs or tables that can be folded and stored easily.

The researcher suggested an idea for creating a flexible classroom where users can manage the shape of the space by themselves and asked participants about the advantages and disadvantages of such an idea. The idea, inspired by a dots and boxes game, is to have a large open space and a number of partitions or small dividers that can create corners and 
rooms inside the big space (Figure 7-7). Different teachers and students can create different shells according to their preferences and learning styles. The disadvantages of having this space are that it could be difficult for teachers and students to operate and that teachers could have it in the same arrangement every year, claiming that it worked for the previous year. The advantages are that the children will think more about the environment they are using and this will affect their learning, through having flexible space for different teaching needs. 

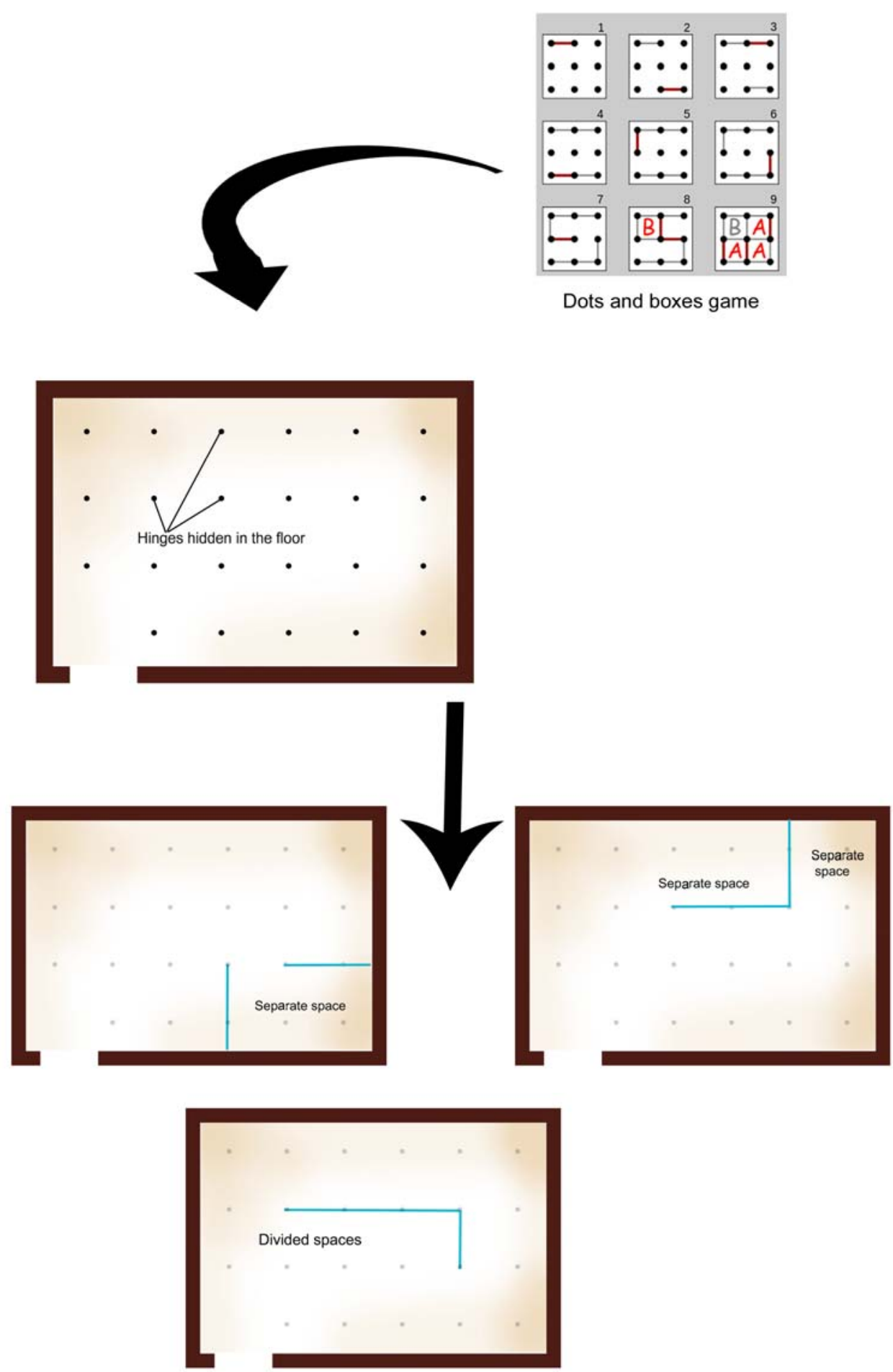


\subsubsection{FINAL DISCUSSION}

In the final discussion, participants talked about the role of the Ministry of Education in supporting and facilitating communication between architects and users of learning environments, with the main points brought up summarised below.

The Ministry of Education is the client for many educational projects, so the Ministry needs to build up a body of experience and knowledge around the communication between users and architects during the design process. They need to provide the basics of a participatory design process. Examples and case studies of recent successful learning environments in New Zealand should be provided. The examples provided on the Ministry website are dated and most of them are not really good designs. The Ministry guidelines do not provide information about important issues that affect the design and the design process, such as information about involving students or information about types of learning environments that can be considered in the schools. They recommend visiting online websites of international architects who talk and give examples of modern learning environments, such as the website of

${ }^{1}$ The dots and boxes photo is from http://en.wikipedia.org/wiki/Dots and Boxes 
Fielding Nair International (2014), although the group acknowledged that what appears on these websites might not be suitable for New Zealand learning environments. The Ministry, as a keeper of the standards, should provide enough resources about New Zealand learning environments, especially as the architect may not have the time or budget to research and collect the right resources for each project. Architects are normally very competitive, which makes them reluctant to share their experiences and knowledge about learning environments. Thus, they sometimes have to start from scratch in educational projects.

\subsubsection{FEEDBACK}

The feedback questions were about the new knowledge that participants gained from the workshop, the changes that participants will consider after attending it, and ways for better communication between users and architects (see appendix F).

The new knowledge for teachers included understanding the process of designing new and modern learning environments; knowing about the Ministry guidelines and resources; knowing of a new process for gathering the student voice by providing models, visiting schools, direct interaction with architects, and focus groups; and ideas about changing the internal layouts.

The workshop has given teachers some new ideas, such as exploring space usability within modern learning environments, investigating the school websites that were 
mentioned in the workshop to look at the architecture and indoor spaces of these schools, trying to strengthen the consultation process between users and architects for their design projects, and observing a range of schools (playgrounds, classrooms, and staff rooms) in order to widen their ideas about modern learning environments.

One teacher said that collaboration is important for the design of learning environments, whether it is face to face or through experience. Another teacher complained about the time limit that teachers have, so workshops are preferred that are on a specific project or need instead of having them for general communication. A teacher said that it would be great if an experienced architect came to the school and met the staff and listened to their thoughts. A teacher suggested that teachers need to gain confidence with the design of learning environments in order to have more effective communication with architects. One teacher suggested that the Ministry could develop a bank of ideas and case studies so teachers are enabled to assess a design process in schools.

The architect liked talking with teachers about how they think about issues of consultation. He said that the workshop provided him with some information on how to consult teachers and increased knowledge of potential changes to learning environments. The architect also supports having workshops or any type of communication with teachers, as 
the latter enhances the architectural work of designing learning environments.

Teachers liked having an architect to talk with in this workshop. Others, including the architect, wished that the person from the Ministry of Education had managed to attend.

\subsubsection{DISCUSSIONS ON THE FINDINGS OF THE WORKSHOP}

The main thing discussed after the presentation concerned involving a certain group of children in a design that may then exist for long time. This is mentioned many times in this $\mathrm{PhD}$ research in different case studies by different people (see section 7.3.4.1, 7.3.4.5 \& 7.3.4.6). It may indicate that thinking this makes it easier not to involve children than involve them and deal with the circumstances of this involvement. Involving children may need extra research about how to work with children, what to do about ethics approval, and how to create the extra time spent with these children, in addition to claims about potentially disappointing children. But are these reasons enough to ignore the vital role of children's participation in the design process?

In terms of the first exercise, from the researcher's observations, teachers did not have enough knowledge about design and the design process. Consequently, at the beginning of exercise one they talked about different issues not related to the exercise. However, when they were directed to the point of the exercise they suggested some interesting 
ideas. Although the exercise is about the users of learning environments, including teachers and students, participants focused on the communication between architects and children and did not discuss their communication with architects at the same level. Participants may find that discussing communication with children is more important than the communication between adults, as children need special methods and treatments. Teachers might have discussed communication with children more than other issues because they feel that the lack of communication between architect and child is greater than that between teachers and architects.

In regard to the second exercise, the relationship between the shell and the internal layout is problematic, as architects do not have any say in choosing the furniture, which may shape the internal layout, and the users are not designing the shell, which also can affect the internal layout. Having flexible spaces can work or not, depending on the will of the users. For example, where moveable dividers are provided teachers may leave them closed for the whole year and not make use of the possibility of having an open plan layout. What, then, should be done to make sure that the flexible spaces are used as they were designed?

The main issue to emerge from the final discussion in the workshop is that the Ministry should provide the knowledge and resources for architects and schools to enable better 
communication. This might go some way to answering the question about flexible classrooms, as having a series of case studies of such classrooms in use in different formations over a school term or whole year would show the possibilities. This information could be supplemented by how long it took to change the classroom formations, and what the children thought about the changes. The Ministry could also be the medium that supports and works on the communication between involved parties, whether by working directly in encouraging more communication or by providing the resources that would enable the parties to work on the involvement themselves. The role of the Ministry is very important, as in some cases schools lack knowledge about designing learning environments and architects may lack knowledge about involving users in the design process.

In terms of the feedback, teachers have gained new knowledge and developed a desire to know about the design of learning environments and to communicate more with architects in any design process in their schools. Having a communication session such as this workshop can develop teachers' knowledge about design and the design process of learning environments. However, due to the limited time that teachers have, it is difficult to conduct general communication sessions. Participants wanted to have someone from the Ministry in the workshop, which may indicate that they see the Ministry of Education as responsible for the communication between users and architects. The Ministry 
could facilitate this through building the right medium for all parties to have effective communication.

\subsubsection{THE WORKSHOP: CONCLUSIONS}

The main results of the workshop are that participants found student involvement in the design process to be a difficult issue that needed time and experience to be completed successfully. Participants focused on how students could be involved in a design process and did not talk enough about teacher involvement. The architects having no say in choosing the furniture for the schools they work on and having so many parties involved in the design process also emerged as problems. Communication throughout the design process is also usually weak. It was also felt that the Ministry should study and work on the design process of learning environments to provide good resources for architects and schools to use when they have a design project.

Overall, the workshop did not result in new ideas for user involvement in the design process. Instead, problems that may occur in any design process were discussed. These included problems with involving students and the relationship between the parties involved in the design process.

\subsection{PhASE FOUR: CASE STUDY}

Phase four is a case study on the involvement of users in the design process of learning environments. The Thorndon 
School, Wellington, rebuilding project is the focus of this phase.

\subsubsection{THE AIM OF THE PHASE FOUR CASE STUDY}

Apart from this research, a number of primary schools in Wellington were visited whilst writing the thesis for the personal reason of enrolling a child in primary school. During the visits the design of the classrooms and learning environments was obviously a focus. Thorndon School in Wellington City was one of the visited schools. During the visit the principal talked about a project that they were working on to rebuild some of the school blocks. The principal also mentioned the school was planning to involve the school users in the design process in a collaborative manner. As part of this research is examining the relationship between users and architects in the design process, the Thorndon school project became a case study for this. So the aim of this case study was to observe the roles of teachers and students in the design process related to the rebuilding project.

Because of the time limits for this study, this phase only covered an initial part of the design process for the whole rebuilding project.

\subsubsection{BACKGROUND TO THORNDON SCHOOL}

Thorndon School was established in 1852 in the inner city area of Wellington, New Zealand. There have been many changes since it was established but only the more recent ones are described below. 
In 1992, an adventure playground was built and in 2006 and 2007, it was redeveloped and renovated. In 1997, the computers in the school were all linked to each other and to the library and administration by a network. This network was replaced in 2007 by a new Wi-Fi network. In 1999, a hall was donated to the school and was located in the school's grassed field. The hall has since been renovated and in 2005 a kitchen and toilets were added to it. In 2000, two new classrooms were built in addition to an administration area. During 2003, the school library was extended and renovated. In 2005, another classroom was built and a number of old classrooms were renovated. In 2012, an old block in the school was converted to a classroom (the original function of the block was not specified) (Thorndon School, 2014).

Before the rebuilding project, the school site consisted of two grassed playing areas and a sealed netball/basketball court. The school has 12 classrooms, a library, a hall, an art room and a music room, in addition to other facilities and offices (Thorndon School, 2014).

\subsubsection{METHOdS USED FOR THIS CASE STUDY}

The methodology used in this case study is based on that of Yin (1994), which is used in case studies where the question starts with 'how' or 'why' and when the researcher has no control over the events of a current case study. A pilot study was not conducted, as there was only one case study available, so the pilot was the same as the case study. 
For any case study, certain information should be provided, including the question behind the study, the study proposition, units of analysis, how data is to be collected and how the findings are to be analysed.

In terms of the study question, this study was conducted to find out what happens in a normal learning environment design process in New Zealand, so the question is: What is the communication between users and architects in a learning environment design process in New Zealand?

In terms of the study proposition, based on the information concluded from chapter 4 (see section 4.4), which confirms that the Ministry supports this communication and given there are ideal design examples that involve the users in the design process, the proposition is that the communication between users and architects is very strong and that this communication will affect the final designs of the project.

In terms of the units of analysis, these are the people involved in the design process as provided by the principal of the school:

- Ministry of Education: They run and fund the building contract. They set the financial and physical parameters. The principal said that the Ministry is the client and they are consulted about the project. The principal has direct contact with a person from the property team in the relevant Ministry department in Auckland. The Ministry assessed the project in terms 
of the budget needed for it. There was contact with another person from the Ministry located in Hutt City, Wellington. The principal said it did not matter whether the people from the Ministry, who assess the project, were in Wellington or from another city, as they come regularly to the school.

- Project Managers: They run the project for the Ministry. They commissioned the architect to carry out the Master Planning exercise, which was completed in December 2013. They will commission the building contractors.

- Architects: They design the project. The architect's team has three members in addition to the landscape architect, an engineer, a geoscience expert, and a quantity surveyor, who meet with the school when needed.

- The school: In some respects the school is also a client, as the school is contributing some 5 years of their building budget to the project. However, they only have a consultative role. The school has a property team who will work together on the project. The property team consists of members of Board of the Trustees (BoT), the principal, and the project manager for the school.

As the aim is to study the communication between users and architects, this study focused on the school, including teachers and students, and the architects for the project.

According to Yin (1994), the case study methodology has six possible sources of evidence: documentation, archival records, interviews, direct observation, participant 
observation, and physical artefacts and a good case study uses as many sources as possible. This case study came up during the course of the thesis and the aim here is to observe what happened and what was described as a collaborative design process. As a result, the methods used for collecting data for phase four of the research depended on how the process went, but included documentation, interviews (including focus groups), and participant observation.

\subsubsection{Documentation}

The documentation is represented by the master plan provided by the principal of Thorndon School and the basic information about the school from the school website.

\subsubsection{INTERVIEWS}

A number of meetings and interviews were held, including meetings with the principal, teachers, and the architects. The interviews, meetings, and focus groups were designed to gather information from participants about the collaborative design process with which they were involved. Interviews included face-to-face interviews and interviews via email.

\subsubsection{PARTICIPANT OBSERVATION}

The main observers were the principal of the school and the researcher. The principal observed the reactions of students and teachers towards the collaborative project he conducted and communicated findings to the researcher, while the researcher observed the communication between all the parties during the focus groups and meetings. 
In terms of analysing the data, this is done according to the proposition mentioned earlier. All the meetings and observations are analysed in terms of whether the involvement of students and teachers affects the final designs. Each of the meetings and observations are discussed and analysed separately below. At the end of this section general discussions and conclusions about this case study are presented.

\subsubsection{FINDINGS AND DISCUSSIONS}

As discussed in the methods used for this case study, there were a series of interviews and visits to the schools to collect the information needed. The findings are divided into seven small sections that reflect each interview, meeting, or document. Findings are presented in the same order the interviews were held. Each finding is followed by a small discussion in terms of the aim of the case study: finding out the level of user involvement in the design process.

\subsubsection{FIRST MEETING WITH THE PRINCIPAL}

The findings from the first meeting are in three parts. The first concerns the principal's opinions about the design of learning environments, the second was about user involvement in the design process, and the third was a discussion of the timetable for the project.

This meeting was a semi-structured interview with only the school principal. The principal commented on the design process and his view of learning environments. The principal 
thought that the biggest change in the new project for teachers would be the de-privatization of the learning environments, as before the project teachers had single cell classrooms. With the new designs there would be a continuum of learning spaces. At one end of this continuum each teacher would have his or her own single-cell classroom, while at the other end the school would have classes of 80 students with 3 teachers for each class. At the time of the meeting, the principal did not have a vision of what the design outcome could be in terms of the types of learning space. The principal's opinion of having flexible classrooms that could be single-cell or open plan depending on movable walls was that these classrooms, from what he has seen in the schools he had visited, were either used as single cell classrooms or open plan classrooms. He said that installing movable walls was quite expensive, so he felt it was better to spend the money on something that was going to be used. He said that with the new acoustics technology, private and quiet spaces can be created within the open plan style classroom. The principal talked about having flexible furniture pieces instead of flexible classrooms. For example, with the technology, schools can provide movable whiteboards and data projectors to create movable interactive whiteboards that can be used anywhere inside the learning area, instead of the fixed interactive whiteboards that make learners use the space in just one way.

The principal argued that hearing the voice of teachers during the design process is important. Getting the voice of students 
is also important. In terms of the student input, the school was planning an inquiry based on the question, "What would you like your future classroom to be like?" However, there was resistance from some teachers who had participated with their students in designing playgrounds and then found that what the students wanted was not incorporated into the final designs, which was disappointing for both teachers and students. The actual reasons for not incorporating the students' ideas in that project were not known, as the project was completed a long time ago under another principal.

The principal said that teachers need to be encouraged more to involve their students in the design process.

The researcher suggested a method inspired by an American teacher who involved her students in a project where they designed a method for how to get ideas about their existing school environments. The students suggested having a board of photographs in each school zone that represented the main elements in that zone. They asked other students, staff and the community to comment on these elements as to whether they liked them or not, or what could be changed and to put the comments in a suggestion box in front of each zone. The main result of using that method is that the school gathered a huge number of comments that could help them in improving the school environments. The principal liked the method used in the US school and planned to replicate it in Thorndon School, starting with the library zone. 
The principal discussed the different stages of the design process that were completed before this first meeting and other stages that were expected to happen later. Table 7-1 sets out these stages with brief information about each.

TABLE 7-1: THE DESIGN PROCESS UP TO THE TIME OF THE MEETING WITH THE PRINCIPAL

\begin{tabular}{|l|l|l|}
\hline Actions & Details & Time \\
\hline $\begin{array}{l}\text { Research } \\
\text { before } \\
\text { starting the } \\
\text { project }\end{array}$ & $\begin{array}{l}\text { The principal did some personal research when } \\
\text { he knew that the school would be involved in the } \\
\text { new project. He read about designing learning } \\
\text { environments in a number of books. }\end{array}$ & Early 2013 \\
\hline $\begin{array}{l}\text { Choosing the } \\
\text { architects for } \\
\text { the project }\end{array}$ & $\begin{array}{l}\text { At first the Ministry put the project out to tender. } \\
\text { They showed the school to six different architects, } \\
\text { with an outline of a proposal for the project. } \\
\text { Three of the architects gave presentations to the } \\
\text { school board, the principal, and the project } \\
\text { manager. At that point the Ministry and the } \\
\text { school decided on the architects for the project. }\end{array}$ & Early 2013 \\
\hline Proposal \\
presentation & $\begin{array}{l}\text { Architects held several proposal presentations, } \\
\text { which were the start of the school working with } \\
\text { the architects. Then the Ministry appointed one } \\
\text { architecture firm for this project. } \\
\text { No brief was provided from the school to the } \\
\text { architects. Instead, there were meetings and } \\
\text { discussions about the project. }\end{array}$ & July 2013. \\
\hline
\end{tabular}




\begin{tabular}{|c|c|c|}
\hline Actions & Details & Time \\
\hline Meetings & $\begin{array}{l}\text { The meetings to date have ranged from one-to- } \\
\text { one meetings to larger consultation meetings. } \\
\text { There have been approximately eight meetings } \\
\text { up to the time of collecting this information. } \\
\text { Three of them involved teachers. The meetings } \\
\text { ranged from those with just the architects and } \\
\text { principal to meetings that involve the architect, } \\
\text { the project manager, BoT members, and staff } \\
\text { representatives to meetings that include } \\
\text { community representatives, BoT representatives, } \\
\text { Ministry of Education, and project manager to } \\
\text { meetings of just staff and the architect. } \\
\text { Staff meetings without the architects. } \\
\text { There are also staff representatives that take the } \\
\text { with the architects. } \\
\text { Meetings that involved teachers of Thorndon } \\
\text { Meetings: } \\
\text { Meetings that involved the principal, architect, } \\
\text { and the staff of the visited schools. These } \\
\text { included presentations and questions about the } \\
\text { desing and deliver it to the meetings } \\
\text { Sch schools. }\end{array}$ & $\begin{array}{l}\text { During } \\
\text { the whole } \\
\text { design } \\
\text { process }\end{array}$ \\
\hline
\end{tabular}




\begin{tabular}{|c|c|c|}
\hline Actions & Details & Time \\
\hline School visits & $\begin{array}{l}\text { They have visited } 3 \text { schools in Auckland and } 2 \text { in } \\
\text { Wellington. } \\
\text { The principal organized for one of the school } \\
\text { board members to accompany him. They also } \\
\text { invited the architect to go with them. A team of } 3 \\
\text { architects went to the school with the principal } \\
\text { and the member of BoT. } \\
\text { The three high decile schools they visited in } \\
\text { Auckland are: } \\
\text { - Stonefields School } \\
\text { - Hobsonville Point Primary School } \\
\text { - Hingaia Peninsula School } \\
\text { with a transition board. The staff was then hired } \\
\text { These schools are different from Thorndon } \\
\text { In Wellington, the principal and the staff visited: } \\
\text { - Amesbury School twice (high decile school) } \\
\text { - Kahurangi School (low decile school) } \\
\text { that they are new schools and the Ministry had } \\
\text { already arranged visits to see these schools in } \\
\text { Auckland, but as the principal could not take part }\end{array}$ & $\begin{array}{l}\text { During } \\
2013\end{array}$ \\
\hline
\end{tabular}




\begin{tabular}{|c|c|c|}
\hline Actions & Details & Time \\
\hline & $\begin{array}{l}\text { on the basis of the philosophy of the school, } \\
\text { whereas Thorndon School already has its staff, } \\
\text { students, and philosophy. }\end{array}$ & \\
\hline Master plan & $\begin{array}{l}\text { The architect interviewed the principal on how } \\
\text { the school was run. The fact that the school used } \\
\text { to be run on the basis of a team of three classes } \\
\text { was at the centre of the new designs. }\end{array}$ & $\begin{array}{l}\text { December } \\
2013\end{array}$ \\
\hline $\begin{array}{l}\text { Ministry } \\
\text { approval of } \\
\text { the master } \\
\text { plan }\end{array}$ & $\begin{array}{l}\text { The principal was expecting to have approval } \\
\text { from the Ministry by February 2014; however, the } \\
\text { approval was not received when the researcher } \\
\text { met the principal for the last time on } 12 \\
\text { September } 2014 \text {. }\end{array}$ & $\begin{array}{l}\text { Not yet } \\
\text { received }\end{array}$ \\
\hline $\begin{array}{l}\text { Detailed } \\
\text { plans }\end{array}$ & Prepared after the Ministry approval is given & $\begin{array}{l}\text { There is } \\
\text { no } \\
\text { estimated } \\
\text { time for } \\
\text { these }\end{array}$ \\
\hline $\begin{array}{l}\text { Teachers' } \\
\text { voice }\end{array}$ & $\begin{array}{l}\text { They have a Google drive where teachers can } \\
\text { share their opinions during the design process. }\end{array}$ & $\begin{array}{l}\text { During } \\
\text { the whole } \\
\text { design } \\
\text { process }\end{array}$ \\
\hline $\begin{array}{l}\text { The } \\
\text { construction } \\
\text { stage }\end{array}$ & $\begin{array}{l}\text { The construction was planned to start in July } 2014 \\
\text { but the dates have changed because of the delay } \\
\text { in gaining the Ministry approval. There was no }\end{array}$ & $\begin{array}{l}\text { Not yet } \\
\text { decided. }\end{array}$ \\
\hline
\end{tabular}




\begin{tabular}{|l|l|l|}
\hline Actions & Details & Time \\
\hline & $\begin{array}{l}\text { selected date for the start of the delayed } \\
\text { expecting the construction to start in } 2015 .\end{array}$ & \\
\hline
\end{tabular}

\subsubsection{THE MASTER PLAN}

The master plan is a document that was analysed for this case study. The document was provided privately by the school principal.

By 12 December 2013 the master plan had been completed by the architects, with consultation with the principal, board of trustees, staff, project manager, and community of Thorndon School. The master plan was then submitted to the Ministry of Education for approval. It is a plan for the next 30 years of development.

The master plan consists of a set of information about the situation of the existing buildings, site characteristics, and design intent. In terms of the existing buildings, the building stock is varied in age, style, material, and functionality. The site consists of a large number of public entries that are used by both the general public and school users. This creates unconnected outdoor areas and buildings that relate to each other ineffectively. Most of the learning spaces are varied, of poor quality and provide less than the required contemporary learning environments. 
The new project, which was assigned in early September 2013, includes replacing 8 classrooms and the school's existing administration block due to weather-tightness issues. The master plan aims to create a clear occupation for the site with an efficient use of the space, design pathways that link the buildings on the site with clear entries for public and school users, and create environments for maximum learning.

In terms of redesigning the learning environments (classrooms), the master plan discusses one of the existing classroom blocks and that the classrooms there are single cell classrooms without any connection with each other. The suggestion is that this block be converted to an administration and library block due to its location.

In general, the plan is to design learning environments with maximum sun and light for indoor areas and create quality outdoor learning areas. The learning area should be allocated around the heart of the school, which is the central playground and associated outdoor learning areas. The master plan does not mention any details about the designs of the learning environments and their internal layouts. The master plan contains details of problems in the existing buildings and how these can be solved with the new projects. Figures 7-8, 7-9 and 7-10 show the master plan for the rebuilding project of Thorndon School. 


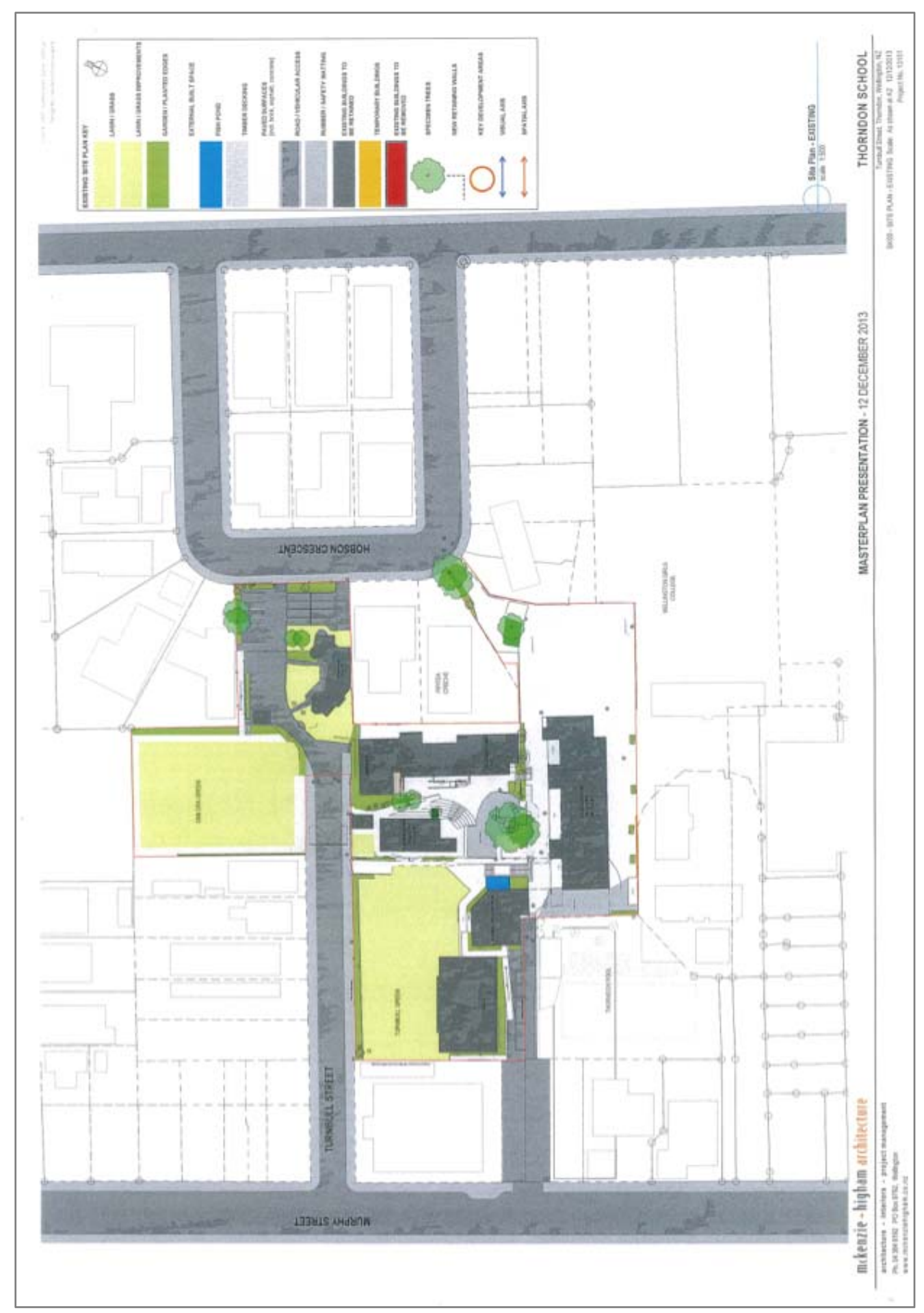

Figure 7-8: EXISTING SITE PLAN OF ThORNDON SCHOOL: Provided By Mackenzie and Higham Architecture 


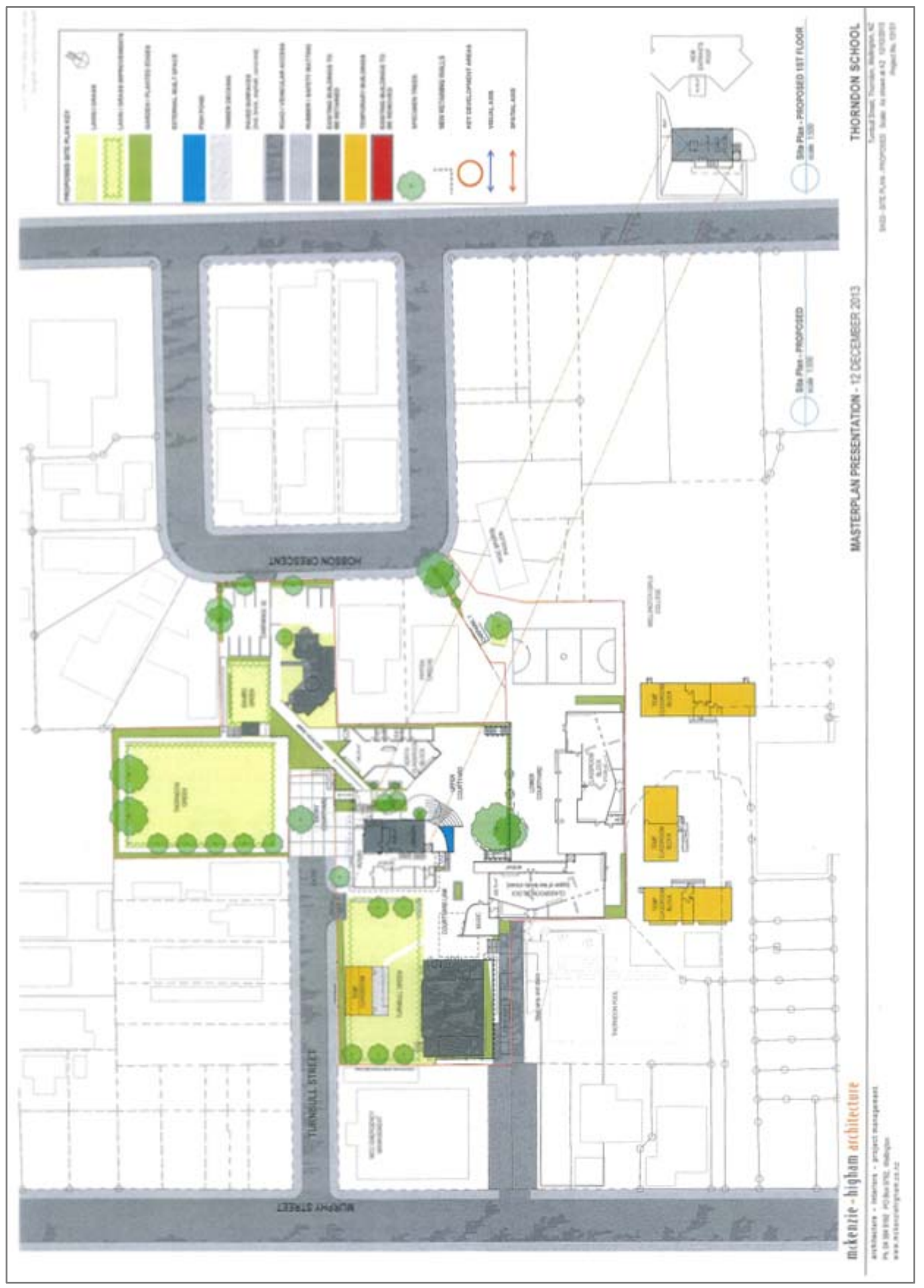

Figure 7-9 Proposed SITE PLAN OF THORNDON SCHOOL:

Provided by Mackenzie and Higham Architecture 


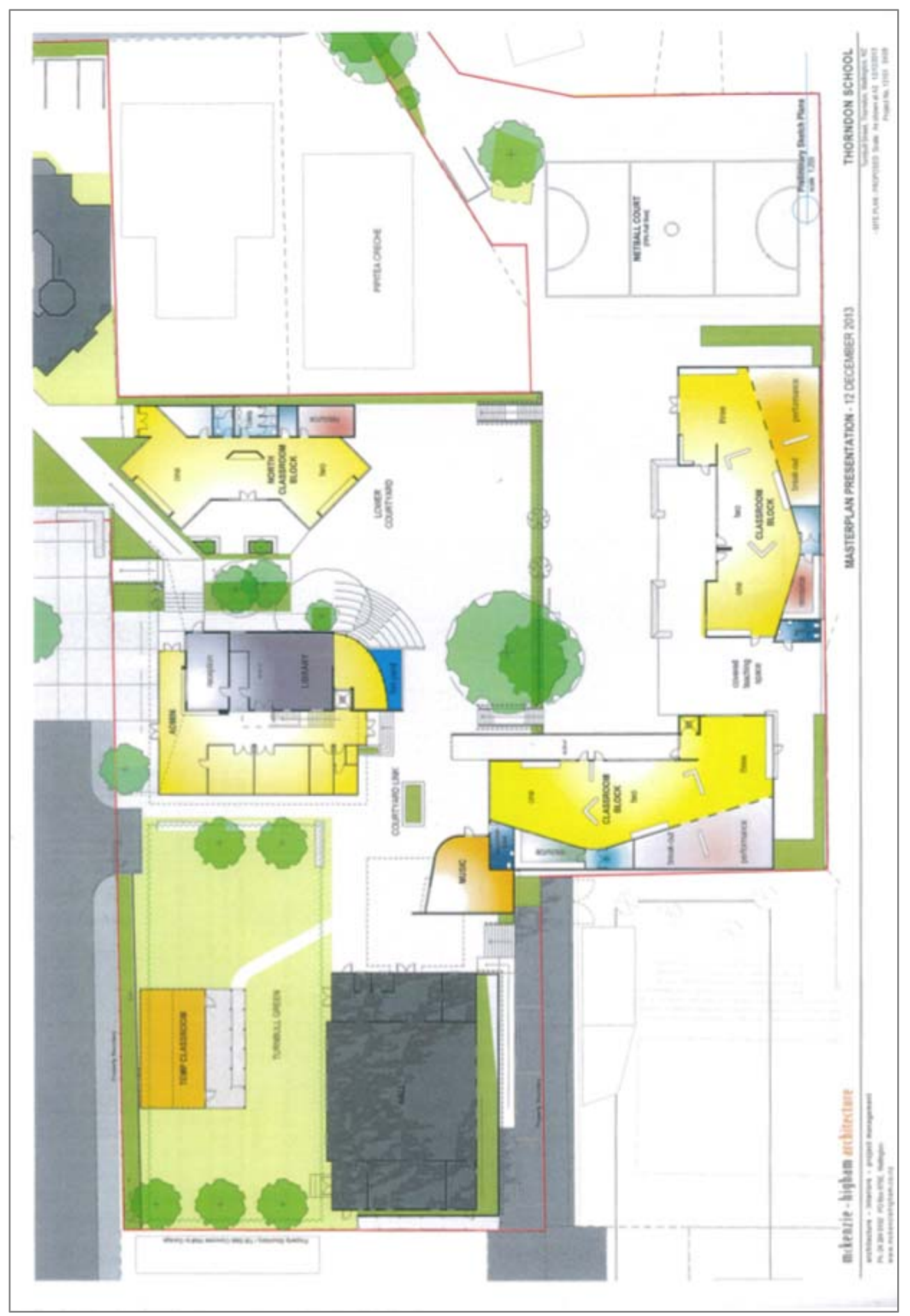

Figure 7-10: Proposed floor Plan OF THORNDON SCHOOL. Provided by Mackenzie and Higham Architecture 


\subsubsection{USING SOCIAL MEDIA: THORNDON SCHOOL REDEVELOPMENT CONSUlTATION DOCUMENT ON GOOGLE DRIVE}

The school has created a social media site using Google Drive for school staff to share comments about the new project during the design process. It contains comments from the community but these are as reported by the principal or one of the staff, as community members do not have access to the Google Drive file. It was accessed for this research and is described and discussed below. A reference cannot be provided for this document, as it is a private document.

In terms of the community voice, the comments include questions about a presentation where the project was shown to the local community, comments about the entries to the school and the location of toilets in relation to some classrooms, and other issues with the site plan.

In terms of the teachers' voice, the comments included issues around the existing buildings, problems teachers face using the facilities of the existing buildings, some suggestions for change such as changing the old toilets, and their reflection on the visits to the two schools in Wellington in terms of what they liked and did not like.

On the social media site, participants can add comments at any time. The comments change, depending on the phase of the design process. There is no access to the old comments, however. 
The Google doc has all the posts on one page. All posts are saved after each entry. There are no categories, photographs or diagrams provided. There is also no option to comment on other comments or reply to posts. Google doc is shared only by professionals such as teachers, the principal, the architect and the researcher (as mentioned, no community members have access). The fact that there is no student or community voice may indicate that the principal either does not care about these or is unsure of the worth of including them. However, this situation may only apply to this stage of the project. In addition, there have been no meetings with students about the project.

Another document was created in Google to discuss comments from the display of the music room project at another stage in the process. This will be discussed later, when talking about the display project.

\subsubsection{FIRST MEETING WITH STAFF AND PRINCIPAL}

In terms of the level of teacher involvement, the principal has shared some of the drawings of the new project with them, in addition to other different plans. Some teachers have visited schools with the principal. They have also had the chance to post comments and suggestions through Google doc.

The teachers reported they found Google doc a good place to share their comments, claiming this was the easiest way for teacher involvement, given the time it can save. They also commented on the fact there was no feedback to their 
comments in Google doc. The principal said, however, that he and the architect were waiting for the Ministry to approve the master plan and the scope of design, after which they would give feedback on the teacher comments.

When the absence of photographs and diagrams in the Google drive was mentioned by the researcher, the teachers admitted that it is was quite difficult not having these, as they would forget what they had seen in the meetings or presentations, which made it hard for them when it came to making comments. The principal had claimed that they could not publish the floor plans before the Ministry approval of the master plan.

In terms of teacher responses to not being able to comment on other comments, the principal said that they started using the Google doc for the teachers' voice rather than other social media because they use Google drive in their work at school. So they thought it would be easier to use the same social media site with which everybody is familiar. One teacher said that they had not thought about criticising or commenting on the thoughts of others, but just wanted a place to post their own thoughts.

The teachers felt it was better to have just the teachers' voice in the doc, without sharing it with the community and students' parents, as some opinions could be taken out of context. The principal said that they had only had one community consultation and it was not an open community 
meeting, as it was just for members from the BoT and a few community representatives.

The teachers said that students were not yet involved in their discussions and thoughts about the new project. However, one teacher said that he had talked with his students about problems regarding the school toilets but he also said that this could just be a waste of time, as there might be changes to the final master plan. The principal said that they might need to start more community consultation when the process starts after the Ministry approval, as the project might then proceed very quickly. Even if this is not facilitated by the project manager, the principal said that they could do it themselves, as when the project manager was planning a timeline for the project it would be possible to put in a week or so for community consultation, although it was felt that one week would probably not be enough.

The researcher suggested having a focus group with just the teachers to discuss the design process in more detail, especially teacher and student involvement. The teachers agreed to this, with the idea of discussing more ideas and thoughts about the new project, whether at the scale of the whole school or the scale of one learning environment or classroom.

The principal suggested that a representative teacher from each year level group attend the focus group and then go back their group to discuss the ideas with other members. 
The principal was asked whether the new designs would be influenced by the teacher discussions and thoughts. He said that the overall plan was for 30 years and when the final alterations are finished the teachers will be different people, so the designs would not reflect their ideas.

\subsubsection{FOCUS GROUP WITH TEACHERS}

The focus group was a semi-structured discussion with the teachers of Thorndon School, who are representatives from each year group, in order to discuss ways that users (teachers and students) can somehow be involved in the design process.

Teachers were asked questions such as: "How do teachers feel about the fact that the principal may not consider all teachers' and students' comments, as teachers might and students will be different in the future? Is this just an excuse not to involve everybody?"; "How do teachers feel about the fact that they can be involved in the internal layout of the learning environments even though they were not involved in designing the buildings?" This was done to initiate a discussion on participatory design.

In this meeting teachers were clear that their voice should not be ignored and they should be involved in the design process. The outcome should be something that corresponds with their desires. Thus, for them, consultation is very important.

The teachers acknowledged that there would always be people who disagreed or had different views of some ideas, 
but "kids are kids" and teachers design their learning spaces to be suitable for children. They also do not know what education will be like in 30 years. Thus teachers' ideas may not suit the education in the future but it will still serve the children, as teachers' ideas are all about the students and what suits them.

The teachers also felt that the process is very difficult for them. The biggest problem for the teachers is that a lot of them have not been involved in any rebuilding project before, and they do not know what the process should be like. They had been informed of the process, so when they were consulted they gathered ideas "urgently" for the new design, only to discover it was already planned. They felt that this was not a good way to involve teachers in the process.

However, they did think that they might be involved more, and their ideas even incorporated in the designs, at the stage of designing the details of the building, especially the layout of learning environments. They said that it had been quite a big discovery to find they would be group teaching. They were not involved in any discussion about the group teaching idea, but were just informed this was to happen. One teacher said that she thought this was the ideal way for modern learning and the school was heading toward this direction, and teachers would either adjust the way they teach or find somewhere else to work. Another teacher had tried group teaching before, teaching individually in separate classes but in the same big classroom or class area. Sometimes, she said, 
one of the classes got disrupted because of the activities of the other classes. Teachers thought that group teaching would depend on the personalities of the teachers and whether and how well they could work in teams. The teachers said that they had discussed the new teaching strategy with other teachers and thought about ways of working together in the same big space, and were hoping the new design would work well.

The teachers felt they would not have any voice in designing the architectural part of the school, as this would be the architect's job. They thought they would be involved in deciding some details of the learning environments. They were not certain this would happen but hoped it would. They thought their ideas would be considered but not necessarily incorporated. One teacher wanted the students to be able to help in designing and arranging the internal layout of their classroom after the construction was complete, as the layout would depend on the students' needs and aims. Another teacher said that she had been to a meeting with the principal about how to involve enviro-kids (a group of students that care about the environment) in the rebuilding. They had discussed the involvement of young leaders in the project.

Overall, the teachers had no idea about how to involve students in the design process or whether the students would even be involved. However, if students were involved they felt there must be a visible outcome of student involvement, 
and this might be hard to achieve. One teacher had discussed some issues of the new designs with the students, but this had not changed anything.

The teachers did suggest ways they would like their students to be involved. One teacher said she wanted the children to be able to design a special type of playground, paint the spaces, and choose the furniture. Another teacher said that the display project, suggested by the principal, would be a good way to involve the students. However, they did not know how much the students would be involved or whether their ideas would be reflected in the final designs.

The teachers were also rather worried about the group teaching strategy and its effects on students. They said that the student involvement could be based around what they would expect group teaching to be like, and what they would expect the teachers to do. One teacher said that when she told her students the school was to be rebuilt they "freaked out", as they did not like change.

\subsubsection{THE PRINCIPAL'S COLLABORATIVE} PROJECT (THE DISPLAY PROJECT)

To involve teachers and students more in the design process, the principal conducted a small project where he could collect ideas and thoughts, mainly from teachers and students. The project was inspired by the American teacher's work mentioned in the first meeting with the principal (see section 7.3.4.1). 
The information on the display project was collected from the teachers' focus group (the same focus group discussed in section 7.3.4.5), online and in face-to-face meetings with the principal, and researcher observations.

The principal prepared a site in the reception area and set up some partitions to display ideas and photographs of new and existing and learning areas. The first space discussed on these display partitions was the school library. On the display there were photographs of the existing library, some for new ideas for designing a library, some information about the existing library, an explanation of what the display was about, and an area for participants to put their comments and ideas. The principal was in charge of this small project. He set up the display, categorized responses and collated the results. Students and teachers were not involved in setting up and preparing the display. The target participants were school teachers, school students, and parents. They were expected to provide feedback about the library anytime during the school day, with the display running for a few weeks. Teachers were expected to provide their own feedback and get feedback from the students. They also had nothing to do with the organizing and analysing comments from students or other participants.

As the principal observed, some students came to the display at the beginning of the school day, discussed their ideas together and then left their comments on the display board. 
Other students visited the site at various times during the school day. A few parents and school staff also left comments (Figure 7-11).
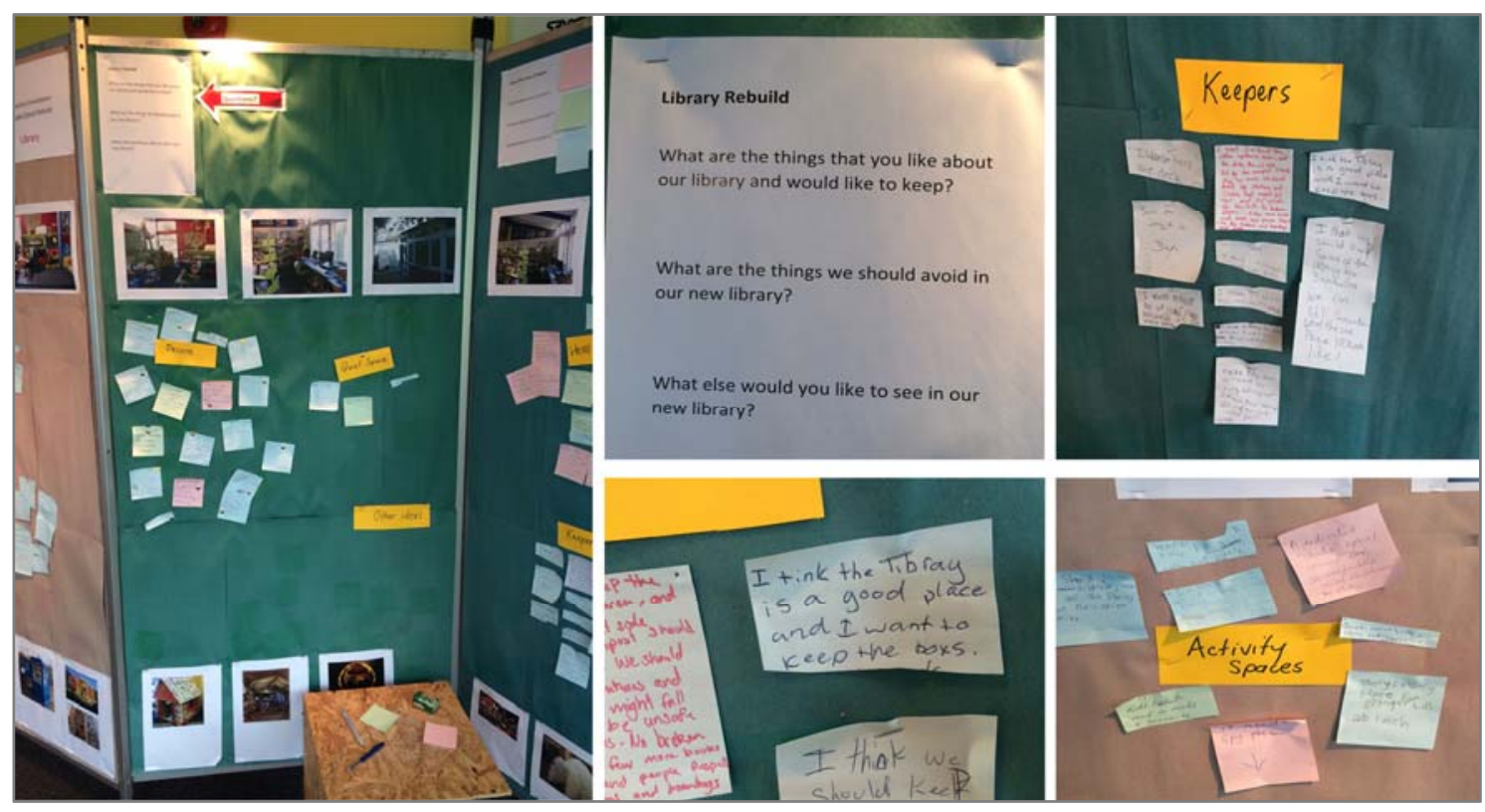

FIGURE 7-11: THE LIBRARY AREA DISPLAY WITH THE GUIDELINES AND PARTICIPANT COMMENTS

The BoT members were concerned the display project might be creating expectations for students which could then not be fulfilled. The principal, however, felt that not consulting students because of this was not a good option.

In terms of analysing the comments, the principal's plan was to group the comments into categories, which were then displayed for people's responses. The principal completed the analysis without involving any teachers or students. The principal was planning to present the ideas from the display 
project and the participants' comments in future communications with the architects and the MoE.

From the focus group with the teachers, it emerged that teachers did not think they would be involved in the display project. At first they were not comfortable about displaying their ideas to the parents and community, as they did not want these to have public exposure. They felt that Google doc was sufficient for them. However, after the discussion, they felt they would like to be involved in the display project. To begin with, they also thought it might be better not to involve students, rather than involving them and then ignoring their ideas. However, one teacher said that this was not a reason not to talk with students about the rebuilding. Another teacher said that if they asked the principal if they could consult the students by themselves, he would let them do it, but was assuming that some teachers might be too busy to do this. However, after the discussion the teachers were more positive about student participation and they felt they would like their students, or some of their students, to be involved in the project. It seems that talking in a group removed some of the fears and barriers to participatory design.

After finishing with the library display, the principal conducted two more displays. The second was for the music room, following the same procedure as for the library display (Figure 7-12). The principal felt the comments on the music room display were thoughtful. The music teacher had been 
involved and facilitated the comments process through discussions about the room with the students. The staff involvement in this display was not as much as in the previous one, as it was about a specialised area and it seems they felt their knowledge did not cover the music room needs. The principal created a file on Google drive to discuss the comments on the music room display. These were divided into groups such as technology, furniture, location, and storage. He put all students' comments under the categories he created to allow staff to comment on these, but there were no comments from the staff on the students' comments and ideas. The principal did not create a Google document for the other displays, but why this was the case was not clear. After the music room display, the principal conducted a display about the outdoor areas of the school. Again, the same settings were considered (Figure 7-13). The outdoor display was the last display covered in this research, although the plan was for a further display on classrooms once the outdoor display process was completed.

The plan was that ideas from the displays would be discussed with the architects as part of the design process, but there was no guarantee that the ideas would be considered in the final designs. 

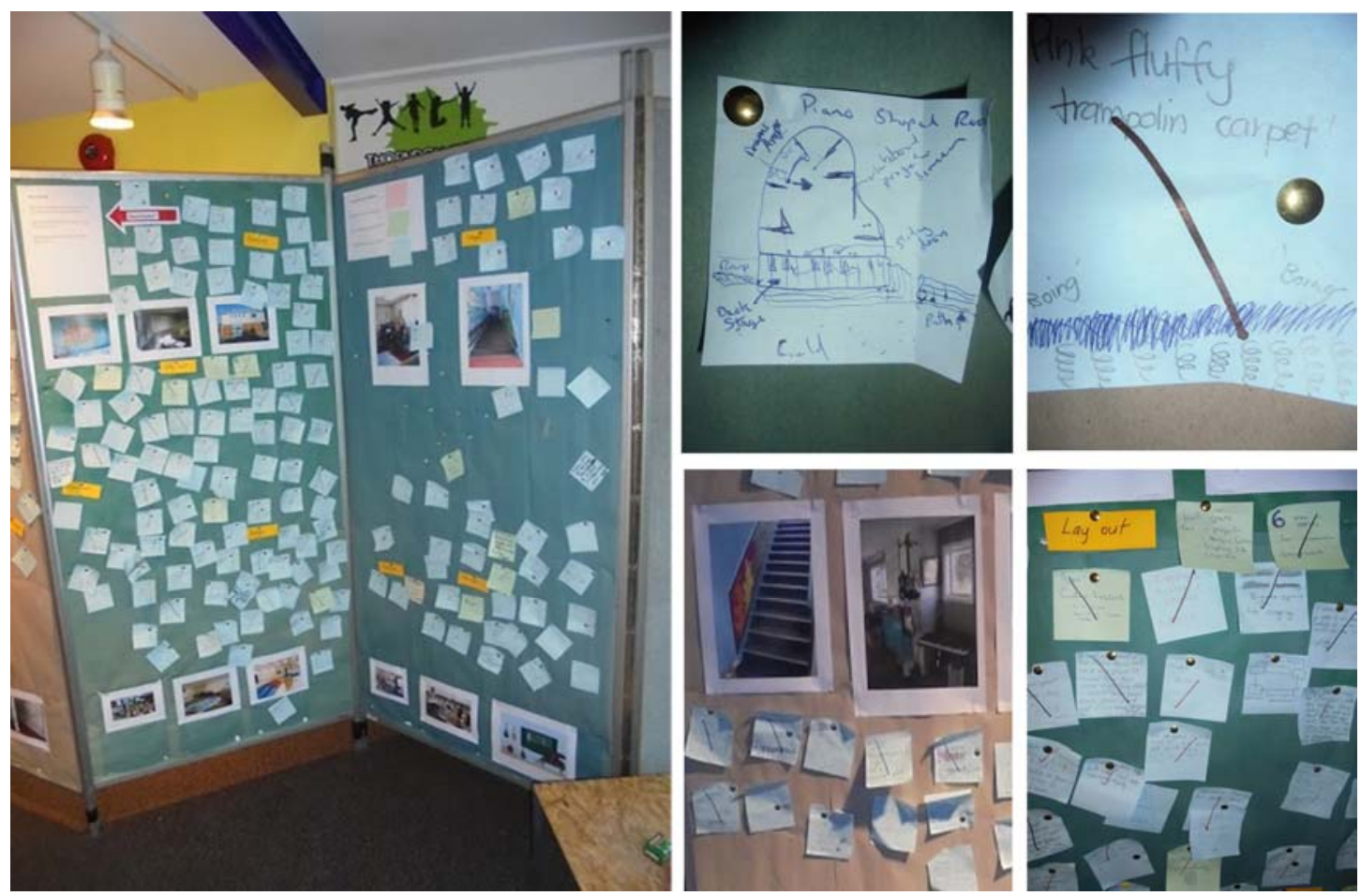

FIGURE 7-12: THE MUSIC ROOM DISPLAY AND PARTICIPANT COMMENTS: PHOTOGRAPHS TAKEN BY THORNDON SCHOOL PRINCIPAL 

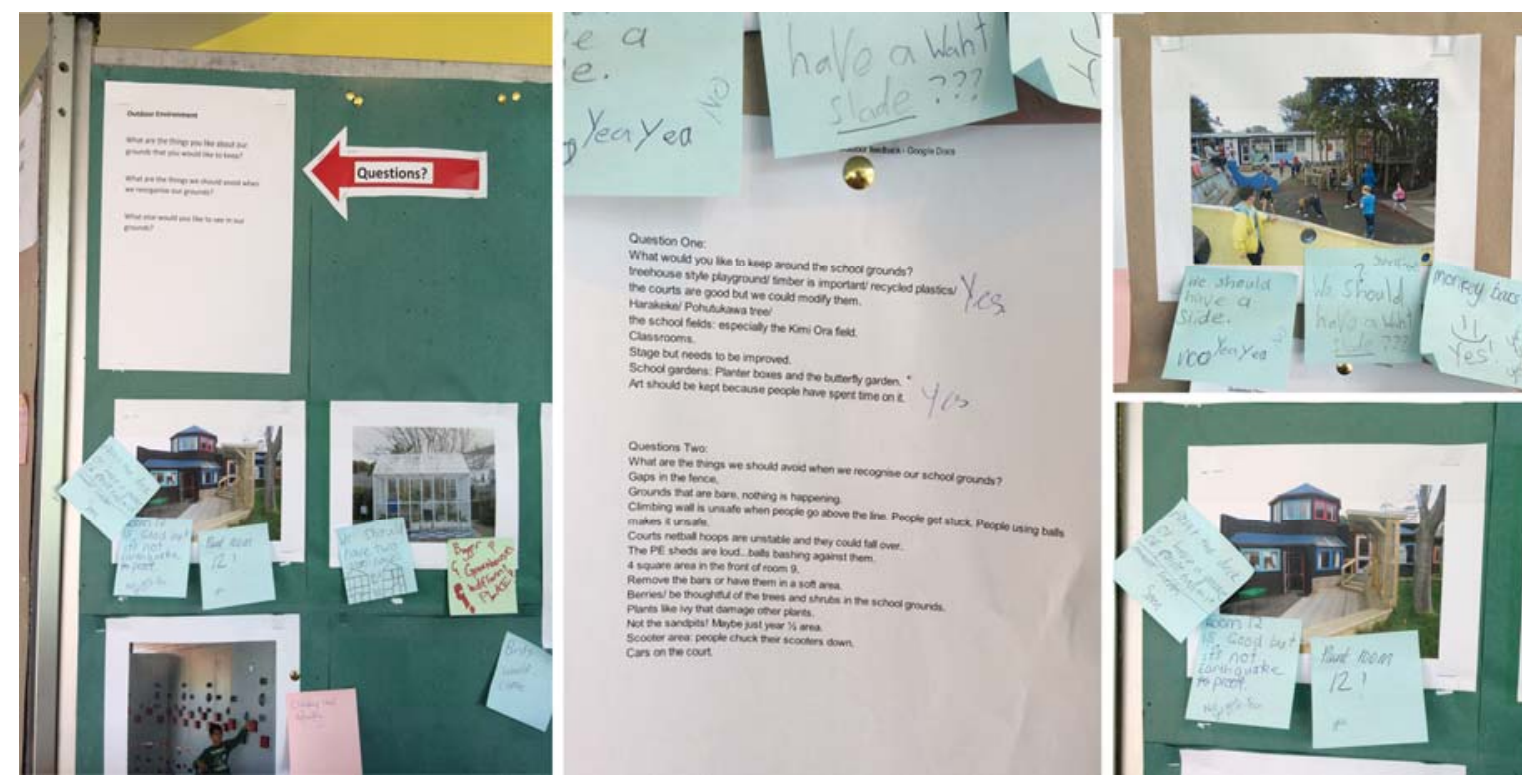

FIGURE 7-13: THE OUTDOOR AREAS DISPLAY, QUESTIONS FOR THE PARTICIPANTS, AND PARTICIPANT COMMENTS

\subsubsection{INFORMATION FROM THE ARCHITECT}

To collect more information about this case study, a meeting with the architects was needed, and the school principal recommended contacting the head architect for this. Because of time limitations, this was done by email. A set of questions was sent to the head architect, mainly about the rebuilding project in Thorndon School and his opinion of the involvement of users in the design process (see appendix $G$ ).

The architect reiterated that formally the client is the Ministry of Education, but that the Ministry requires the architect to consult with the school. However while the MoE were certainly the decision makers, the architect took the inclusive view that the client is the Ministry, the board of trustees, the principal and staff, the students, and the broader school community. 
In terms of the number of meetings between architects and teachers, the architect said they had met once to present the initial thinking to the whole staff and a second time on the school visit to Amesbury School, and that representative staff members were at the presentation of the master plan. Senior staff also visited schools in Auckland with the architects, so there had been extensive opportunities to discuss various ideas together. The architects thought that the current level of involvement of teachers was sufficient, as he knew that the principal was also reporting back to the staff. However, he argued that it was important that all participants in the project understood that the school was not being designed for that particular group of staff but staff in years to come, irrespective of how compelling or strongly held some views might be.

In terms of student involvement in the design process, the architect said that he and the principal had discussed this. He knew that the principal was involving the students but did not say how this was happening, which raises the question as to whether he knew about the students making comments on the display boards. He also claimed that teacher and student involvement would be important when getting into the interior design. He said that involvement means different things to different people, and at the time of this interview, the architects and the school were merely establishing the scope of the project, something that was still far from settled. The architects had not yet really started designing any 
buildings, nor did they know how many they were supposed to be designing.

The architect's opinion on hearing that the teachers thought their voice was not necessarily considered in the design process was that the design process had not really started. However, he claimed that the architects had heard from teachers while the master plan thinking was being developed and the teachers' voice was considered in this. According to the architect, decisions about site layouts clearly reflected the teachers' voice, although the teachers were just one of many voices that the project needed to consider. The architect said there were plans for having more user involvement in later stages of the design process

\subsubsection{DISCUSSION OF THE THORNDON SCHOOL REBUILDING PROJECT CASE STUDY}

In the first meeting with the principal, the researcher observed that the principal had a good background in the design of learning environments. This background knowledge could produce a clear understanding of what is needed for the new project. The principal was supportive of user (teachers and students) involvement and inputs into the design projects. The only barrier to this involvement was the results of a previous experience that ended by disappointing the students. The principal was willing to conduct an exercise or small project that would involve users in the design process. 
The master plan was completed with consultation with a group of parties including the school staff. This information is mentioned in the master plan file and indicates that the architects were thinking of involving teachers from the early stages. However, there is no information about how the teachers were involved, or if that involvement was sufficient for them. However, the master plan file mentioned nothing about the involvement of students, which may indicate that the architects thought that involving students at that stage was not necessary.

In regard to the Google drive created by the principal to involve teachers in the design process of the rebuilding project, the use of social media seems to be more effective when it is focused on a certain project more than for thinking about the design of learning environments in general. It still misses much potential discussion and communication between staff and the principal, and between staff themselves. However, it could be improved and this might happen with the advanced and more detailed stages of the project. It is also missing the students' voice, which is a very important issue if the project intends to involve students in the design process.

From the first meeting with the teachers, the researcher observed that teachers needed encouragement to talk and not all teachers participated in the meeting. This could also happen in any meeting or focus group between teachers and architects. This might have happened because the meeting 
included all school teachers and the principal, and some teachers did not feel comfortable talking in front of everybody else. The researcher also observed that teachers had no strong voice in terms of changing or adding to the project. This could affect the teacher involvement negatively. If the teachers' voice does not influence the final design, the purpose of user involvement has been missed.

Teachers have many ideas for their learning environments but they do not post these on the Google doc and nor do they keep records of these in any type of format. This might be indicative of a lack of confidence in sharing their ideas in the Google doc or it could be because they think about new ideas while they are discussing the project and then forget to document these later. The principal was also not interested in recording these thoughts.

The teachers liked to discuss how the new project might affect their teaching styles. They wanted the new buildings to reflect how they work every day. The question is how much does their work affect the design process and final designs? Did the principal, project manager, and architect listen carefully to what teachers have said about the use of learning environments? All these questions could possibly be answered from analysing the final designs, but unfortunately, this case study did not cover all the project stages and the final design because of the time limits of this thesis (see section 8.1.5) 
In the focus group with a number of teachers, several issues were noticed. In the first meeting the principal said that for the rebuilding project they had the benefit of having existing teachers and teaching styles from which to create the base of their designs, and this is better than new school projects where they have to create new teaching styles without knowing the teachers. However, in the teachers' focus group, the teachers said that they were informed about most of the designs instead of discussing them, and that the new designs supported a different teaching style from that currently in use. This was also a new teaching style for most of the teachers. It seems, therefore, that this project is little different from other new school projects. The principal claimed that teachers were involved in the design process and that he wanted to encourage more of their involvement. However, from the focus group with teachers, it appeared the principal was making most if not all decisions by himself, assuming that the teachers were too busy to take part in these decisions, while the teachers were interested in being more involved and were ready for all types of involvement. Perhaps the teachers need to be more aware that involvement in the design process is possible and that architects also want this involvement. The teachers felt that they were not sufficiently experienced in architecture to have a 'loud voice' in the design process, but when they discussed the details of designs in the teacher/architect workshop (phase three of the research section 7.2) they discovered that they could work with 
architects without having any special experience. They were encouraged more when they knew that the main results of the 2013 architects' survey (see section 6.3.4) were that architects want more teacher involvement and want to communicate with teachers and students directly. The teachers were also afraid of involving students and then letting them down when the student ideas were not considered in the designs. They leaned toward rejecting any method that might not literally use student ideas and therefore would reject the collaborative approach, as they believed it could not work. This might be because they have not tried working with children and dealing with them as proper clients for the rebuilding project. They do not know how students will react toward any new method of involving users, even though there are overseas studies that provide teachers with good examples of student involvement in the design process. It was noticeable that teachers were more engaged in this discussion than in the first meeting where all teachers and the principal were present. This suggests that having small group meetings and focus groups can generate more discussions and ideas.

In terms of the display project, having the display with a selection of ideas chosen by the principal may affect students' thinking. It is hard to expect students to generate ideas out of what they were given in the display. Instead, students should have the opportunity to look for new ideas themselves, either from the Internet or books. Students would need a space to display these ideas so that other students can then comment 
on them, which would reveal what students expect in such a space. Not involving the teachers in analysing the comments on the display project, especially those from their students, indicates how the teacher involvement in the whole design process is limited. Teachers are supposed to know their students better than anyone else.

Teachers were initially hesitant about participating in the display project, as they were afraid of public comments on their ideas. However, when they discussed the project in the focus group they started to become engaged and wanted to be involved in the display project from the preparation stages. Despite this desire, the principal remained in charge of everything, from setting up the display to analysing the comments. This may indicate weak communication between the principal and teachers in terms of the design process. The principal seems to think that teachers are too busy to be involved in such a display project, yet the teachers wanted to be involved from the preparation stages. The principal selected the library as the first zone for which to have student and community input. This may reflect the type of projects shown in the prize-winning school designs, where the learning environments (classrooms) are almost ignored (see section 4.1).

The architect interviewed by e-mail did consider teachers and students to be part of the client body. He believed in the importance of consulting and involving teachers in the design 
process with the caveat that these teachers might be exchanged for others over the years. However, communication with the children was currently only happening through the principal. This might show that the architects have assumed that direct communication with students was not important at that stage.

The architect also argued that up to the time of the interview, the real design of the rebuilding project had not yet started. This conflicts with the information from the master plan and the principal and staff interviews. According to the school, especially the staff, the design of the rebuilding had started by the time of this investigation. This suggests conflicting views of what constitutes design, the staff feeling that the overall plan is important to them, whereas the architect thinking their involvement should be left to more detailed stages in the process. However, if the teachers had been more involved in the whole process they would probably have a better understanding of the stages of the design process. One of the things about participatory engagement is having people engaged from the beginning, as evidenced in the Sorrell Foundation project and the "Inside Out" project (see section 3.4). The architects also said that the teachers' voice was important before starting on the details. This might mean that the way the teachers had been involved at that moment was acceptable in the architect's opinion, whereas the teachers were not so happy with that level of involvement. This again 
might indicate the weak level of communication between the project parties.

The architect did not mention the Google doc, although he was a member of it. He also did not comment on the display project suggested and conducted by the principal, possibly because he did not know about it, which gives another indication of the weak and indirect communications between the architects and the school.

\subsubsection{PHASE FOUR CONCLUSIONS}

The whole process of what is supposed to be participatory design in the rebuilding of Thorndon School is confusing. Every party to the project had a different view of what was happening, and sometimes these views were opposite and not related to each other. All parties support user involvement in the design process but there is a clear lack of agreement over how this might be achieved. Having multiple clients for a project can lead to this breakdown in communication. The teachers also thought their level of involvement was insufficient to affect the final designs. The principal and the architect also thought that the teachers' ideas should not affect the designs as the teachers could change over the years, even though teachers are still the best people to know about how children learn. The principal said he wanted students to be involved in the design process (see section 7.3.4.1) but their only involvement to date has been the ability to post comments on the display. It seems this might not have 
happened without the intervention of the researcher. Discovering the students' voice through an exercise such as the display project has potential, but the student input may still be influenced by the person doing the analysis, in this case the principal, who already has a key role in the whole design process. This may indicate that direct communication between students and the architecture team is still needed for true participatory design.

\subsection{Phase Five: INVOLVING USERS IN A}

\section{CLASSROOM LAYOUT DESIGN PROCESS}

This phase is a multiple case study that involved two classrooms from two different schools in Wellington city. The main reason for choosing these classrooms was because there was already communication between the researcher and the principals of the two schools, and because they agreed to participate in these case studies. The case study involved rearranging the furniture of each classroom based on work on revising the layout by the classroom teacher and students. The following four sections explain these case studies in detail.

\subsubsection{The aim of the Case Studies}

The previous phases of this part of the research did not show enough student involvement in any design process. The surveys did not involve students directly, so nothing further about what students think can be gained from these. The social media tried to involve students but there were not enough responses to create a reliable conclusion about 
student involvement. The workshop discussed student involvement with teachers and an architect, but as there was no experience of this to discuss, nothing further could be learned. Some participants did not even support the direct involvement of students. In the case study of the rebuilding project, the only student involvement was through the display project, but students had to respond to what was on the board and there was no forum for them to give their own ideas. As a result of these previous phases, there was a need to develop a study that would cover this missing area regarding student involvement. Thus, the aim of the following two case studies was to observe the involvement of students and teachers in a simple design process around the layout of their existing classroom. This included helping students and their teacher to evolve a classroom furniture layout design without any budget implications.

\subsubsection{Method SELECTION}

The methodology used for the next case studies is a multiple case study methodology, which was used because it involves using different methods of observing and analysing a design process. Other methods such as a survey or focus group might not give sufficient information, as they only cover the design process from one side. Yin (1994) suggests a set of information and data need to be collected through different methods. As described for phase four, this case study also needed a question, proposition, units of analysis, methods of data collection, and data analysis. 
As this phase used a multiple case study methodology, and the pilot study did not give rise to any changes in the design of the case study, the pilot study was one of the two case studies in this phase.

To start the case study, a question needed to be defined. As the point of this case study was observing the student involvement and discovering whether this involvement affected the final designs, the case study question became: Would involving students in a design process change their perspectives of their learning environments? This question includes finding out if students would like to be involved in the design process and how they would like to communicate their ideas.

Based on previous information about participatory design (see section 3.3), and how it might deliver more efficient learning environments, this study proposed that trying to involve students in a design process will affect their perspectives toward their learning environments positively. This case study could make them think more about what could be changed and created according to their needs, instead of being in a space designed by other people that might not correspond to their needs.

In terms of the units of analysis of this multiple case study, the study involved two classrooms in two different primary schools in Wellington city, Thorndon School and Te Aro School, assigned the names Te Aro Classroom and Thorndon Classroom. In Te Aro Classroom there was one teacher and 29 
students aged 9-11 years. In Thorndon Classroom there was one teacher and 23 students aged 7-9 years. The researcher worked on these case studies as an architect, helping and enabling the teachers and students to take part in the design process. So the units of this phase were one architect, two classrooms, two teachers, and 52 students.

As discussed in phase four, in the case study methodology there are six possible sources of evidence: documentation, archival records, interviews, direct observation, participant observation, and physical evidence (Yin, 1994). As the aim of this case study was to observe a design process where teachers and students are responsible for almost the whole design, the methods used for collecting data were interviews, observations, and physical evidence.

The researcher as an architect had to work with the teachers to introduce the project to students and figure out the best way to gather and analyse ideas, identify the common problems, determine how to generate good ideas, and then present these to the students and teachers. The researcher's role then changed to one of observing students and teachers while they were working on the project.

\subsubsection{INTERVIEWS}

The study involved interviews with the teachers of the classrooms. The aim of these was to discuss any previous work regarding the classroom layout, discuss the students' 
work, and decide about the different stages of the case studies. The interviews were completed either face to face or online via email. In the addition to the interviews with the teachers, some discussion sessions were held with the students. The aim of these was to discuss the students' opinions about the different stages of the design process.

\subsubsection{OBSERVATIONS}

The researcher was observing the progress of the design process behind the furniture rearrangement. The observations included observing students while working on designing new layouts for their classroom, observing and analysing students' comments during the process, and observing students' reactions toward the new layout at the feedback stage.

\subsubsection{PhysicAl EVIDENCE}

The physical evidence included photographs and floor plans taken and drawn by the researcher covering both the old and new classroom furniture layout. A part of the physical evidence was taking the measurements of the classrooms and the existing classroom furniture to provide a set of realistic scale components for the students and teachers to use in the redesign.

As for phase four, the data were analysed according to the proposition mentioned earlier. All the findings were analysed based on the proposition that trying to involve students in a design process will positively affect their perspectives toward their learning environments. The findings are discussed in the 
following sections, according to the different stages of this part of the project.

The design process in the case studies started with an exploration stage in which the researcher collected information about the classroom layout and the classroom dimensions. This stage was completed with information from an interview with each teacher and the physical evidence. The second stage was a brainstorming session that involved discussing general information about architecture and classroom layouts. This stage was completed via observations and discussions with the whole classroom, including the teacher. The third stage was the students rearranging the classroom layout on paper and discussing the new designs from the students and the teacher. All students, in addition to the teacher, were involved in this stage. This stage was covered by observations. The fourth stage was deciding on one final design for the classroom layout. The stage was completed by whole class gatherings and discussions. The teacher was also involved. The final stage was getting feedback from the students via a small questionnaire for all students of the studied classrooms. Through the whole process, a social media blog was set up for each classroom where students could post comments and share their ideas and work. 


\subsubsection{FINDINGS AND DISCUSSIONS}

The different stages below discuss the findings from the interviews, observations and physical evidence. The stages are divided as discussed (see section 1.4.2.3) and the order of the stages represents their time order in the design process.

\subsubsection{EXPLORATION STAGE}

The exploration stage included an interview with the teachers and collecting the dimensions of the classrooms. The interview with each classroom teacher was a one-to-one semistructured interview with open-ended questions, with the hope of creating an open discussion in order to collect information about the furniture layout of the classroom. It included questions such as "What have you done in terms of changing the furniture layout to suit you and your students?" and "How do you and your students use the classroom?" (See appendix $\mathrm{H}$ ). This stage also included taking measurements of the room, furniture, and fixtures. The researcher asked each teacher, at the end of the interview, whether they preferred to involve students in taking the measurements or whether this should be left to the researcher. The findings and answers to these questions are discussed separately below.

In Te Aro Classroom, the teacher discussed an exercise she had completed with her students during the first week of Term 1 in order to change the classroom layout. She put students in groups and gave them a sheet about the aim of the exercise. The sheet included questions and statements for students to discuss such as "What spaces do you think the 
classroom should have? Why?", "What should be on the wall?", "Using desks as tables not desks", and "Lighting (darker and lighter spaces in the classroom)". Figure 7-14 shows the sheet with all questions and statements. In addition to this sheet, the teacher showed students some examples and photographs of furniture layouts in other schools. She also provided a template of the classroom borders so students could draw different furniture layouts within these (Figure 715). After the drawing sessions teacher and students discussed the main problem, which was, as the teacher said, the mat area being too small. As a result, they changed the mat area to another side of the classroom, but they still have the same problem of it being too small for all the students to use at once. According to the teacher, students had brilliant ideas when they were working on the location of the furniture during their drawing session, but because they could not manage the scale of the furniture correctly, she could not benefit from their drawings. Students, the teacher said, were very excited to work on this exercise. However, they felt disappointed when they found that their ideas did not fit in the classroom.

Apart from this exercise, the teacher said that there were no major changes in the furniture layout. She only moved a table once during Term 1, after the exercise. They do not change anything on a daily basis. 
The teacher liked the idea of having a few desks to work on, rather than a desk for each student, but also felt students like to have their own desks and their own spaces. Other issues with the furniture layout are about the fixed settings in the classroom. The main settings used in the classroom are the mat area and desks. Although the teacher encouraged students to work anywhere, students prefer to work on their desks, especially when writing.

The teacher preferred not to involve students in the measurement phase, as it would waste their school time. Thus the researcher took the measurements alone after school to avoid taking any school time. Figures 7-16 and 7-17 show photographs and the floor plan of the existing classroom. The existing classroom layout from Figures 7-16 and 7-17 does not reflect student's work in teacher's exercise in Figure 7-15. 
WALT: create a variety of spaces in our classroom to benefit our learning WALT: research and analyse different learning spaces and their purposes

With your partner. Think and talk about the following questions. Write down your thoughts in exercise book:

1. What spaces you think the classroom should have? Why?

2. Where the spaces would fit best and why?

3. Mobility/ access- will it be easy to move around and access particular areas?

4. The furniture that would best be used for the space

5. Using desks as tables not desks

6. Lighting (darker and lighter spaces in the classroom)

7. Windows- how will this affect the learning in that space?

8. The photos you have viewed from other classes

9. Items we could bring in from home or items we could make ourselves

10. On the wall? What should be on the wall, why?

11. The research-different spaces and their purpose

WIN

- A variety of spaces to learn in

- Use as much of the furniture as you can (remember to draw them on the piece of paper)

- Label and colour each space in your classroom with different colours

- Write a list about the benefits and uses of each spaces

FIGURE 7-14: THE EXERCISE SHEET CREATED BY THE TEACHER, TE Aro Classroom. 


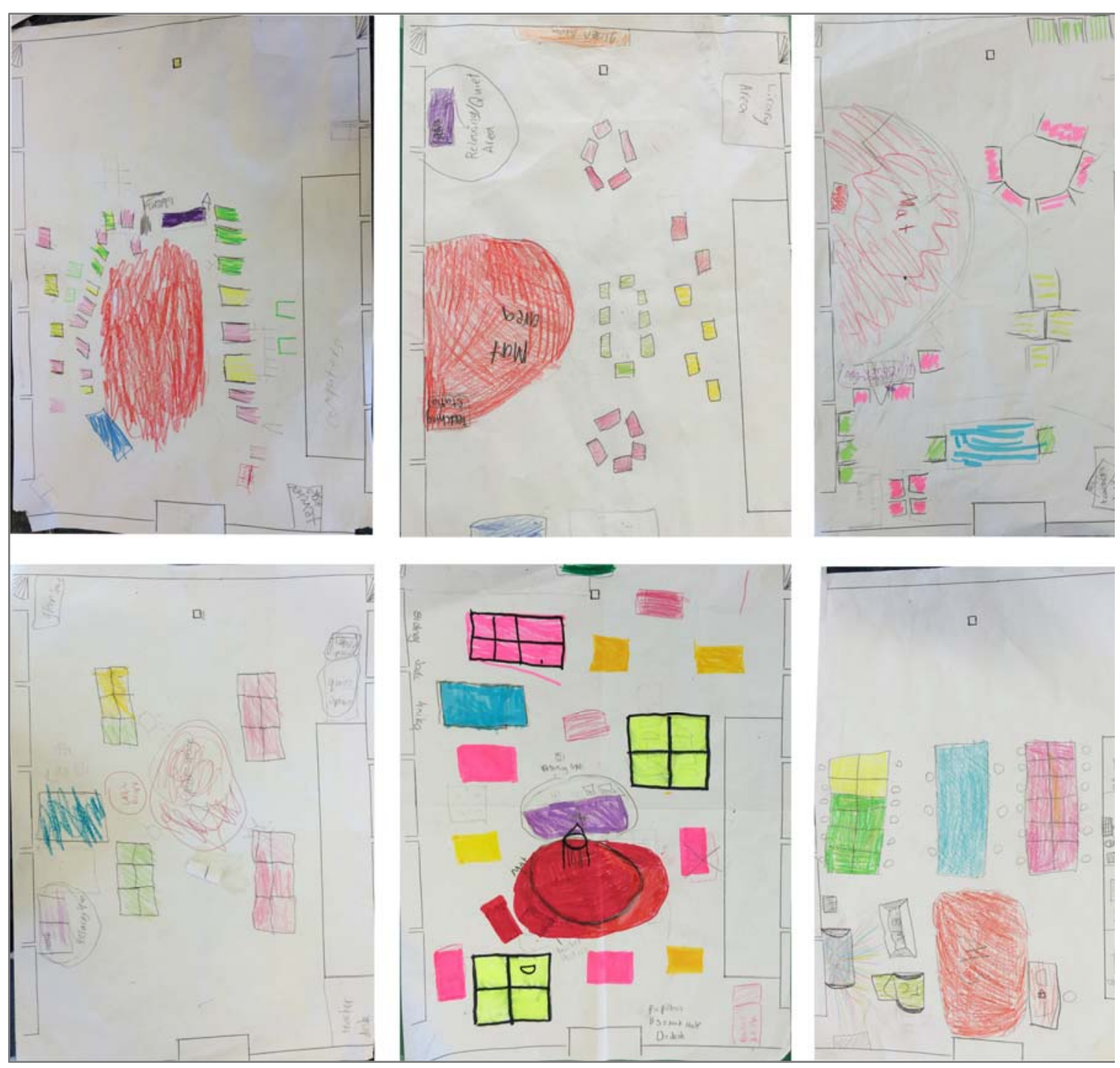

FIGURE 7-15: STUDENTS' WORK IN THE EXERCISE CREATED BY THE TeAcher, Te Aro Classroom 


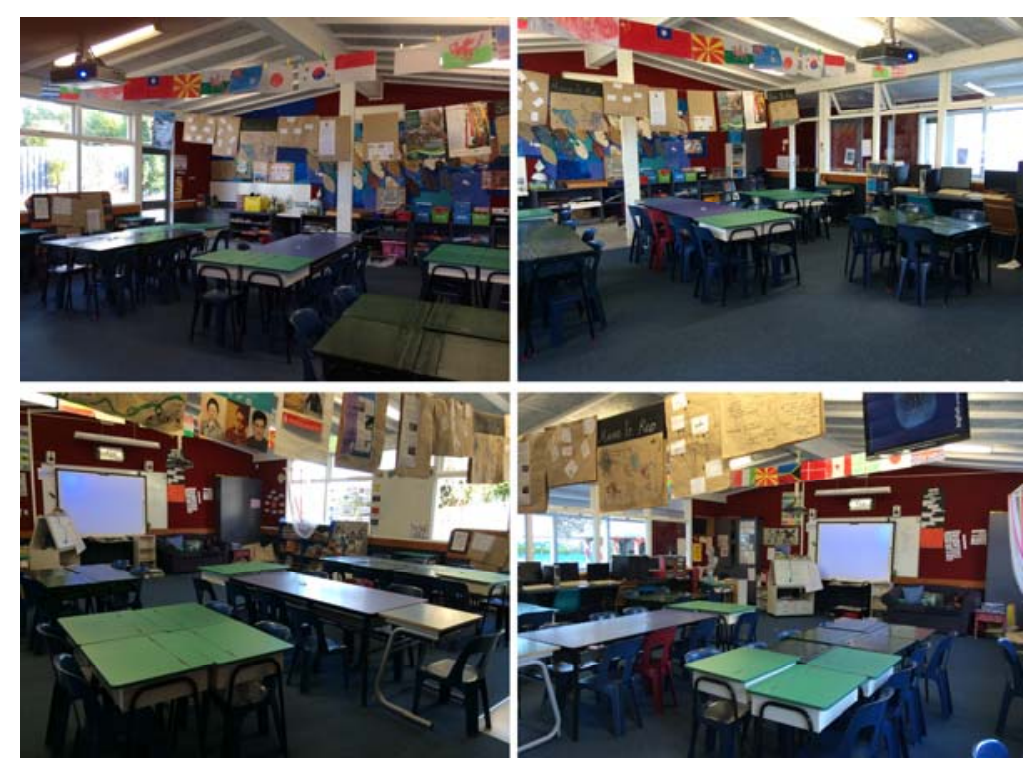

Figure 7-16: Photographs of the existing layout, Te Aro ClassRoom

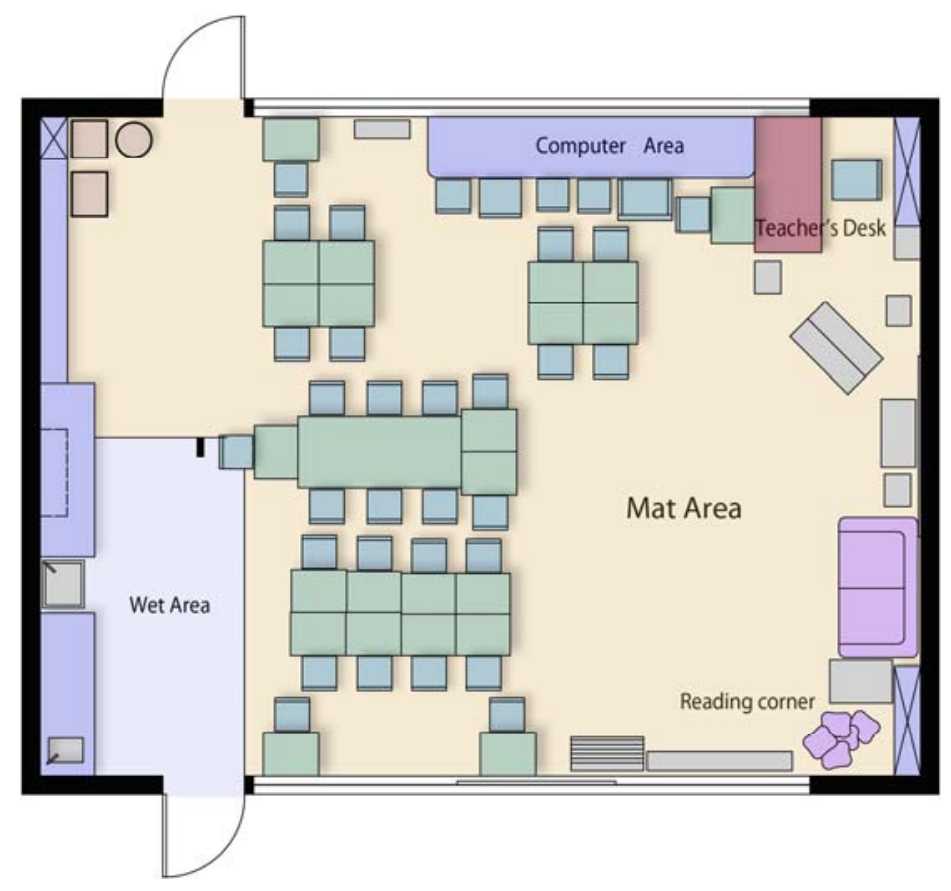

Figure 7-17: The existing layout, Te Aro Classroom 
In the Thorndon Classroom interview, the teacher said that they had not changed anything in the furniture layout, either at the beginning of the previous term or during the current term. He said that the classroom size is very good for 24 students (year 3-4, aged 6-8 years) and that they are happy with this classroom. He also said $50 \%$ percent of the work is completed on the mat and the other $50 \%$ at the tables. Students can work wherever they want, as they do not have personalized desks. The teacher said that if they had the money they would have bought new furniture for the classroom but that otherwise it was a good classroom. The teacher said that they were happy to change the layout and try new arrangements.

After interviewing the teacher, photographs and measurements were taken with the help of students, as this was the teacher's preference. He said that they could learn from this measurement phase. First, students were gathered in the mat area and were asked a number of questions in order to prepare them for the first stage. These included questions such as "Do you know what architects do?", "Do you know what a floor plan means?" and other questions about the shape of the classroom and measuring furniture. Students engaged very well with this discussion. They answered most of the questions correctly. They knew that a floor plan is only a two-dimensional drawing and that the floor plan, as they said, is like looking from a high place down onto the classroom. 
Next, students were divided into four groups and the classroom was also divided into four zones. Each group helped the researcher to figure out the shape of the zone (if applicable), figure out the shapes of the furniture, and take the necessary measurements of this. Students were very excited about using the measuring tape and converting the dimensions from millimetres to centimetres. They enjoyed guessing the dimensions of the furniture and which pieces were bigger or smaller than others. Figures 7-18 and 7-19 show photographs and the floor plan of the existing classroom.

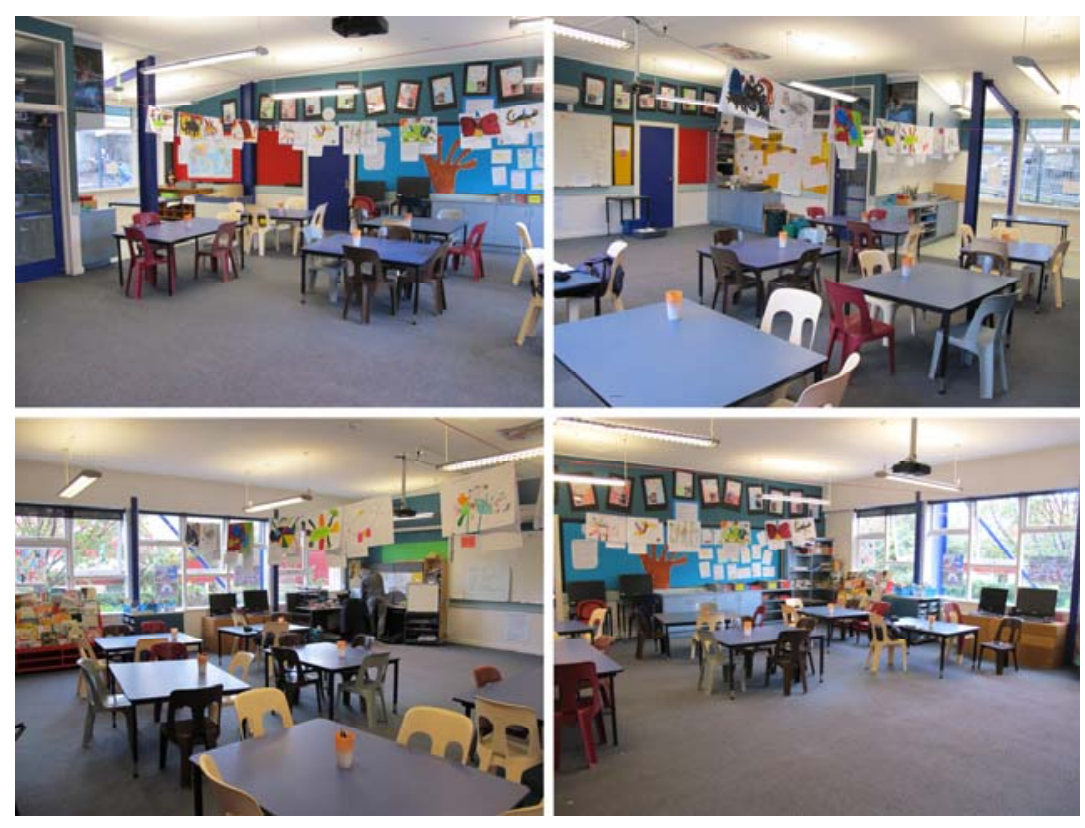

Figure 7-18: PhOtographs Of THE EXISTING LAyOUt, THORNDON ClassRoom 


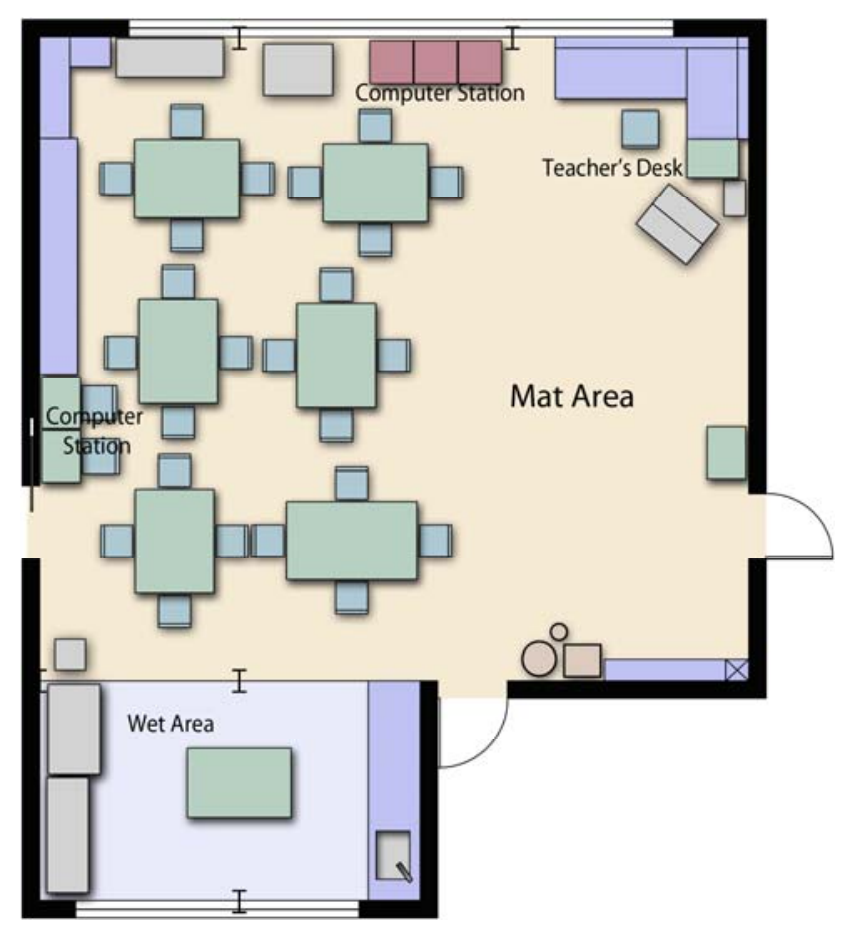

FigURE 7-19: THE EXISTING LAYOUT, THORNDON ClASSROOM

\subsubsection{BRAINSTORMING SESSIONS}

For the second stage, the researcher conducted brainstorming sessions that involved the teacher and all students in each classroom. These were an introduction to the first exercise with the students. The brainstorming sessions were divided into two parts. The first included questions such as "What is a classroom?", "What do you need inside a classroom?" and "Who uses the classroom?" (see appendix I). In the second part, the researcher presented a group of floor plans and photographs of primary school classrooms. One of the floor plans was for a traditional style classroom with three rows of desks facing a whiteboard, while other floor plans included specialized zones such as a reading area and a computer 
station (Figure 7-20). The sessions were completed in the afternoon, inside the studied classroom.

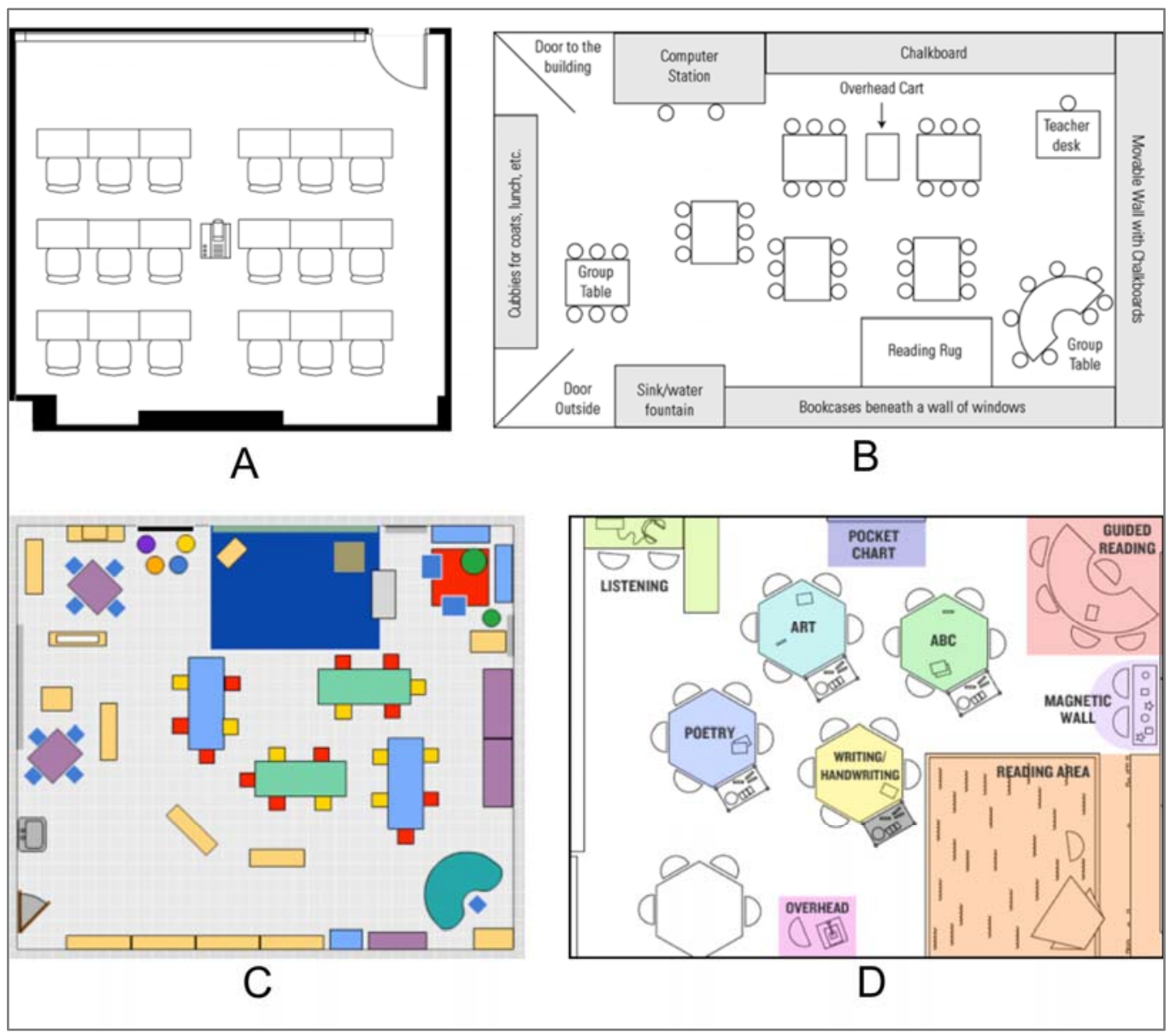

FIGURE 7-20: THE CLASSROOM LAYOUTS USED IN THE

BRAINSTORMING SESSIONS. (A) IS A TRADITIONAL CLASSROOM. (B, C, \& D) ARE CLASSROOM LAYOUTS WITH SPECIALISED ZONES ${ }^{2}$

${ }^{2}$ References for the photographs are: (A) from:

http://www.rooms4biz.com/Downtown-Toronto-Classroom-6, (B) from: http://www.ascd.org/publications/books/104135/chapters/ClassroomManagement-and-Organization.aspx, (C) from: 
In the Te Aro Classroom the first meeting also started with questions about architecture and architects. Students seemed to be familiar with these terms. They said that architects design and plan buildings and decide what is suitable inside the building and what is not.

In the brainstorming session, students explained that a classroom is a space for learning in, somewhere to put their stationery, and somewhere to use learning resources. They agreed that students and their teacher are the main users of a classroom. When they were asked about what they need in the classroom, the first things they said were students and a teacher. Then, they added elements such as computers, and stationery. One student said that the most important thing in the classroom is having a proper lighting, as students cannot work in dark. In terms of their opinions about classroom furniture, the students were divided into two groups. One group said that they need furniture to learn while the other group said that they thought furniture was unnecessary and they could learn without it. Students then argued about having furniture in the classroom. In the end they agreed that

\section{http://www.personal.psu.edu/jmb5025/blogs/jess barnetts portfoli/2008/12/class} room-learning-environment-plan-classroom-layout.html, and (D) from: 
a classroom should have a furniture-free space for students who like to learn without furniture, in addition to furnished areas for other students. During the brainstorming session, students were also asked to close their eyes, imagine any classroom, and say the first thing they see in it. Students said a number of random things including a beanbag, the floor, and a whiteboard. In terms of the main areas of any classroom, students mentioned desks and tables, library area, art area, "bored area" (for bored students), and computer area.

For the second part of the brainstorming session, using the floor plans and pictures of primary school classrooms, students started with questions about the details of the floor plan, such as the door symbol. In general, the majority of students did not like the traditional style classroom. They thought that is was too boring, as there were only desks and chairs. Students said that they need to move around and these classrooms do not allow them to do this. They liked classrooms with specialized zones, as they are more complicated than the traditional ones. They liked the movable walls in some floor plans but said that they should lead to a space for the same classroom, such as a small library, instead of opening to another classroom. One of the floor plans was of their current classroom. They did not know this at the beginning. Their first impression was that they did not like it. After few moments some students realized that it was their 
classroom. Students were shocked because it did not look as good as the floor plan. They said it looked better in reality.

In the Thorndon Classroom the brainstorming session was the first activity. Students defined a classroom as a place for working, learning, writing, and becoming better educated. They said that the classroom is different from other places because in a classroom there is a teacher and children, and they can learn from each other. They agreed that the main users of any classroom are the students and teachers. In terms of the things needed inside a classroom, students mentioned desks and chairs, stationery (paper, pens and pencils), and learning resources (books and computers). Some students said that they do not need furniture inside a classroom for learning, as they can work or read on the floor. Other students said that they need furniture, as they need hard surfaces for writing. Some students wanted furniture so that they would not have to eat their lunches on the floor, where it can be very dirty and uncomfortable. When the researcher asked students to close their eyes and imagine a classroom and say the first thing they see, students mentioned a door, desks, children, and floor. Students said that each classroom needs a mat area, bookshelves, an art area, computer station, tables, a whiteboard, a teacher station, a dance area, and a reading corner. Students would like to have living creatures, like a class pet, inside the classroom.

In the second part of the brainstorming session, commenting on the floor plans, some students liked the traditional 
classroom layout. Students liked the desks being in rows, and that it seemed its students did not need a lot of different stuff inside the classroom. They said that it is good for learning from the projector in this way, as it would be just like watching a movie. Some students did not like this layout, as it needed more types of furniture, such as a teacher's desk. When students were introduced to the other floor plans with the specialized corners, they liked them. They said that they have many things such as reading area, art area, and teacher station, which is good for a classroom. Some students liked the furniture-free areas in these floor plans. They said they could do different activities in the empty spaces. They liked having different shaped furniture inside the classroom. They also liked the coloured floor plans more than the gray-scale floor plans. Some students said that in these floor plans, there are too many desks and tables. They would like less furniture and more free space. When they saw their classroom, over half of the students liked it before knowing it was their classroom. They did not comment on why they liked it and were excited to discover it represented the real classroom.

After the brainstorming sessions in both classrooms the first task was introduced, which was commenting on their existing classroom layout. The private blogs for each classroom were also introduced and students were shown how to use the blog. 


\subsubsection{REARRANGING THE CLASSROOM LAYOUT} WORKSHOP

The workshop was in two parts. The first was discussing students' comments on the existing classroom layout, which took place over one week. There was no selected number of hours for this task. The teachers encouraged students to complete it during any free time in the given week. The second part was an exercise for creating ideas for new classroom arrangements using the existing furniture. For the second part, students were given four options to complete the exercise: drawings, writing, recording voice comments, or creating videos. For drawings, the researcher provided the floor plan of classroom fixed features and architectural borders and a floor plan with all the existing furniture so students could cut this out and try it on their new layout without having a problem with scale. For writing, the researcher provided 2 sheets that included a small floor plan so students could refer to it while writing their ideas. For voice recording, a voice recorder was provided, along with a video camera so students could create their own video about their classrooms. The researcher also provided some rules for the exercise to help students reach better classroom layouts (Figure 7-21). 


\section{Rules for redesigning the internal furniture layout}

- Unfortunately we cannot afford new furniture, so all we can do is rearrange the old furniture to make the classroom work better for learning.

-You can get rid of any piece of furniture you feel you do not need.

- There is some fixed furniture that can't be moved.

-You can change the function of any piece of furniture.

-Make sure that the classroom works for all the classroom students.

\section{FIGURE 7-21: THE RULES FOR THE REDESIGN EXERCISE}

In the Te Aro Classroom, the comments on the blog about the existing classroom layout were in three categories. The first category contained comments on the desk arrangement. Almost all the comments in this category were about how crowded the desks were. Some students commented on the desk arrangement being boring. "They need [to be] dynamic," as one student said. The second category was about the mat area. Although this was observed to be little bit crowded in use, some students commented that the mat area was too big. Others said they would like the location of the mat area to be changed. The third category was for random comments. A student commented on the window treatments and the fact there are no curtains to block the sunlight when using the data projector. Other students suggested creating a bigger library/reading area. Some students suggested adding more soft settings such as beanbags.

After discussing the comments with the students, the exercise was introduced. Students were excited about participating in 
the exercise. Some students were amazed that they had the chance to express their ideas through using a video camera or voice recorder. However, later, they discovered that drawings were easier than creating videos or voice recordings. As a result, most students chose to draw their ideas for the new classroom layout. Students chose to work in groups of two or three. They completed the exercise using the different existing settings in their classroom. Some students used their desks, others were sitting on the floor, and some were sitting on the sofa (Figure 7-22). Not all students produced work for this exercise. Some of them started discussing ideas with each other but did not have the time to record, write, or draw them. Students had 90 minutes to complete the work but some students had another task to do during this time that made them leave the classroom and their work for a while. 


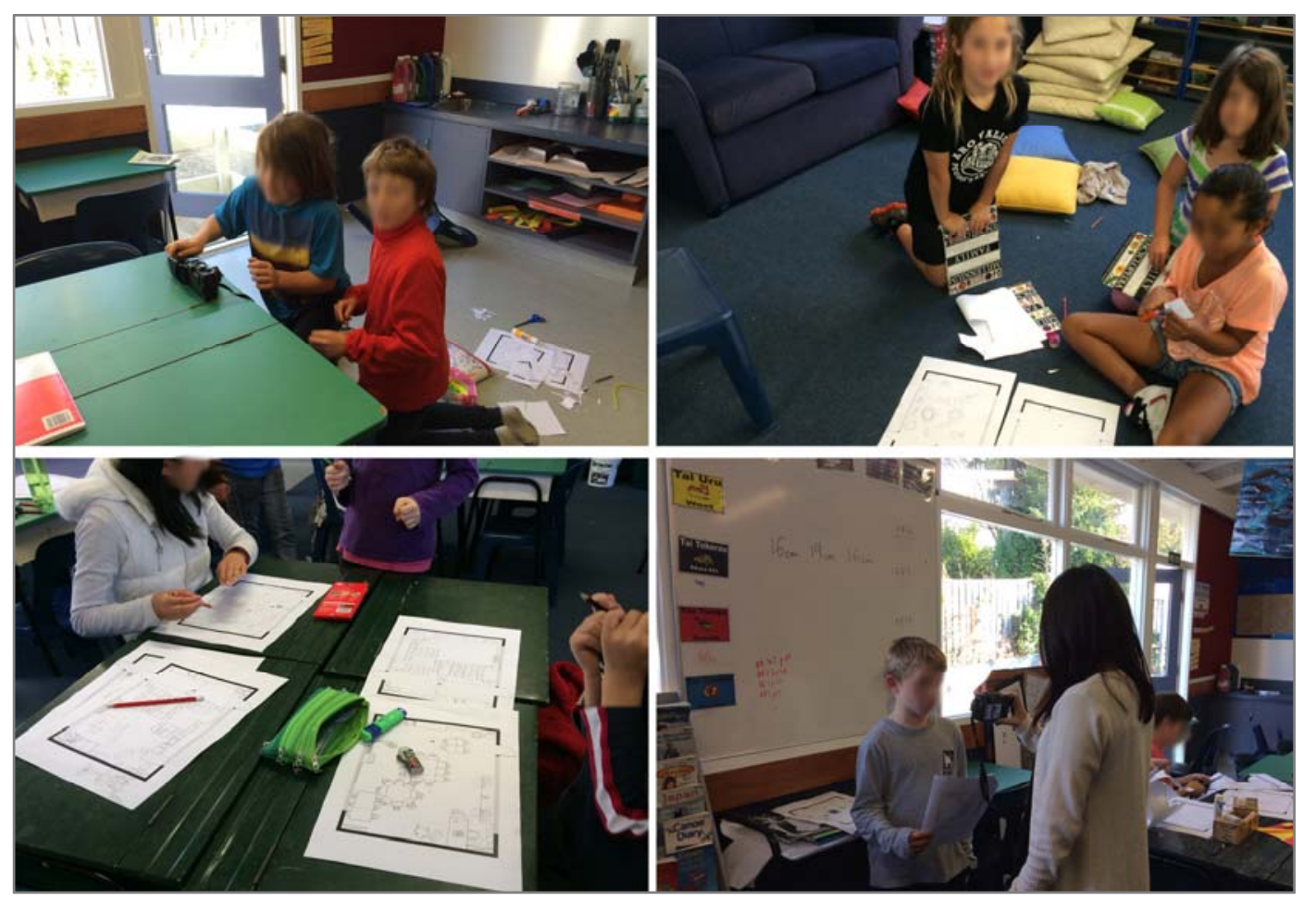

Figure 7-22: STUdents in the WORKSHOP, Te ARo Classroom.

Students produced two pieces of written work, one voice recording, two videos, and nine completed drawings (Figures 7-23, 7-24). In the written work, students suggested changing the layout of the desks, getting rid of the broken computers, having a bigger reading area and more circulation space, as well as some changes in the overall layout (Figure 7-23). In the drawings, all students suggested changing the desk arrangement. Through their drawings they suggested having more furniture-free space than in the existing classroom layout. However, students who used the paper furniture to test out their ideas had less furniture-free space in the revised work (figure 7-24-C \& D). 


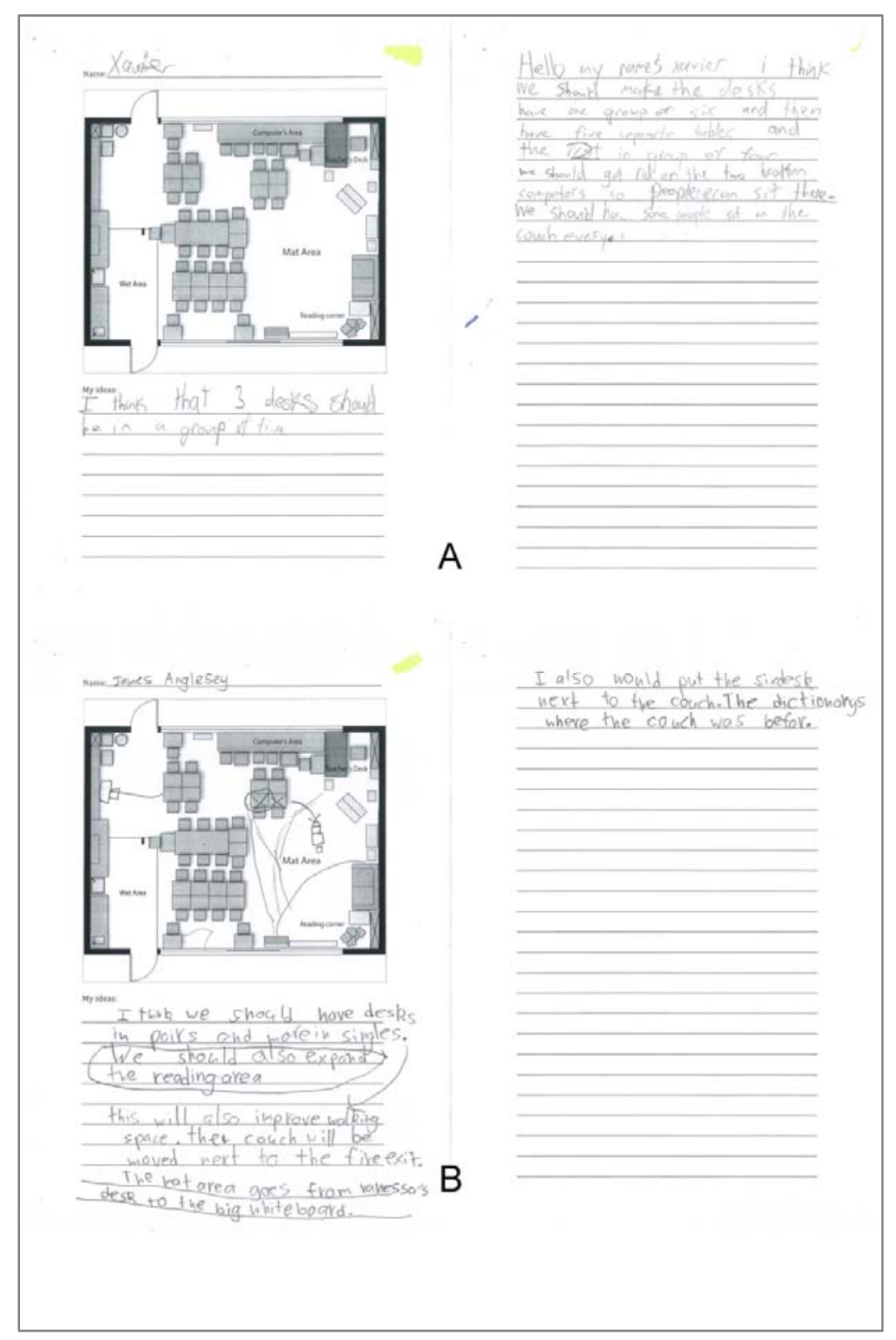

Figure 7-23: Written work, Te Aro Classroom.

In Figure 7-24-A the student drew the furniture at a similar scale to the actual furniture. So when he tested his work he achieved a similar layout (Figure 7-24-B). Most drawings did not change much in terms of the overall locations for settings. Some drawings suggested changing the teacher's desk to another corner between two mat areas (Figure 7-24-G). In general, the drawings focused on changing the desk 
arrangement. The voice recording and videos replicated the ideas in the drawings and written work of changing the desk arrangement and having more space for circulation. 


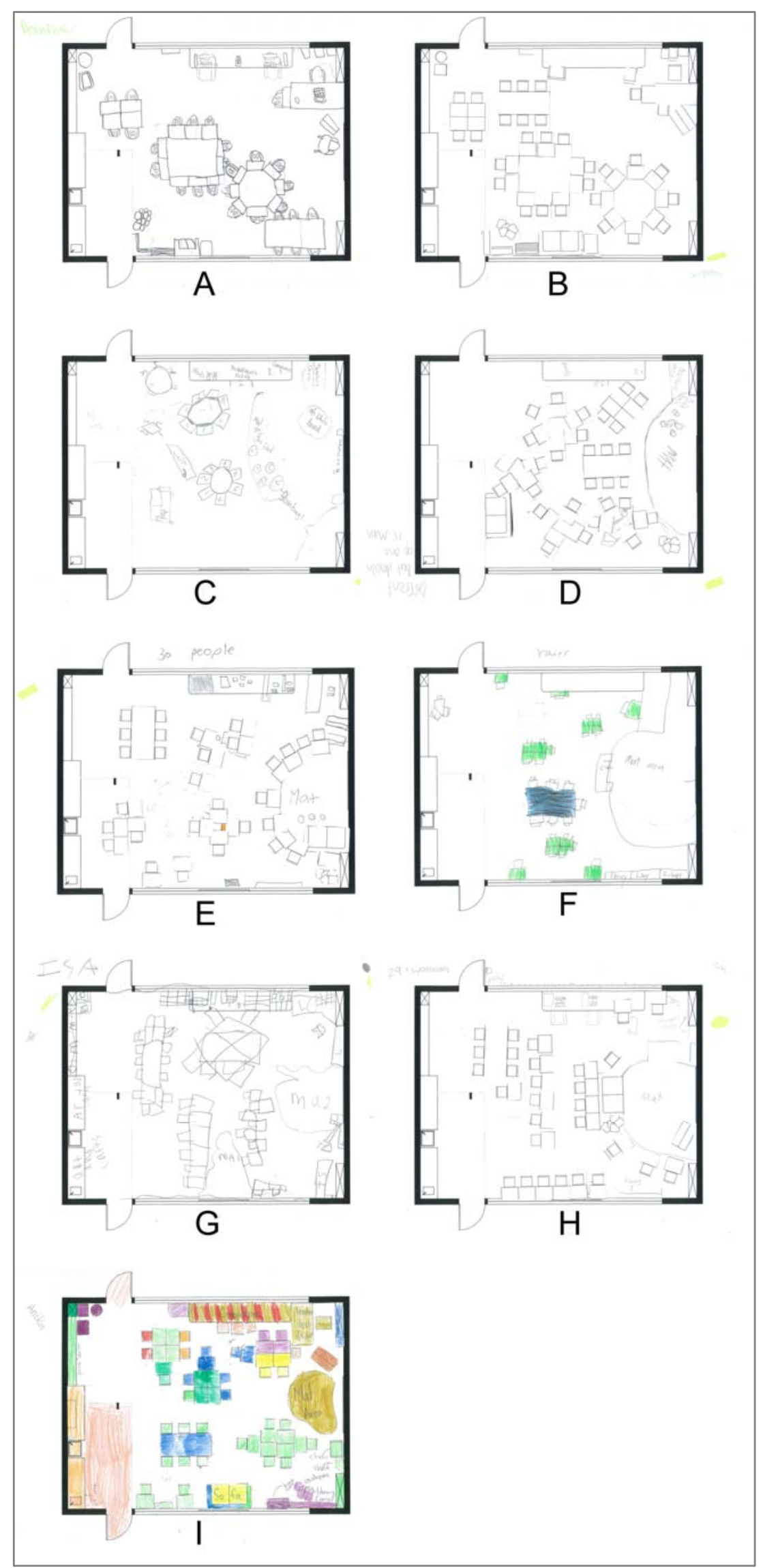

Figure 7-24: Drawings, Te Aro Classroom. 
In Thorndon Classroom, almost all students commented negatively on the existing reading area. Some students wanted a bigger space for this, and others said that there was no space for sitting and reading in the designated reading area. Others requested soft furniture such as beanbags and a sofa for it for comfortable reading. Students also commented on the art area. Some liked how spacious it was while others felt it needed some furniture. Some students said that it was big enough for all students, while others wanted more furniture-free space to play, at the expense of the art area. Students commented on the classroom tables, with some saying that the tables were boring and others that the arrangement of tables was crowded. Students requested more circulation space between tables. Other comments were about different things in the classroom. One student liked the room with lots of windows. Another student commented on the importance of having a teacher area in the classroom so the teacher can work privately.

As in Te Aro Classroom, the exercise was introduced after discussing the comments. The students were also excited to be part of this workshop. They were divided into groups according to the way they wanted to express their ideas. Most students preferred drawings as a way to complete the workshop, although some wanted to make voice recordings, while others wanted to record a video. None of the students wanted to write their ideas. However, after a while, when some students had finished their drawings, they asked for 
sheets to write down their ideas. Most students finished their work individually. Some students who recorded videos worked in pairs. Students used different settings of the classroom for this work, including the floor, art area, and desks, while others went outdoors to complete their work (Figure 7-25). Students had 90 minutes for the exercise.

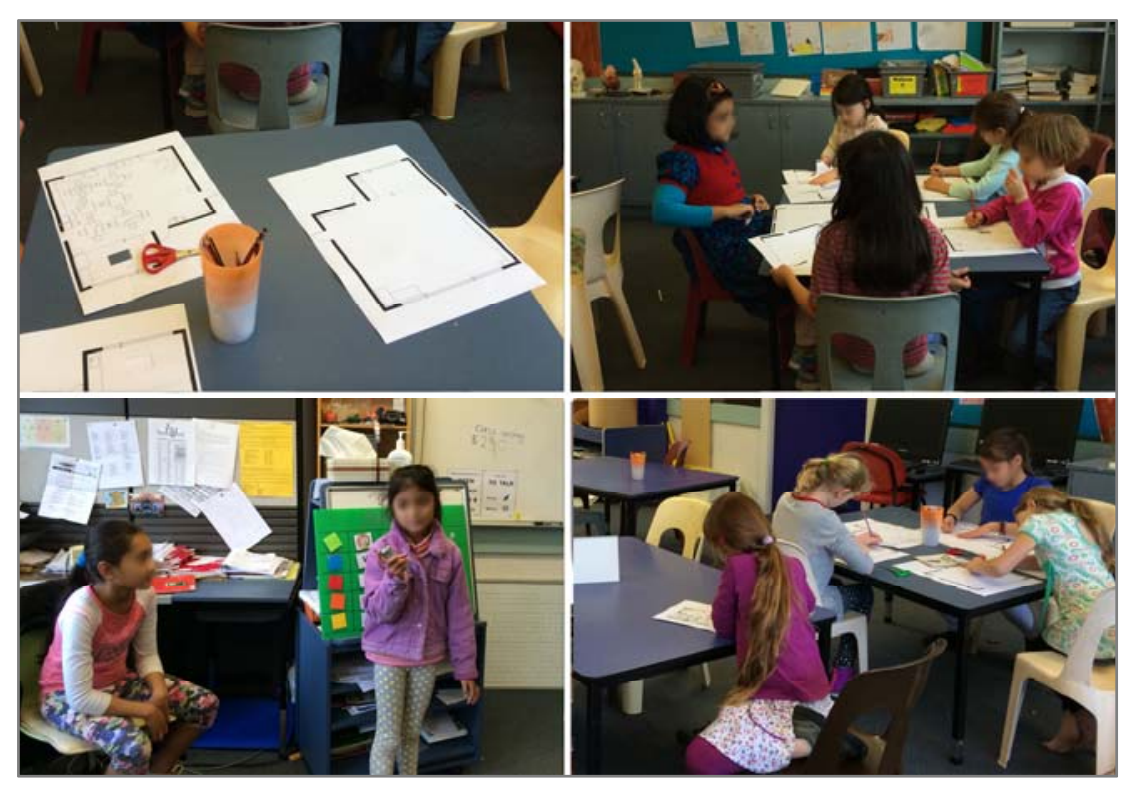

FIGURE 7-25: THE WORKSHOP, THORNDON CLASSROOM.

The students produced three pieces of written work, twelve drawings, three voice recordings, and four videos. In the written work, students suggested creating a bigger reading area, moving the tow-trays to the art area, moving the computers to better locations, moving the table from the art area to have a bigger art area, and adding a sofa to the reading area (Figure 7-26). In the drawings, most students used furniture locations that were similar to the existing ones. Three drawings almost copied the original floor plan layout 
(Figure 7-27-A, B, \&L). Three other drawings changed the table layout to be in rows (Figure 7-27-C, F, \&H). Two drawings suggested locating the classroom computers together in the same space (Figure 7-27-H \&K). The drawings were also about adding more settings, such as cushions and soft settings and a play area. Overall, the students could not manage to use an appropriate scale in their drawings. Only the students who used the paper furniture could present a true vision of the proposed classroom furniture. The students who completed the written work were the same students who created the voice recordings. Thus, the suggestions were repeated. In the videos, students also suggested changing the location of tables to create more space to move around the classroom, moving the reading corner to a larger area, and grouping the computers together. 


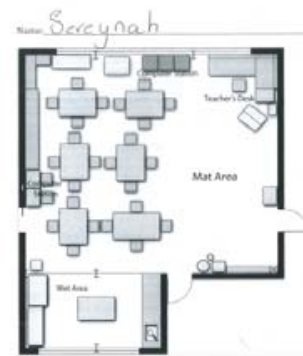

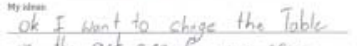
And the compresestation now to the

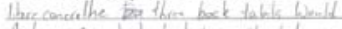
dicke up a bit bit ons soeved be

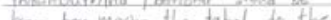

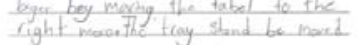

A

to whor the at anea. So yeh

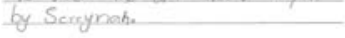

$\left[\begin{array}{lll}\text { Hazel } & \\ \hline 0 & 0\end{array}\right]$

$\left[\begin{array}{lll}0 & 0\end{array}\right.$

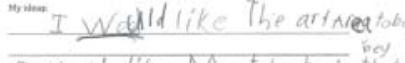
I would like Mat to be in the to

B
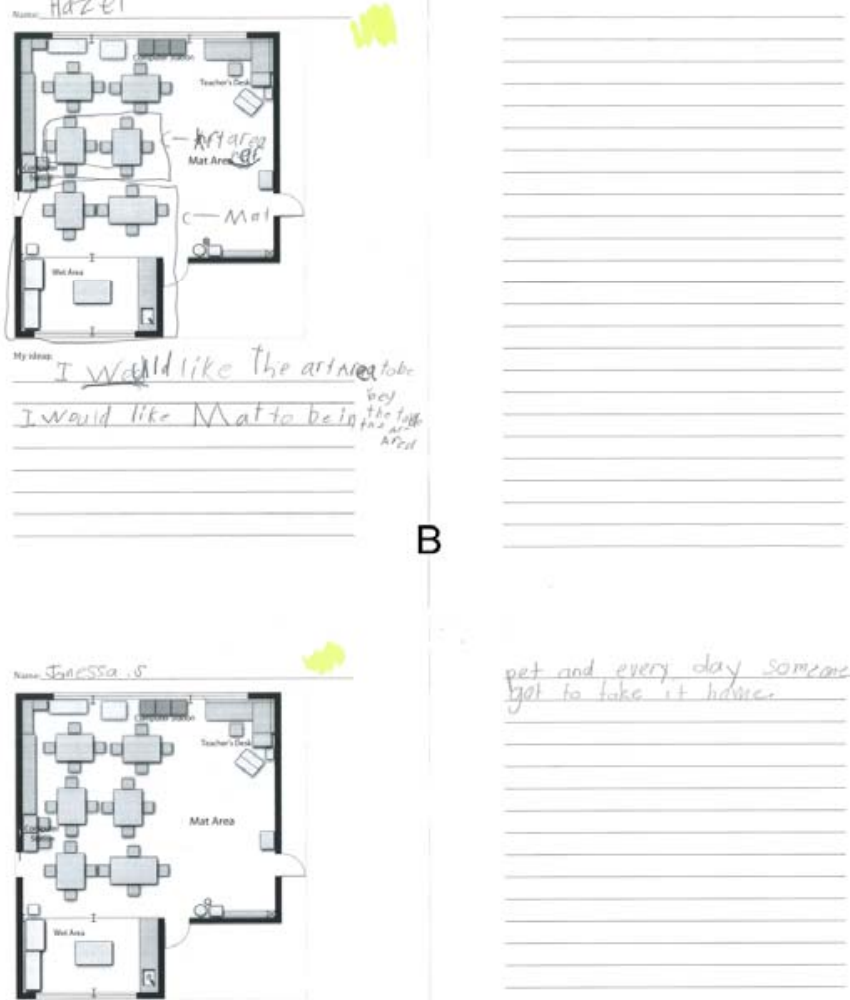

witwish that we parul move the the fot replace the tode nar bam 2.3 dono We cout went-p a a sola at the liwan$$
\text { and read. wish ne lad a class. }
$$

C

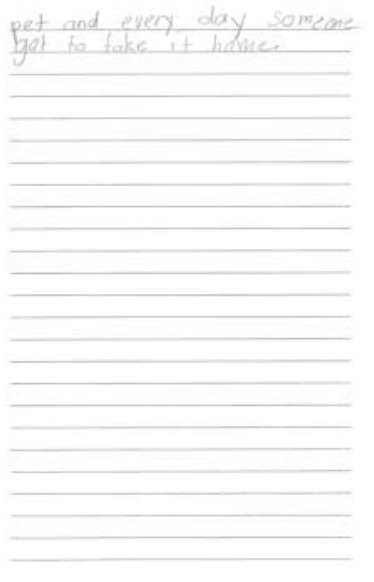

FIgURE 7-26: STUDENTS' WRITTEN WORK, THORNDON CLASSROOM. 


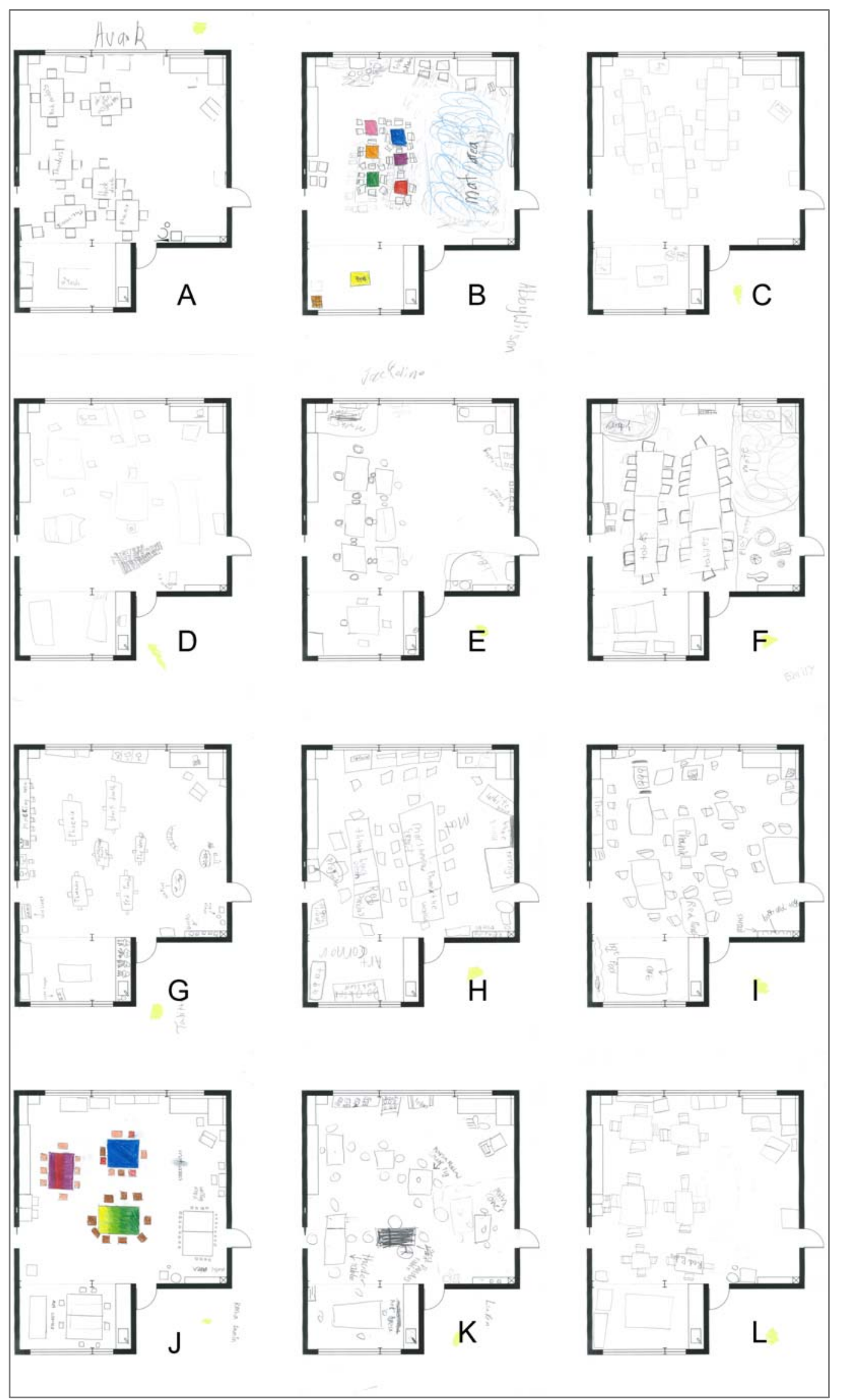




\subsubsection{THE FINAL DESIGN STAGE}

In the final design visit, the ideas and comments from the last session, drawings, written work, voice recording, and videos in both classrooms were first discussed in a whole classroom session, including the teacher and researcher. Then, a discussion about the final layouts in each classroom took place. For this a floor plan of each classroom with only the fixed furniture and features was provided, together with the movable classroom furniture cut out of pieces of cardboard. The discussion was in the form of a consultation, where the architect (the researcher) consulted the students and teacher about the location of each zone and piece of furniture and the placed the cardboard cut-outs to create a series of options. This was the point at which the issue of scale was discussed. Students became especially aware of this problem at this stage, because of the use of the scale cardboard cut-outs. As some students suggested ideas for the layout other students and the teachers voted for the ideas they liked. This part was important, as the researcher wanted to express how all users should participate in a decision. The architect also gave opinions as an 'expert' on the design of spaces. The last part of this stage was moving the furniture cut-outs to create a final layout based on the suggestions from the students and teacher. The sessions were completed inside the classrooms in the afternoon. 
In Te Aro Classroom, the main comments and ideas from the previous stage for the Te Aro Classroom were about having more space for the mat area, changing the layout of the desks to a curved arrangement, and having a less crowded classroom.

One important change was to arrange the desks in a semicircular shape so all students could be in one large group. Others concerned changing the library/ reading corner according to the students' drawings and ideas and creating more space around desks and other furniture. The architect (the researcher) suggested creating a corner for quiet study and the students were excited to have such a space. Students suggested having the teacher's desk in another corner, as indicated in Figure 7-28. The teacher did not express any opposition in front of the students. However, after finishing the session with the students, the teacher requested that the desk remain in its original location. The researcher argued that it would be difficult to offer a reason for changing the desk back to its original place thus ignoring the students' suggestions. The importance of the students' voice was reiterated, as the aim of this phase of the research was to observe student involvement and participation in changing the design of their own environments.

The final floor plan was designed based on the students' requests and suggestions on the cardboard plan. The desks were placed in curved shapes, as suggested by students. 
Other corners, such as the teacher's desk and the library corner were also to be exactly as students suggested. The researcher completed the floor plan with the pieces of furniture that students did not decide where to place because of the time limitations. The couch was placed next to the library corner, as a number of students had expressed that they use the couch for reading (Figure 7-29).

For the actual rearrangement the researcher, with the help of friends, changed the furniture layout of the classroom one evening. This rearrangement work did not involve working with the students and the teacher at the request of the teacher.

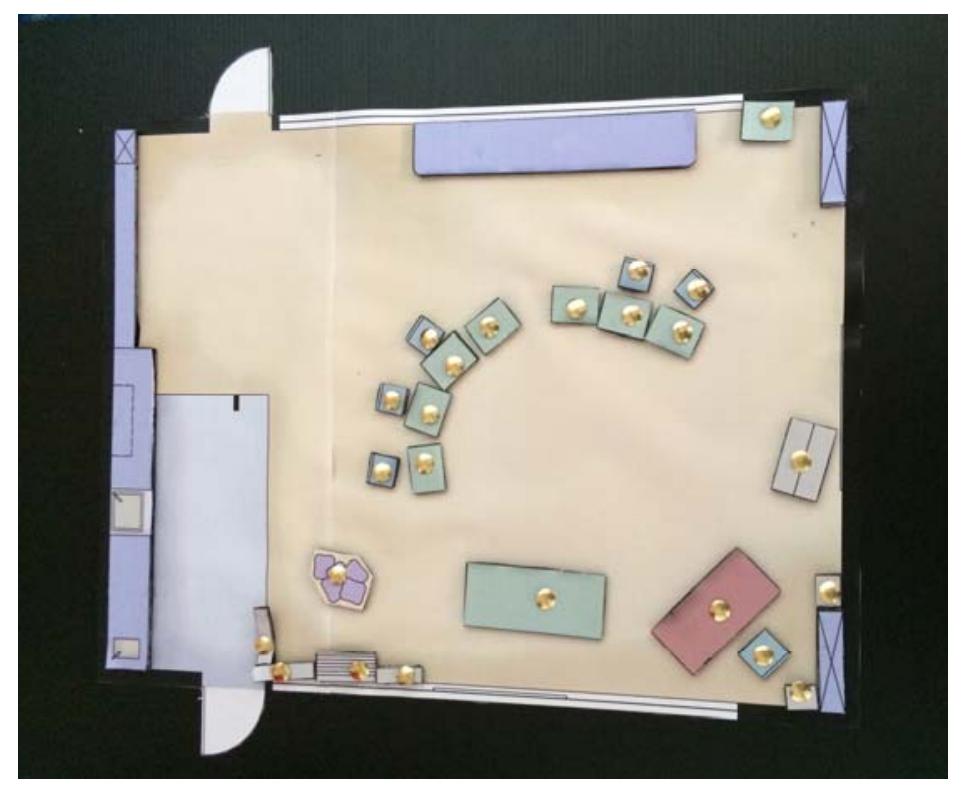

FIGURE 7-28: THE CARDBOARD LAYOUT CREATED AT THE FINAL Design stage, Te Aro Classroom 


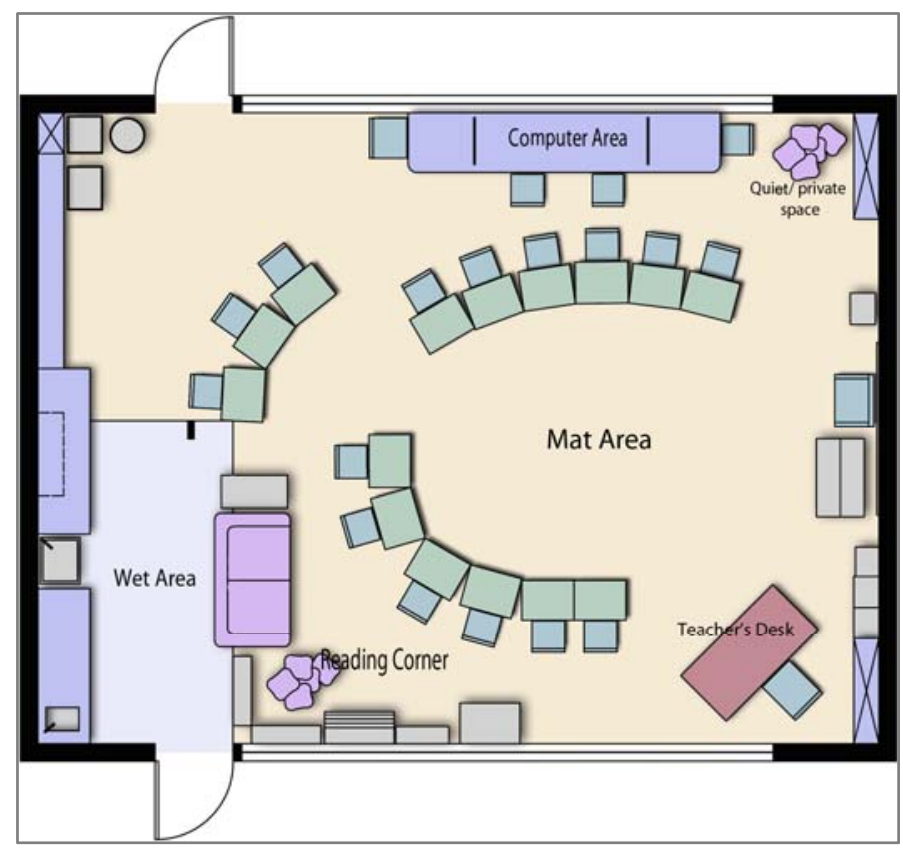

Figure 7-29: The final layout, Te Aro Classroom.
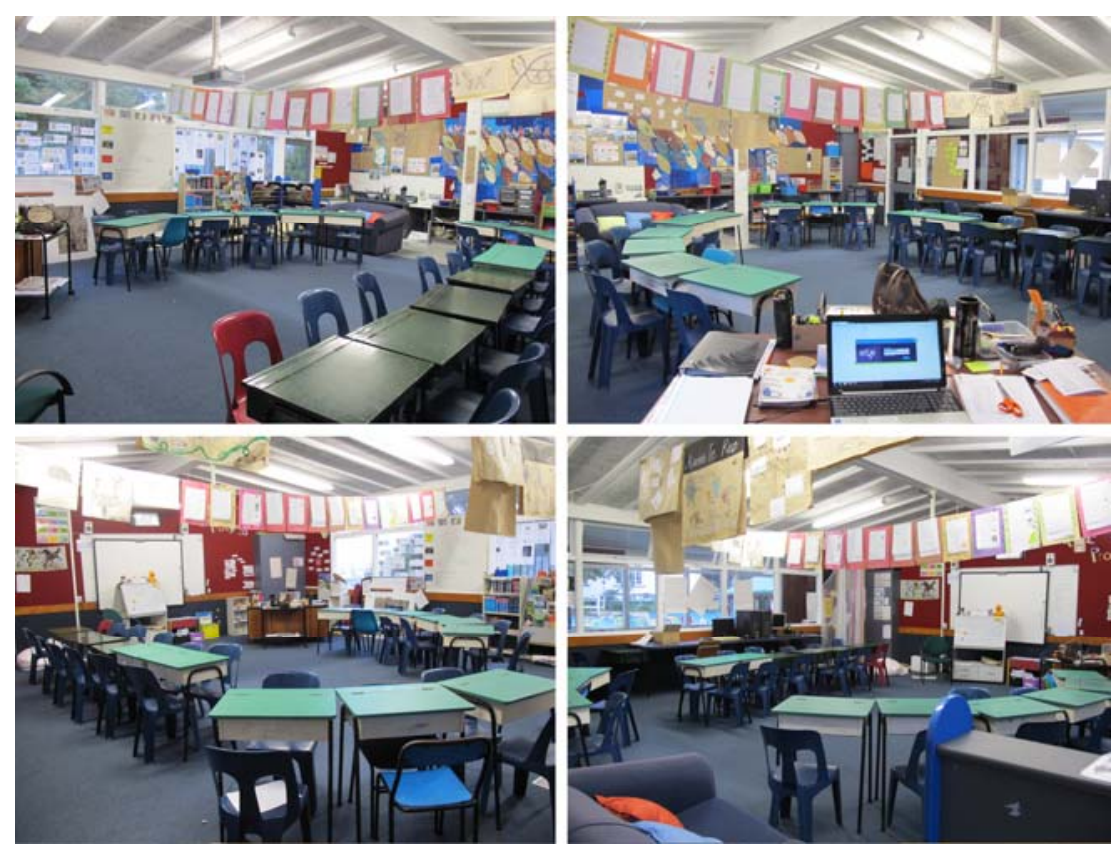

Figure 7-30: Photographs of the final layout, Te Aro

Classroom 
In the Thorndon classroom case study, the main comments and ideas from the previous stage were about having more free space for the mat area, having more space between tables so as to move about the classroom easily, arranging the tables in lines, putting the computers together, and creating new activity zones such as a reading area.

The important changes to the cardboard cut-out layout were to put all computers together to create one computer station, to arrange the tables in lines in response to some of the student drawings and ideas, to create a bigger reading/library corner, and to create more circulation space around tables and other pieces of furniture. As for the Te Aro Classroom the suggestion of the 'architect' to create a corner for quiet study was greeted by the students with excitement.

The researcher converted the cardboard plan into a real digital floor plan through drawing the same arrangement suggested by the students. Almost all furniture was discussed and located on the cardboard plan. The only difference between the cardboard plan and the final one is the computer station. Both students and teacher suggested putting them all together next to the teacher's desk unless the computers could not be place together for technical reasons. After providing the needed wires and equipment, all computers could be placed in one area (Figures 7-31, 7-32).

The teacher wanted the students to be involved in the rearrangement and to move the furniture with adult help (the researcher and the teacher). The students were divided into 
four groups, and each group had to rearrange one area of the classroom. Students were excited about moving the furniture and creating a new classroom layout.

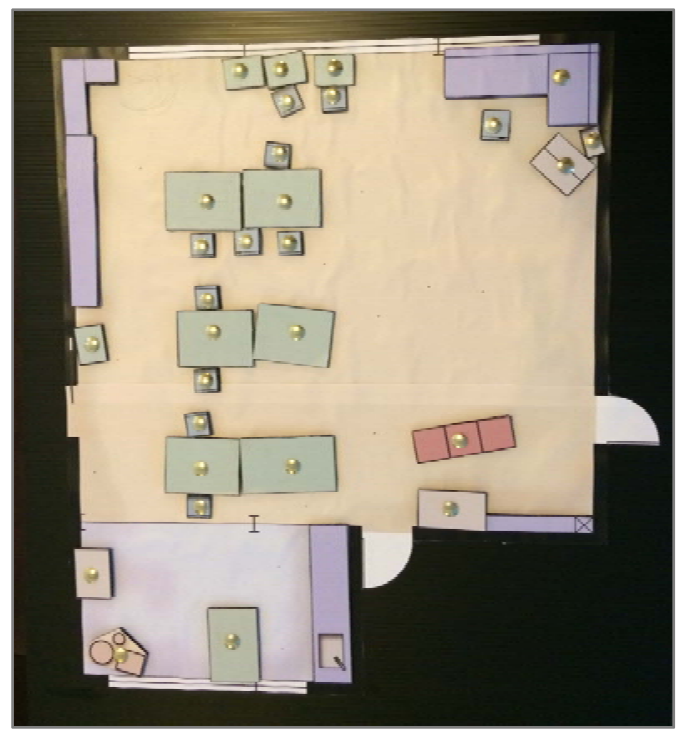

FIGURE 7-31: THE CARDBOARD LAYOUT CREATED AT THE FINAL Design STAge, ThORndon Classroom 


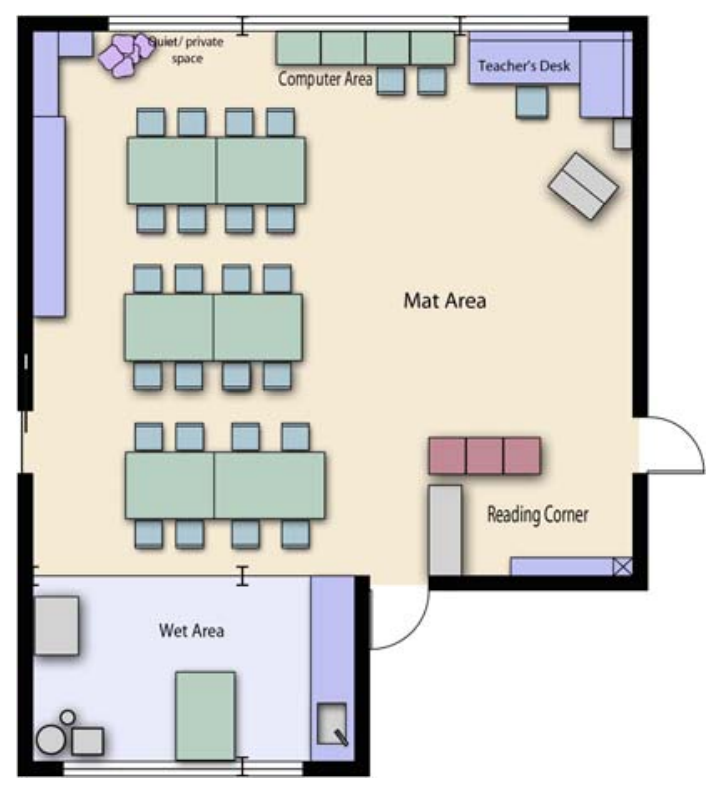

Figure 7-32: The final layout, Thorndon ClassRoom
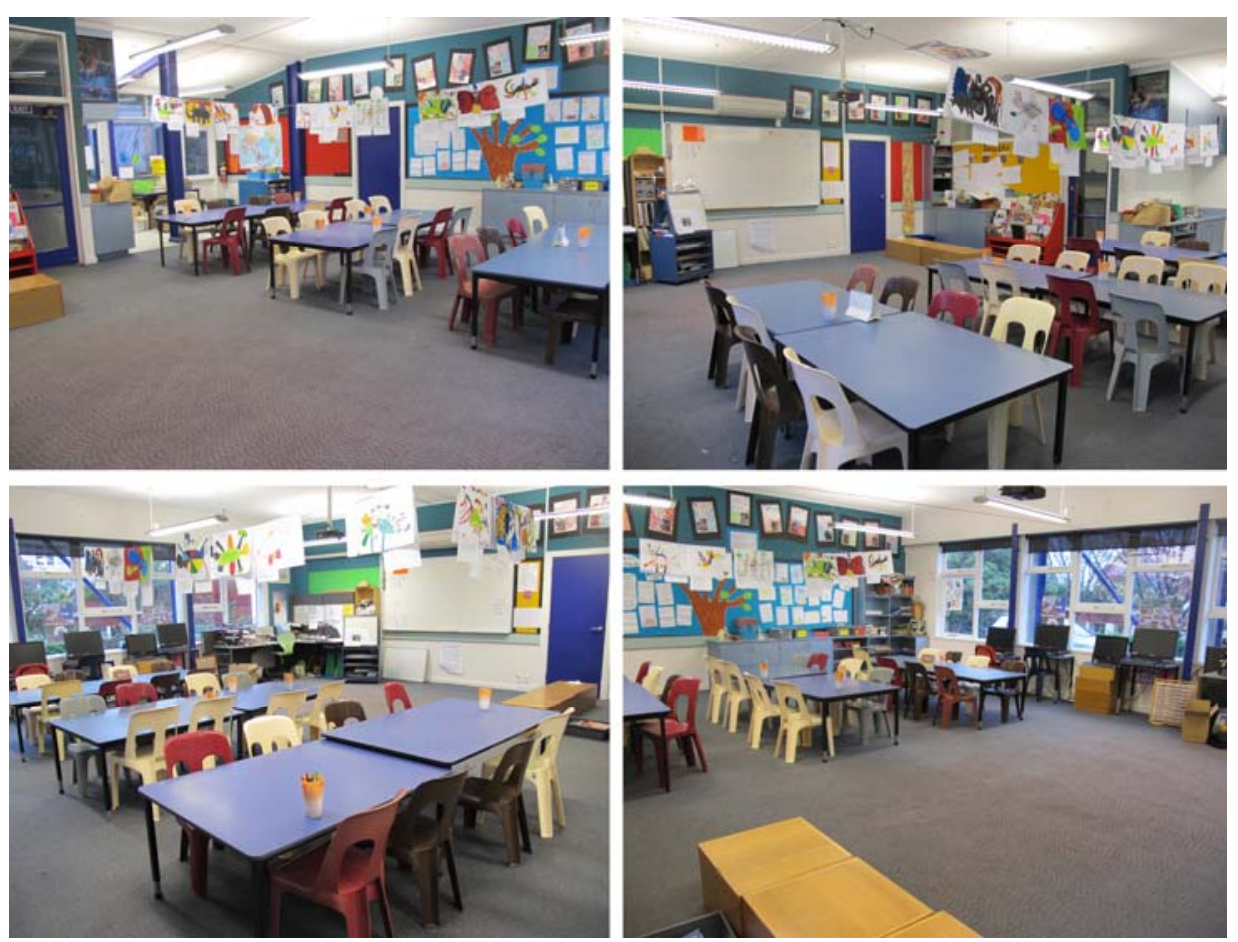

Figure 7-33: PHOTOGRAPHS OF THE FINAL LAYOUT, THORNDON ClassRoom 


\subsubsection{FEEDBACK AFTER THE FINAL}

\section{REARRANGMENTS}

For the last stage of this case study, a final visit was made to each classroom. The process of changing the furniture layouts was discussed in these visits. A short presentation including photographs of students working on this case study was given and discussed with students. Finally the students and the teachers were given a feedback sheet that asked for their opinions of the new layout (see appendix J). The feedback sheet for students consisted of a floor plan of the old furniture layout, a floor plan for the new furniture layout, three questions and a space for general comments. The questions were "What are the two things you most like in the new classroom layout? What are the two things you most dislike about the new classroom? Do you like the new classroom layout more than the old one?" The teacher's feedback sheet was the same, with the addition of a question about whether they were going to keep the new layout. For this last question they had three choices: "yes with no changes; yes with minor changes; or no". The students and teacher had one week to fill out the feedback sheets.

In the Te Aro Classroom, the teacher liked how the fewer desks made the classroom more spacious. She also liked how students were involved in the process of changing the furniture layout. She said that the students became more responsible for their learning environment. She disliked how the reduced number of desks meant students had to share, 
which sometimes made it hard for students to focus on their work because they were sitting so close to each other. The teacher liked the new layout more than the old one and she said she would keep it, with some minor changes.

Students liked the new curved layout of the desks, the location of the teacher's desk facing the students' desks, the computer station, the big space created by the new layout, the private/quiet area, and the reading area. Students liked sharing desks, as they could share ideas and sit with their friends. The things that students mentioned most in their likes were the big space created by the new layout for the mat area, the layout of the desks, and the position of the teacher's desk (which the teacher had tried the change). Students did not like the fact that in the new layout some pieces of furniture were still squashed together, such as the chair and couches of the private/ quiet area, and some areas, such as in the reading area, were still crowded. Some students did not like sharing desks. Out of 21 students who filled in the feedback sheets, 5 students did not like the new layout more than the old one, and the rest liked the new layout more than the old one.

In the Thorndon classroom, the teacher liked the space that the new layout created. He also liked how the students had responded to the new layout, as they seemed to work well with it. He disliked the fact the boxes used in the library area (for seating) were distracting and that the computer area became crowded with having all the computers in the same area. He liked the new layout more than the old one and is 
planning to keep it with some minor changes, such as changing the computers back to their original positions.

The students liked the new art area, the computer station with the four computers together, the table arrangement, the library corner, and the private/quiet study area. The things that students mentioned most in their likes were the new table arrangment, the new library corner and the private/quiet area. Almost all students disliked the new locations of the rubbish bin and the tow-trays. Some students did not like the new location of the computer area, as the computers are now too close to each other. Some students said that they like everything and had no dislikes. Out of 23 students who filled in the feedback sheets, only 2 students said they did not like the new layout more than the old one.

\subsubsection{PHASE FIVE DISCUSSION}

In the exploration stage, there were two different situations in the two classrooms, as one had been involved in a layout rearrangement in term 1 while in the other nothing had been changed recently. This difference gives the opportunity to compare the two situations of working with students in the new rearrangement. The two teachers were different in their responses toward involving students in taking the classroom measurements. This could indicate that one teacher cares more about involving students in the design process so they can learn more, or it could be that one of the classroom schedules was busier than the other. Having a teacher who is 
enthusiastic about involving children in the design process may be a key step in having a more collaborative design process.

In the brainstorming sessions, the two sets of students had similar responses to defining a classroom, which may indicate how students see and perceive the environment around them. Although some students from both classrooms did not care about having a mat area or disliked the mat area, the majority liked having this feature, which shows the importance of both the floor and having furniture-free spaces inside a classroom. The majority of students in both classrooms liked the modern classrooms with specialized corners. Students from both classrooms liked having different settings for different activities, which represents how students like to learn in different ways and that they have different needs inside the classroom, as the theory of multiple intelligences argues (Armstrong, 2009). Students could read and understand the floor plans of other classrooms as well as the floor plan of their own. This information reaffirms one of the main results of the social media posts, which is that students are able and ready to be involved in any design process related to their environments.

In the rearranging workshop, the number of students in the Thorndon Classroom was more than in the Te Aro Classroom, and the Thorndon students also produced more drawings. However, this may reflect the fact that some Te Aro students had less time than others for the exercise, although it did seem 
that students in the Thorndon Classroom appeared more excited about the workshop than those in Te Aro. In both classrooms, students suggested changing the arrangement of tables and desks, possibly indicating they were not comfortable with the existing arrangements. However, it could also be indicative of students becoming bored with an arrangement if it remains unchanged for a while. Students may need to change the layouts of tables and desks even if these are in a good arrangement, as occasional change could create more excitement in the classroom. In both classrooms, not all students used the paper furniture provided. It seems they prefer drawing more than cutting and pasting. This affected the scale of the furniture in the drawings, meaning some of the layouts were unrealistic. The problem of scale was discussed with the students before the workshop and later at the final design stage.

The fact that most students in the two classrooms chose to draw as a way to express their ideas may indicate that drawing is the easiest method for students. It also may indicate that students can express their design ideas through drawings better than in any other way. This is, after all, the way architects work. The replicated furniture arrangements in the Thorndon Classroom may suggest some students are tentative about designing classroom layouts. This copying issue did not happen in the Te Aro Classroom, but this might be because they had completed a layout design exercise with their teacher before these case studies. Each student's work 
was not discussed individually in detail. The intention was that the work would be discussed by the teacher and students to decide which ideas they could agree on and which could be applied in the final design. However, the researcher, as the architect, did discuss the ideas with the students at the final design stage in order to give them the architect's experience of the design process.

In the final design stage, using cardboard furniture and a floor plan worked very well in simplifying the scale issue for students. By trying different layouts with the cardboard furniture, the 'architect' convinced the students that they needed to think about scale in their designs. Students learned about scale and how the drawings cannot be applied unless they reflect the actual scale of the furniture.

The final layouts in both classrooms reflect student ideas from the previous stage. Students liked this, and they felt that they had designed their classroom themselves. Students also liked that everything in the final layouts had been voted for. Students learned that sometimes their ideas could not be applied because other students did not like them and did not vote for them. The whole process was collaborative, as everyone, including the teacher and the architect (the researcher), had a say in it.

The two teachers of the classrooms had different attitudes towards student's involvement. The Te Aro Classroom teacher did not get involved in the decision making while discussing the final layout. The researcher tried to involve the 
teacher in the voting but the teacher remained passive or just said that she was fine with students' decisions. But this attitude changed once the session with the students was finished. The teacher then requested some changes, such as keeping her desk in its original place. Thorndon Classroom teacher got involved and helped the researcher in controlling the student votes. The teacher liked all the students' suggestions, or at least he wanted the students to experience making decisions about their environments and testing these decisions. These different attitudes from the two teachers may reflect their own personalities in working with children. These attitudes will obviously affect the involvement of students in the design process either positively or negatively. Students need to get direct feedback about their ideas and decisions for their involvement to be successful (see section 3.3.1).

Involving students in the actual furniture rearrangement in the Thorndon Classroom made the students feel more related to their learning environment. Students also noticed the scale issue while moving the furniture. They also understood why they needed to design the layout on paper at a smaller scale before changing the classroom layout, as it is easier and they can try more options on paper than in the actual classroom.

In terms of feedback from students and teachers, the new layout might be not better than the old one in some students' eyes; however, they experienced how they can change the 
layout, how the classroom can be changed and that they can change the layout to reflect what they like. They also learned how to make collective decisions. From students comments on the feedback sheets, most were glad to have been involved in such a process. They thanked the researcher many times.

\subsubsection{PhASE Five CONCLUSIONS}

As an answer to the question underpinning this phase of the research, "Would involving students in a design process change their perspective of the learning environments?", the case studies showed how students like to be involved in a design process. Students learned many things about their learning environment by completing the design process of rearranging the furniture of their classrooms. Students could deliver ideas in the ways they found best. The design process also had a positive effect on the students' attitudes toward designing learning environments. Students learned many things about the design process and perhaps the most important thing they learned was that they had the right to talk about their ideas. They learned that their ideas could be applied in the real environment if they were suitable and other users agreed with them. Students learned how to think about their needs and how to design layouts that would meet these.

\subsection{COnCLusions}

The set of studies in this chapter provide a series of findings that contribute to widening knowledge about the design process of learning environments in New Zealand. One 
conclusion from these studies is that using a certain type of media in different situations might give different results. The experiment with using social media in the second phase did not work as planned. However, using the social media in phases four and five where there is a real project was involved worked well, or at least better than in the experiment, in involving users in the design process. Another conclusion is that involving users, especially students, in the design process of their learning environments can affect their attitude towards their environments. When students worked in changing the layouts of their classrooms in phase five, the final designs reflected how well the students understood their environments after going through the different stages of the project. The last main conclusion is that users were keen to participate and become involved in the design process of their learning environments but that they need suitable media and methods with which to accomplish this participation. Guidelines from the Ministry of Education could simplify this participation, as the Ministry can reach and supervise all school projects. 


\section{CHAPTER 8: DisCUSSIONS AND CONCLUSIONS}

At the beginning of this thesis, a literature review was undertaken looking at the history and design of learning environments and specifically those for primary school aged children. It also covered participatory design in learning environments, and the current situation and design of learning environments in New Zealand. This review revealed a lack of studies about learning environments in New Zealand, and despite support for the idea from the Ministry of Education, a lack of user participation in designing these. This led directly to the aim of the study, which was:

To create an understanding of the design process behind primary school classroom learning environments in New Zealand.

In turn this produced a two part main research question:

What lies behind the design process of the current layouts of New Zealand primary school classrooms? How, if necessary, could the design process be improved for better perceived learning outcomes?

This chapter aims to discuss and compare the results of the five phases of the research that were established to meet the aim and answer the research questions. The results will also be compared with findings from the literature review. 
Chapter 8 has two main sections. The first, with seven subsections, focuses on the discussions of different findings in this thesis. The first sub-section concerns the design of learning environments in general and especially their interiors. The second compares the examples of relevant participatory design in New Zealand to the studies discussed in the literature review. The third sub-section is a further discussion of participatory design methods and how they might be applied in New Zealand. The fourth sub-section discusses what the Ministry of Education could do to improve the design process and encourage more participatory design in learning environments in New Zealand. The fifth subsection answers the main questions of the thesis and the last discusses the limitations of this study. It also suggests opportunities for further research.

The second main section in this chapter discusses the main conclusions of the research.

\subsection{DISCUSSION OF RESEARCH FINDINGS}

The following subsections attempt to connect all the research findings together. The main references are not repeated here as they have been given throughout the thesis.

\subsubsection{LEARNING ENVIRONMENT INTERIORS}

Classroom design has an effect on both the learning outcomes of students and the teaching strategies of their teachers. Ideally learning environments should support different teaching styles by having appropriate settings that facilitate application of the elements of different educational theories 
and teaching styles. As discussed in section 2.2.3, theories such as multiple intelligences need special settings to encourage students to express their strengths in different ways. Thoughtfully designed learning environments could also have a positive effect on improving student behaviour towards learning and this could result in better learning outcomes. Studies overseas confirm this information and indicate that schools in other countries do apply this knowledge in the design of learning environments. However, in New Zealand there are no studies that focus on the connection between learning environments and learning outcomes. The focus of New Zealand studies on classroom design is mainly on environmental aspects such as air quality and acoustics. This is not that say that these aspects are not important. The history of schools demonstrates that these issues have been considered for many years, even leading to extreme examples such as open air schools (see section 2.1.1.4). However, what seems to be missing is the important link between acoustics, lighting, air quality, and other environmental elements and the way these directly affect the activities completed in classrooms. For example, classroom lighting should be designed to be suitable for different activities such as reading and writing, drama activities, and watching videos on data projectors or TV screens. Each activity needs a certain level of lighting and the children in this research were well aware of this, given their comments on wanting natural light but also having problems with glare on the white board (see sections 7.1.4.1 \& 7.4.3.3) Other 
environmental aspects need the same attention. The argument is that the focus of studies about learning environments in New Zealand should be on other elements in addition to environmental aspects.

Studies also need to cover the internal layouts of learning environments and the relationship between these layouts and student learning. Studies overseas are useful in this respect but there is a need to make sure that the layouts serve the New Zealand national education curriculum. Another problem is that the school designs in New Zealand that are held up as good architecture focus on the exterior of school buildings, libraries, the administration office, and reception and halls more than the interiors of classrooms, despite the fact that classrooms are where children spend most time over the school day. One way of ensuring good classroom environments might be to make these the focus of architecture, although here another problem emerges in that classroom furniture is not something over which architects have control. Because classroom layout and furniture have a dependent relationship this is an area of the design process that needs rethinking, perhaps led by the Ministry of Education.

From the different phases of this research it is clear teachers recognize the importance of having good learning environments for better learning outcomes. Thus the answer to the sub-question from section 5.2, "Do teachers see a relationship between classroom layouts and learning 
outcomes?" is "yes" as they see a strong connection between learning environments and learning outcomes. The data also show that teachers who have experienced working in different learning environments especially recognized the relationship between learning environments and learning outcomes (see section 6.2.5). They also noticed how the different layouts and settings in different learning environments changed their teaching styles, and this in turn affected the connection between teachers and students. However, it is evident from the sample that teachers try to create the best classroom layouts to support their teaching styles but it seems that they only have control over the furnishings. In their answer to the sub-question from section 5.2, "Who sets out the classroom interior and how and why do they make choices?", teachers indicated that the classroom designs are a combination of the work of architects, school principals, the Ministry of Education, teachers, and in some cases, students, although they felt the main influences on the overall design came from the first three parties in this list. Initially, architects appear to work with the school principal and members of the Ministry to create the floor plans, and only occasionally are teachers and students involved in this stage. There is evidence that teachers, sometimes with their students, change the internal layouts while they are using the learning space but this is a normally a rearrangement of existing furniture and equipment because of budget restrictions. 


\subsubsection{Participatory design in NeW ZeAland LEARNing ENVIRONMENTS}

Participatory design is an important element to be considered in any design process. Knowing what users need in a design is a major aim when it comes to designing any product or space that people will use. With participatory design, not only are the user needs investigated, but the users themselves work with the designer to make sure these needs are met. In learning environments, the user needs vary from country to country, school to school, classroom to classroom, and even inside one classroom. As these learning environments serve a young age group with developing and changing needs it may be that user participation is very important for this group. Studies discussed in chapter 3 emphasise the importance of involving children in designing their environments so as to make them linked to the spaces they use and inhabit.

For New Zealand learning environments, although the guidelines provided by the Ministry state the importance of user participation in design projects, there is no strong encouragement for this to happen or resources provided that show how it might be successfully accomplished. This study clearly shows that student users are not heavily involved in the design process. User participation is often mentioned in relation to projects, but the details of these indicate that the involvement was not completed properly. For example, in the examples of modern learning environments (see section 4.2.3.1), user participation was mainly by consulting teachers, and only in some cases children, about the designs. These 
consultations in themselves might not be enough to qualify as proper participatory design. Consulting users may mean presenting the final designs after the decisions have been made. According to Parnell (2014), consultation is an inadequate method for participation. Participation needs to be a process of social learning, as well as being focused on designing a certain space or product. In this way children learn to become empowered. Good participation methods should include those who are experts in their own environments-the users (Parnell, 2014). In participatory designs users should be involved in the different and appropriate stages of the design process. Ideas should be generated from the users, not presented to them. Users know what they really need and what would work to meet their needs. This does not mean that designers might need to direct user ideas to what is architecturally appropriate, but this dialogue is an essential part of any participatory process. The sample of architects in this research were in support of participatory design (see section $6.3 .2 \& 6.3 .3$ ), but they also felt that budget and time restrictions made this difficult for them. This again comes back to the Ministry, as if they support this approach then the budget needs to be appropriate for ensuring it can happen.

Also, in the phase three case study the involvement of teachers and students did not seem to be well-designed. Teachers felt that they were not involved enough, while the school principal thought that their involvement was adequate 
and they were too busy to be involved more. Students were involved through the display project, which worked very well for what the school principal had planned. In the display project, the ideas were presented to users and they mainly needed to comment on these and recommend what they liked or disliked. Again, ideas were not generated from users, which made it consultation more than participation. In this case study the teachers, as users, would like to be have been more involved in the design, even at the master plan stage. They believed that their involvement, together with that of their students, would create better learning environments that would meet their own and their students' needs. This gives a positive answer to the sub-question in section 5.2, "Do teachers assume it would be better if users (teachers and students) were involved in the design process of learning environments?"

When it comes to the detail of classroom layout, it seems teachers do not even choose the furniture they have to use in their learning environments. They may make suggestions about furniture, but the main decision, as their survey revealed, is usually made by the school principal (see 6.2.2 \& 6.3.4). However, teachers do have a say in arranging the furniture inside the classroom or learning environment. This means the answer to the sub-question (see section 5.2), "Do teachers have options for selecting classroom furniture and the subsequent internal layout?" is that they have little control over furniture selection but they do control the internal 
classroom layout, which includes this furniture. This is not, perhaps, an ideal situation.

Students, on the other hand, seem to be less involved in either the design or the arrangement of their learning environments. However, when the opportunity to participate in the latter was offered to them they engaged with the process and were positive about the results (see 7.3.4.6). However, just as principals seem to take over the architectural projects and leave little space for teachers and students to participate, teachers may also take over the design of the internal layout and leave little space for student involvement. Leaman and Bunn (2014) posited that when decisions are made by principals or head teachers, they tend to have a power image of the building. They might discuss having flexibility in the building but applying this might not be successful. For example, principals may suggest having partitions to divide spaces for more flexible learning environments but these partitions could be too heavy for the users, especially student users. Principals might not know about the difficulties of using these partitions, as they are not using them as students and teachers do (Leaman \& Bunn, 2014) but it also sends children the message that adults are in control of their environment. Parnell (2014) claimed that students learn a lot by participating in the design process of their schools. Architectural education could be introduced into schools by learning about design in a hands-on way through rearranging the classroom. This kind of education could contribute 
positively to the process of involving students in designing their learning environments (Parnell, 2014). Students produced excellent work when they were involved in changing the layout of their classrooms in phase five, and proved they could manage the layout of their learning environments to meet their needs, even when these had to be agreed by consensus or vote. The children were also ready to work with architects at the scale of architectural projects, and especially through drawings (see section 7.1.4.1 \& 7.4.3.3). Children understand many things about designing learning environments and design elements, maybe more than adults realise.

In addition to the architectural benefits of participatory design, there are a number of educational benefits. As noticed during working with students in both phase two and five in sections 7.1.4 and 7.4.3, students interact with the design of their learning environments in a very professional manner for their age. Students could recognise the different elements of their learning environments such as windows, doors, and partitions, in addition to the furniture layout configuration, which they could both propose and comment on. The exercises completed in phases two and five helped, and could continue to help if repeated in the future, to increase critical and analytical thinking in children. These exercises could be used not only for their architectural aims but could be studied and practiced for educational goals. 
In terms of the role of architects in the design process, the thesis has uncovered the lack of proper post occupancy evaluations. As discussed in section 3.5, POE should be part of a participatory design process. The evaluation depends firstly on the users' reactions towards built environments. In terms of learning environments, and as users change every few years as discussed in section 7.2.3, the architect's ideal role is to evaluate learning environments aiming to make them connected to the different generations that use the space. For example, in an existing school, the classrooms might be single cell using traditional furnishing (desks and chairs), outdated window treatments, and a specific colour scheme that could have been fashionable in the past. Architects evaluating such schools would give the new users a chance to express their needs through contemporary treatments. Architects could give suggestions on how to direct the maintenance budget into creating an up-to-date internal design to suit the users. The role of architects in POE was not discussed in detail in this thesis as the scope was limited to investigating the different stages of the existing design process of learning environments in New Zealand. Further studies could focus on the architect's role in improving existing school buildings.

\subsubsection{WAYS OF INVOLVING USERS}

This research has shown there are number of different ways of involving young students in the design of learning environments. What is needed now are monitored attempts 
to do this within the context of New Zealand schools, so that exemplars can be created for others to follow. These exemplars also need to be publicised rather than remaining as research findings. However, what this research has shown is that drawings, which are the medium of design, are a useful tool when it comes to involving students in creating environments. Drawing was one of four options, along with written work, videos, and voice recording offered in the classroom layout case study (see section 7.4.3.3). Students were attracted to drawing more than the other options, and this might be because it is easier for them to express design ideas with drawings than through the other options. Students showed they could draw good floor plans with respect to architectural elements such as walls, windows, and doors. They had problems with the scale of furniture in the drawings, as although scale paper furniture was provided, they liked to draw from their heads instead of using this. However, drawings need time and care if they are to be analysed properly so that useful ideas can be drawn from them. This is not the role of the architect. In the Thorndon School case study the principal assumed this role but the principal is not necessarily an expert in design issues. In the school garden participatory project (see section 3.3.2) and in the classroom rearrangement study in this research (see section 7.4) the analysis was done by an independent person with design skills (the researcher). This suggests that participatory design for children may require an independent facilitator with design skills to run the process. However, this 
may be hard to achieve within the currently available budget for new school premises.

Participation can also be achieved through direct communication with the teachers and students, which may be a cheaper route to take. This communication can take many forms, such as focus groups, brainstorming and discussion sessions, interviews, and meeting, and a number of studies provided examples of using these methods to design learning environments (see sections 3.3.2 and 3.4). However, the danger with this approach is it can too easily become consultation with children rather than true participation by children. It is evident in the New Zealand examples that participation is confused with consultation. Certainly consultation happens in school projects, and although it does not meet all participatory design requirements, it is a form of direct communication. Thus designers or architects, in addition to school principals, claim that they consult teachers, and in some cases students, by discussing already completed designs and asking the for the students' opinions of these. In this research, the direct communication methods were used mainly in phases three and five of the research. In phase three teachers discussed concerns about the design process of learning environments with an architect and this was a good example of how direct communication could help in gathering designers and users together to build mutual respect for the different skills they bring to a design process. In phase five the discussion sessions that gathered students, 
teachers, and the researcher together to finalise the classroom layouts seemed successful, as the users felt encouraged by participating in the design process of their learning environments. They also gained new knowledge by discussing architectural issues with the researcher. Users suggested ideas that were discussed with other users and the researcher was able to clarify the positives and negatives of each idea. Direct communication also saved time, as many ideas were discussed, rejected, or accepted in a short time, compared to generating ideas from the drawings of students. However, this method also relies on having an independent person with design skills to act as a facilitator. It may, however, take less time overall than analysing children's drawings. Perhaps more importantly, these two methods show that participatory design can happen in more than one way in New Zealand schools.

Social media is another method to consider for involving users in the design process of learning environments. Again, although studies overseas of doing this exist (see section 7.1.1) there is almost no evidence of its use in designing learning environments in New Zealand. This research included an experiment using social media to encourage teachers and students to collaborate in thinking about the design of their learning environments. Unfortunately, although one school provided very good evidence of how children can become engaged in thinking about design, the sample was too small to draw any clear conclusions. However, in phase four, social 
media, using an existing Google drive, was used as a forum for gathering staff ideas and thoughts about the school rebuilding project (see section 7.3.4.3). However, it still needed further development to represent proper participatory design. For example, the drive contained some comments and thoughts but there was no discussions of these or how to include them in the final designs. It seems that the drive was used to collect teachers' thinking without necessarily considering converting this to designs. Overall, however, social media seems to work better when used for a specific project although a good example of its use in New Zealand is still needed as an exemplar for others to follow.

The last method to be discussed here is the display project at Thorndon School (see section 7.3.4.6) which was used to involve students, teachers, and parents in the design of the ongoing rebuilding project. In the display, students and teachers as users could participate in commenting on the existing spaces and the new ideas that the school principal suggested. However, as discussed (see section 8.1.3) this is more like consultation as the method did not provide the opportunity for users to generate ideas. The main aim appeared to be to make the users comment on and recommend the ideas already posted on the display. Students had suggested some new ideas but they were few in comparison to the ideas on the display. Again, further development is needed make this a true participation method. 
For instance, year groups could have been given a specific day to post their ideas to help give the process focus.

The answer to the sub-question "What are the current methods used for participatory designs in learning environments?" is difficult. A number of methods are available but it seems these seldom lead to true participation when used in New Zealand, especially by children, so there is a need for more encouragement to use proper methods for participatory design in learning environments in $\mathrm{New}$ Zealand.

\subsubsection{The Ministry's ROle in IMPROVIng the Design PROCESS}

The Ministry of Education has the real power to facilitate participatory design because they set the budget for schools. They also have the power to give clear guidance on the school design process and who the parties in the process are. Currently, the design process behind learning environments is not clear. The different parties involved add to the confusion. For example, in the Thorndon School rebuilding project in phase four of the research, there was confusion over the stages in the design process. The principal was consulting teachers about design ideas while working with the architects on different stages. The principal and architects needed to communicate with members of the Ministry in addition to members of Board of Trustees while also trying to communicate with users and members of the community. The architect interviewed for phase one (see appendix C ) 
summarised this well, by saying the Ministry is the official client, but the school, including the principal, teachers, and students, are the users of the space. Thus they should be the real clients. The Ministry could simplify the process by reducing the number of people involved. This does not mean not involving students and teachers in the design process but rather creating a new process so that the architects work directly with the users when making the final decisions. The role of the Ministry in the design process is still important but it could be less dominant than currently.

Another issue in the design process is that the decision making is not done by one party, which can create conflict in the design. For example, the Ministry provides a budget for the architects to design learning environments, but this does not include the furniture for these, and the designs created by the architects may need certain types of furniture for optimal use. If all the decisions about the designs, including the furniture, fixtures, and other design elements, were made through the same process, the schools could work with more harmony and consistency.

The architects also claim that there is a lack of resources to help them in designing learning environments, which gives a negative answer to the sub-question "Do designers have enough resources to involve users in the design process?" The Ministry needs to offer more resources, especially in terms of exemplars, for architects about designing learning environments in general and specifically about involving 
users in the design process. In this way, the Ministry could encourage more participatory designs of learning environments. The Ministry has the biggest influence over the design process, as the final decisions need to be approved by them. In addition, it is easy for the Ministry to reach all schools and architects. Thus, all the suggested changes in the design process of learning environments could be controlled and managed by the Ministry.

\subsubsection{THE RESEARCH QUESTIONS}

Although the sub-research questions have been answered it is necessary to return to the main two part research question.

What lies behind the design process of the current layouts of New Zealand primary school classrooms? How, if necessary, could the design process be improved for better perceived learning outcomes?

From the discussion above it seems that although there is support for having a participatory design process for modern learning environments little thought has yet been given to how this might be achieved in New Zealand primary schools. The current design process, therefore, is one that maintains the status quo without the true user participation. It also seems that although there are ways to change this process to a true participatory one this will require rethinking how the process might work and how any additional costs are to be supported. What is clear from the research is that achieving this would lead to better learning outcomes. 
Ultimately the issue seems to be one of who has power over the design process. At the moment the powerful players are the ministry, the school principal and the architect. Children are at the bottom of the list when it comes to having power over the environments in which they work and learn. Perhaps participatory design is really about the empowerment of children.

\subsubsection{Limitations OF THE STUDY}

As with any research, this thesis has its limitations because of the resources and time frame available for the study of this complex subject. It was not even possible to carry through the case study of participatory design at Thorndon School because this was going to occur over many years. This research, therefore, is a snapshot of the current design process. The research of necessity has also only focused on one aspect of the design process behind learning environments in New Zealand, that of the involvement of users in the design process.

\subsubsection{FURTHER RESEARCH}

One aspect of the research that could be completed is a followup study of the Ministry of Education's pilot project for learning studios. Further studies could include investigation of how these were used over a number of years and the effect they had on learning outcomes. The investigation could also include the feedback of the users of these environments. This research could be enriched if detailed comparison could be 
made between the use of learning studios and normal single cell classrooms in the same school.

The limited time frame meant that further consultation with the Ministry, beyond obtaining their permission for the study at the start, was not possible. This is an area for follow-up research. Presenting the results to the Ministry either before or after interviewing the relevant parties would have extended the results, since many conclusions lead back to the Ministry making changes when it comes to the design process. In some sections in this thesis, especially phase three (see section 7.2), participants suggested the Ministry should provide better guidelines for designing learning environments, especially when it comes to involving the users in these. Further studies could cover the Ministry's future actions based on the results of the different phases of this study. It would also be essential to have a longitudinal study of participatory design in action. This might include more detailed study of the use of social media as a tool in this.

The Ministry could improve their guidelines for architects and schools to support and encourage more participatory design in learning environments. The guidelines could suggest easy methods or ways to support participatory design. As a start they could summarise international studies where children had participated in the design of their schools and classrooms, and supplement these with examples from New Zealand as these become available. The Ministry could also provide a link in their website to successful examples of 
participatory designs overseas. Another suggestion for the Ministry of Education is that they consider conducting a conference or even small workshops where teachers and school staff can gather and talk with architects and design professionals. There could be also a section in the Ministry website that summarises all the discussions and results of these meetings, making these available for all schools in New Zealand. The suggestions to the Ministry of Education could be a subject area for future studies to test these and find out whether improving the Ministry guidelines improves communication between the different parties in the design process.

Other areas for further studies include aspects mentioned briefly in the thesis that are outside its scope, such as investigating micro-worlds and interactive designs in learning environments, environmental psychology and the relationship between the built environment and the behaviour of the users, and the effect of the biophilia (love of nature) hypothesis on the design of learning environments.

\subsection{CONCLUSiOnS SUMMARY}

The key conclusions of this thesis are that all parties involved in this research supported user participation in the design process, but in all the cases investigated there was almost no proper participatory design. It was also apparent that when they were offered the opportunity students enjoy designing their learning environments and that enjoyment made them have a positive attitude towards these. Additionally, they 
were capable of understanding architectural drawings and, with guidance, coping with the problem of scale. Overall, students showed good general knowledge about designing learning environments in relation to their ages. The most important result is that students could work along with architects, as they understand many elements involved in the design of learning environments. However, there is a clear need for proper guidelines to direct schools and architects on the involvement of young students in the design process of learning environments. 


\section{BIBLIOGRAPHY}

Alsaif, F. (2011). Intelligence-friendly environments: A study of New Zealand primary school classroom design in relation to multiple intelligences theory. A master's thesis in Victoria University of Wellington.

Armstrong, T. (2009). Multiple intelligences in the classroom. Alexandria, VA, USA: ASCD.

Arnold, A. C., Britton-Simmons, M., Williams, R., Brewbaker, J., Ranson, S. R., Tomasik, B., \& Proctor, K. (1993). The Round Table: Designing Classrooms with Students in Mind. English Journal, 81-83.

Babbage Architects and Ministry of Education. (2012). Learning studio design guide. (Provided privately by the Ministry of Education)

Babbage Consultants Limited. (2012). Remarkables Primary School. Retrieved Jun 19, 2012, from http://www.babbage.co.nz/projects/remarkablesprimary-school

Baker, L. (2012). A history of school design and its indoor environmental standards, 1900 to today. National Clearinghouse for Educational Facilities. Retrieved October 14, 2014 from: http://eric.ed.gov/?id=ED539480

Barrie, C. W. (2012). The Emergence of Collective Dreams: An Exploration of Community Development Based Collaborative Landscape Design. A Master's Thesis in Design, Victoria University of Wellington. 
Baum, S. Viens, J. Slatina, B. (2005). Multiple intelligences in elementary classrooms. New York, NY: Teachers College Press.

Bentley, J. H., \& Ziegler, H. F. (2011). Traditions \& encounters: a global perspective on the past. New York: McGraw-Hill.

Bevin and Slessor Architects. (2012). Seatoun School. Retrieved Jun 19, 2012, from http://www.bevinslessor.co.nz/projects/seatounschool. $\underline{\mathrm{htm}}$

Bill, D. (2014, August). 8 Tips and Tricks to Redesign Your Classroom. Retrieved October 3, 2014 from: http://www.edutopia.org/blog/8-tips-and-tricksredesign-your-classroom

Blake, P., \& Busby, S. (1994). Noise levels in New Zealand junior classrooms: Their impact on hearing and teaching. The New Zealand Medical Journal,107 (985), 357-358.

Bland, D. C. (2009). Re-imagining school through young people's drawings. In Conference Proceedings of the 1st International Visual Methods Conference University of Leeds, Leeds, England. 15th-17th September 2009

Bland, D. C. (2011). Drawing on imagination: Primary students' ideal learning environments. In AARE 2010 conference proceedings. November 28 - December 2 , 2010, Melbourne, Australia.

Boucher, K. (2011). Not Just Little Boxes. Teacher: The National Education Magazine, May, 2011, 36-38, 4041. 
Brandt, E. (2006, August). Designing exploratory design games: A framework for participation in participatory design? In Proceedings of the ninth conference on Participatory design: Expanding boundaries in designVolume 1 (pp. 57-66). August 1-5, 2006. Trento, Italy.

Briethecker, D. (2003). Federal Working Group of Posture and Movement, Wiesbaden, Germany. Australia School Library Association Conference, Hobart, Tasmania, October 2003.

Burke, C. (2007). The view of the child: Releasing "visual voices" in the design of learning environments. Discourse: studies in the cultural politics of education, 28(3), 359-372.

Cassidy, T. (2013). Environmental psychology: Behaviour and experience in context. New York, Psychology Press.

Chalet, A. M., \& Guttmann, M. (2008). School buildings and architecture. Retrieved October 14, 2014 from http://www.fags.org/childhood/Re-So/SchoolBuildings-and-Architecture.html

Chapman Oulsnam Speirs. (2012a). Kaponga Library. Retrieved Jun 19, 2012. from http://www.cosl.co.nz/projects.asp?id=50

Chapman Oulsnam Speirs. (2012b). Opunake Te Putahi Ako. Retrieved 19 Jun 2012, from http://www.cosl.co.nz/projects.asp?id=115

Clark, R. H. and Pause. M. (2012) Precedents in Architecture: Analaytic Diagrams, Formative Ideas and Partis, New Jersey: John Wiley and Sons Inc. 
Classroom architect. (2008). Retrieved October 3, 2014 from: http://classroom.4teachers.org/index.html

Demirbilek, O., \& Demirkan, H. (2004). Universal product design involving elderly users: A participatory design model. Applied Ergonomics, 35(4), 361-370.

Department of Health and Human Services (2008). Focus groups. Evaluation Briefs, no. 13. Retrieved September 10, 2014, from http://www.cdc.gov/healthyyouth/evaluation/pdf/brief1 $\underline{3 . p d f}$

Dewey, J. (1899). The School and Society, Chicago: The University of Chicago Press.

De Winter, M., Baerveldt, C., \& Kooistra, J. (1999). Enabling children: Participation as a new perspective on childhealth promotion. Child: care, health and development, 25(1), 15-23.

DLA Architects, Hamilton. (2012). Te Totara Primary School. Retrieved Jun 19, 2012, from http://www.dla.co.nz/index.php?page=projects\&do=vi ewproject\&id $=64$

Donnachie, I (2000). Robert Owen: Owen of New Lanark and New Harmony, East Linton: Tuckwell Press Ltd

Dorrell, A. (2000). Tips for furnishing the learning environment. Retrieved March 16, 2012, from U.S. Department of Education, Educational Resources Information Center (ERIC):

http://eric.ed.gov/ERICWebPortal/search/detailmini.js p? nfpb=true\& \&ERICExtSearch SearchValue $0=E$ D455668\&ERICExtSearch SearchType 0=no\&accno $=\underline{E D 455668}$ 
Dovey, K., \& LeGrew, D. (1979). The Child's Place: Drawings and Visions. Architecture Australia, 68(June/July 1979), 37-42.

Driscoll, A. \& Nagel, N.G. (2012). Reggio Emilia Approach. Retrieved November 14, 2014 from Education.com: http://www.education.com/reference/article/reggioemilia-approach/

Evans, D., \& Gruba, P. (2007). How to write a better thesis. Victoria, Australia: Melbourne University Press.

Featherston, M. (2006). Designing from the 'Inside-out'. Retrieved February 7, 2012, from: http://www.featherston.com.au/1668/designing-fromthe-\%E2\%80\%98inside-out

Featherston, M. (2010). Creating Creative Spaces. Retrieved February $7, \quad 2012, \quad$ from http://www.featherston.com.au/508/508

Fielding Nair International (2014). Fielding Nair International: architects and change agents for education. Retrieved November 20, 2014 from: http://www.fieldingnair.com/

Fink, A. (Ed.). (2003). The survey handbook (Vol. 1). New York: Sage.

Francis, M., \& Lorenzo, R. (2002). Seven realms of children's participation. Journal of environmental psychology, 22(1), 157-169.

Gorst, J. (1906). The Children of the Nation, London: Methuen.

Groat, L., \& Wang, D. (2002). Architectural research methods. New York: John Wiley \&Sons, Inc. 
Hadjri, K., \& Crozier, C. (2009). Post-occupancy evaluation: purpose, benefits and barriers. Facilities, 27(1/2), 2133.

Hadow, W. (1931). The Primary School. Report of the Consultative Committee London: HMSO - Retrieved November $12, \quad 2014$ from: http://www.educationengland.org.uk/documents/hado w1931/hadow1931.html

Hassell, K. (2011). Flexible classroom furniture. American School \& University, 84(2), 18-21.

Hagen, P., \& Robertson, T. (2010). Social technologies: challenges and opportunities for participation. In Proceedings of the 11th Biennial Participatory Design Conference. New York. November 29 December 03, 2010 (pp. 31-40). ACM.

Iltus, S., \& Hart, R. (1994). Participatory planning and design of recreational spaces with children. Architecture \& Comportement/Architecture \& Behaviour. 10 (4), 361370.

Johnson, M. (2013). How social media changes user-centred design: Cumulative and strategic user involvement with respect to developer-user social distance. Aalto University publication series. Retrieved September 17, 2014 from: http://inuse.fi/2013/03/15/johnson-2013how-social-media-changes-user-centred-design/

Kaasinen, E., Koskela-Huotari, K., Ikonen, V., \& Niemeléi, M. (2013). Three approaches to co-creating services with users. Advances in the Human Side of Service Engineering, edited by James C. Spohrer, Louis E. Freund, p 286-295. 
Kane, P. J., Pilcher, M., \& Legg, S. J. (2006). Development of a furniture system to match student needs in New Zealand schools. In 16th World Congress on Ergonomics (July 10-14, 2006) Maastricht, the Netherlands.

Kitzinger, J. (1994). The methodology of focus groups: The importance of interaction between research participants. Sociology of Health \& IIIness, 16(1), 103121.

Knight, G., \& Noyes, J. (1999). Children's behaviour and the design of school furniture. Ergonomics, 42(5), 747760.

Lackney, J. (1999). A history of the studio-based learning model. Retrieved March 8, 2012. from http://www.edi.msstate.edu/work/pdf/history studio b ased learning.pdf

Laiqa, R. U. A., Shah, R. U., \& Khan, S. M. (2011). Impact of quality space on students academic achievement. International Journal of Academic Research, 3(3), pages 706-711.

Leaman, A. \& Bunn, R. (2014). School buildings. School design together, P138-152. Pamela Woolner (Ed). New York:Routledge,

Legg, S. (2007). Ergonomics in schools: In memoriam-Cheryl Bennett. Ergonomics, 50(10), pages 1523-1529

Liamputtong, P. (2011). Focus group methodology: Principle and practice. London, Sage Publications. 
Li, Y. L. (2006). Classroom organization: Understanding the context in which children are expected to learn. Early Childhood Education Journal, 34(1), 37-43.

Lillard, A., \& Else-Quest, N. (2006). Evaluating Montessori education. Science, 311(5795), 1893.

Lloyd, J. (2013). York County grew up in one room school houses [Photograph]. Retrieved October 21, 2014 , from http://www.ydr.com/ci 23267191/june-lloyd-yorkcounty-grew-up-one-room

Loader, D. (2010). Chairless in Charleville. Teacher: The National Education Magazine, (April 2010), 71.

Luck, R. (2003). Dialogue in participatory design. Design Studies, 24(6), 523-535.

Mackay, C. (2003). Sunshade design in New Zealand primary schools. In $20^{\text {th }}$ PLEA November, 2003 ConferenceProceedings, Santiago de Chile. (pp. 143-148).

Mannion, G. (2007). Going spatial, going relational: Why "listening to children" and children's participation needs reframing. Discourse: studies in the cultural politics of education, 28(3), 405-420.

Mclntosh, J. (2011). The indoor air quality in 35 Wellington primary schools during the day. A Master's thesis, Victoria University of Wellington.

Meshchaninov, Y. (2012). The Prussian-Industrial History of Public Schooling. The New American Academy. Retrieved November 12, 2014 from: http://www.thenewamericanacademy.org/images/theprussian-industrial-history-of-public-schooling1.pdf 
Merrell, R. G. (1968). Guidelines for designing, equipping and furnishing small school learning laboratories. Retrieved March 16, 2012 from Educational Resources Information Center(ERIC): http://eric.ed.gov/ERICWebPortal/search/detailmini.js p? nfpb=true\& \&ERICExtSearch SearchValue $0=E$ D027100\&ERICExtSearch SearchType 0=no\&accno $=\underline{E D 027100}$

Ministry of Social Development (2003) Involving Children. Retrieved from Ministry of Social Development March 26, 2014 : http://www.msd.govt.nz/documents/aboutmsd-and-our-work/publicationsresources/archive/2003-involving-children.pdf

Ministry of Education (1957) The story of post-war school building, London: HMSO

Ministry of Education. (2007). Designing quality learning spaces. Building Research Association of New Zealand (BRANZ Ltd). Retrieved March 1, 2012, from Ministry of Education website: http://www.minedu.govt.nz/NZEducation/EducationPol icies/Schools/SchoolOperations/PropertyManagement IStateSchools/PerformingClassrooms/DesigningQualit yLearningSpaces.aspx

Ministry of Education. (2012a). Learning studio pilot review. Schools Infrastructure Group. (Provided privately by the Ministry of Education)

Ministry of Education. (2012b). Modern learning environment examples. Retrieved from the Ministry of Education website July 10, 2014: http://www.minedu.govt.nz/NZEducation/EducationPol 
icies/Schools/PropertyToolBox/StateSchools/Design/ ModernLearningEnvironment/MLEEgs.aspx

Ministry of Education. (2014a). Auckland Normal Intermediate. Retrieved September 19, 2014 :

http://www.mle.education.govt.nz/assets/Uploads/ML E/Case-

Studies/AucklandNormallntermediateCasestudyJuly2014.pdf

Ministry of Education. (2014b). Breens Intermediate. Retrieved September 19, 2014 from: http://www.mle.education.govt.nz/assets/Uploads/ML E/Case-

Studies/BreensIntermediateMLECasestudyJune2014. $\underline{\mathrm{pdf}}$

Ministry of Education. (2014c). Modern Learning Environments. Retrieved September 18, 2014 from: http://www.mle.education.govt.nz/

Ministry of Education. (2014d). Woolston School. Retrieved September 19, 2014 from:

http://www.mle.education.govt.nz/assets/Uploads/ML E/Case-Studies/WoolstonSchoolMLECaseStudyJune2014.pdf

Montessori, M. (1912) (trans. George A. E.) The Montessori Method, New York: Frederick A. Stokes Co.

Morrow, L. M. (1990). Preparing the classroom environment to promote literacy during play. Early Childhood Research Quarterly, 5(4), 537-554.

Nair, P., \& Fielding, R. (2007). The language of school design: Design patterns for 21st century schools. Minneapolis: Design Share. 
Näkki, P., \& Antikainen, M. (2008). Online tools for co-design: User involvement through the innovation process. New Approaches to Requirements Elicitation, (96), 92-97.

Nesset, V., \& Large, A. (2004). Children in the information technology design process: A review of theories and their applications. Library \& Information Science Research, 26(2), 140-161.

New Zealand Institute of Architects Incorporated. (2012). New Zealand Architecture Awards. Retrieved July 10, 2012 from: $\quad$ http://www.nzia.co.nz/awards/new-zealandarchitecture-awards/nz-architectureawards.aspx?activeYear $=2012$

Oxley, D. (2004). Small learning communities - small schools coalition. Retrieved October 15, 2014 from http://smallschoolscoalition.com/wpcontent/uploads/2012/01/Laboratory-for-StudentSuccess-Small-Learning-Communities.pdf

Pankhurst, H. (1922) Education on the Dalton Plan, New York: E. F. Dutton and Co.

Parnell, R. (2014). Co-creative adventures in school design. School design together, p123-137. Pamela Woolner (Ed). New York:Routledge

Preiser, W. F. (1995). Post-occupancy evaluation: how to make buildings work better. Facilities, 13(11), 19-28.

Resene Total Colour Award. (2012). Flanshaw Road Primary School. New Junior block. Retrieved June 19, 2012, from

http://www.resene.co.nz/colourawards/Flanshaw.htm 
Reyes, L. F. M. (2012). Participatory design through social media: The translation of a future workshop. Retrieved September 11, 2014 from: https:/www.duo.uio.no/bitstream/handle/10852/9070/r eyes.pdf? sequence $=2$

Reyes, L. F. M., \& Finken, S. (2012, August). Social media as a platform for participatory design. In Proceedings of the 12th Participatory Design Conference: Exploratory Papers, Workshop Descriptions, Industry CasesVolume 2. Roskilde, Denmark, in August 2012. (pp. 8992). ACM.

Rieber, L. P. (1996). Seriously considering play: Designing interactive learning environments based on the blending of microworlds, simulations, and games. Educational technology research and development, 44(2), 43-58.

Saarni, L., Nygård, C. H., Kaukiainen, A., \& Rimpelä, A. (2007). Are the desks and chairs at school appropriate? Ergonomics, 50(10), 1561-1570.

Sachsse, M. (2003). But will it work for a "brownfield" site? Tea Tree Gully three years on [Photograph]. Retrieved October 21, 2014, from http://www.ascilite.org.au/asetarchives/confs/edtech94/rw/sachsse.html

Said, I. (2007). Architecture for Children: Understanding Children [sic] Perception towards Built Environment. In: Proceedings of International Conference Challenges and Experiences in Developing Architectural education in Asia, Islamic University of Indonesia, 8-10 June, 2007. (Unpublished) Retrieved March 1, 2012, from http://eprints.utm.my/3575/ 
Sanders, E. B. N., Brandt, E., \& Binder, T. (2010). A framework for organizing the tools and techniques of participatory design. In Proceedings of the 11th biennial participatory design conference (pp. 195-198). November 29 - December 3, 2010. Sydney, Australia.

Sanoff, H. (2011). Multiple Views of Participatory Design. Focus: Journal of the City and Regional Planning Department, 8(1), 7.

Scaife, M., Rogers, Y., Aldrich, F., \& Davies, M. (1997). Designing for or designing with? Informant design for interactive learning environments. In Proceedings of the ACM SIGCHI Conference on Human factors in computing systems (pp. 343-350). March 22-27, 1997. Atlanta, Georgia.

Seaborne, M. (1971). Primary school design. London: Routledge \& Kegan Paul.

Seaborne, M., \& Lowe, R. (1977). The English School. London: Routledge \& Kegan Paul.

Seldin, T. (2001). Designing facilities for Montessori schools: Montessori classroom design. The Montessori Foundation Press. Retrieved October 16, 2014 from http://www.montessori.org/sitefiles/designing facilities .pdf

Sheerin, B. (2008). New Zealand: Modernizing schools in a decentralized environment. OECD Publications PEB Exchange, 2 (1609-7548). Paris, France.

Sheerin, B., \& Bruce, P. (2004). Best practice in school design: Ministry of Education. Wellington:NCNielsen 
Shield, B., Greenland, E., \& Dockrell, J. (2010). Noise in open plan classrooms in primary schools: A review. Noise and Health, 12(49), 225.

Simaika, J. P., \& Samways, M. J. (2010). Biophilia as a universal ethic for conserving biodiversity. Conservation Biology, 24(3), 903-906

Stanford, P. (2003). Multiple intelligence for every classroom. Intervention in school and clinic, 39(2), 8085.

Steadman, P. (2014). Building Types and Built Forms. Leicester: Troubador Publishing Ltd.

Thomson, P. (2008). Doing visual research with children and young people. London: Routledge.

Thorndon School. (2014). Retrieved from Thorndon school website May 15, 2014: http://www.thorndon.school.nz/

Tocci, C., Hochman, D., \& Allen, D. (2005). Advisory programs in high school restructuring. Paper presented at the annual meeting of the American Education Research Association. April 11-15, 2005. Montréal, Canada.

West, H. (2007). Spaces for Learning: Designing Classroom Space. Teacher: The National Education Magazine, (July 2007), 8.

Whitlock, J. Dodd, G. (2004). Classroom acoustics: Milestone 6 report. Auckland Uni-Services Limited. Retrieved October 23, 2014, from: http://www.minedu.govt.nz/ /media/MinEdu/Files/Edu cationSectors/P 
rimarySecondary/PropertyToolbox/StateSchools/Desi gn/Acoustics/Cla ssroomAcoustics.doc

Yin, R. K. (1994). Case study research: Design and methods. London, Sage Publications.

Zhang, Y., \& Barrett, P. (2010). Findings from a postoccupancy evaluation in the UK primary schools sector. Facilities, 28(13/14), 641-656.

Zimmerman, A., \& Martin, M. (2001). Post-occupancy evaluation: benefits and barriers. Building Research \& Information, 29(2), 168-174.

Zimring, C. M., \& Reizenstein, J. E. (1980). Post-occupancy evaluation an overview. Environment and Behavior, 12(4), 429-450. 


\title{
APPENDICES
}

Lists of New Zealand schools and architectural firms are

provided in the $\mathrm{CD}$ attached to the thesis.

\author{
APPENDix A: THE ETHICS APPROVAl FOR THIS \\ PHD RESEARCH
}

TE WHARE WÃNANGA O TE OPOKO O TE IKA A MÃUI

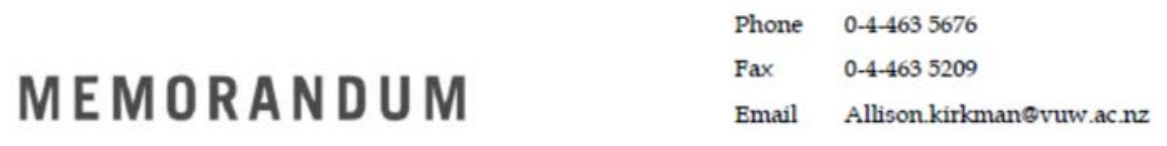

\begin{tabular}{l|l}
\hline TO & Fatimah Alsaif \\
\hline COPY TO & $\begin{array}{l}\text { Brenda Vale } \\
\text { Christina Mackay }\end{array}$ \\
\hline FROM & Dr Allison Kirkman, Convener, Human Ethics Committee \\
\hline DATE & 6 December 2012 \\
\hline PAGES & 1 \\
\hline \multicolumn{2}{|l}{} \\
\hline SUBJECT & $\begin{array}{l}\text { Ethics Approval: } 19583 \\
\text { Primary classroom interiors: the role of design }\end{array}$ \\
\hline
\end{tabular}

Thank you for your application for ethical approval, which has now been considered by the Standing Committee of the Human Ethics Committee.

Your application has been approved from the above date and this approval continues until 28 February 2015. If your data collection is not completed by this date you should apply to the Human Ethics Committee for an extension to this approval.

Best wishes with the research.

Allison Kirkman

Human Ethics Committee 
APPENDIX B: TEACHERS PHASE ONE FOCUS GROUP

Session Notes:

Teacher 1: from new school (opened last year) (she has experience in old schools)

Teacher 2: from old schools (built in 1960s or 1970s)

\section{Classroom layout}

Teacher 2: You are limited with the furniture you have got, and the number of students. I have 29 students and had to squeeze in enough chairs and tables for this number of students. Last year I had 20. The type of furniture is tables and chairs.

Teacher1: We don't have many tables and chairs. We have two learning suites that connect to each other and are open. There are 72 students in there. There are three tables enough to set 15 students on tables. In addition, there are beanbags and ottomans. The architects should design learning environments to be more like learning studios than single cell classrooms. They need to talk with people and make note of the direction of education.

Teacher 2: Designing new schools or upgrading old ones, is actually thinking of changing the space. The classrooms from the 1970s are still the same in size.

Involvement in design process: 
Teacher 2: One of the schools I have worked in was a school that had a new admin block and staff room, but the design didn't come from the staff. It was generated by the principal. The principal had consulted the staff but in the end the consultant did not change anything in the design. Nobody asks about what would be practical in a classroom, what would you really like or where you would put the sink. Do you need a wet area or not? I have never been asked that.

Teacher 1: Not for the current school. In my previous school with single cell classrooms built in the 1900s, the walls between classrooms were removed to have bigger spaces. Teachers were consulted about this. However, not much change happened. They became bigger classrooms with two teachers.

\section{Choosing furniture:}

Teacher 2: We deal with the furniture around us. It would give us freedom if we got the money to buy new stuff. But with existing furniture if it is are working you have to deal with what you have got.

Teacher 2: When you learn to be a teacher that is what you see in classrooms. This might be why teachers stick with what they have seen and tried. You need a flat surface for children to write on for example. All of the schools seem to have shades of the same colour. Maybe they were designed to be a plain canvas. I change the class layout every term, but the children 
are doing the same things. We still have a mat area, chairs and tables.

\section{Classroom size:}

Teacher 2: We have enough space for classroom activities, and we are lucky to have the school hall for music and drama.

Teacher 1: When I was teaching in single cell classrooms the classrooms were not big enough for all the activities. Because everyone wants to set the same things in their classrooms, there were a maths area, music area, drama, but when we opened the classrooms to each other, three classrooms had one library area. So we have got a massive area for other activities. In the old school the corridors were taking massive areas. No one can use the space there. In the new school the corridors are inside the classrooms so the area is well used.

\section{Different activity corners inside classrooms:}

Teacher 2: It is ideal to have an art room, but we do art inside the classroom.

\section{Discussing the furniture layout with students:}

Teacher 1: We talk a lot, especially because they come from different classroom layouts, and they need to understand the new layout. We were asking children to help us complete furnishing the areas but students kept saying no more tables. They gave us other ideas to work with like having small chairs or ottomans to write on, or to have a hard surface on their laps like a tote tray. Some of them like to lie down. So they have 
the option to work on tables or the floor. We don't often all work at the same time but if we have to write at the same time students go anywhere. In terms of the noise, there is no noise as the space is not a big rectangular space. The space has hooks and separated rooms opening to the central space. We have 4 teachers. They don't mind not having their own spaces or tables. There are a lot of things going on online so they don't need to carry a lot of staff. They have their tote trays and space for their bags.

\section{Technology:}

Teacher 1: Desktops, laptops, tablets, e-readers.

Teacher 2: They don't have enough power points. If they have laptops they can't all charge them at the same time. The layout of the classroom may be affected by the placing of the plugs.

\section{Last renovation:}

Teacher 2: The classrooms are the same. The office and staff room have been upgraded. Teachers don't talk about their needs to the board of trustees. I did not visit new schools. We can get rid of furniture, but you might need it the year after. There is no window treatment for the sun glare

Teachers did not know about the guidelines provided by the Ministry of Education.

\section{Learning to be a teacher:}


Teacher 2: Many teachers and schools haven't seen what it looks like to teach in different styles.

Teacher 1: When I talked with some teachers about the open plan learning environments they said that these environments did not work in the 1970s. We need small closed rooms within the learning suites to provide some privacy and quiet space.

Teacher 2: They teach us to be old fashion teachers teaching in single cell classrooms.

Teacher 1: Teaching in this new school has changed in my teaching style. 


\section{APpendix C: Phase ONE ARCHITECTS FOCUS GROUP}

Only one architect attended. These are the notes from the session.

Architect: There are two reasons for the lack of studies and examples of user participation in New Zealand. The principals often make the decisions about what teachers and students need. They play the role of "gate keeper" while they may not have been in a classroom for many years. The classrooms in New Zealand are very old and not really appropriate to meet with the demands of overseas studies. Teachers are used to putting up with what they are given. They do not recognize what a good classroom design can add to learning.

The architect mentioned that one principal said to him: "I have never realized what a difference that a good classroom environment could make to education until this project" (a new project involving designing classrooms)

Architect: the New Zealand curriculum does not say anything about the environment of learning, yet other curricula around the world discuss this environment. Many principals, especially Wellington principals, have no experience of quality learning environments. The board of trustees also has little or no knowledge about learning environments. Project managers try to accomplish projects with low costs and not with high quality designs. 
The main contact in school projects is with the principal. Teachers are not aware of the current overseas studies.

\section{Ministry of Education}

Architect: The Ministry standards are not supported with good knowledge. Architects in Wellington do not have people in Ministry to approach. In Auckland, the Ministry has a good resource for teaching environments. That would help architects in other parts in New Zealand.

The School division of the Ministry is based in Auckland, which makes it easier to design schools in Auckland. The website only has some examples.

\section{Design process:}

Architect: Most architects follow the traditional design process. However, the question could be what would you modify in the traditional process? There is no specific person to discuss the new ideas with. This study opened my mind to ideas I did not think about before. In terms of post occupancy evaluations, formally architects are not paid to do these, but for most projects they go back and ask about the design and apply what they learn as feedback in other projects. Architects have no control over the furniture choices because of the separate budget for this. They tell the school they are happy to help in choosing furniture, and sometimes they do, and sometimes not. Architects design the classroom according to the number of students in the brief.

\section{Designing new schools}


Architect: Sometimes we conduct focus groups with principals to generate preliminary ideas. 


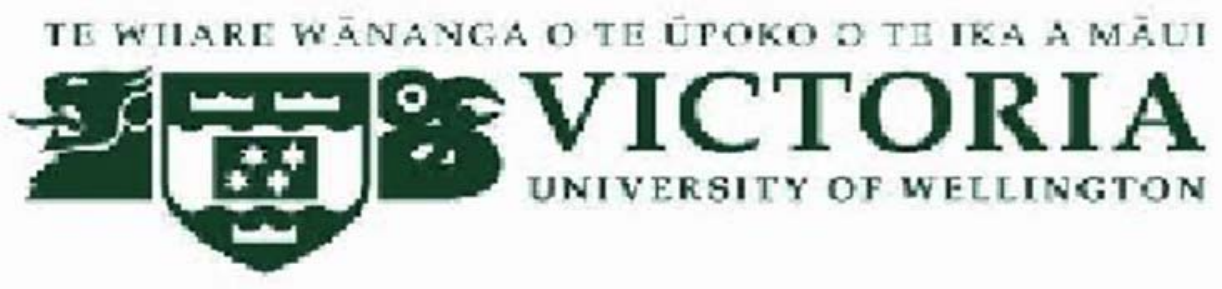

Information Letter for Teachers' Questionnaire

My name is Fatimah Alsaif and I am a PhD candidate at School of Architecture, Victoria University of Wellington. The main objective of my research is to investigate the internal layouts in New Zealand primary school year 5/6 classrooms. This includes finding out whether the current layouts are sufficient or not, if there are problems in the furniture arrangements, and the reasons for these problems. This information is about a self-administrated on-line questionnaire.

The questionnaire has been created based on the results of a focus group conducted with primary school teachers to explore the issues. The main objective of the questionnaire is to collect information about the existing layouts of primary school classrooms, and it should take about 15 minutes to complete. The questions are in three sections; the first section includes questions about your experience(s) in the classroom design process. The second section is about current classroom layouts and use of furniture. The third section asks about ideal layouts and design 
process. The expectation is the questionnaires are returned to the researcher within two weeks.

Should any participant feel the need to withdraw from the project, they may do so without question at any time before the data is analyzed. You may also withdraw up to two weeks after I receive your response. Responses collected will form the basis of my research project and will be put into a written report on an anonymous basis. It will not be possible for you to be identified personally. All material collected will be kept confidential. No other person besides my supervisors, Professor Brenda Vale and Christina Mackay, and myself will see the questionnaires. A summary of the data analysis will be provided at your request, after the project is completed (2015). The final thesis will be deposited in the University Library. It is intended that one or more articles will be submitted for publication in scholarly journals. Questionnaires will be destroyed five years after the end of the project.

If you have any questions or would like to receive further information about the project, please contact me at alsaiffati@myvuw.ac.nz or my supervisors, Professor Brenda Vale (brenda.vale@vuw.ac.nz) and Christina Mackay (christina.mackay@vuw.ac.nz), at the School of Architecture at Victoria University.

Thank you for your time,

Fatimah Alsaif 


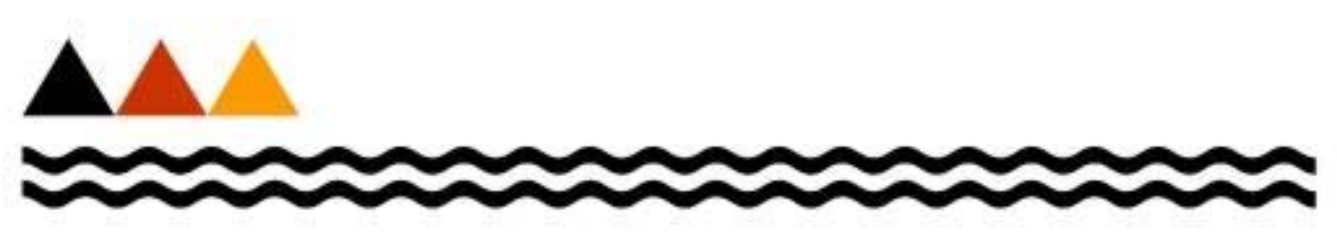

\section{I N I S T R Y O F E DUCATION}

\section{Te Tāhuhu o te Mātauranga}

The Ministry of Education supports this study and encourages you to complete this survey

\section{Consent Form for Teachers Questionnaire}

Please read through the following and sign at the end if you agree to take part in my research.

- I have been provided with adequate information relating to the nature and objectives of this research project, and have been given the opportunity to seek further clarification or explanations.

- I understand that I may withdraw from this study at any time before the final analysis of data without providing reasons.

- I understand that if I withdraw from the project, any data I have provided will be destroyed.

- I understand that any information I provide will be kept confidential to the researcher, and her supervisors, the published results will not use my name, and that no opinions will be attributed to me in any way that will identify me. I 
understand that the on-line questionnaire will be electronically wiped five years from the end of the project

- I understand that the information I have provided will only be used only for this research project in the ways described and that any further use will require my written consent.

According to the information provided, I agree to participate in this survey.

O Yes

O No

If No Is Selected, Then Skip To End of Survey

I would like to receive a summary of the results of this

research when it is completed.

O Yes

O No

Please provide your e-mail address.

Thank you for choosing to participate in our survey. We value your opinion and honest feedback. The survey will take approximately 15 minutes and will be completely anonymous. 


\section{General Questions}

Q1- When did the school you currently teach in open?

O Before 1990 (before Tomorrow's School Act)

O After 1990 (after Tomorrow's School Act)

Q2- In what type of school are you currently teaching?

O State school

O Integrated school

O Private school

Q3- In what type of learning space are you teaching?

O Single-cell classroom

O Open-plan environment

O Learning studio

O Prefabricated classroom

O Other

Q4- When was the last renovation of this learning space undertaken?

O Not ever renovated to my knowledge

O More than 20 years ago

O 20-10 years ago

O Less than 10 years ago

Comments:

Q5- How many students are currently in your learning area?

O Fewer than 20 students

O 20- 30 students

O More than 30 students 
Q6- How many full time teaching equivalents (FTE) teach in your learning area (please give a daily average)?

O Only me

O Up to 1 FTE besides me

O 1-2 FTEs besides me

O 2-3 FTEs besides me

O More than 3 FTEs besides me

O Other

Q7- The learning space I am teaching in is for...

O only year $5 / 6$

O year 3-6

O Other

\section{Participating in the Design Process}

Q8- Have you worked in a school that has been renovated while you were there?

O Yes

O No

If No Is Selected, Then Skip To Q 13 
Q9- Please agree or disagree with the following statements about designing schools. 


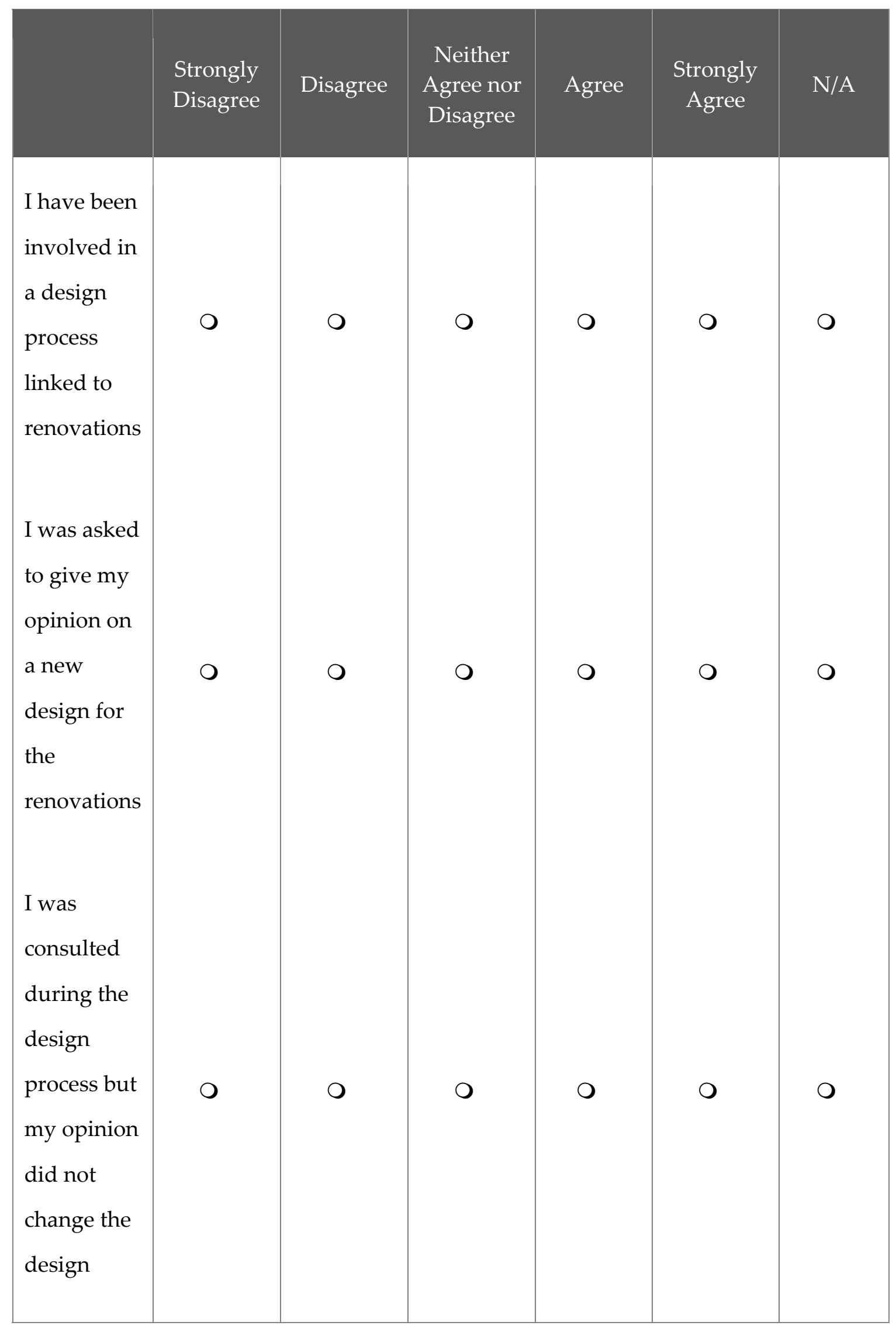




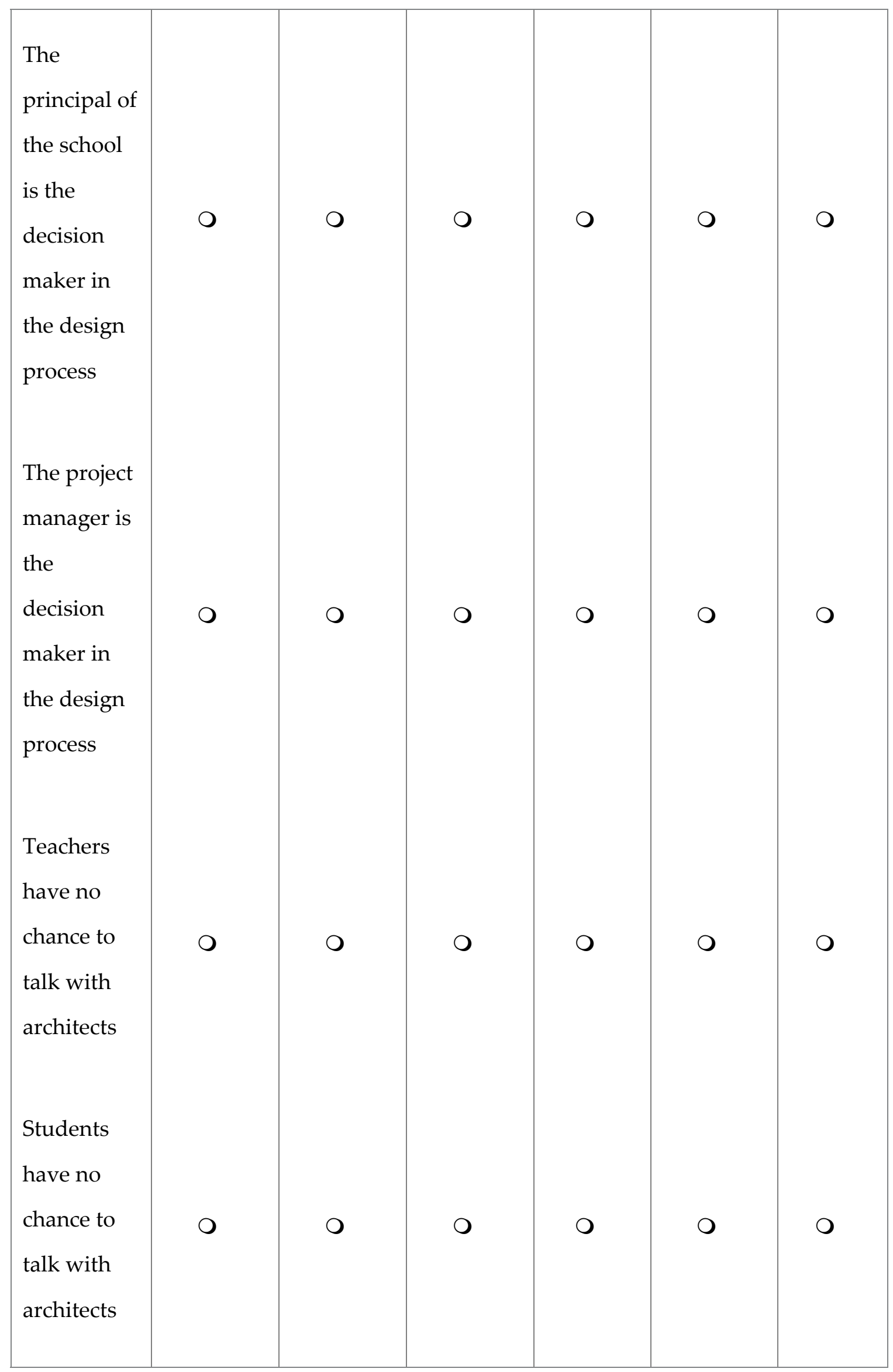


Q10- Please click as many boxes below as apply to the last primary school classroom project in which you participated. 


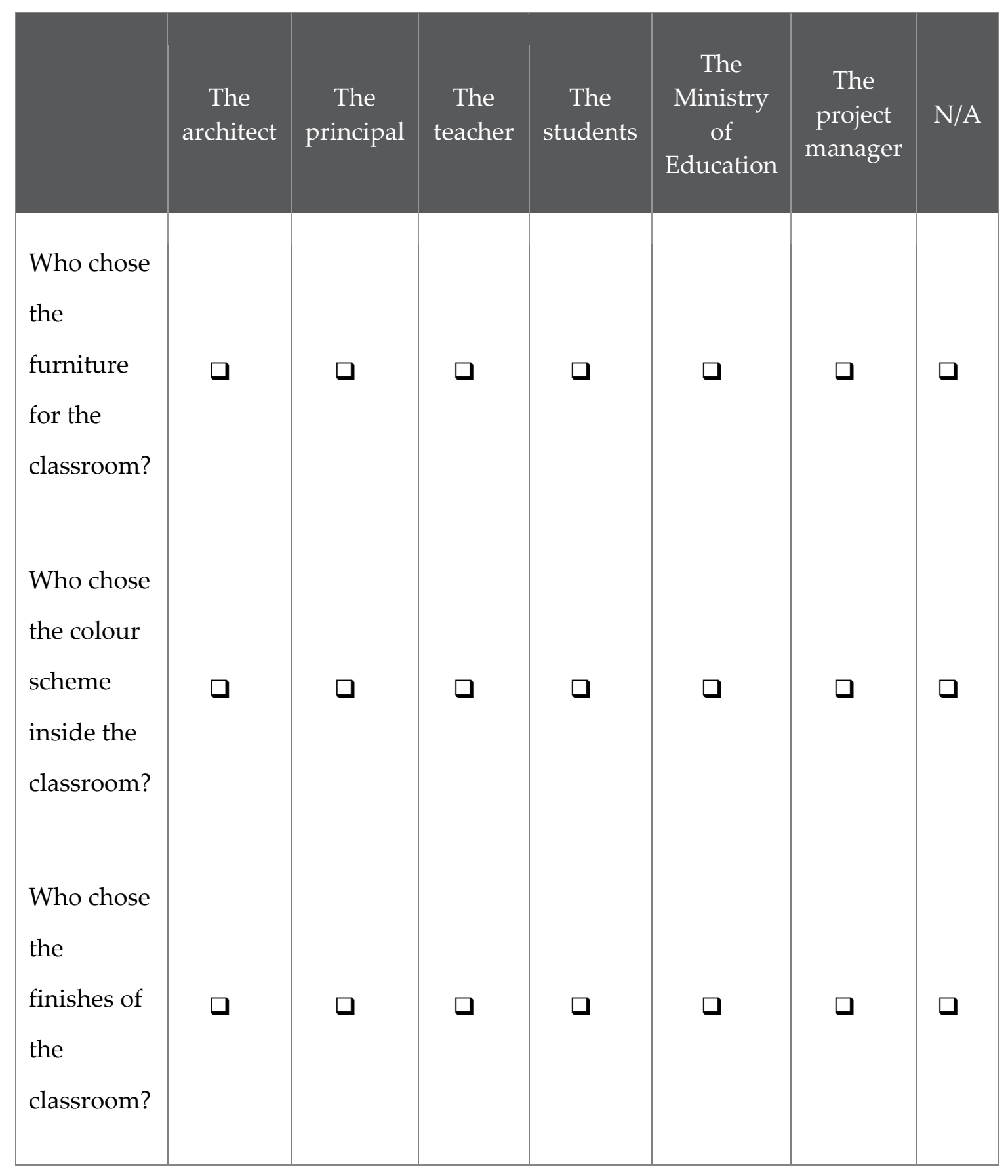




\begin{tabular}{|c|c|c|c|c|c|c|c|}
\hline $\begin{array}{l}\text { Who chose } \\
\text { the } \\
\text { location of } \\
\text { the fixtures } \\
\text { (eg. } \\
\text { sink/power } \\
\text { points) in } \\
\text { the } \\
\text { classroom? }\end{array}$ & 口 & 口 & $\square$ & $\square$ & 口 & a & $\square$ \\
\hline
\end{tabular}


Q11- Please agree or disagree with the following statements. 


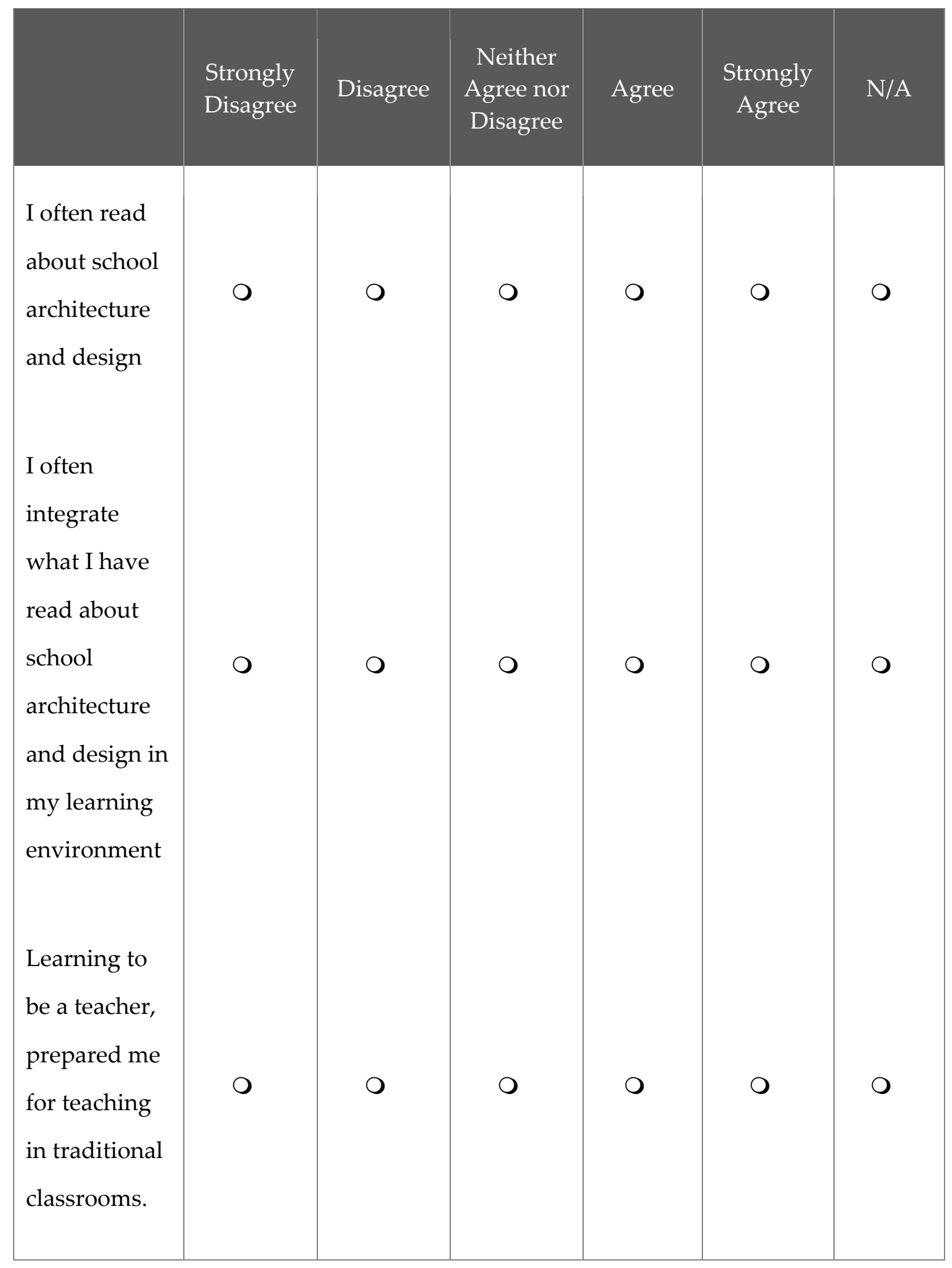




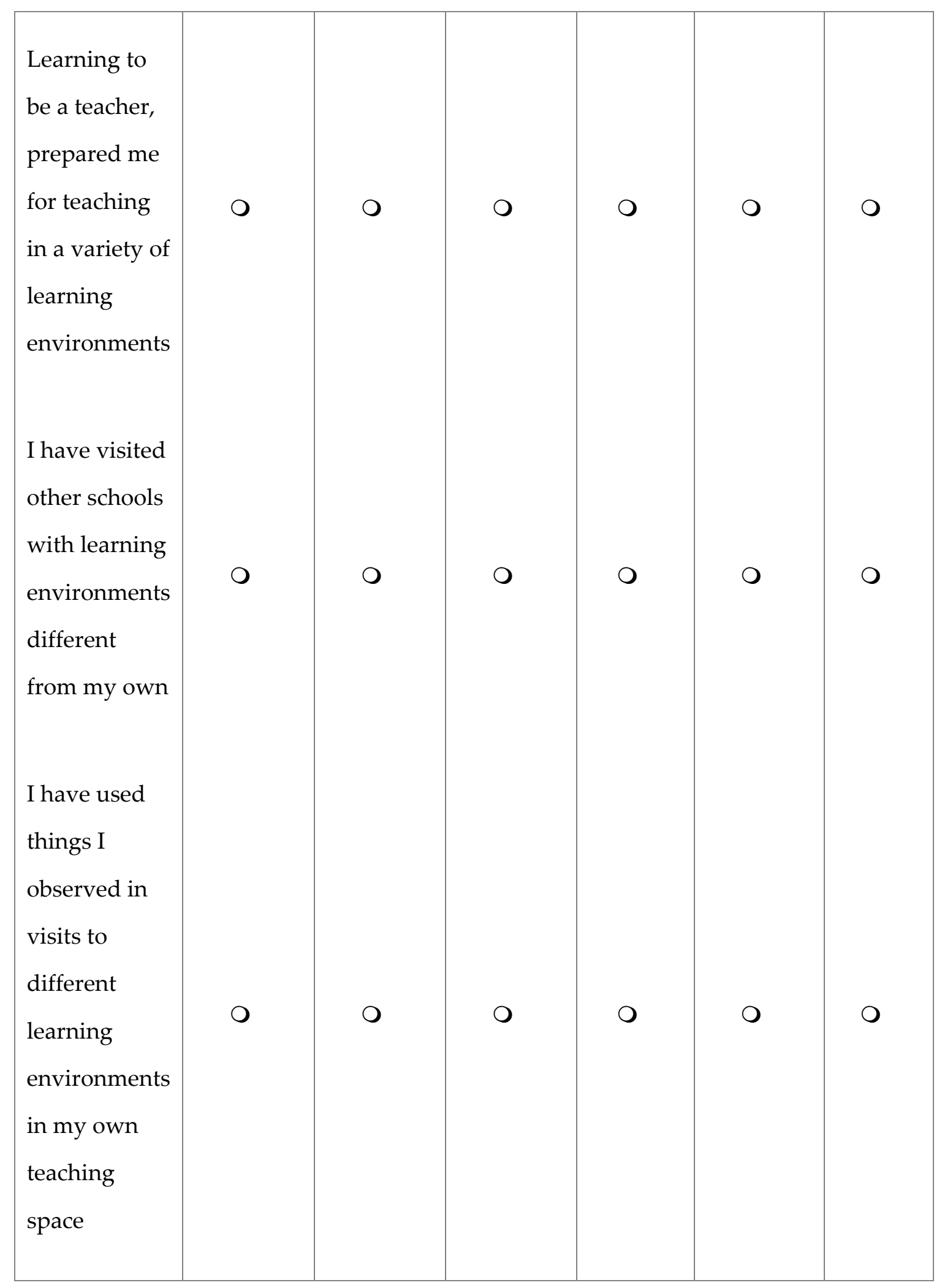


Q12- How frequently do you check the Ministry guidelines on classroom design (these talk about classroom furniture layout as well as aspects such as acoustics and natural lighting)?

O Never

O Occasionally

O Very Often

O I was unaware of the Ministry guidelines

\section{Existing Learning Environment}

Q13- Please tick as many of the following furniture and settings found in your current learning environment.

Desks/tables and chairs for all students

Group-work tables

- Some individual desks (not enough for all students to sit down at the same time)

Mat area

Beanbags

Shelves (including book shelves)

Sofa/s

Art area

D Drama corner (area for drama tools)

Music corner ( area for music playing and music instruments)

- Teacher's area

Computer area (including any IT equipment)

$\square$ Storage units

Indoor/outdoor access

$\square$ Other 
Q14- How satisfied are you with the current furniture layout?

O Very Dissatisfied

O Dissatisfied

O Somewhat Dissatisfied

O Neutral

O Somewhat Satisfied

O Satisfied

O Very Satisfied

Q15- How often do you make major changes to the furniture layout of your learning environment?

O Never

O Once a year

O Once a term

O More than once a term

O Daily

Please rank the following in terms of the things that most influence the layout of your learning environment, with 1 being the things that most influence the layout of your learning environment to 5 being the thing that least influence the layout of your learning environment. In the comments box please indicate any other things that influence your learning environment layouts. 
Q16- What are the things that most influence the layout of your learning environment?

The number of students

My teaching style

The furniture available

Doors and windows location

Room Fixtures location (e.g. sink and power points)

Comments 
Q17- Please agree or disagree with the following statements.

\begin{tabular}{|c|c|c|c|c|c|c|}
\hline & $\begin{array}{l}\text { Strongly } \\
\text { Disagree }\end{array}$ & Disagree & $\begin{array}{c}\text { Neither } \\
\text { Agree nor } \\
\text { Disagree }\end{array}$ & Agree & $\begin{array}{c}\text { Strongly } \\
\text { Agree }\end{array}$ & N/A \\
\hline $\begin{array}{l}\text { Students are } \\
\text { involved in } \\
\text { the } \\
\text { classroom } \\
\text { furniture } \\
\text { arrangement }\end{array}$ & $\mathrm{O}$ & $\mathrm{O}$ & $\mathrm{O}$ & O & $\mathrm{O}$ & $\mathrm{O}$ \\
\hline $\begin{array}{l}\text { The } \\
\text { furniture } \\
\text { layout } \\
\text { affects my } \\
\text { teaching } \\
\text { style }\end{array}$ & 0 & 0 & 0 & 0 & 0 & O \\
\hline $\begin{array}{l}\text { I have never } \\
\text { achieved my } \\
\text { ideal } \\
\text { furniture } \\
\text { layout in my } \\
\text { learning } \\
\text { space }\end{array}$ & 0 & 0 & 0 & 0 & 0 & O \\
\hline
\end{tabular}




\section{Ideal Layouts and the Design Process}

Q18- How would you improve your current furniture layout? Please rank the following in terms of what you most want to do, with 1 being the thing you most want to change to 6 being the thing you least want to change. In the comments box please indicate any other things you want to change in your learning environment.

Get rid of some furniture and not replace it

Replace some existing with new furniture

Change the furniture arrangement

Create more activity corners (eg. music corner, art corner)

Request a bigger space

Add indoor/outdoor access

\section{Comments}

Q19- How would you like to participate in the design process? Please rank the following statements with 1 being the most important for you and 7 the least 
important for you. Please add any other important issues for you in the comments box below.

I would like to be asked about the type of furniture my learning environment needs

I would like to be asked about the best location of the doors and windows

I would like to be asked about the fixtures in my learning environment (eg.

Sink, power points)

I would like to be involved in the selection of colours and finishes for my learning environment

I would like to be consulted about the size of my learning environment

I would like to be consulted about the physical form of my learning environment (eg. open plan or single cell classroom)

I would like to be provided with good examples of learning environments

I would like my students to be involved in the design process 
Comments:

Q20- Please agree or disagree with the following statements.

\begin{tabular}{|c|c|c|c|c|c|c|}
\hline & $\begin{array}{l}\text { Strongly } \\
\text { Disagree }\end{array}$ & Disagree & $\begin{array}{l}\text { Neither } \\
\text { Agree nor } \\
\text { Disagree }\end{array}$ & Agree & $\begin{array}{c}\text { Strongly } \\
\text { Agree }\end{array}$ & N/A \\
\hline $\begin{array}{l}\text { Students } \\
\text { should be } \\
\text { involved } \\
\text { more in } \\
\text { the design } \\
\text { process }\end{array}$ & 0 & O & 0 & O & 0 & $\mathrm{O}$ \\
\hline $\begin{array}{l}\text { Teachers } \\
\text { should be } \\
\text { involved } \\
\text { more in } \\
\text { the design } \\
\text { process }\end{array}$ & 0 & 0 & 0 & 0 & 0 & $\mathrm{O}$ \\
\hline
\end{tabular}

A Future Student Exercise (this is introduced here in the hope you would like to participate in this, which is also part of the research, at a later date).

The aim of the exercise is to involve students in the study of and get their thoughts about classroom designs. The exercise is for students who are interested in participating. Some suggestions for the student exercise are as follows:

1) A brain storming session where the teacher introduces the aim of the study and this particular exercise. The aim is to get the students to think about 
how to design a classroom and its furniture layout, and the problems involved.

2) Discussion about the current design and furniture layout of the learning environment. This could include whether they like it or not. How they would improve it. How they would ideally like it to be.

3) Asking students to express their thoughts about their classroom and its layout in their favourite ways. They can create a short video or voice recording, draw a picture of their thoughts, write whatever they think, take photos of the classroom and comment on these, or produce an art project. They can also express their thoughts through activities other than those mentioned above (making a model). The work can be individual or in teams. When the work is complete, teachers can then upload it to the blog created for this part of the research. It will be necessary to take photos of the work if it is not in digital format, but this can also involve the students. The blog is a private space. Only teachers who are approved by me can post in this blog and see what others have posted.

Would you like to participate in the student exercise?

O Yes

O No

Please type your e-mail address below. You will receive an invitation email in addition to a tutorial presentation on how to register for the blog and post students work.

\section{E-mail}

\section{The Last Section}

Would you like to be involved further in this research about classroom design? The further research may include working with a teacher and students as well as 
architects in order to produce an improved design process for learning environments.

O Yes

O No

Please provide your contact details for the further studies.

Name

City

E-mail

Phone 


\section{Appendix E: Phase one Architects' Survey}

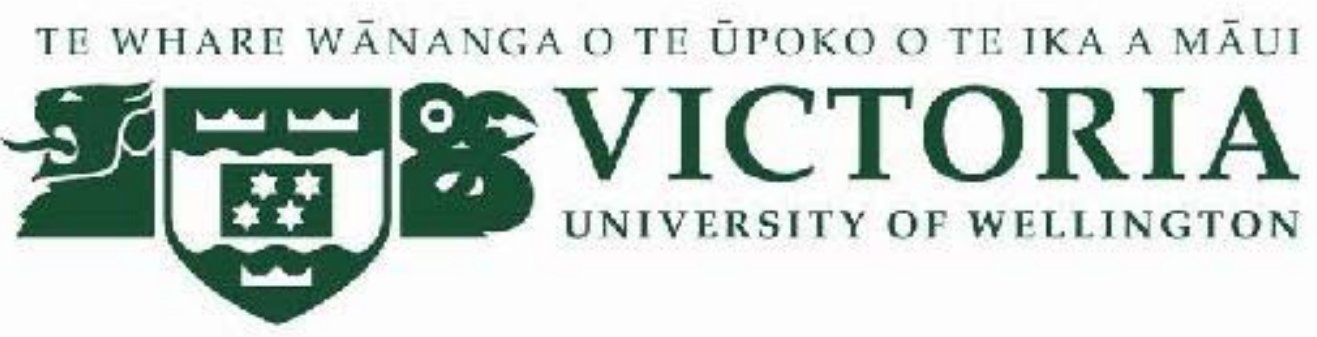

Information Letter for Professionals Questionnaire

My name is Fatimah Alsaif and I am a PhD candidate at School of Architecture, Victoria University of Wellington. The main objective of my research is to investigate the internal layouts in New Zealand primary school year 5/6 classrooms. This includes finding out whether the current layouts are sufficient or not, if there are problems in the furniture arrangements, and the reasons for these problems.

This information is about a self-administrated on-line questionnaire. The questionnaire is created according to the results of a focus group that was conducted with some designers. The main objective of the questionnaire is to collect information about the design process of classroom interiors and the internal layout of classrooms. Participants will answer a number of questions that takes about 15 minutes. The questions are in two sections; the first section includes 
questions about the different stages of the design process. The second section includes questions about post occupancy evaluations. The questionnaires are expected to be returned to the researcher within two weeks.

Should any participants feel the need to withdraw from the project, they may do so without question at any time before the data is analyzed. You may withdraw any time up to two weeks after I receive your response. Responses collected will form the basis of my research project and will be put into a written report on an anonymous basis. It will not be possible for you to be identified personally. All material collected will be kept confidential. No other person besides myself and my supervisors, Professor Brenda Vale and Christina Mackay, will see the questionnaires. A summary of the data analysis will be provided at your request, after the project is completed (2015).

The thesis will be deposited in the University Library. It is intended that one or more articles will be submitted for publication in scholarly journals. Questionnaires will be destroyed five years after the end of the project. If you have any questions or would like to receive further information about the project, please contact me at (alsaiffati@myvuw.ac.nz) or my supervisors, Professor Brenda Vale (brenda.vale@vuw.ac.nz) and Christina Mackay (christina.mackay@vuw.ac.nz), at the School of Architecture at Victoria University.

Thank you for your time

Fatimah Alsaif 


\section{Consent Form for Professionals Questionnaire}

Please read through the following and click "yes" at the end if you agree to take part in my research.

- I have been provided with adequate information relating to the nature and objectives of this research project, and have been given the opportunity to seek further clarification or explanations.

- I understand that I may withdraw from this study at any time before the final analysis of data without providing reasons.

- I understand that if I withdraw from the project, any data I have provided will be destroyed.

- I understand that any information I provide will be kept confidential to the researcher, and her supervisors, the published results will not use my name, and that no opinions will be attributed to me in any way that will identify me. I understand that the on-line questionnaire will be electronically wiped five years from the end of the project

- I understand that the information I have provided will only be used only for this research project in the ways described and that any further use will require my written consent.

According to the information provided, I agree to participate in this survey.

$$
\begin{aligned}
& \text { Yes } \\
& \text { No }
\end{aligned}
$$

If No Is Selected, Then Skip To End of Survey 
I would like to receive a summary of the results of this research when it is completed.

O Yes

O No

Please provide your e-mail address.

Thank you for choosing to participate in our survey. We value your opinion and honest feedback. The survey will take approximately 15 minutes and will be completely anonymous. Please click the " $>$ " button below to continue.

\section{General Questions}

Q1-What is the average number of staff working on your office?

O $1-6$

O 6-20

O More than 20

Q2-When was your last educational (school) project?

O We are currently working on a project

O 1-5 years ago

O 5-10 years ago

O More than 10 years ago 
Q3- Haw many primary school projects have you worked on? Please note any comments you have on your primary school commissioning in the box provided.

O None

Only one project

2-5 projects

More than 5 projects

If None Is Selected, Then Skip To End of Survey

Comments: 


\section{Designing Schools}

Q4- Please agree or disagree with the following statements. Again a box is provided for any comments you wish to make on the participatory design process.

\begin{tabular}{|c|c|c|c|c|c|c|}
\hline & $\begin{array}{l}\text { Strongly } \\
\text { disagree }\end{array}$ & Disagree & $\begin{array}{l}\text { Neither } \\
\text { agree nor } \\
\text { disagree }\end{array}$ & Agree & $\begin{array}{c}\text { Strongly } \\
\text { agree }\end{array}$ & N/A \\
\hline $\begin{array}{l}\text { a- } \\
\text { Working } \\
\text { with } \\
\text { teachers } \\
\text { improves } \\
\text { the quality } \\
\text { of school } \\
\text { design }\end{array}$ & 0 & 0 & 0 & 0 & 0 & $\mathrm{O}$ \\
\hline $\begin{array}{l}\text { b- } \\
\text { Working } \\
\text { with } \\
\text { children } \\
\text { improves } \\
\text { the quality } \\
\text { of school } \\
\text { design }\end{array}$ & 0 & O & 0 & 0 & 0 & 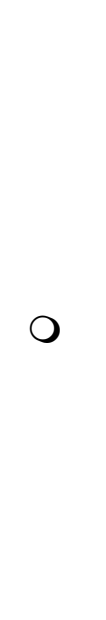 \\
\hline
\end{tabular}

\section{Comments:}


Q5 a- When designing a primary school foyer (reception), typically how many different furniture layouts do you try?

O None

O Only one layout

O More the one layout

O N/A

b- When designing a primary school library, typically how many different furniture layouts do you try?

O None

O Only one layout

O More the one layout

O N/A 
c- When designing a primary school hall, typically how many different furniture layouts do you try?

O None

O Only one layout

O More the one layout

O N/A

d-When designing a primary school office, typically how many different furniture layouts do you try?

O None

O Only one layout

O More the one layout

O N/A

e- When designing a primary school outdoor area, typically how many different furniture layouts do you try?

O None

O Only one layout

O More the one layout

O N/A

Q6- Please click as many boxes below as apply to your last primary school project. Again a box is provided below for comments. 


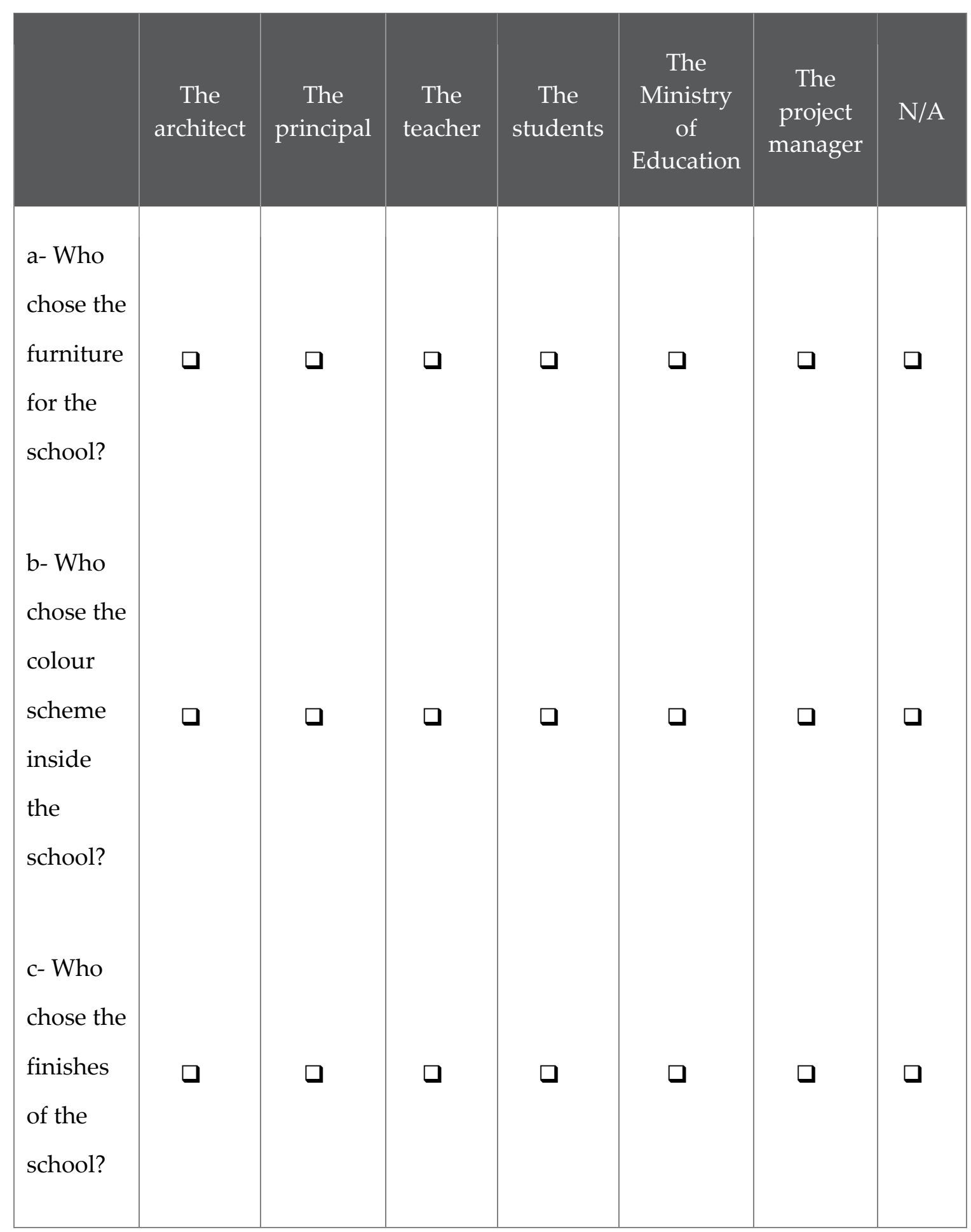

Comment:

\section{Designing Classrooms}

Q7- Please respond to the following statements. A box is provided for any comments you wish to make on the participatory design process. 


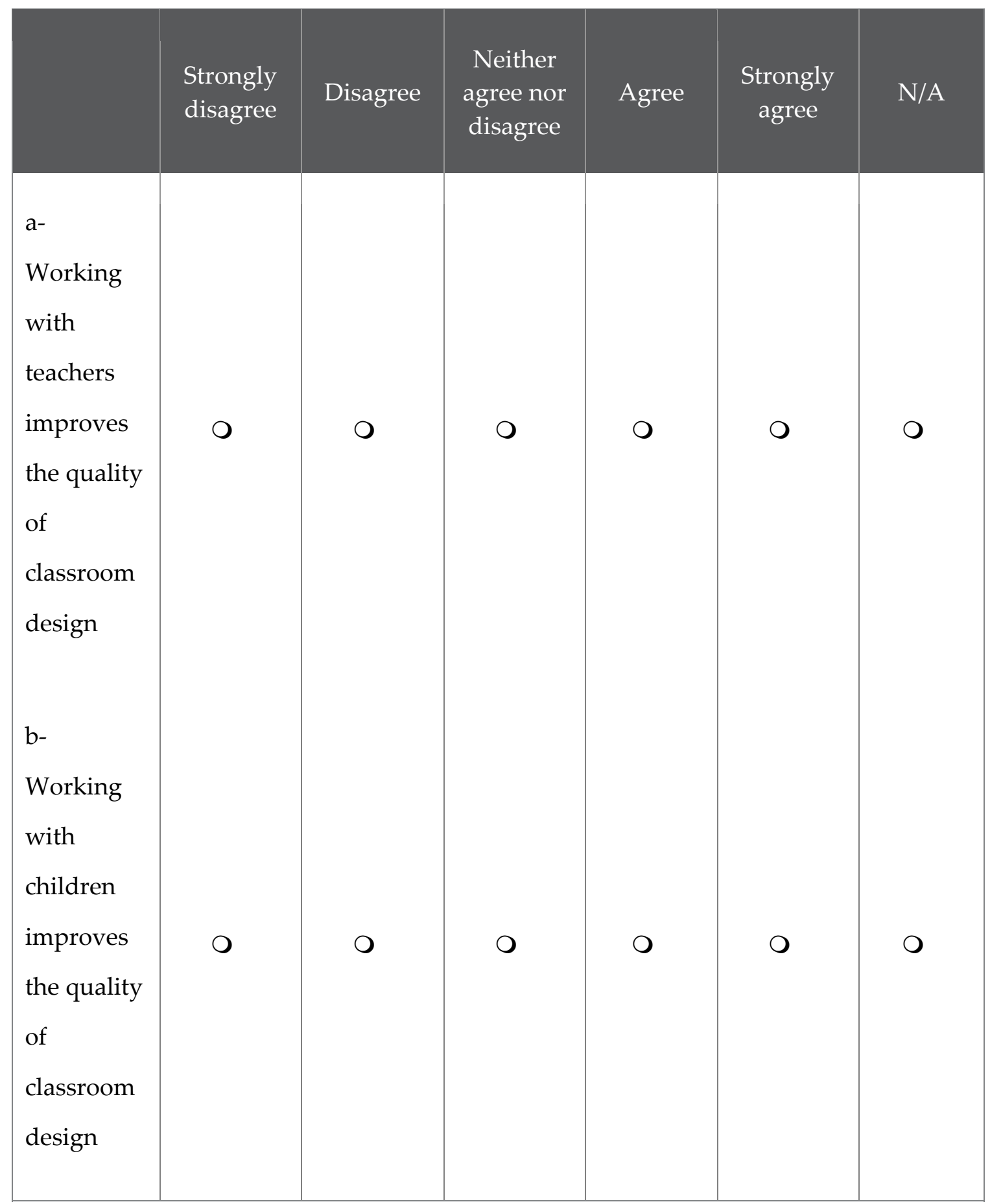

Comments:

Q8- When designing a classroom, typically how many different furniture layouts do you try?

O None

Only one layout

More the one layout 
O N/A

Q9- Please click as many boxes below as apply to your last primary school classroom project. Again a box is provided below for comments.

\begin{tabular}{|c|c|c|c|c|c|c|c|}
\hline & $\begin{array}{c}\text { The } \\
\text { architect }\end{array}$ & $\begin{array}{c}\text { The } \\
\text { principal }\end{array}$ & $\begin{array}{l}\text { The } \\
\text { teacher }\end{array}$ & $\begin{array}{c}\text { The } \\
\text { students }\end{array}$ & $\begin{array}{c}\text { The } \\
\text { Ministry } \\
\text { of } \\
\text { Education }\end{array}$ & $\begin{array}{c}\text { The } \\
\text { project } \\
\text { manager }\end{array}$ & $\mathrm{N} / \mathrm{A}$ \\
\hline $\begin{array}{l}\text { a- Who } \\
\text { chose the } \\
\text { furniture } \\
\text { for the } \\
\text { classroom? }\end{array}$ & 口 & व & 口 & 口 & 口 & ם & a \\
\hline $\begin{array}{l}\text { b- Who } \\
\text { chose the } \\
\text { colour } \\
\text { scheme } \\
\text { inside the } \\
\text { classroom? }\end{array}$ & व & ם & ם & व & व & ם & a \\
\hline $\begin{array}{l}\text { c- Who } \\
\text { chose the } \\
\text { finishes of } \\
\text { the } \\
\text { classroom? }\end{array}$ & व & ם & व & व & व & व & a \\
\hline
\end{tabular}

Comments: 


\section{Design Process in General}

Q10- Please agree or disagree with the following statements. A box is provided for any comments you wish to make on the participatory design process. 


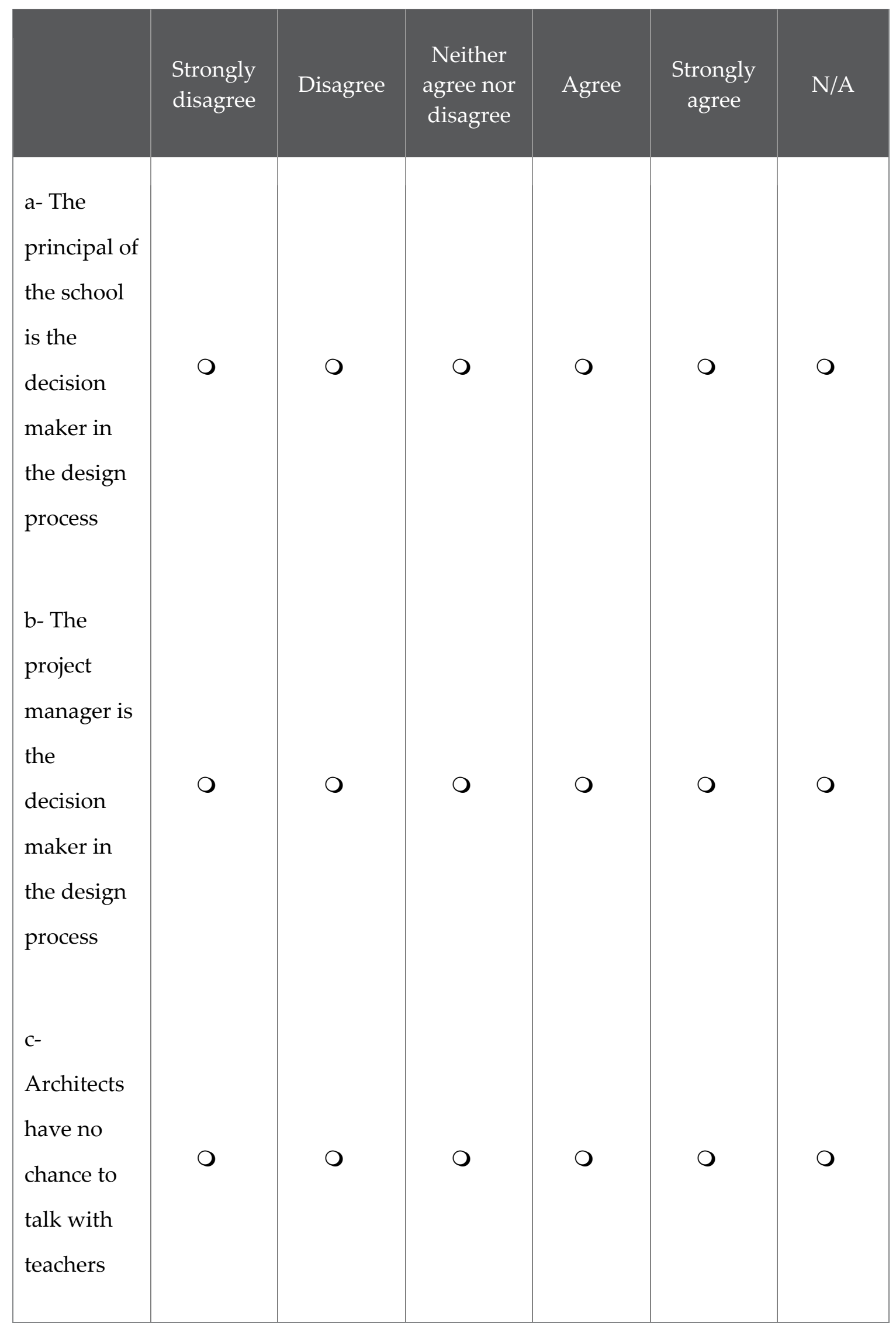




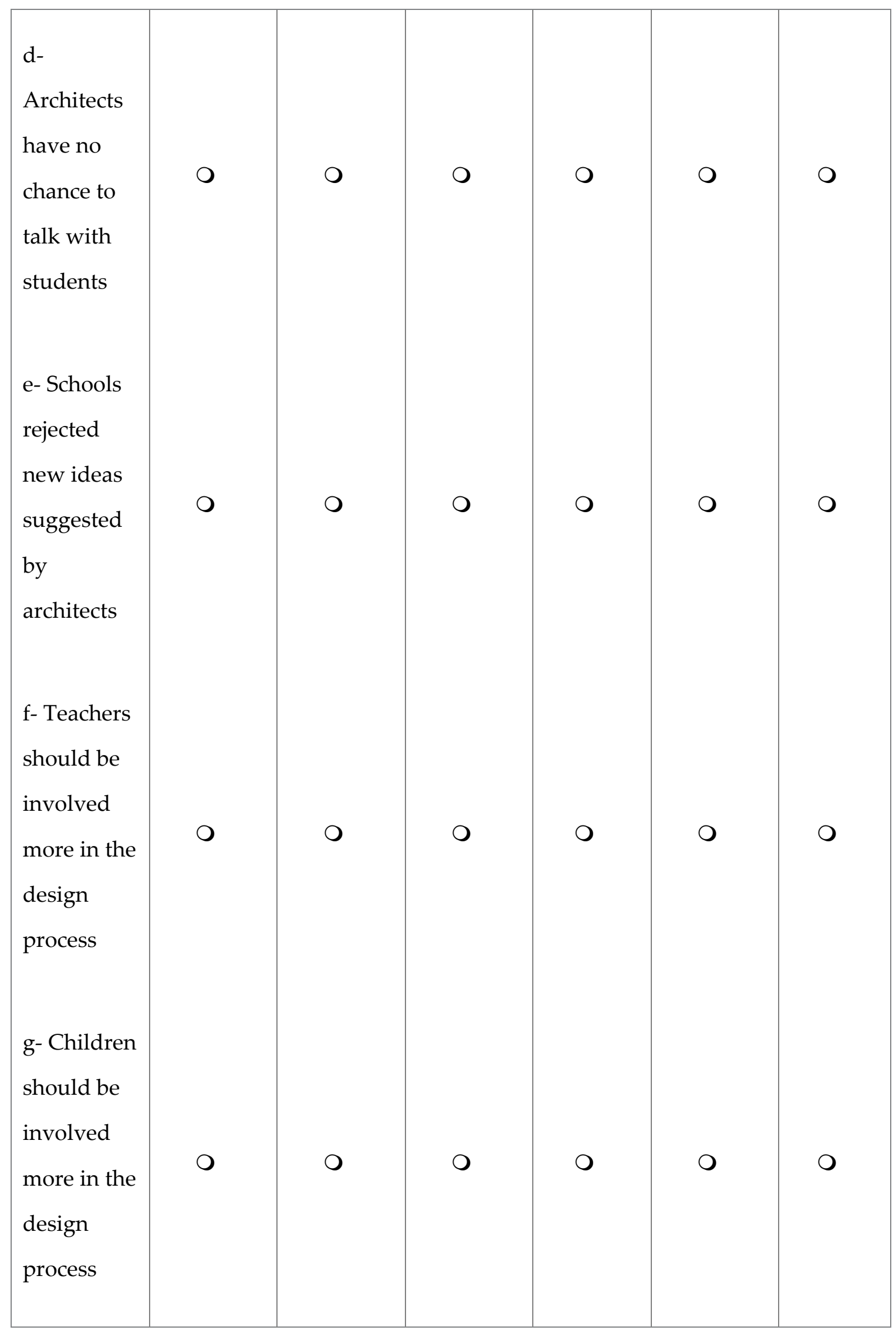




\begin{tabular}{|l|l|l|l|l|l|}
\hline h- The & & & & & \\
current & & & & & \\
structure of & & 0 & 0 & 0 & 0 \\
the deign & 0 & & & & \\
process for & & & & & \\
schools is & & & & & \\
totally & & & & \\
satisfactory & & & & \\
\hline
\end{tabular}

\section{Comments:}


Q11- What are the difficulties you face during the process of designing a school? (please tick as many boxes as you feel apply to your primary school design work)

Communicating with users

- Teachers or principals do not know much about architecture

Lack of time to do research

Dealing with the Ministry of Education

Lack of good school prototypes in New Zealand

Lack in money in the budget

Lack of access to design resources

$\square$ Other

Q12- How would you modify the current design process?

\section{Ministry of Education}

Q13- How frequently do you check the Ministry guidelines for classroom design?

O Never

O Occasionally

O Fairly often

O Very Often

O For every school project

If Never Is Selected, Then Skip To Q16

Q14- How satisfied are you with Ministry of Education guidelines?

O Very Dissatisfied

O Dissatisfied

O Somewhat Dissatisfied

O Neutral

O Somewhat Satisfied

O Satisfied

O Very Satisfied 
Q15- How could the guidelines be improved?

\section{Post Occupancy Evaluations}

Q16- Do you conduct post occupancy evaluations of your primary school work?

O Yes, formal evaluations

O Yes, but not formal

O Not at all

Q17- When you do a post occupancy evaluation, what are the things you observe that help you most in your new projects? (please rank the following items that apply where 1 is the most helpful)

Window treatments

Classroom finishes

Classroom colours

Classroom furniture layouts

Office area furniture layouts

School hall furniture layouts

Noise control

Temperature control

\section{Educational Books and Theories}

Q18- Please agree or disagree with the following statements. A box is provided for any comments you wish to make on educational theories. 


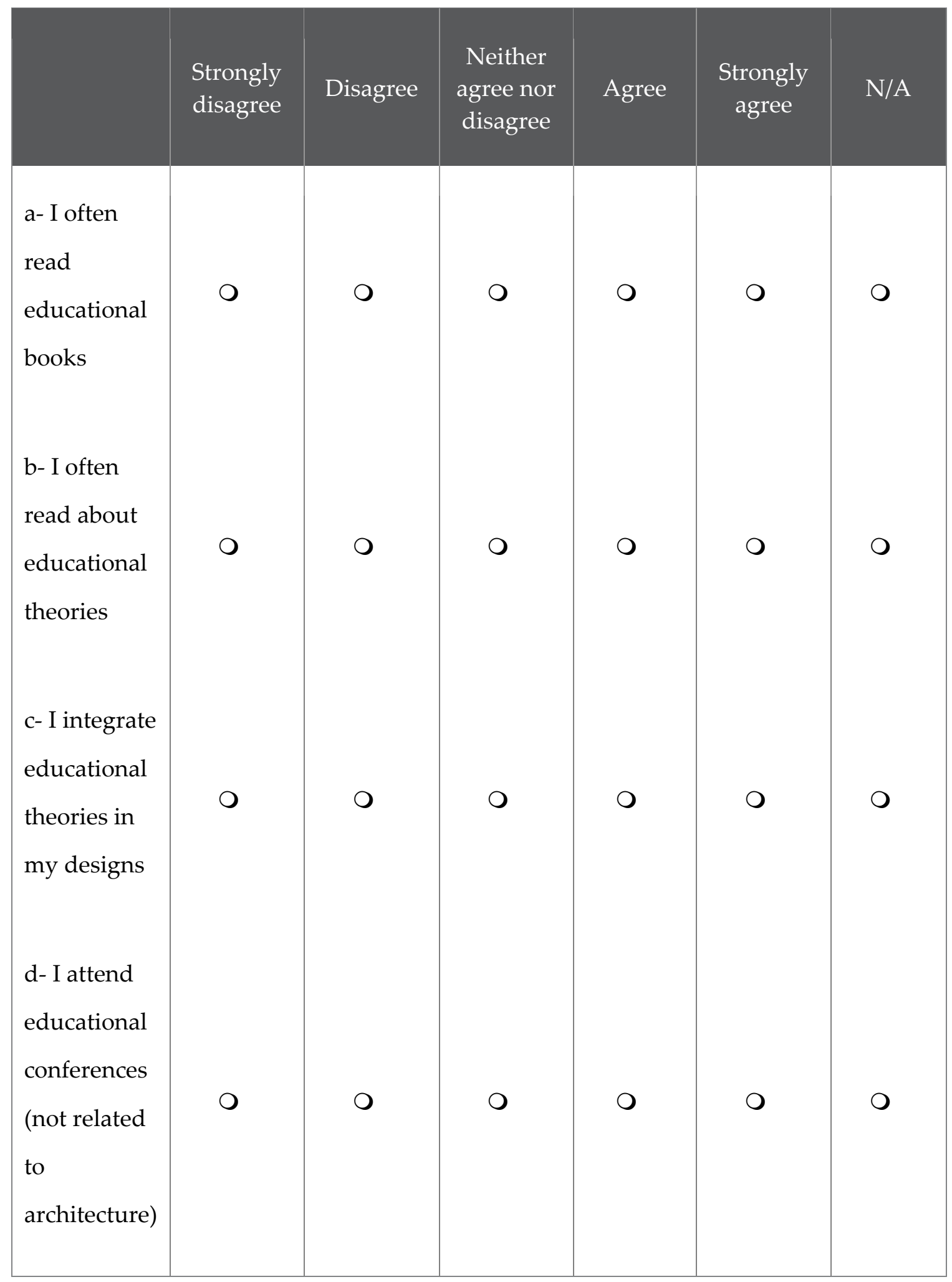

Comments:

Q19- Name one educational theory you have been inspired by (if applicable)

O 
O N/A

\section{The Last Section}

Would you like to share one of your primary school projects with this research?

O Yes

O No

Please upload photos and floor plans of one of your projects and send them to this e-mail: alsaiffati@myvuw.ac.nz

Would you like to be involved further in this research about classroom design?

O Yes

O No

Please provide your contact details for the further studies.

Name

City

Phone

E-mail 
APPENDIX F: PHASE THREE WORKSHOP FEEDBACK SHEET

I am $\square$ a teacher $\square$ an architect

Did the workshop give you new ideas or knowledge? If yes what were these?

Are you going to consider what happened in this workshop in your learning environments/ projects?

Do you thank that workshops are a good way of improving communication between architects and teachers? In what other ways could communication be improved?

Do you have any suggestions or comments on the workshop? 


\section{APPENDIX G: Phase FOUR QUESTIONS FOR THE}

\section{ARCHITECT}

The bold text is the researcher questions and non-bold the architect answers.

\section{- Who do you think the client is for this project?}

Formally the client is the Ministry of Education, who requires that we consult with the School.

However while the MoE are certainly the decision makers we take the view that our client is the Ministry, the School Board, the Principal and staff, the students, and the broader school community.

\section{- How many times have you met the teachers?}

Once to present initial thinking to the whole staff, a second time on a school visit to Amesbury School, and the staff were represented at our presentation of our masterplan. Senior staff also visited schools in Auckland with us, so we have had extensive opportunities to discuss our various thoughts

- Do you think that the current level of involvement of teachers is sufficient?

Yes, we know that the Principal is also reporting back to the staff.

Conversely it is important that we all understand that we are not just designing for that group of staff but for staff in years to come, irrespective of how compelling or strongly held some views may be.

- Have you asked for or discussed student involvement in this project? Yes, I know that the Principal is involving the students

- Do you think that teacher and student involvement is not important before getting into the details of the interior design of the school? 
No, I think that teacher and student involvement is important before getting into the interior design. Involvement means different things to different people though.

At this stage we are merely establishing the scope of the project. That in itself is far from settled. We have not really started designing the buildings, and we don't know yet how much we are designing.

- Teachers think that their voice is not necessarily considered in the design process. How do you feel about that? The design process has not yet really started, however we have heard from them as we have developed our masterplan thinking and their voice has been considered, and we have made decisions about site layouts which clearly reflect that. They are one of the many voices we need to consider.

- Do you have any plans to involve the users more in the rest of the design process?

Yes, an appropriate level of continuing dialogue will be established with the school as the design progresses. 
Appendix H: Phase five Questions for TEACHERS

- How do you and your students use the classroom?

- What have you done in terms of changing the furniture layout to suit you and your students?

- Have you completed any major furniture layout changes in this classroom? If yes how?

- Are any minor changes made in the classroom furniture layout during the school year? If yes, how often?

- Do you involve students in the minor or major changes in the classroom? If yes, how? 


\section{APPENDix I: PhASE FIVE BRAINSTORMING QUESTIONS}

- What is architecture?

- Who are architects?

- What are floor plans or layouts?

- What is a classroom?

- What do you do in a classroom?

- Who uses the classroom?

- What do you need inside a classroom?

- Do you need furniture in a classroom? Why?

- Close your eyes and imagine a classroom. What is the first thing you see in the classroom?

- What are the main areas that the classroom should contain? 


\section{APPENDix J: PHASE FIVE FEEDBACK SHEETS}

FEEDBACK SHEET (THORNDON CLASSROOM

TEACHER)

Name:

Before:

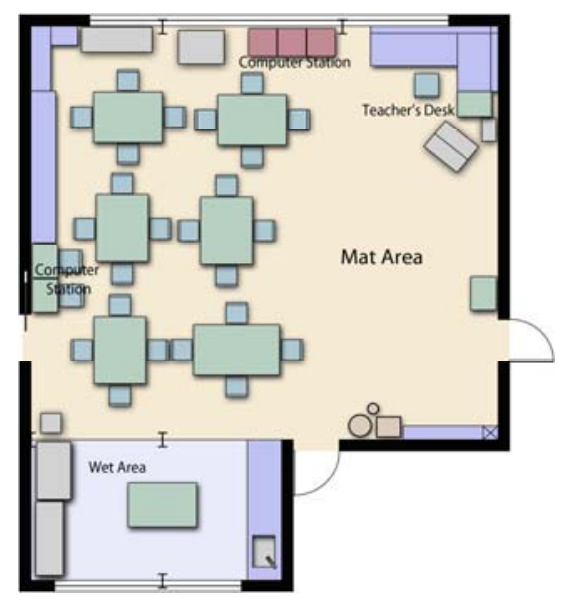

After:

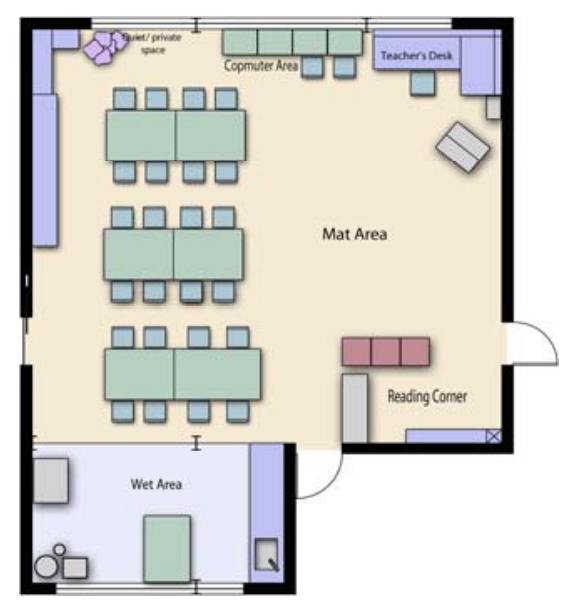

- What are the two things you like most in the new classroom layout?

- What are the two things you dislike most in the new classroom layout?

- Do you like the new classroom layout more than the old one? Yes No

- Are you going to keep the new layout?

Yes, with no changes.

Yes, with minor changes.

No

- You can write any other comments below. 
Name:

Before:

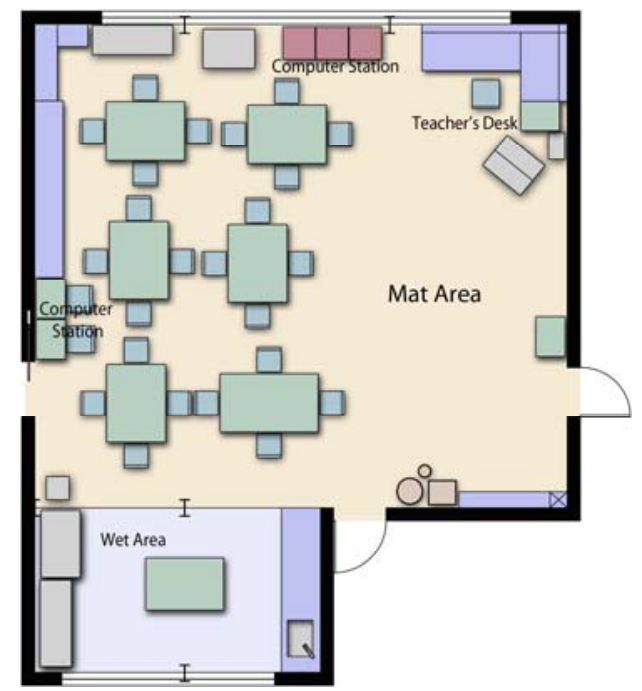

After:

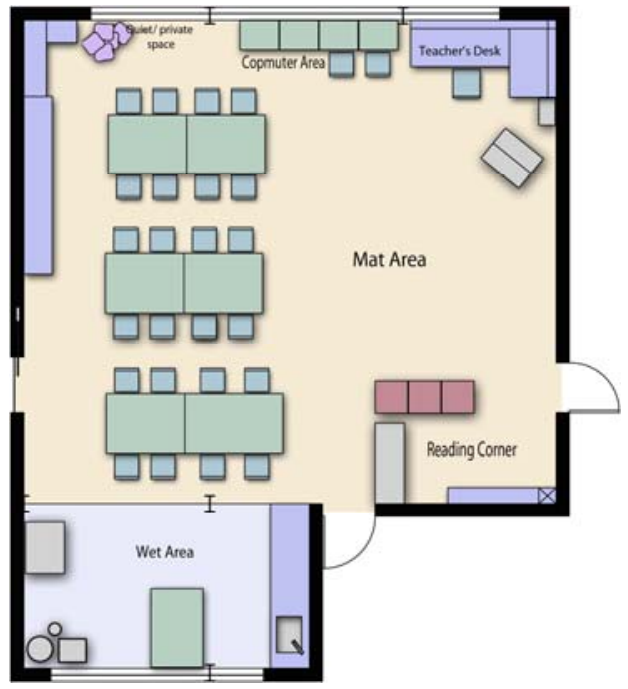

- What are the two things you like most in the new classroom layout?

- What are the two things you dislike most in the new classroom layout?

- Do you like the new classroom layout more than the old one? Yes No

- You can write any other comments below. 
TEACHER FEedback SheEt (TE Aro Classroom)

Name:

Before:

After:

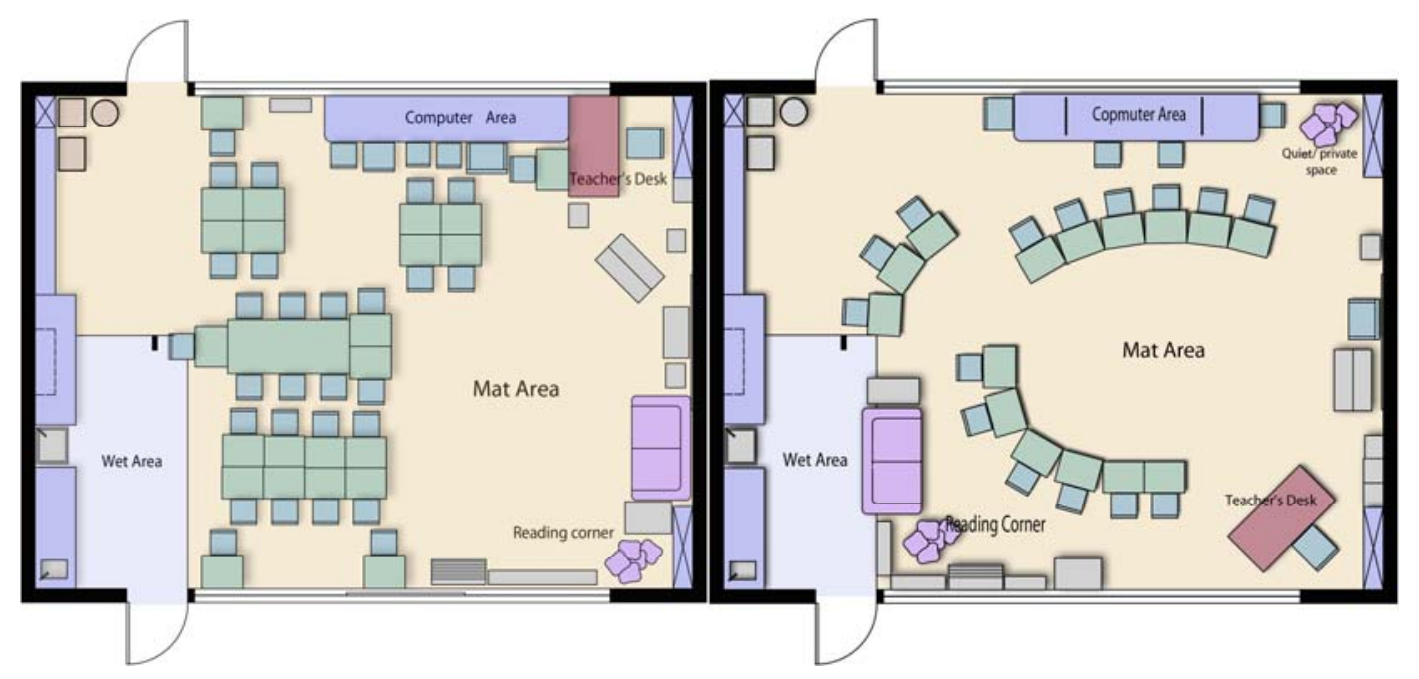

- What are the two things you like most in the new classroom layout?

- What are the two things you dislike most in the new classroom layout?

- Do you like the new classroom layout more than the old one? Yes No

- Are you going to keep the new layout?

Yes, with no changes.

Yes, with minor changes.

No

- You can write any other comments below. 
Name:

Before: After:

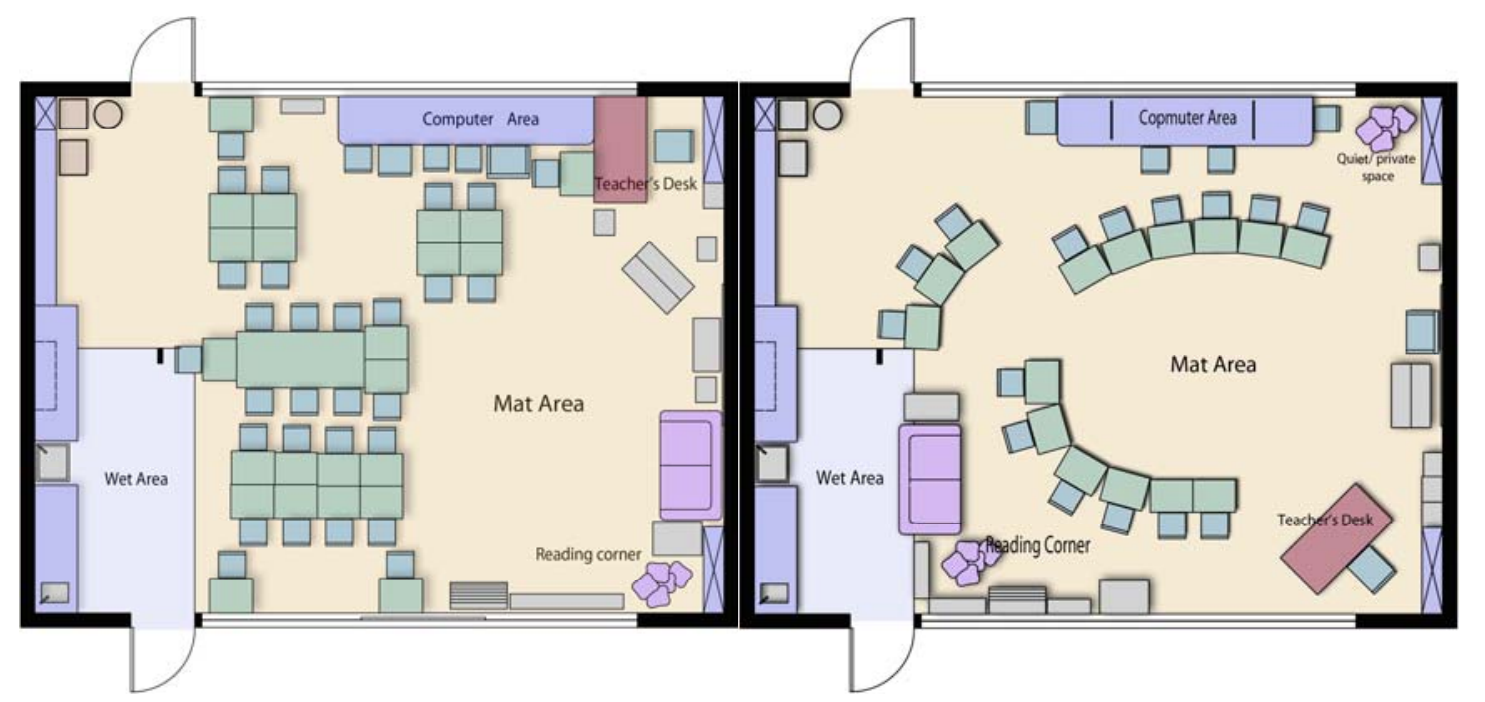

What are the two things you like most in the new classroom layout?

- What are the two things you dislike most in the new classroom layout?

- Do you like the new classroom layout more than the old one? Yes No

- You can write any other comments below. 